JORGE CAVALCANTI BOUCINHAS FILHO

\title{
TUTELA JUDICIAL E MOVIMENTOS GREVISTAS: UM ESTUDO SOBRE A ATUAÇÃO DOS ÓRGÃOS DO PODER JUDICIÁRIO DIANTE DAS NOVAS FORMAS DE MANIFESTAÇÃO COLETIVA DOS OPERÁRIOS
}

Versão corrigida em 10 de maio de 2012. A original, em formato eletrônico (PDF), encontra-se disponível na CPG da unidade.

Tese de doutorado

Orientador: Professor Associado Antonio Rodrigues de Freitas Júnior.

UNIVERSIDADE DE SÃO PAULO

FACULDADE DE DIREITO

São Paulo-SP

2012 
JORGE CAVALCANTI BOUCINHAS FILHO

\section{TUTELA JUDICIAL E MOVIMENTOS GREVISTAS: UM ESTUDO SOBRE A ATUAÇÃO DOS ÓRGÃOS DO PODER JUDICIÁRIO DIANTE DAS NOVAS FORMAS DE MANIFESTAÇÃO COLETIVA DOS OPERÁRIOS}

\footnotetext{
Tese de doutorado apresentada ao Programa de Pós-Graduação em Direito da Universidade de São Paulo - como requisito para obtenção do título de doutor em Direito do Trabalho, sob a orientação do Professor Associado Antonio Rodrigues de Freitas Júnior.

Versão corrigida em 10 de maio de 2012. A original, em formato eletrônico (PDF), encontra-se disponível na CPG da unidade.
} 


\section{São Paulo}

2012

À Ilane Boucinhas, presença constante e indispensável, apesar de toda a distância geográfica que nos separa.

À Aida Dias, fonte inesgotável de força, de inspiração e de amor e à Maria Luisa Cavalcanti Soares (in memoriam), exemplo de retidão, elegância e serenidade.

À Marina e à Angélica Boucinhas, as melhores irmãs que alguém poderia desejar. 


\section{AGRADECIMENTOS}

Ao Professor Antonio Rodrigues de Freitas Júnior, pela ajuda e compreensão durante os momentos difíceis, pelo incentivo e confiança em mim depositados e pelo privilégio da amizade.

Ao Professor Augustin Émane, da Universidade de Nantes, pela fraternal acolhida e pelo indispensável apoio durante as pesquisas em solo francês.

Ao amigo Daniel Tolentino pela ajuda com levantamento de material bibliográfico em língua espanhola e ao amigo Gilberto Maistro Júnior pela ajuda na revisão do trabalho.

Aos Professores Homero Batista Mateus da Silva e Ronaldo Lima dos Santos, pelas valiosas e imprescindíveis ponderações feitas por ocasião do exame de qualificação.

Aos Professores Otávio Pinto e Silva, Lucylla Telez Merino e Marcos Neves Fava pelas contribuições apresentadas no exame final.

À Ilane Boucinhas, que não é apenas a melhor mãe do mundo, é a melhor pessoa que conheço.

À Marina, Angélica, Aida, Jorge, Rafael e Luiz César, pela alegria de tê-los em minha vida. 
La Huelga nos enseña a oponernos a la sumisión como regla de comportamiento social y permite enseñar a su vez el orgullo - y la fuerza - de la negación de lo existente para afirmar algo distinto, un escenario alternativo que contradice el actual. La huelga es un acto coral, un clamor que crece y es capaz de romper el recinto que protege el privilegio económico y la desigualdad.

\section{Antonio Baylos Grau}


LISTA DE ABREVIATURAS E SIGLAS

\begin{tabular}{|l|l|}
\hline CGT & Confédération générale du travail \\
\hline CIT & Conferência Internacional do Trabalho \\
\hline CLT & Consolidação das Leis do Trabalho \\
\hline ITF & International Transport workers Federation \\
\hline FSU & Unitarian Trade Union Federation of Ardèche \\
\hline OIT & Organização Internacional do Trabalho \\
\hline PM & Polícia Militar \\
\hline STF & Supremo Tribunal Federal \\
\hline TST & Tribunal Superior do Trabalho \\
\hline
\end{tabular}




\section{RESUMO}

Os movimentos grevistas sofreram o impacto das recentes modificações tecnológicas, da globalização e da terceirização. Antigas estratégias utilizadas pelos trabalhadores para pressionar seus empregadores já não produzem o mesmo efeito que outrora. Novas formas de manifestação estão surgindo o que, naturalmente, provoca novas formas de contraofensiva dos empregadores. O conceito legal de greve já não se mostra adequado, requerendo certo esforço hermenêutico para que os novos movimentos paredistas não sejam considerados irregulares. Além de estudar estas transformações, o presente trabalho se dedica a refletir sobre a postura dos órgãos do Poder Judiciário nesse novo contexto. Após pesquisa dogmático teórica em fontes legais, releitura de textos doutrinários e estudo de precedentes judiciais e de organismos internacionais, concluiu-se que os órgãos judiciais devem apresentar uma atuação voltada a assegurar o exercício do direito de greve. Sugeriu-se, para tanto, que, em caso de dúvida, seja sempre adotada a exegese que assegure a realização das manifestações.

PALAVRAS-CHAVE: greve; globalização; terceirização 


\begin{abstract}
The strike movements have suffered the impact of recent technological changes, globalization and outsourcing. Old strategies used by workers to pressure their employers no longer produce the same effect as before. New forms of workers manifestations are emerging which, of course, provokes new forms of counter-offensive of the employers. The legal concept of a strike is no longer adequate, requiring some hermeneutic effort to recognize the validity of the new kinds of strike movements. In addition to studying these transformations, the present work is dedicated to reflect on the position of the Brazilian Labor Justice in this new context. After a theoretical dogmatic research in legal sources and after reading doctrinal texts and judicial precedents and precedents of international agencies, the conclusion found is that the courts should have an action aimed at ensuring the right to strike. To achieve this goal, the courts should, in case of doubt, adopt an exegesis that assures work stoppage.
\end{abstract}

KEY-WORDS: strike; globalization; outsorcing 


\section{RÉSUMÉ}

Les mouvements de grève ont subi l'impact des récents changements technologiques, de la mondialisation et de l'externalisation. Les anciennes stratégies utilisées par les travailleurs pour faire pression sur leurs employeurs ne produisent plus le même effet que précédemment. De nouvelles formes d'expression émergent qui, bien sûr, provoque de nouvelles formes de contre-offensive du patronat. Le concept de la grève donné pour la loi n'est pas appopprié, non plus. Il fault un certain effort herméneutique afin que les nouveaux mouvements soient considérés comme valides. En plus d'étudier ces transformations, le présent travail est consacré à une réflexion sur la position des organes du pouvoir judiciaire dans ce nouveau contexte. Après des recherches dans les sources légales, la lecture de textes doctrinaux et des précédents judiciaires et des précédents des organismes internationaux, la recherché a conclu que les tribunaux doivent avoir une action visant à garantir le droit de grève. Il a été suggéré une exégèse toujours orientée pour assurer le droit de faire la grève.

MOTS-CLÉ: grève; mondialisation; externalisation 


\section{SUMÁRIO}

INTRODUÇÃO

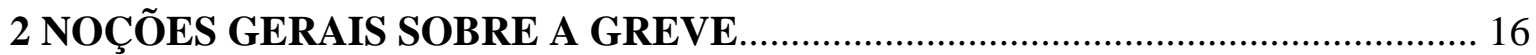

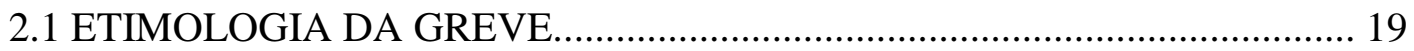

2.2 CONCEITO DE GREVE ............................................................................. 23

2.3 ASPECTOS HISTÓRICOS DO DIREITO DE GREVE................................. 33

2.4 ASPECTOS HISTÓRICOS DO DIREITO DE GREVE NO BRASIL ............ 44

2.5 DIREITO DE GREVE EM ALGUMAS EXPERIÊNCIAS

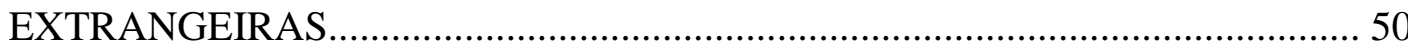

2.6 NATUREZA DO DIREITO DE GREVE.................................................... 58

2.7 TITULARIDADE DO DIREITO DE GREVE................................................... 63

2.8 O COMITÊ DE LIBERDADE SINDICAL DA OIT E O DIREITO DE

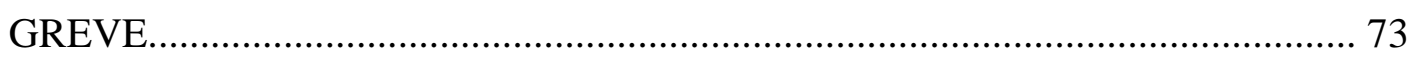

2.8.1. O direito de greve no Brasil sob a perspectiva do Comitê de Liberdade Sindical da OIT ....................................................................... 79

2.8.2 Reflexão sobre o atual entendimento do Comitê de Liberdade Sindical

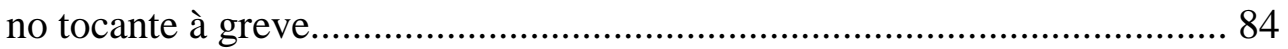

2.9 LIMITAÇÕES AO DIREITO DE GREVE................................................ 88

2.9.1 Limitação ao direito de greve relacionada com a essencialidade da atividade 92

2.9.2 Limitação ao direito de greve resultante de colisão com outros direitos fundamentais 96

2.9.3 Balizamento entre o direito de greve e outros direitos fundamentais 102

2.9.4 Limitação ao direito de greve baseada no motivo da deflagração

2.9.5 O direito de greve e a imposição de procedimentos prévios 122

2.9.6 Situações em que não se permite movimento grevista 130

3 NOVA FEIÇÃO DA GREVE.

3.1 GLOBALIZAÇÃO E MOVIMENTO GREVISTA. 135

3.2 TERCEIRIZAÇAO E MOVIMENTOS GREVISTAS. 139

3.3 REVOLUÇÃO TECNOLÓGICA E MOVIMENTOS PAREDISTAS 143 
3.4 PRIMAZIA DA PREOCUPAÇÃO COM O CONSUMIDOR 146

3.5 MEIOS COLETIVOS DE PRESSÃO DOS TRABALHADORES E SUA VALIDADE JURÍDICA.

3.6 LICITUDE DAS GREVES ATÍPICAS E DOS OUTROS MEIOS DE LUTA

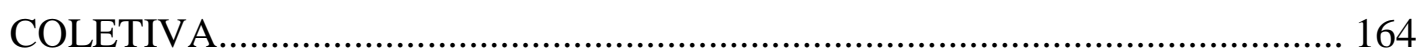

3.7 MEIOS COLETIVOS DE PRESSÃO DOS EMPREGADORES....................172

3.8 GARANTIAS AO EXECÍCIO DO DIREITO DE GREVE.......................... 174

4 A TUTELA PREVENTIVA E SUAS LIMITAÇÕES ......................................... 180

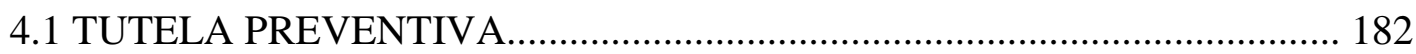

4.2 TUTELA INIBITÓRIA NO PROCESSO DO TRABALHO......................... 185

4.3 INADMISSIBILIDADE DE TUTELA PREVENTIVA................................187

5 AÇÕES RELACIONADAS COM O EXERCÍCIO DA GREVE..............................193

5.1 EXEMPLOS DE EXCESSIVA INTERVENÇÃO DO JUDICIÁRIO NAS MANIFESTAÇÕES GREVISTAS.................................................................. 203

5.2 INTERDITOS PROIBITÓRIOS............................................................... 215

5.2.1. Competência material e hierárquica................................................ 216

5.2.2 Legitimidade do sindicato para figurar no pólo passivo dos interditos proibitórios 219

5.2.3 Movimentos paredistas e violação e ameaça à posse do empregador.

5.2.4 Dificuldades na caracterização do justo receio de dano à posse e na verificação de provas aptas à concessão do interdito.................................. 225

5.2.5 Movimentos grevistas e violação ao direito de ir e vir...................... 232

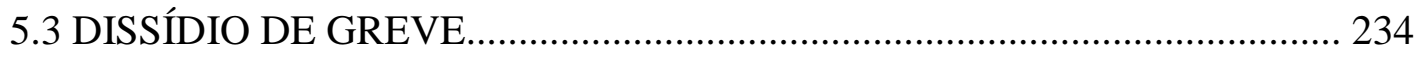

5.4 AÇÕES PREVENTIVAS VISANDO SAVALGUARDAR O DIREITO DE

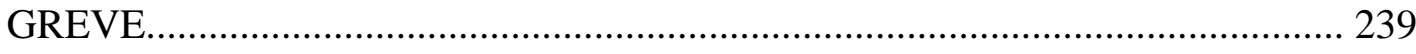

5.5 COGNIÇÃO JUDICIAL NAS AÇÕES DE DIREITO DE GREVE................ 242

5.6 RESPONSABILIDADE CIVIL DOS SINDICATOS PELO EXERCÍCIO ABUSIVO OU ILEGÍTIMO DO DIREITO DE GREVE................................... 250

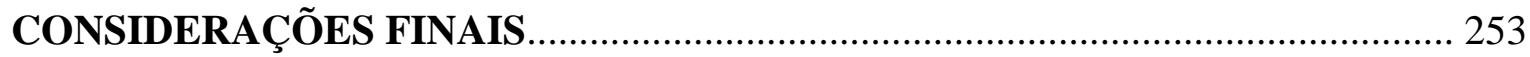

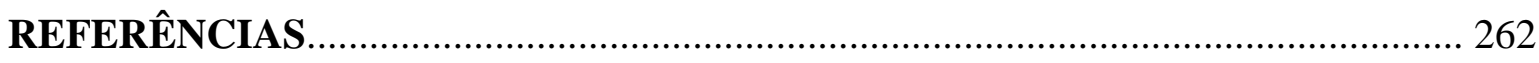

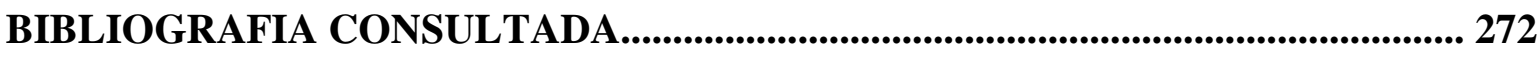




\section{INTRODUÇÃO}

O avanço tecnológico, a globalização e diversas mudanças sócio-econômicas vêm impactando a ação sindical de um modo geral e, de uma forma particularmente preocupante, o exercício do direito de greve. A relação de competitividade imposta pelo mercado global justificou uma radical modificação na forma de pensar a doutrina que sustentava o estado do bem-estar social e as garantias dos trabalhadores em todo o sistema ocidental. Fenômenos como a terceirização de mão-de-obra, a adoção do conceito de fábrica flexível e a maior facilidade na migração de pessoas reduziram consideravelmente o poder de reivindicação dos trabalhadores em face de seus empregadores. $\mathrm{O}$ enfraquecimento do movimento sindical limitou, em muitos setores, o recurso à greve a uma hipótese residual. Em determinadas atividades econômicas, a simples paralisação das atividades dos trabalhadores já não consegue pressionar o empregador como outrora.

As pessoas físicas se apresentam hipossuficientes em relação às grandes corporações, tanto quando investidos na condição de trabalhador quanto quando assumem as vestes de consumidor. O ponto de divergência entre as duas personas, quando reunidas na mesma pessoa, se verifica no momento em que a opção do trabalhador por exercer o seu direito de greve prejudica os interesses do consumidor, situação verificada, por exemplo, quando o empregador-fornecedor repassa para o consumidor, por meio do aumento nos preços, o prejuízo causado por uma paralisação prolongada. É o que ocorre também quando empregados de determinada categoria econômica, ao se sentirem prejudicados pela paralisação de trabalhadores de outra categoria, em especial a daqueles ligados aos serviços essenciais, ao invés de solidarizarem com estes, aderem ao coro do empregador em prol da cessação do movimento paredista. Em outras palavras, optam por entrar nas vestes de consumidor e não nas de trabalhador. 
A sobreposição dos direitos do consumidor aos do trabalhador vem sendo expressamente destacada em obras doutrinárias e em decisões judiciais.

O presente estudo consiste em uma apologia à fundamentalidade dos movimentos paredistas, um ensaio em favor da valorização do direito de greve em um mundo onde o trabalhador quando ingressa em uma loja para comprar o produto que ajudou a elaborar recebe melhor tratamento e maior proteção legal e judiciária do que quando trabalhava no processo de manufatura do mesmo item. Propõe-se aqui uma releitura deste direito em um momento histórico em que nitidamente prevalece à máxima segundo a qual "o cliente tem sempre razão".

Também se analisa neste estudo o impacto que as modificações de cunho tecnológico, político e sócio-econômico verificadas a partir das últimas décadas do século passado têm provocado na ação dos sindicatos durante os movimentos paredistas. Percebendo que a simples paralisação das atividades laborais dos integrantes da categoria não consegue pressionar o empregador a atender suas reivindicações por não resultar na cessação das atividades de determinadas empresas, alguns sindicatos têm buscado, durante o curso do movimento grevista, outras formas de ação coletiva. Tem sido cada vez mais frequentes a realização de piquetes objetivando não apenas provocar a adesão de empregados à paralisação, mas também impedir o acesso de clientes (consumidores) e de não grevistas ao estabelecimento com o intuito de paralisar toda a sua atividade. Novas estratégias vêm sendo utilizadas com o mesmo fim como, por exemplo, o besuntamento da entrada dos locais de trabalho, para impedir o acesso de clientes e não-grevistas, a contratação de piquetistas "terceirizados", para evitar represálias posteriores aos trabalhadores que aderirem à greve de forma mais exaltada, entre outras.

Referidas táticas provocam alegações de colisão entre o direito de greve e outros direitos fundamentais. Afirma-se serem elas formas de coação para que os trabalhadores adiram involuntariamente à greve e de impedir o direito de ir e vir dos clientes. Essas assertivas são questionáveis e sobre elas se refletirá no momento oportuno. Cabe, em particular, questionar se, sob a ótica atual, estas medidas não seriam a única forma de as entidades sindicais conseguirem pressionar os empregadores em busca de melhorias para a categoria profissional que representam e se esta circunstância não justificaria, por si só, o reconhecimento da legitimidade dessas manifestações. O presente estudo tem como um de seus fins analisar como os órgãos que integram o judiciário trabalhista vem se pocionando 
diante destes alegados conflitos de direitos fundamentais e como se entende que eles deveriam se posicionar.

Decisões de grande repercussão vêm evidenciando uma excessiva intervenção do judiciário nos movimentos grevistas. Uma das que será estudada ao longo do trabalho encerrou a mobilização de aeronautas e aeroviários antes mesmo que a mobilização tivesse início, por considerar que a paralisação destas categorias às vésperas do período natalino de 2010 seria oportunista. Não observou, contudo, que a Constituição assegura aos trabalhadores o direito de greve garantindo-lhes ainda a prerrogativa de determinar a "oportunidade" de exercê-lo e de definir os interesses que por meio dele pretende defender.

A intervenção do judiciário na mobilização de aeronautas e aeroviários também evidenciou a necessidade de sistematização da intervenção judicial nos movimentos paredistas. A ação imediata de diferentes órgãos de defesa de interesses coletivos provocou decisões judiciais simultâneas e parcialmente divergentes da Justiça do Trabalho e também da Justiça Federal, demonstrando assim a possibilidade de litispendência, com todos os inconvenientes que ela pode causar, entre ações em que se defende interesses dos trabalhadores e dos consumidores.

Estas reflexões acerca dos limites da intervenção do judiciário nos movimentos grevistas se tornam ainda mais imprescindível em razão de os empregadores estarem, com freqüência cada vez maior, buscando socorro do judiciário para tentar evitar que movimentos grevistas impeçam o acesso livre dos trabalhadores chamados "fura-greve" e dos clientes aos seus estabelecimentos, ou que danifiquem o seu patrimônio.

O trabalho incorre em uma análise sobre as situações em que o poder judiciário é chamado a intervir nos movimentos grevistas, refletindo, de forma particular, sobre a possibilidade de tutela preventiva para a defesa de interesses dos empregadores e de terceiros e sobre a inadequação do instituto do interdito proibitório para o propósito que vem sendo utilizado.

Por fim, sendo certo que a própria Constituição autoriza a aplicação de sanções para os casos de exercício abusivo do direito de greve, urge refletir sobre a responsabilidade civil do sindicato e dos manifestantes pelos danos que causarem durante 
movimentos que não constituam efetivo exercício do direito de greve ou que, em o sendo, extrapolem seus limites. 


\section{NOÇÕES GERAIS SOBRE A GREVE}

Márcio Túlio Viana, com a percuciência que lhe é peculiar, destaca que desde os remotos tempos em que dormiam nas árvores, os homens juntam-se não só para a defesa, mas também para o ataque, como se, de fato, fossem lobos de si próprios. Observa ainda que essas lutas coletivas podem se voltar para a defesa do direito já posto, ou para a conquista de um novo direito ${ }^{1}$.

Foi dentro dessa perspectiva de união para preservação do direito já posto ou conquista de novos direitos que surgiu e vem se desenvolvento os movimentos grevistas.

Segundo Antonio Baylos Grau a greve é, antes de tudo, um processo de aprendizagem. De aprender a dizer não a um processo de privatização dos espaços públicos e das consciências pessoais, de dizer não ao esquecimento de muitos séculos de luta pela igualdade. A greve, em sua opinião, expressa a resistência cidadã a uma situação resignada de subordinação e de restrição paulatina de espaços livres para uma existência segura. Expressa a força do número de trabalhadores enquanto figuras subalternas nos processos econômicos e sociais frente à força que ostenta o poder econômico e que constitui o maior obstáculo à liberdade e igualdade dos cidadãos. A greve, segundo o festejado juslaboralista espanhol, nos ensina a nos opor à submissão como regra de comportamento social e permite mostrar, por sua vez, o orgulho - e a força - com a negação do que existe para afirmar algo distinto, um cenário alternativo que contradiz o atual. A greve, em seus

\footnotetext{
${ }^{1}$ VIANA, Márcio Túlio. Direito de resistência: possibilidades de autodefesa do empregado em face do empregador. São Paulo: LTr, 1996, p. 281.
} 
dizeres, "es un acto coral, un clamor que crece y es capaz de romper el recinto que protege el privilegio económico y la desigualdad",2.

A greve consiste, por todas essas razões, em um importantíssimo ato políticodemocrático. Em um momento de participação democrática dos cidadãos que, mediante sua iniciativa direta, demonstra sua decisão de manter um projeto igualitário que vá se completando no tempo. A greve, ainda segundo Baylos Grau, tem sido o instrumento mediante o qual se vem conseguindo a grande maioria dos direitos sociais, conceituados como direitos de cidadania plena ${ }^{3}$.

Em sentido convergente, Augusto César Leire de Carvalho afirma que, sob a perspectiva da teoria política, a greve faz emergir a importância do princípio democrático na medida em que, por meio dela, entrega-se a resolução do conflito coletivo à própria coletividade, pondo-se freio ao poder social que se estaria exercendo em rota de colisão com o ideal de uma sociedade livre, justa e solidária. Em sua opinião, “A ruptura da normalidade, no ambiente da empresa, serve para que ele se deixe contaminar pelo princípio maior da democracia, conjugando afinal liberdade e participação"4.

Enfatizando a imprescindibilidade de um adequado estudo sobre o direito de greve, Homero Batista Mateus da Silva observa que o instituto em questão conseguiu a proeza de ter passado de um delito para um fato meramente tolerado e, finalmente, para um direito constitucionalmente assegurado, tudo no curtíssimo espaço de duas ou três gerações ${ }^{5}$.

Trata-se seguramente de um dos mais paradoxais institutos do direito. Ele contraria a máxima de equidade segundo a qual "o direito de alguém termina onde começa o de outrem”, já que a sua essência é causar prejuízo à outra parte da relação e a terceiros como forma de tentar fazer prevalecer um interesse determinado.

A greve usualmente nasce a partir de um problema alocativo a cujo tratamento os sujeitos endereçam percepções diferentes quanto a mais justa decisão, para o caso. Em

\footnotetext{
${ }^{2}$ GRAU, Antonio Baylos. Estado Democrático de Derecho y amplio reconocimiento del derecho de huelga. Derecho laboral - Tomo LIV, n. 242, abril-junio 2011, p. 285.

${ }^{3}$ Idem, p. $285 / 286$.

${ }^{4}$ CARVALHO, Augusto Cesar Leire de. Direito fundamental de greve e interdito proibitório. In: ARRUDA, Kátia Magalhães; COSTA, Walmir Oliveira da (coordenadores). Direitos coletivos do trabalho na visão do TST: homenagem ao Ministro Rider Nogueira de Brito. São Paulo: LTr, 2011, p. 14.

5 SILVA, Homero Batista Mateus da. Curso de direito do trabalho aplicado, vol 7: direito coletivo do trabalho. Rio de janeiro: Elsevier, 2010, p.6.
} 
outras palavras, o instituto ora estudado enquadra-se dentro do conceito de conflito de justiça de Antonio Rodrigues de Freitas Júnior ${ }^{6}$. Paradoxalmente, entretanto, a greve também consiste, por si só, em um conflito, ou pelo menos na exteriorização de um preexistente, como preferem alguns. Ela consagra uma visão de que um conflito, usualmente uma figura combatida pelo direito, pode ser a forma de solucionar outro preexistente.

Esta visão de que o conflito em si pode ser funcional deriva, segundo Oscar Ermida Uriarte, da ideia de que ele é normal, ou é relativamente normal em uma sociedade pluralista, integrada por grupos sociais distintos. Em sua visão, os conflitos, e a greve entre eles, podem cumprir uma função equilibradora, restabelecedora de um equilíbrio alterado ${ }^{7}$.

Oscar Ermida Uriarte destaca que a autotutela ou tutela coletiva antecedeu à tutela individual sendo a responsável pela origem do Direito do Trabalho, durante o desenvolvimento da superexploração da mão de obra provocada pela revolução industrial. Diante desta situação, os trabalhadores se agrupam para opor ao poder do empregador a força do número (sindicato), pressionando em conjunto (greve) e acordando coletivamente a melhora de alguma das condições de trabalho (negociação coletiva) ${ }^{8}$. Formar-se-ia, outrossim, a estrutura triangular do direito coletivo do trabalho cujos três aspectos essenciais são justamente o sindicato, a negociação coletiva e a greve. A inexistência ou fragilidade de qualquer destes três pilares determina, em sua opinião, o mau funcionamento do direito coletivo do trabalho e, consequentemente, o cumprimento insuficiente ou o não da função de autotutela' .

Após afirmar ser a greve o meio de pressão facultado aos trabalhadores para forçar os empregadores ao atendimento de suas reivindicações, de forma que sem ela a negociação coletiva perderia muito de sua expressão, pois bastaria a recusa do empregador em negociar para frustrar as pretensões dos trabalhadores, sem maiores consequências, Otavio Pinto e Silva destaca que ambas figuras estão inseridas na Constituição da

\footnotetext{
${ }^{6}$ FREITAS JÚNIOR, Antonio Rodrigues de. Conflitos de justiça e direito do trabalho: alcance e possibilidades para o emprego da mediação. In: BOUCINHAS FILHO, Jorge Cavalcanti; PEREIRA, Luciano de Castilho e FAVA, Marcos Neves (org). O direito material e processual do trabalho dos novos tempos: estudos em homenagem ao Professor Estêvão Mallet. São Paulo: LTr, 2009, p. 55.

7 ERMIDA URIARTE, Oscar. Apuntes sobre la huelga. $2^{\mathrm{a}}$ ed. Fundación de cultura universitária. Montevideo: 1996, p. 14.

${ }^{8}$ ERMIDA URIARTE, Oscar. Critica de la libertad sindical. Derecho Laboral - Tomo IV, n. 242, abril-junio 2011, p. 225.

${ }^{9}$ ERMIDA URIARTE, Oscar. Apuntes... op. cit., p. 9/10.
} 
República Federativa do Brasil como direitos coletivos do trabalho ${ }^{10}$. O terceiro pilar deste subramo do direito laboral estaria consagrado nos diversos incisos do artigo $8^{\circ}$ da Carta Magna.

Percebe-se, desta forma, a essencialidade da autotutela coletiva na origem do direito do trabalho, no seu funcionamento como ordenamento protetor e na persecução de seus objetivos de igualização. Não sem razão Homero Batista Mateus da Silva considera a greve um dos alicerces sobre os quais se assenta a autonomia dogmática do direito do trabalho $^{11}$.

Jorge Luiz Souto Maior, por sua vez, vai além e assevera ser necessário para o real implemento da democraria que os membros da sociedade possam se organizar, para que assim sejam ouvidos, o que torna a greve um mecanismo legítimo para que a democracia atinja os locais de trabalho ${ }^{12}$. Após destacar que o reconhecimento da greve como um direito é um meio fundamental para a defesa dos interesses dos trabalhadores por buscar igualdade substancial entre as partes do conflito coletivo, Luisa Galantino considera a greve um meio para a efetiva participação dos cidadãos-trabalhadores na vida econômica, social e política do país, sobretudo naqueles em que se reconhece a greve com motivação política $^{13}$.

Essas notas introdutórias evidenciam a importância e a relevância dos estudos acerca do direito de greve.

\subsection{ETIMOLOGIA DA GREVE}

Paulo Garcia destaca, em sua clássica obra sobre Direito de greve, que durante os períodos de desemprego ou mesmo durante as suspensões momentâneas do trabalho, os

\footnotetext{
${ }^{10}$ SILVA, Otavio Pinto e. A contratação coletiva como fonte do direito do trabalho. São Paulo: LTr, 1998, p. 95.

${ }^{11}$ Segundo o referido autor, na busca de peculiaridades próprias para se desgarrar do direito civil e exibir luz própria, o direito do trabalho apresentou um delicado equilíbrio em torno da subordinação como causa eficiente da relação de emprego, os infindáveis contornos sobre a negociação coletiva e seus impactos na vida de pessoas que dela não tomaram parte, mas que, nada obstante, vinculam-se aos resultados, e, enfim, ao reconhecimento do direito de greve. A greve, neste contexto, teria a enorme particularidade de ser uma manifestação sabidamente voltada para causar prejuízos econômicos ou jurídicos ao empregador e que, nada obstante, é reconhecida como um direito. (SILVA, Homero Mateus Batista da. Op cit, p. 255/256).

${ }^{12}$ MAIOR, Jorge Luiz Souto. Fundamentos para a solução dos conflitos coletivos de greve. In: MAIOR, Jorge Luiz Souto e CORREIA, Marcus Orione Gonçalves (orgs). Curso de Direito do Trabalho, vol. III, Direito coletivo do trabalho. São Paulo: LTr, 2008, p. 100.

${ }^{13}$ GALANTINO, Luisa. Diritto sindacale. Torino: Giappichelli Editori, 2009, p. 204.
} 
operários parisienses se reuniam na Praça do Hôtel de Ville para aguardar que lhes aparecesse um trabalho ou para discutir sobre os fatos relativos à suspensão de suas atividades laborais. Esta praça ficava próxima ao Rio Sena e era, durante as enchentes, constantemente invadida por suas águas, de modo que acabava acumulando seixos, pedregulhos e cascalhos que permaneciam em seu solo após as águas baixarem. Como estes detritos eram, na lingua francesa não culta, chamados de gravé, o local em questão passou a ser conhecido como Place de La Gravé e mais tarde, por um vício de pronúncia, como Place de La Grève. Assim teria surgido a palavra que mais tarde veio a dar o nome aos movimentos de suspensão do trabalho, uma vez que os operários, sempre que suspendiam o trabalho, iam se reunir na Place de la Grève ${ }^{14}$.

Em italiano usa-se a expressão própria sciopero e em inglês, strike. Em espanhol a palavra greve (huelga) deriva do verbo holgar, folgar em uma tradução livre, que significa suspender o trabalho, estar ocioso, descansar, tomar alento. Pérez del Castilho destaca a pertinência da expressão espanhola ao evidenciar que primitivamente ela era utilizada genericamente para denotar outras formas de estar sem desempenhar tarefas, não obstante, na atualidade, se tenha desprezado toda referência ao não trabalhar com ânimo de recreação, para consolidar-se no sentido de vacância não prazerosa e, ainda mais, de vacância com finalidade de protesto ${ }^{15}$.

A palavra greve, apropriação do epiteto francês pela língua portuguesa, vem, contudo, adquirindo, na linguagem coloquial, conotação bem mais ampla do que a original. Hodiernamente ela é atribuída a qualquer forma de manifestação coletiva, havendo inclusive precedentes judiciais que se referem à existência de uma greve trabalhista, como se houvesse outras formas de greve não relacionadas com as relações de trabalho ${ }^{16}$. José Carlos Arouca registra, em sua interessante análise do movimento sindical brasileiro, o trâmite, pelo Congresso Nacional, de um Projeto de Lei que reputava ilegal "a greve" deflagrada por motivos alheios às relações de trabalho ${ }^{17}$.

\footnotetext{
${ }^{14}$ GARCIA, Paulo. Direito de greve. Rio de Janeiro: Edições trabalhistas s.a, 1961, p. 7

${ }_{15}$ PÉREZ DEL CASTILLO, Santiago. O direito de greve. São Paulo: LTr, 1994, p. 19.

${ }^{16}$ A greve política não é um meio de ação direta da classe trabalhadora em benefício de seus interesses profissionais, e, portanto, não está compreendida dentro do conceito de greve trabalhista. Entende-se por greve política, em sentido amplo, a dirigida contra os poderes públicos para conseguir determinadas reivindicações não suscetíveis de negociação coletiva (TST-RODC 454136/98.7-(Ac.SDC)-Rel. Min. Valdir Rigueto).

${ }^{17}$ Em suas palavras: "O Projeto do DIAP, IV, pertinente à greve, estendia seu exercício para trabalhadores autônomos e avulsos; vedava o ajuizamento do dissídio coletivo desde a decretação até a cessação da parede e também dispensas dos trabalhadores envolvidos. Atribuía-lhes a definição dos serviços mínimos que seriam
} 
Tornou-se comum se falar em greve de estudantes. Em 2011 pelo menos dois movimentos estudantis alcunhados de greve ocuparam as manchetes de jornais. No Chile, estudantes se insurgiram contra o governo de Sebastian Piñera naquele que foi considerado pela imprensa local "el mayor movimiento estudantil de la época posterrorismo de Estado de Latinoamérica" ${ }^{\prime 18}$. No Brasil, grande destaque foi dado à greve dos estudantes da Universidade de São Paulo que ocuparam o prédio da reitoria em protesto contra a instalação da base móvel da Polícia Militar dentro das dependências do campus universitário e outras medidas adotadas pela cúpula da instituição. Durante o movimento foram realizadas assembleias para deliberar, entre outras coisas, sobre o adiamento da eleição para o diretório estudantil ${ }^{19}$.

Sem adentrar na discussão acerca da apropriação indevida ou não do vocábulo greve, é preciso registrar que o presente trabalho não cuidará da análise de manifestações não relacionadas com o trabalho, ainda que se considere oportuno chamá-las de greve.

Outra consideração terminológica imprescindível neste início de estudo diz respeito à distinção entre as palavras greve e coalisão, figuras que não se confundem. Coalisão é a forma de conseguir modificações nas condições de execução do contrato de trabalho, é o acordo de um grupo de trabalhadores ou de patrões para a defesa de seus interesses comuns. Como bem observa Paulo Garcia, pode haver coalisões que não conduzam necessariamente à greve, muito embora não possa existir greve sem coalisão. Isto porque é através da coalisão que os operários acertam seu ponto de vista, discutem seus problemas, formulam suas reivindicações, estudam, enfim, todos os meios e fórmulas necessárias à obtenção do que almejam ${ }^{20}$.

mantidos nas atividades que considerassem essenciais. Previa que a responsabilidade por qualquer ato de violência contra bens ou pessoas seria individual. Repercutiu o projeto elaborado pelo Ministro Almir Pazzianotto. A Confederação Nacional da Instústria - CNI apressou-se a preparar um projeto paralelo à guisa de sugestão; novidade, apenas a previsão expressa de cessada a vigência do acordo ou convenção, perderem a eficácia suas disposições, aviso prévio de oito dias e muita repressão, até dispensar por justa causa. Em debate promovido pelo jornal A Folha de São Paulo, com participação do Ministro, Octavio Bueno Magano, Jair Meneghelli, Joaquinzão dos Santos Andrade e dos dirigentes patronais, Flávio Telles de Menezes, da Socidade Rural Brasileira e Paulo Francini da FIESP, destaquei que só o propósito de definir o direito de greve já importava em sua limitação (Folha de São Paulo 4.6.85). Pelo projeto a greve seria ilegal se deflagrada por motivos alheios às relações de trabalho". (AROUCA, José Carlos. O sindicato em um mundo globalizado. São Paulo: LTr, 2003, p. 858)

18 Disponível em <http://www.lr21.com.uy/editorial/468700-chile-va-a-la-huelga-con-los-estudiantes>. Acesso em 22/12/2011.

${ }^{19}$ Disponível em < http://www.jornaldocampus.usp.br/index.php/2011/11/assembleia-geral-mantem-grevegeral-e-planeja-ato-na-avenida-paulista-para-2411>. Acesso em 22/12/2011.

${ }^{20}$ GARCIA, Paulo. Direito de greve. Rio de Janeiro: Edições trabalhistas s.a, 1961, p. 18. 
O mesmo autor distingue coalisão de associação. Esclarece que enquanto esta é um organismo permanente, estável, com finalidades várias, tendo personalidade jurídica, estando, enfim, circunscrito a determinadas normas previamente estipuladas e fixadas em lei, a coalisão é um agrupamento esporádico objetivando determinado fim. Atingido ele, dissolver-se-á e nada mais restará ${ }^{21}$.

Outro conceito fundamental ao presente estudo é o de autotutela. Ari Possidônio Beltran destaca que a autotutela implica no ato pelo qual alguém procura impor a outrem, em geral, pelo uso da força física, mas não raro por meio de coação psicológica ou moral, a solução de determinada pendência. Pressupõe, portanto, o exercício da própria defesa, constituindo-se na mais primitiva forma de solução de conflitos $^{22}$. Trata-se de mecanismo que nem sempre encontra sustentação no ordenamento jurídico. No Brasil, por exemplo, o exercício arbitrário das próprias razões constitui fato típico previsto no Código Penal. Tem-se entendido que dois são os motivos pelos quais, em determinadas circunstâncias, a autodefesa é admitida pelos ordenamentos. O primeiro consistiria no fato de ser impossível ao estado estar presente em todos os lugares e em todos os momentos em que um direito esteja sendo violado. O segundo seria a ausência de confiança que se possa ter no altruísmo alheio, inspirador de uma provável composição ${ }^{23}$.

Destacando a importância da autotutela para o direito do trabalho, Oscar Ermida Uriarte assevera que ela consiste na ação dos próprios trabalhadores tendente à proteção de seus direitos e interesses, seja para garantir o cumprimento das normas vigentes, seja para obter um progresso no nível de proteção atual. Seria, portanto, um conceito vinculado à noção de autonomia coletiva, segundo a qual, nas sociedades pluralistas, determinados grupos sociais possuem o poder de criar, dentro de certos limites, suas próprias normas. Constituiria, finalmente, uma consequência necessária e inseparável da liberdade sindical enquanto atividade sindical indispensável para sua existência ${ }^{24}$.

A relação entre greve e autotutela é de gênero e espécie. Entrelaçando conceitos aqui estudados, Gino Giugni considera a autotutela dos interesses coletivos uma das manifestações essenciais da coalisão sindical. Não obstante ela possa se exprimir de várias

\footnotetext{
${ }^{21}$ Ibidem, p. 18.

${ }_{22}^{22}$ BELTRAN, Ari Possidônio. A autotutela nas relações do trabalho. São Paulo: LTr, 1996, p.20.

${ }^{23}$ Ibidem, p. 25.

24 ERMIDA URIARTE, Oscar. Apuntes sobre la huelga. $2^{\mathrm{a}}$ ed. Fundación de cultura universitária. Montevideo: 1996, p. 9.
} 
outras maneiras, a mais típica e, por que não dizer, a mais importante, é o direito de greve. Em comum com as demais, a greve apresenta-se como forma de pressão em defesa de interesses coletivos, endereçada, em geral, à parte contrária no conflito sindical ${ }^{25}$. Ari Possidônio Beltran estuda como meios de autotutela nas relações de emprego outras formas de pressão utilizados pelos empregados como rattening, ocupação de estabelecimento, bloqueio de mercadorias, não-colaboração, boicote, sabotagem, label, listas negras, ca'canny, extorsão sindical; e diversos meios de pressão utilizados pelos empregadores como a ação administrativa empresarial, o poder disciplinar, prêmios antigreve ou de assiduidade, listas negras, listas brancas e o lockout ${ }^{26}$.

Esclarecido, portanto, o que não deve ser considerado greve, pelo menos na acepção que será adotada ao longo deste estudo, cumpre conceituar o que se deve entender por greve.

\subsection{CONCEITO DE GREVE}

Segundo Luisa Galantino a greve, na Itália denominada sciopero, consiste em “l'astensione colletiva dal lavoro disposta da una pluralità di lavoratori per la tutela dei propri interessi professionali, cioè degli interessi attinenti alla propria condizione sociale ed economica" 27 .

Héctor Humeres Noguer, por sua vez, conceitua greve, como “ la suspensión temporal, concertada y colectiva del trabajo, sea por causa económica, de derecho, o simple solidariedad con otros grupos y que persigue obtener logros que satisfagan dichas aspiraciones" 28 .

Segundo Fulvio Corso, a greve (sciopero) consistiria em "una sospensione concertata della loro attività lavorativa che priva le aziende del necessário contributo di energie umane, incidendo negativamente sulla produzione (bloccata o ridotta in misura più o meno consistente) e, quindi, sul profito del datore di lavoro" 29 .

${ }^{25}$ GIUGNI, Gino. Diritto sindacale. Aggiornato da Lauralba Bellardi, Pietro Cursio e Mario Giovanni Garofalo. Bari: Cacucci Editore, 2010, p. 231.

${ }^{26}$ BELTRAN, Ari Possidônio. A autotutela nas relações do trabalho. São Paulo: LTr, 1996.

${ }^{27}$ GALANTINO, Luisa. Diritto sindacale. Torino: Giappichelli Editori, 2009, p. 206.

${ }^{28}$ NOGUER, Héctor Humenes. Derecho del trabajo y de la seguridad social, tomo II: derecho colectivo del trabajo. $17^{\mathrm{a}}$ ed. Santiago: 2005, p. 265.

${ }^{29}$ CORSO, Fulvio. Il diritto sindacale. Torino: Giappichelli Editore, 2008, p. 97. 
Já para William Thayer Arteaga e Patricio Novoa Fuenzalida, a greve consistiria em "un acto jurídico colectivo, en virtud del cual una agrupación de trabajadores se concierta para suspender sus labores mientras no sean satisfechas sus aspiraciones de mejoramiento económico o social" ${ }^{30}$.

Raimundo Simão de Melo, por sua vez, assevera que "independentemente de ser um direito, é a greve um fato social, uma liberdade pública consistente na suspensão do trabalho, quer subordinado ou não, com o fim de se obter algum benefício de ordem econômica, social ou humana" ${ }^{\text {31 }}$. E conclui afirmando ser ela o direito de não trabalhar.

Analisando as definições antes transcritas e arvorando-nos dos ensinamentos de Bernard Teyssié, é possível destacar que a greve teria um elemento objetivo, a suspensão coletiva do contrato de trabalho, e diversos elementos subjetivos, a vontade de fazer greve, a concertação de vontades, a motivação da greve, a existência de reivindicações profissionais $^{32}$.

O elemento objetivo indica que a greve constitui uma abstenção coletiva da prestação de serviços por parte dos trabalhadores, em outras palavras, da suspensão proposital da principal obrigação de um dos sujeitos do contrato de trabalho, o empregado.

Muito se tem discutido acerca da caracterização da simples diminuição voluntária do ritmo de trabalho como greve. Na França, Bernard Teyssié faz remissão a decisões judiciais que não a reconhecem porque a greve pressuporia uma cessação do trabalho e não a sua execução de modo irregular ${ }^{33}$. Menciona, contudo, decisão com orientação mais flexível, segundo a qual uma greve pode ser reconhecida mesmo que os trabalhadores forneçam, em definitivo, um número normal de horas de atividade. Assim, enquanto a pessoa que atua durante o tempo de pausa de uma meia hora por revezamento para manter as máquinas de produção funcionando decide paralisar juntamente com os demais, no horário em comum, provocando assim a paralisação das máquinas do atelier, o movimento

\footnotetext{
${ }^{30}$ ARTEAGA, William Thayer e FUENZALIDA, Patricio Novoa. Manual de derecho del trabalho, tomo I, Generalidades, Derecho Colectivo del trabajo. $5^{\text {a }}$ edición. Santiago: 2007, p. 176.

${ }^{31}$ MELO, Raimundo Simão de. A greve no direito brasileiro. São Paulo: LTr, 2006, p. 44.

32 TEYSSIÉ, Bernard. Grève dans le secteur privé. Jurisclasseur Travail Traité, fasc. 70-10, 15 avril 2010.

33 "une simple diminution volontaire du rythme de travail, se traduisant par une baisse de cadence et, plus géréralement, de production, ne saurait être analyséee en une greve. Celle-ci comporte "une cessation du travail et non une exécution fautive" (Cass. soc., 22 févr. 1978: Bull. Civ. 1978, V, n. 135 apud TEYSSIÉ, Bernard. Grève dans le secteur privé. Jurisclasseur Travail Traité, fasc. 70-10, 15 avril 2010.).
} 
seguinte, concertado e visando uma modificação na organização do trabalho do atelier, constitui uma greve, mesmo se, em razão das modalidades paralisadas pelos assalariados, a duração do trabalho continue, por cada um deles, a mesma ${ }^{34}$.

O mesmo Bernard Teyssié destaca que essa exigência de cessação do trabalho conduz a jurisprudência de seu país a excluir do campo da greve não apenas os comportamentos adotados fora do período de trabalho efetivo, nele compreendendo os intervalos cumpridos dentro da empresa, os períodos de atraso obrigatoriamente pagos e as greves perlée e a greve de zelo ${ }^{35}$.

Após esclarecer que a greve perlée se caracteriza pela redução do ritmo de trabalho, sem, contudo, que toda a atividade seja paralisada, visando com isso pressionar o empregador a ceder às suas reivindicações, o mesmo Teyssié destaca, fazendo referência a diversos precedentes, que a Corte de Cassação Francesa se recusa a analisar este tipo de movimento como greve ${ }^{36}$.

A greve de zelo, por sua vez, não é, segundo o mesmo autor, considerada uma greve "autêntica" porque os empregados decidem não cessar totalmente o trabalho, mas aplicar escrupulosamente as regras, por exemplo, de segurança. Na França este tipo de

\footnotetext{
${ }^{34}$ Mais dès lors qu'une cessation de travail est observée, une grève peut être relevée meme si les salaries fournissent, en definitive, un nombre "normal" d'heures d'activité. Ainsi, lorsque le personnel posté qui, selon un usage ancient, prennait le temps de pause d'une demi-heure par roulement afin de mantenir les machines de production en marche, decide de prendre la pause en commun, ce qui provoque l'arrêt des machines de l'atelier, le mouvement suivi, concerté et tendant à une modification de l'organisation du travail de l'atelier, constitue une grève, même si, en raison des modalities arrêtées par les salariés, la durrée du travail reste, pour chacun d'eux, la meme (Cass. soc., 21juill. 1986: D. 1987, somm. P. 204, 1re esp., obs. M. - A. Roschild-Souriac). (TEYSSIÉ, Bernard. Grève dans le secteur privé. Jurisclasseur Travail Traité, fasc. 70-10, 15 avril 2010).

${ }^{35}$ Le critère emprunté à la cessation du travail conduit la jurisprudence à exclure du champ de la greve non seulement les comportements adoptés hors des périodes de travail effectif, y compris pendant les périodes de pause accomplies dans l'entreprise (Cass.soc., 18 déc. 2001: RJS 2002, n. 321) ou des périodes d'astreinte (Cass. Soc., 2 févr. 2006: RJS 2006, n. 487; JCP S2006, 1182, note R. Vatinet), mais aussi la grève perlèe et la grève du zèle. (Ibidem)

${ }^{36}$ La grève perlée est caractérisée par un ralentissement des cadences sans que tout activité soi arrêté. L'objectif visé par les salariés est bien d'exercer une pression sur l'employer en vue d'obtenir satisfaction de certaines revendications, mais ils se bornent, en la circonstance, à réduire leur rythme de travail. L'idée selon laquelle un mouvement, dès lors que répondant à des mots d'ordre collectifs, constituerait une véritable grève et n'autoriserait l'employer à prononcer des licenciements que si une faute lourde était relevée (le travail n'ayant pas été seulement effectué au ralenti mais de manière très defectueuse) n'a pas été acueillie par la jurisprudence. Après avoir souligné qu'il "n'y a pas arrêt du travail lorsque celui-ci est execute au ralenti ou dans des conditions volontairement défectueuses", la Cour de Cassation a refuse d'analyser ce type de mouvement en une grève (Cass. Soc., 5 mars 1953: D. 1954, jurispr.. p. 109; JCP G 1953, II, 7553, note H. Delpech - Cass. Soc., 18 déc. 1959: JCP G 1960, II, 11704, note F.D.; Dr. soc. 1960, p. 490, obs. H.F.-Cass. soc., 3 oct. 1963: D. 1964, jurisp. P. 19, note A. Rouast. - Cass. Soc., 6 jan 1972: JCP G 1972, II, 17148, note J. Savatier. - Adde, Nancy, 21 Nov. 2001: RJS 2002, n. 933). (TEYSSIÉ, Bernard. Grève dans le secteur privé. Jurisclasseur Travail Traité, fasc. 70-10, 15 avril 2010).
} 
greve tem sido comum na administração aduaneira, no serviço postal e no serviço de controle aéreo. Em todos esses casos o zelo tem por resultado a rápida paralisação do setor de atividade ou da empresa que, de maneira um pouco paradoxal, sofre exacerbadamente os efeitos deste retardamento. $\mathrm{O}$ fato de os manifestantes não invocarem o direito de greve para sua proteção restaria sem maior importância na medida em que o zelo não poderia ser comparado a uma falta. Não poderá ser considerada má-execução do contrato na medida em que eles assegurem o mínimo de produtividade que o empregador lhes houver imposto $^{37}$.

Não basta a paralisação coletiva do trabalho para que se conclua pela existência de uma greve $\mathrm{e}^{38}$. O elemento volitivo é fundamental para caracterizar o movimento, na medida em que, como bem evidencia Uriarte, a greve não consiste em um não trabalhar por preguiça, por ociosidade, ela "es un no trabajar como forma de protesta, como forma de reclamo, en el que está presente el carácter reivindicativo de la huelga, el carácter conflictivo de la huelga, su carácter de instituto de autotutela",39. Por meio dela os trabalhadores utilizam sua arma mais poderosa - sua negativa temporal em trabalhar e produzir - para pressionar e de alguma maneira forçar o seu empregador, objetivando com isso obter algo ou defender algo que conquistaram anteriormente ${ }^{40}$.

É preciso ainda que o elemento volitivo seja compartilhado por um grupo expressivo de trabalhadores. Não sendo assim, "La concertation se réduit alors à la simple reencontre d'intentions individuelles. C'est dire qu'elle n'ajoute guère au caractere collectif de la greve" ${ }^{\prime 1}$.

\footnotetext{
37 "La grève du zèle ne saurait être considérée comme une grève authentique puisque les salariés décident non pas de cesser tout travail mais d'appliquer scrupuleusement les consignes, par exemple de sécutiré. De tels mouvements ont, notamment, pu être relevés dans les administrations de la douane et de la poste ainsi que de la parte des contrôleurs de la navigation aérienne. Dans tous les cas, le "zéle" a pour résultat la rapide paralysie du secteur d'activité ou de l'entreprise qui, de manière quelque peu paradoxale, en souffre. Que les salariés ne puissent invoquer, pour leur protection, le droit de grève reste, d'ailleurs, sans grande conséquence. Le zéle ne saurait, en effet, être assimile à une faute. Une mauvaise execution du contrat de travail ne saurait leur être reprochée dès lors, toutefois, qu'ils assurent le minimum de production qui leur est impose". (TEYSSIÉ, Bernard. Ibidem).

${ }^{38}$ Como enfatiza Bernard Teyssié, "Il ne suffit pas d'observer une cessation collective du travail pour conclure á l'existence d'une grève. Encore faut-il que les intéressés aient la volonté de participer à un tel mouvement et l'accompagnent de revendications". (Ibidem).

39 ERMIDA URIARTE, Oscar. Apuntes sobre la huelga. $2^{\mathrm{a}}$ ed. Fundación de cultura universitária. Montevideo: 1996, p.38.

${ }^{40}$ Cf. GARCIA NINET, José Ignacio e SALIDO BANÚS, José Luis. La huelga.In: GARCIA NINET, J. Ignacio(dir) e VICENTE PALACIO, Arántzazu. Derecho del Trabajo. $5^{\text {a }}$ Edición.Pamplona: Thomson Reuters, 2009, p.789.

${ }^{41}$ TEYSSIÉ, Bernard. Grève dans le secteur privé. Jurisclasseur Travail Traité, fasc. 70-10, 15 avril 2010.
} 
O fim buscado precisa ser profissional. Após ressaltar não ser, em sua visão, necessário que as reivindicações dos grevistas sejam previamente apresentadas ao empregador, Bernard Teyssié destaca ser imprescindível que elas existam e estejam inseridas dentro de uma finalidade profissional ${ }^{42}$. Citando precedentes da jurisprudência de seu país, o autor francês destaca que o movimento que não corresponde a alguma reinvindicação profissional não pode ser qualificado como greve $\mathrm{e}^{43}$ e que tampouco merece esse qualificativo a paralisação do trabalho provocada por um evento de força maior ou por circunstâncias outras que tornam muito difícil o cumprimento das prestações normalmente devidas ${ }^{44}$.

Vale mencionar ainda uma expressiva decisão da Seção de Dissídios Coletivos do Tribunal Superior do Trabalho na qual se consignou que a greve foi elevada à estatura de direito social, cuja oportunidade de exercício e os interesses a serem defendidos compete aos trabalhadores decidir. E que, por conseguinte, ela não se afigura abusiva, no tocante à motivação, sempre que cuidar de pretensão de natureza trabalhista, contrastável ante o empregador ${ }^{45}$.

Os motivos a ensejar uma greve legítima são os mais variados possíveis. Após minuciosa análise no repertório jurisprudencial de seu país, Bernard Teyssié, observa que a qualificação de greve deve ser reservada às paralisações de trabalho destinadas a apoiar reivindicações profissionais que interessem aos trabalhadores que participem do movimento, como aumento de salário, melhoria das condições de segurança e saúde no trabalho, adoção de um plano de cargos e salários ${ }^{46}$; estabelecimento da data das eleições

\footnotetext{
42 S'il n'est point nécessaire que les revendications des grévistes aient fait l'objet d'une présentation préalable, encore faut-il qu'elles existente et s'inscrivent dans une finalité professionnelle. (Ibidem).

${ }^{43}$ Cass. Soc., 17 déc. 1996: TPS 1997, comm. 85 apud TEYSSIÉ, Bernard. Ibidem.

${ }^{44}$ Il n'y a point grève lorsque l'arrêt de travail est commandé par un événement de force majeure ou par des circonstances qui, sans mériter la qualification précédent, rendent três difficile l'accomplissement des prestations normalement dues. Tel est le cas lorsque l'interruption d'activité est liée aux défaillances du système de chauffage d'un atelier (Cass. soc., 10 juin 1971: Bull. Civ. 1971, V, n. 439 apud TEYSSIÉ, Bernard. Ibidem).

${ }^{45}$ Dissídio coletivo - Greve - abusividade - motivação - Pretensões de caráter trabalhista - 1. A Constituição da República de 1988 (art. 9º caput) elevou a greve à estatura de direito social, cabendo aos trabalhadores decidir sobre a oportunidade de exercê-la e sobre os interesses que devam por meio dela defender. 2. Se se cuida de pretensão de natureza trabalhista, contrastável ante o empregador, a greve não se afigura abusiva, no tocante à motivação. 3. Recurso ordinário interposto pela Empresa Suscitante a que se nega provimento, no particular. (TST-RODC 853/2005-000-15-00.2-(Ac. SDC) -Rel. Min. João Oreste Dalazen - DJ $\left.1^{\circ} .6 .2007\right)$.

${ }^{46}$ Cass. Soc., 25 févr. 1985: JCP G 1985, IV, 169 apud TEYSSIÉ, Bernard. Grève dans le secteur privé. Jurisclasseur Travail Traité, fasc. 70-10, 15 avril 2010.
} 
profissionais ${ }^{47}$, defesa de direitos sindicais ${ }^{48}$; aumento da delegação sindical encarregada de negociar uma convenção coletiva ou um acordo coletivo de empresa ${ }^{49}$; obtenção de um estatuto particular ${ }^{50}$; defesa de um sistema de aposentadoria ${ }^{51}$.

Teyssié destaca ainda, novamente referindo-se à precedentes de tribunais franceses, que a greve política não consiste em uma greve autêntica ${ }^{52}$. Esta última observação merece uma consideração especial. A natureza política do movimento não deve, por si só, descaracterizá-lo enquanto greve. Pelo menos, não em uma análise apriorística. É possível que a reivindicação política buscada por meio dele tenha cunho profissional, como por exemplo, mudanças na legislação trabalhista própria de uma determinada profissão especial regulamentada ou no critério geral de aposentadoria da nação ${ }^{53}$, o que preencheria o requisito antes mencionado ${ }^{54}$. Pode haver, contudo, alguma implicação relacionada com os efeitos da greve, em especial no tocante às suas implicações para o empregador. Isto, no entanto, será objeto de análise em um dos tópicos seguintes.

A abstenção precisa também ser motivada e destinar-se a um fim específico de melhoria de condição social. Esta é uma das características que a faz ser forma de suspensão da relação laboral, não de sua extinção. Os trabalhadores em greve seguem sendo trabalhadores regidos pela mesma relação laboral que os ligava antes da deflagração

${ }^{47}$ CA Toulouse, 8 nov. 1962: D. 1963, jurispr. P. 29. Ibidem.

${ }^{48}$ Cass. Soc., 30 mars 1999: RJS 1999, n. 725. Ibidem.

${ }^{49}$ Cass. Soc., 19 oct. 1994: Dr. Soc. 1994, p. 958, rapp. Ph. Waquet. Ibidem.

${ }^{50}$ Cass. Soc., 26 sept. 1990: Cah. Soc. 1990, A52, à propos de l'obtention de la position chômageintempéries. Ibidem.

${ }^{51}$ Cass. Soc. 30 janv. 2008: RJS 2008, n. 470. Ibidem.

${ }^{52}$ V. Cass. Soc., 23 mars 1953: JCP G 1953, II, 7709, note H. Delpech; D. 1954, jurispr.. p. 89, note G. Levasseur, qui prefere néanmoins se placer sur le terrain de la licéité du mouvement. - Adde, Cass. Soc., 14 oct. 1954: Dr. Soc. 1955, p. 102. - Cass. Soc., 4 mai 1956: JCP G 1956, II, 9422. - Cass. Soc., 5 oct. 1960: D. 1960, jurispr.. p. 710. - Cass. Soc., 10 mars 1961: Dr. Soc. 1961, p. 363. - Rappr. CE, 8 févr. 1961: Rec. CE 1961, p. 85, concl. Braibant . Ibidem.

${ }^{53} \mathrm{Na}$ França, no dia 7 de setembro de 2010, 220 manifestações foram feitas contra a reforma do sistema de aposentadoria proposta pelo Presidente Nicolas Sarkozy, contando, segundo estimativas do ministério do interior, com 1.120.000 pessoas. Informação obtida no sitío do jornal Le Monde na rede mundial de computadores. Disponível em <http://www.lemonde.fr/politique/article/2010/09/07/la-contestationsyndicale-sur-les-retraites-gagne-du-terrain_1408099_823448.html>. Acesso em 22/12/2011.

${ }^{54}$ Esta conclusão parece ser compartilhada, em certa medida por Bernard Teyssié, segundo quem para que a paralisação do trabalho seja considerada uma greve ela deve apresentar reivindicações profissionais, sejam elas próprias da empresa ou tenha ela por objetivo apoiar reivindicações profissionais formuladas no plano nacional. Em suas palavras, com as referências feitas por ele à precedentes da jurisprudência francesa: "Pour qu'un arrêt de travail soi considere comme une greve, il faut qu'il se rattache à des revendications professionnelles (Cass. Soc., 18 janv. 1995: Dr. Soc.1995, p. 183, rapp. Ph. Waquet. - Cass. Soc., 19 déc. 1996: RJS 1997, n. 85, 1re esp.), qu'elles soient propres à l'entreprise, avait pour but d'appuyer des revendications professionnelles formulées sur le plan national. - Cass. soc., 15 févr. 2006: RJS 2006, n. 622; JCP S2006, 1364, note R. Vatinet, où la grève était intervenue au soutien d'un mot d'ordre national pour la defense des retraites)". Apud TEYSSIÉ, Bernard. Grève dans le secteur privé. Jurisclasseur Travail Traité, fasc. 70-10, 15 avril 2010. 
do movimento, mas as partes deste liame quedam, momentaneamente, dispensadas de executar suas principais obrigações contratuais.

A suspensão do trabalho corresponde inevitavelmente à suspensão do pagamento correspondente e, como salientam Pélissier, Supiot e Jeammaud, “Cette conséquence n'est pas une sanction qui serait irrégulière mais un effet de la suspension" ${ }^{55}$.

O empregador não pode, por conseguinte, extinguir unilateralmente a relação e as partes devem, durante a paralisação, observar suas demais obrigações contratuais. Se é certo que a greve não constitui, por si só, motivo para a rescisão motivada ou imotivada do contrato de trabalho, não podendo ser considerada desídia, nem tampouco o descumprimento de determinadas orientações ser reputada insubordinção ou indisciplina, igualmente correto é que atos praticados durante a greve, como, por exemplo, agressão física ou ofensa moral ao empregador ou superior hierárquico, poderão caracterizar justa causa.

No tocante ao direito brasileiro é importante destacar que a Constituição consagra uma definição bastante ampla, na medida em que enfatiza o direito de greve, assegurando competir aos trabalhadores decidir sobre as oportunidades de exercê-lo e sobre os interesses que devam por meio dele defender. A norma, como se pode facilmente concluir, destina-se aos trabalhadores, gênero do qual os empregados são espécie. Ela também é taxativa ao asseverar serem eles os únicos competentes para decidir sobre a oportunidade de exercer o direito em questão e definir quais interesses deverão por meio deles defender. O Texto Maior delegou à lei, apenas e tão somente, a definição dos serviços ou atividades essenciais e a disciplina do atendimento das necessidades inadiáveis da comunidade ${ }^{56}$. Deixou claro, contudo, que a greve não consiste em direito absoluto e sujeitou os atos abusivos às penas da lei.

Analisando o aludido dispositivo constitucional, Octávio Bueno Magano e Estêvão Mallet ressaltam que ele evidencia que o constituinte não quis tratar a greve como concessão feita pelo Estado aos trabalhadores, preferindo antes caracterizá-la como

\footnotetext{
${ }^{55}$ PÉLISSIER, Jean; SUPIOT, Alain; JEAMMAUD, Antoine. Droit du travail. 21 ed. Paris: Dalloz, 2002, p. 1245.

${ }^{56}$ Compartilhando desta opinião, Antonio Escosteguy Castro, afirma que "O artigo $9^{\circ}$ assegura o direito de greve, atribuindo aos trabalhadores o poder de administrá-lo. Somente a greve nas atividades essenciais e os abusos em seu exercício é que seriam regrados" (CASTRO, Antonio Escosteguy. Trabalho, tecnologia e globalização: a necessidade de uma reforma sindical no Brasil. São Paulo: LTr, 2006, p. 180).
} 
prerrogativa inscrita no poder autônomo que lhes é peculiar, quando organizados. Destacam, ainda, que ele achou por bem explicitar duas faculdades contidas no âmbito da referida prerrogativa, quais sejam, a de escolha da oportunidade de deflagração da greve e a da determinação de seu âmbito ${ }^{57}$.

Em termos de legislação infraconstitucional, cabe aqui pontuar que o art. $2^{\circ}$ da Lei n. 4.330, de 1964 considerava "exercício legítimo da greve a suspensão coletiva e temporária da prestação de serviços a empregador, por deliberação da Assembléia Geral de entidade sindical representativa da categoria profissional interessada na melhoria ou manutenção das condições de trabalho vigentes na empresa ou empresas correspondentes à categoria, total ou parcialmente, com a indicação prévia e por escrito das reivindicações formuladas pelos empregados, na forma e de acordo com as disposições previstas na lei”.

Em obra publicada no início dos anos 1990, Amauri Mascaro Nascimento destacava que a greve constituía, sob a égide da aludida lei, um procedimento sujeito a forma expressa em lei, razão pela qual não recebiam esse adjetivo os movimentos paredistas realizados em desacordo com o modelo jurídico como, por exemplo, a greve selvagem, assim entendida aquela que eclode na empresa à margem da organização sindical $^{58}$. Outra formalidade excessiva da aludida lei era a exigência de que os trabalhadores indicassem, expressamente e por escrito, quais eram suas reinvindicações, as quais tinham, ainda, que ser trabalhistas, haja vista precisarem ser pertinentes às condições de trabalho cuja melhoria ou manutenção fosse desejada.

A definição em questão não foi recepcionada em sua literalidade pelo texto constitucional. Ao declarar que compete aos trabalhadores definir a greve, o artigo $9^{\circ}$ da Constituição permitiu que se atribuisse a titularidade do direito de greve não mais ao sindicato, como vinha sendo, mas aos trabalhadores. Segundo Amauri Mascaro Nascimento, o novo texto constitucional teria dispensado a exigência de deliberação pela assembleia sindical para declaração de greve, bastando o pronunciamento dos trabalhadores, ainda que sem aprovação do sindicato. Em sua opinião a constituição teria adotado uma mais ampla admissibilidade das greves, afirmando que o seu objetivo "não é

\footnotetext{
${ }^{57}$ MAGANO, Octávio Bueno; MALLET, Estêvão. O direito do trabalho na constituição. Rio de Janeiro: Forense, 1993, p. 308.

58 NASCIMENTO, Amauri Mascaro. Direito do trabalho na Constituição de 1988. $2^{\mathrm{a}}$ edição. São Paulo: Saraiva, 1991, pp.287/288.
} 
mais aquele indicado pela lei, mas o resultante da própria opção dos trabalhadores, dentre os fins cuja defesa através da greve forem julgados oportunos" ${ }^{\text {} 59}$.

Diante de tantas incompatibilidades entre a Lei n. 4.330, de 1964 e a nova ordem constitucional, nova lei de greve foi editada antes mesmo do primeiro aniversário da Carta Magna. Embora tenha apresentado alguns avanços em relação a norma por ela substituída, a Lei 7.783/89 repetiu alguns erros da anterior. O principal deles foi insistir em apresentar no seu artigo a seguinte definição de greve: "legítimo exercício do direito de greve a suspensão coletiva, temporária e pacífica, total ou parcial, de prestação pessoal de serviços a empregador".

A opção por uma definição legal de greve é sempre arriscada, pois, como salienta Oscar Ermida Uriarte, ela pode encerrar uma sutil e sofistada, porém nem por isso menos grave, restrição ao seu exercício. O autor uruguaio refere-se inclusive a uma estratégia político legislativa, chamada pelos italianos de "técnica definitória", mediante a qual se estabelece uma definição de greve tão estreita que deixa fora do conceito legal uma série de atividades que habitualmente os sindicatos e os trabalhadores coletivamente organizados adotam como greve ${ }^{60}$.

No caso brasileiro a definição legal deixou de fora situações como a greve de zelo e a greve perlê, sobre as quais já se discorreu anteriormente, e, aparentemente, os movimentos feitos por trabalhadores cuja relação não é regida por um contrato de trabalho.

Primeiramente há que se esclarecer que, nos termos da legislação brasileira, suspensão coletiva não é apenas a paralisação das atividades de todos os trabalhadores da empresa, de todos os seus estabelecimentos ou de todos os setores destes, vez que a lei também considera legítimo exercício do direito de greve a paralisação parcial da prestação pessoal de serviços. Suspensão coletiva seria, em verdade, aquela definida pela entidade sindical na forma de seu estatuto (art. $4^{\circ}$ da Lei 7.783/89), ou, na falta desta, pela assembleia geral dos trabalhadores interessados (art. $4^{\circ}, \S^{\circ}$ da Lei 7.783/89), independentemente do número de trabalhadores que efetivamente paralisarem suas atividades. Como salienta Homero Mateus Batista da Silva, ser coletiva não significa

\footnotetext{
${ }^{59}$ NASCIMENTO, Amauri Mascaro. Direito do trabalho na Constituição de 1988. $2^{\mathrm{a}}$ edição. São Paulo: Saraiva, 1991, p.287/288.

${ }^{60}$ ERMIDA URIARTE, Oscar. Apuntes sobre la huelga. $2^{\mathrm{a}}$ ed. Fundación de cultura universitária. Montevideo: 1996, p. 136.
} 
paralisar $100 \%$ dos serviços prestados a empregador, havendo diversos empregadores com matriz e filiais, com dezenas de departamentos e seções, com ânimos mais exaltados em alguns setores desguarnecidos do que em outros setores mais favorecidos e assim sucessivamente. Ademais, não se pode olvidar a existência de imposição legal de manutenção da realização de serviços essenciais ${ }^{61}$.

Esta situação assemelha-se à da França, onde, segundo Pélissier, Supiot e Jeammaud, “Il n'est pas nécessaire à sa régularité que la grève interesse tous les ateliers ou tous les services, toutes les catégories de persones d'une entreprise ou d'une profession" 62 .

Há que se registrar ainda que, embora precise ser temporária, a greve no Brasil não precisa ter a sua duração pré-estabelecida sendo perfeitamente válidas as paralisações por tempo indeterminado. Segundo Homero Mateus Batista da Silva "ela deve durar apenas o tempo essencial para o exercício da pressão em prol da negociação" ${ }^{63}$. Corroborando esta assetiva há o fato de a lei considerar exercício abusivo do direito de greve a manutenção da paralisação após a celebração de acordo, convenção ou decisão da justiça do trabalho (art. 14, caput, da Lei 7.783/89). Na vigência de uma destas fontes, só será admitida greve que tenha por objetivo exigir o cumprimento de cláusula ou condição, ou seja motivada pela superveniência de fato novo ou acontecimento imprevisto que modifique substancialmente a relação de trabalho (Art. 14, parágrafo único, I e II).

É preciso reconhecer também, e esta constatação tem especial importância para o fim a que se propõe o presente trabalho, que a manifestação precisar ser pacífica.

O conceito de greve expresso na legislação brasileira vem sendo alvo de diversas críticas. Segundo Homero Mateus Batista da Silva, ao afirmar que a greve deve ser "a suspensão coletiva, temporária e pacífica, total ou parcial, de prestação pessoal de serviços a empregador", o legislador olvidou-se de outras manifestações de pressão dos trabalhadores que não suspendem os trabalhos. Seriam exemplos destas manifestações os chamados de operação tartaruga, operação padrão etc. - além das manifestações contra

\footnotetext{
${ }^{61}$ SILVA, Homero Mateus Batista da. Curso de direito do trabalho aplicado, vol. 7: direito coletivo do trabalho. Rio de Janeiro: Elsevier, 2010, p. 257.

${ }^{62}$ PÉLISSIER, Jean; SUPIOT, Alain e JEAMMAUD, Antointe. Droti du travail. 21 ed. Paris: Dalloz, 2002, p. 1233 .

${ }^{63}$ SILVA, Homero Mateus Batista da. Op cit, p. 257.
} 
tomadores de serviço e contra o órgão gestor de mão-de-obra, pressão de trabalhadores autônomos etc ${ }^{64}$.

A definição legal, com efeito, apresenta-se muito adequada para o padrão fordistataylorista de produção. Não se mostra adequada, contudo, às novas situações criadas e desenvolvidas pela tecnologia. Atento a esta questão, Márcio Túlio Vianna adotava, já em meados dos anos 1990, um conceito amplo para a greve. Em sua opinião a greve seria não apenas a paralisação coletiva, mas qualquer ruptura do cotidiano da prestação de serviços, abrangendo, por conseguinte, greves como a de zelo. Não abrangeria, contudo, atos como o de sabotagem ${ }^{65}$. Essa definição se mostra mais adequada ao momento atual por abranger as novas formas de greve, sobre as quais se discorrerá no próximo item.

\subsection{ASPECTOS HISTÓRICOS DO DIREITO DE GREVE}

Alguns estudiosos do direito do trabalho identificam movimentos precursores da greve como a conhecemos nos tempos modernos, no abandono coletivo do trabalho feito pelos escravos que construíram as pirâmides do Egito, nas guerras servis inspiradas e dirigidas por Espártacus, assim como nas organizadas pelo grêmio de tocadores de flauta de Roma. Há até quem afirme que as retiradas da plebe romana até o Monte Sagrado (monte Aventino) para protestar contra a sua situação social ou contra o abuso do governo dos partidos seriam embriões dos movimentos paredistas verificados anos depois. É preciso, contudo, reconhecer que nenhum destes movimentos merece a qualificação de greve, já que nos primeiros casos mencionados se referiam a trabalho servil, escravo, no dos tocadores de flauta não ia dirigido a um empregador determinado, e no da retirada da plebe não passava de um protesto coletivo, não necessariamente de trabalhadores, nem dirigidos contra alguma pessoa ou ente determinado ${ }^{66}$. Como complementa Ari Possidônio Beltran, tais fatos têm significação somente como referências históricas, já que não passavam de revoltas ou movimentos coletivos de protestos contra a opressão e a violência,

\footnotetext{
${ }^{64}$ SILVA, Homero Mateus Batista da. Curso de direito do trabalho aplicado, vol. 7: direito coletivo do trabalho. Rio de Janeiro: Elsevier, 2010, p. 258.

${ }^{65}$ VIANA, Márcio Túlio. Direito de resistência: possibilidades de autodefesa do empregado em face do empregador. São Paulo: LTr, 1996, p. 285.

${ }^{66}$ NOGUER, Héctor Humenes. Derecho del trabajo y de la seguridad social, tomo II: derecho colectivo del trabajo. $17^{\mathrm{a}}$ ed. Santiago: 2005, p. 268.
} 
numa época em que não havia como se cogitar da liberdade de trabalho e assim, muito menos de uma greve ${ }^{67}$.

Embora adotasse interpretação restritiva, entendendo que só impropriamente se poderia dar o nome de "greve" a atitudes que, na verdade, eram sedições, rebeliões ou motins de escravos contra a opressão e a violência dos seus senhores porque, não tendo direitos pessoais, eles não passavam de instrumento, de ferramenta humana de trabalho, Délio Maranhão considerava provável que um verdadeiro movimento paredista tivesse ocorrido no tempo de Aurélio, entre os operários fabricantes de moedas que trabalhavam para o Estado. Aduz ainda que esta e outras manifestações teriam resultado na expedição de regulamentações especiais abrangendo várias classes ${ }^{68}$.

O mesmo autor destaca que a existência de uma sociedade rigorosamente organizada na Idade Média, com rígida hierarquia, seria incompatível com a greve. Justifica afirmando que a produção era feita em quantidades reduzidas e destinadas ao consumo da própria comunidade, dentro de uma organização patriarcal, havendo, no campo, domínio do regime da servidão em que o trabalhador e sua família acompanhavam a terra arrendada ou comprada. Nem mesmo as violentas rebeliões de trabalhadores rurais verificadas especialmente na Rússia, na Romênia e na Hungria poderiam ser entendidas como greves por lhes faltar o estatuto pessoal, a liberdade de ação e manifestação. Elas seriam na verdade conflitos entre "grandes" e "pequenos", por causa dos abusos da administração oligárquica ${ }^{69}$.

Essas lutas violentas contra privilégios e monopólios, que colocavam quase sempre do lado dos rebelados os trabalhadores, como classe sofredora e explorada, teriam desencadeado uma série de medidas visando evitar que eles continuassem a se unir em torno de interesses comuns ${ }^{70}$.

Em um primeiro momento essas coalizões teriam sido punidas como rebeliões contra o poder constituído. Paulatinamente foram surgindo leis proibindo coalizões de

\footnotetext{
${ }^{67}$ BELTRAN, Ari Possidônio. A autotutela nas relações de trabalho. São Paulo: LTr, 1996, p. 207.

${ }^{68}$ SÜSSEKIND, Arnaldo; MARANHÃO, Délio; VIANNA, Segadas e TEIXEIRA, Lima. Instituições de direito do trabalho, vol. 2. 20 edição atualizada por Arnaldo Süssekind e Lima Teixeira. São Paulo: LTr, 2002, p. 1212/1213.

${ }^{69}$ SÜSSEKIND, Arnaldo; MARANHÃO, Délio; VIANNA, Segadas e TEIXEIRA, Lima. Instituições de direito do trabalho, vol. 2. 20 edição atualizada por Arnaldo Süssekind e Lima Teixeira. São Paulo: LTr, 2002, p. 1213.

70 Ibidem.
} 
trabalhadores como as expedidas pelo Patriarca da Aquiléa, em 1236; as de Bolonha, em 1212; as de Pádua, em 1271; as do monarca inglês Eduardo I, em 1305; e as do monarca Francês Charles V, em $1243^{71}$.

Também da França são as ordenanças de 1355, 1382, 1401 e 1466 que dissolveram as confrarias de trabalhadores. Em 1500 o parlamento de Paris teria ainda ordenado que se investigasse com que pretendido direito eles se reuniam e conspiravam. O intuito era nitidamente repressor. Alguns anos depois, mais precisamente em 1508, Luís XII expediu nova Ordenança proibindo as coalizões e, no ano seguinte, a Ordenança de VillersCotterets estabelecendo que era terminantemente proibida qualquer congressão ou assembleia, de empregados camponeses ou empregados de qualquer espécie, independentemente do pretexto. Esta última ordenança proibiu, ainda qualquer tipo de entendimento mútuo sobre questões de trabalho, sob pena de prisão e confisco de bens ${ }^{72}$.

Na Alemanha houve em 1371 uma paralisação de trabalhadores, que teria sido reprimida com o enforcamento de 32 manifestantes. Também lá foram editadas as Ordenações Imperiais de 1577 e 1731 que puniam com graves penas as coalições ${ }^{73}$.

Segundo Héctor Humenes Noguer, dois teriam sido os fatores determinantes do surgimento do direito de greve. O primeiro seria o advento do maquinismo. O segundo a condição dos trabalhadores, reconhecida primeira como uma situação de fato e depois, como logo mais se verá, como um direito, que lhes permitiu exercer coação sobre os empregadores. No regime anterior à Revolução Industrial, em que as corporações de ofício tinham grande importância, o trabalhador se sentia duplamente protegido já que o grêmio a que pertencia controlava e monopolizava a produção, o que lhe assegurava trabalho permanente e a venda dos produtos que fabricava e ele podia contar com sua habilidade manual que lhe permitia escalar os distintos graus dentro da corporação e dar, ao mesmo tempo, expressão às suas aptidões artísticas. Não fosse isto o bastante, ele ainda obtinha o pleno desenvolvimento e aplicação de sua personalidade em um ambiente de harmonia e quase familiar. Não sem razão, durante o regime das corporações, as coalizões dos

\footnotetext{
${ }^{71}$ Ibidem, p. 1214.

${ }^{72}$ Ibidem.

${ }^{73}$ Ibidem.
} 
agremiados eram inaceitáveis e vistas como insurreições contra as organizações sociais do trabalho ${ }^{74}$.

Na mesma linha de raciocínio Wilson de Souza Campos Batalha destaca que "o problema das greves e dos agrupamentos para a defesa dos interesses dos trabalhadores, primeiro como coalizões transitórias, depois como sindicatos permanentes, começou a surgir com a abolição das instituições corporativas" ${ }^{75}$. Como as antigas corporações constiuíam organismos que englobavam todos os fatores da mesma atividade econômica, organizados hierarquicamente, não era possível distinguir as organizações representativas de categorias econômicas das organizações representativas das categorias profissionais. As corporações eram organismos fechados e monopolizadores de determinadas atividades ${ }^{76}$.

Diversos fatores levaram ao fim das corporações de ofício. Sob o aspecto tecnológico, a utilização primeiramente da máquina de tecer, e em momentos posteriores das fábricas e das grandes indústrias, terminou não só com a instituição denominada corporação de ofício, como também com as distinições baseadas na destreza pessoal do artífice, até então existentes. Não se necessitava mais de uma habilidade manual diferenciada para obter graus, honras ou melhor pagamento. A máquina nivelou os trabalhadores, eliminando as diferenças existentes segundo as aptidões pessoais ${ }^{77}$. Em outras palavras, tornou os trabalhadores fungíveis.

Outros fatores de ordem social, histórica e religiosa também contribuíram para o fim do esplendor das corporações de ofício e, em um segundo momento, para o seu desaparecimento. O descobrimento de novas e ricas terras, o comércio internacional, a reforma religiosa, a criação de bancos e bolsas de comércio, a aceitação das operações de crédito pela Igreja e a superabundância de moeda fundida com ouro e prata encontrados no "novo mundo" estariam entre estes fatores. Pouco a pouco, por todos estes setores, o mundo vai se tornando capitalista e substituindo o regime dos câmbios simples e diretos do pequeno atelier, que satisfaz as necessidades da cidade, por uma nova economia complexa e artificial baseada na especulação e nos signos representativos do valor. A partir do momento em que não se produz mais no mundo para atender necessidades humanas, mas

\footnotetext{
${ }^{74}$ NOGUER, Héctor Humenes. Derecho del trabajo y de la seguridad social, tomo II: derecho colectivo del trabajo. $17^{\mathrm{a}}$ ed. Santiago: 2005, pp. 268/269.

${ }^{75}$ BATALHA, Wilson de Souza Campos. Sindicatos, sindicalismo. São Paulo: LTr, 1992, p.206.

${ }^{76}$ Ibidem, p.207.

${ }^{77}$ NOGUER, Héctor Humenes. Op cit, p. 268/269.
} 
para apetecer o capital, para as exigências derivadas dos investimentos em dinheiro e do emprego lucrativo deste, começa-se a fase em que a economia torna-se dirigida e dominada exclusivamente pelo capital $^{78}$.

Como salienta Evaristo de Moraes Filho, com as descobertas mecânicas do século XVIII, com o aproveitamento em larga escala da força-vapor, era aberta uma nova estrada à indústria com a promessa de uma produção sem limites. $\mathrm{O}$ homem passava então a não precisar se fixar em certos locais da natureza, privilegiados, para aproveitar-se diretamente de seus elementos - rios, quedas d'agua, ventos, declíves, etc. na movimentação de seus primitivos engenhos mecânicos. Com o advento da máquina a vapor, ele passou a poder se deslocar para onde quiser, levando consigo o meio capaz de acionar todo o seu imenso e complicado instrumental de trabalho. O comércio passou a encontrar novos caminhos de expansão, levando os seus produtos a mercados afastados, do outro lado da terra, quebrando a rotina da feira e do mercado próximo, para as populações vizinhas. O consumidor passou a não mais precisar viajar até o produto, pois o produto passou a ir até o consumidor ${ }^{79}$.

Referido autor destaca ainda que numa sociedade tão embriagada pela produção em massa e pelos lucros ilimitados, tudo que representasse estorvo e manietação precisava ser destruído. Nada de monopólio, nada de empecilho à liberdade de indústria e de comércio. Todos e cada um deveriam poder fabricar aquilo que bem entendessem, desde que não ofendessem a ordem pública. O grupo não deveria mais impedir o indivíduo de usar e gozar da sua liberdade sem constrangimento algum, restando ao Estado, como vontade geral personificada, velar pela boa ordem social, mas sem intermediários entre ele e o povo, disperso e pulverizado ${ }^{80}$.

O golpe de misericórdia nas corporações de ofício é dado pela Revolução Francesa, responsável pela proclamação dos princípios da igualdade e da liberdade, hoje universalmente reconhecidos, que justificam o fim dos monopólios e privilégios até então assegurados às corporações de ofício. Após registrar o impacto provocado pelo referido acontecimento histórico, que entre outras coisas fez com que aprendizes e companheiros

\footnotetext{
${ }^{78}$ NOGUER, Héctor Humenes. Derecho del trabajo y de la seguridad social, tomo II: derecho colectivo del trabajo. $17^{\text {a }}$ ed. Santiago: 2005, p. 269.

${ }^{79}$ MORAES FILHO, Evaristo de. Do delito ao direito de greve - um quarto de século na vida italiana. Rio de Janeiro: Serviço de documentação do M. T. I. C., 1956, p . 8.

${ }^{80}$ Ibidem.
} 
passassem a desconhecer a autoridade de seus mestres, iniciando uma luta brutal e desleal entre eles, Héctor Humeres Noguer faz a seguinte observação:

No obstante el triunfo que significo la Revolución Francesa, en sus aspectos políticos, jurídicos y sociales, este no fue, como pudiera creerse, para la clase social más débil, los asalariados; no, ella fue obra del tercer estado, el triunfo de la burguesia, de la economia capitalista que imponía nuevas fórmulas sobre los viejos moldes feudales.

Esta nueva clase triunfante tuvo interés em mantener desorientada a la masa trabajadora y no permitir que se organizara socialmente - como lo estava em las corporaciones - ni en forma libre, como en la coalición. En el año 1791 se dictó la Ley Le Chapellier, que prohibió las asociaciones profesionales y considero delito a la huelga. Otros textos posteriores recogieron estes conceptos y los mantuvieron vigentes hasta la última parte del siglo pasado; pueden citarse: en Inglaterra, la Combination Law, 1799; Código Francês de Napoleón, de 1810; Código Español de 1843; Código Português, de 1852, y Código Sardo, de $1859^{81}$;

Este momento histórico é marcado pelas jornadas excessivas de trabalho; pela reunião de trabalhadores livres na cidade, a maioria ex-integrantes de corporações de ofício, com trabalhadores vindos do campo, de homens com mulheres e crianças; pelo pagamento escasso; pela aglomeração de trabalhadores nas cidades ao redor das primeiras grandes fábricas e, pela substituição do mestre chefe do atelier por um empregador totalmente estranho aos trabalhadores. Agregue-se a isto o fato de o desenvolvimento da indústria a vapor haver produzido uma enorme mobilidade da fonte de trabalho e um crescente desemprego o que, por sua vez, provocou um aumento na competição entre os que ofereciam seus braços aos que tinha interesse em ocupá-los ${ }^{82}$.

Neste contexto, a greve surge com a feição de simples fato jurídico, em um momento em que as diversas legislações ainda desconheciam o signficado de acordo ou concertação coletiva. Em seus primeiros momentos históricos o direito só aceitava as relações trabalhistas individuais e uma greve correspondia, sob a ótica então vigente, à cessação das obrigações de trabalhador. O conceito de liberdade desenvolvido a partir do fim da escravidão assevera que ninguém pode ser obrigado a trabalhar, mas sanciona quem abandona o trabalho responsabilizando-o pelos danos que seu abandono provoque ao

\footnotetext{
${ }^{81}$ NOGUER, Héctor Humenes. Derecho del trabajo y de la seguridad social, tomo II: derecho colectivo del trabajo. $17^{\mathrm{a}}$ ed. Santiago: 2005, pp. 269/270.

${ }^{82}$ NOGUER, Héctor Humenes. Derecho del trabajo y de la seguridad social, tomo II: derecho colectivo del trabajo. $17^{\mathrm{a}}$ ed. Santiago: 2005, p. 270.
} 
empregador e que este o substitua por outro mais comprometido com os seus objetivos. Os mais extremados liberais individualistas defenderam a greve com esta conotação, como um fenômeno similar à livre concorrência ou integrante dela. Os trabalhadores que abandonavam suas funções eram substituídos por outros, tarefa simples nos períodos em que a força de trabalho era abundante e a organização sindical ainda muito débil ${ }^{83}$.

Wilson de Campos Batalha observa com bastante felicidade que a greve, enquanto problema social e humano fundamental, só poderia ser examinada e compreendida, contida, regulamentada ou coibida sob o ângulo visual de uma concepção basilar da sociedade, do indivíduo e do Estado. No individualismo liberal o indivíduo abstrato, átomo social, era o valor fundamental, colocando-se acima da sociedade e do Estado, razão pela qual deveria se colocar perante este sem intermediários que poderiam ressuscitar as velhas corporações. Essa seria a razão pela qual durante o período de predomínio dessa doutrina, as coalizões, como agrupamentos eventuais, eram proibidas e os sindicatos, como agrupamentos permanentes, só poderiam ser considerados como acontecimento amorfo, plúrimo, sem unidade e sem objetivo algum ${ }^{84}$.

Neste período, prevalecia a ideia de que "se a greve de cada um pode harmonizarse com a liberdade dos demais, se pode generalizar-se, atende ao critério de moralidade. Mas, seria imoral a liberdade que implicasse denegação da liberdade de outro ou de outros". Valia a máxima "quem quiser trabalhar, que trabalhe. Quem não quiser trabalhar, que se abstenha mas não cerceie a liberdade dos que quiserem trabalhar". A greve era então erigida em apanágio da liberdade individual, descaracterizada como fenômeno coletivo $^{85}$.

A célebre Loi Le Chapelier declarou a absoluta ilegalidade de todas as coalizações, fossem quais fossem os seus objetivos e as suas formas, como o escopo de tentar impedir, politicamente, o retorno às ultrapassadas tradições do corporativismo. Teria, portanto, sido em nome da liberdade, tão decantada pelo individualismo jurídico e político, que teria se iniciado a luta contra as greves, como fruto de coalizões ou entendimentos temporários,

\footnotetext{
${ }^{83}$ ARTEAGA, William Thayer e FUENZALIDA, Patricio Novoa. Manual de derecho del trabalho, tomo I, Generalidades, Derecho Colectivo del trabajo. $5^{\text {a }}$ edición. Santiago: 2007, p. 175.

${ }^{84}$ BATALHA, Wilson de Souza Campos. Sindicatos, sindicalismo. São Paulo: LTr, 1992, p.203.

${ }^{85}$ BATALHA, Wilson de Souza Campos. Sindicatos, sindicalismo. São Paulo: LTr, 1992, p.204.
} 
que poderiam criar clima propício ao restabelecimento de velhas instituições ${ }^{86}$. Como resume Wilson de Souza Campos Batalha:

\begin{abstract}
A proibição das greves assumia um sentido político indisfarçável. Poderiam elas constituir, pela reunião de trabalhadores, unidos por idênticos interesses, numa única postulação global, o nascedouro de movimentos corporativistas que procurassem destruir os princípios básicos do individualismo revolucionário, que colocava o indivíduo (considerado atomisticamente e abstratamente, o 'homem geométrico') diretamente perante o Estado, sem organismos sociais intermediários que pudessem atentar contra a liberdade do trabalho ${ }^{87}$.
\end{abstract}

$\mathrm{Na}$ medida em que os conflitos laborais foram se tornando mais freqüentes e as coalizões deram origem a associações sindicais que concertavam sua ação, pressionando por meio da greve, esta foi se destacando como ato jurídico, vale dizer, como fato jurídico voluntário, realizado com a específica intenção de pressionar para modificar as condições do contrato de trabalho. Não obstante a legislação derivada da Revolução Francesa a considerasse ilícita e delituosa, advogava-se a possibilidade de greve com a tese segundo a qual "lo que no era delictual ejecutado por uma persona, no podría serlo si lo realizaba un grupo" ${ }^{88}$. Esta tese, no entanto, não impediu que os movimentos paredistas fossem tipificados como infrações penais na maioria dos países ocidentais o que, segundo parte da doutrina, influenciou ainda o desenvolvimento de doutrinas revolucionárias, principalmente o comunismo, para o qual a greve era um instrumento de luta de classes que preparava os trabalhadores para a greve geral, que provocaria a queda dos governos capitalistas e sua substituição pelo socialismo e pela sociedade sem classes ${ }^{89}$.

Neste período prevalecia aquilo que Batalha considerava concepção transpersonalista, que considera o indivíduo, a sociedade e o Estado a serviço da Cultura, acima dos tempos e das fronteiras nacionais. Teria sido esta concepção transpersonalista a característica marcante das ideologias totalitárias da direita e da esquerda. Teria ela se apresentado como o grande problema político, social e humano do século XX, provocando guerras e devastações, para diluir-se num esgotamento inglório no final do século em questão ${ }^{90}$.

\footnotetext{
${ }^{86}$ Ibidem, p.208.

${ }^{87}$ Ibidem, p. 209.

${ }^{88}$ ARTEAGA, William Thayer e FUENZALIDA, Patricio Novoa. Manual de derecho del trabalho, tomo I, Generalidades, Derecho Colectivo del trabajo. $5^{\text {a }}$ edición. Santiago: 2007, p. 175.

${ }^{89}$ ARTEAGA, William Thayer e FUENZALIDA, Patricio Novoa. Manual de derecho del trabalho, tomo I, Generalidades, Derecho Colectivo del trabajo. $5^{\text {a }}$ edición. Santiago: 2007, p. 175.

${ }^{90}$ BATALHA, Wilson de Souza Campos. Sindicatos, sindicalismo. São Paulo: LTr, 1992, p.205.
} 
Este pensamento transpersonalista procurava, nos dizeres de Batalha, "jugular os trabalhadores, alimentando-os com sonhos 'filosóficos' de uma cultura totalitária que implicava denegação, não apenas dos valores sociais, mas também dos mais elementares valores humanos". Essa seria a razão pela qual, dentro dessa diretriz, que sopesava os direitos básicos do trabalhador, não haveria admissibilidade para o reconhecimento do direito de greve. Essa seria a razão pela qual era ele capitulado como crime à organização do trabalho, à econômica nacional e contrário ao sentido transpersonalístico do trabalho ${ }^{91}$.

Com a Convenção de Chapultepec no México, em meados dos anos 40, o direito do trabalho incorpora definitivamente a greve com um de seus principais elementos. As empresas passam então a ter que considerar os meios através dos quais o conjunto ou coletividade de trabalhadores poderia defender condições humanas e equitativas de trabalho, negando-se coletivamente a seguir trabalhando se seus pedidos não eram atendidos. Com o desenvolvimento da organização sindical e o avanço das doutrinas sociais, não foi mais possível aos empresários ignorar simplesmente as reivindicações dos trabalhadores e substituí-los por outros. Não fosse isto o bastante, o trabalho se tornou mais técnico e qualificado, a força laboral tornou-se elemento importante para uma boa administração, não apenas por razões morais, como também por razões econômicas e de conveniência. O direito passou a proteger este interesse social, "que no sólo fue interés de los trabajadores, sino de la empresa toda y de la actividad productiva em general" 92 .

O escorço histórico traçado até aqui se identifica com a tradicional divisão do direito de greve em três períodos bem diferenciados, o da proibição e tipificação como um delito, o da permissibilidade, porém sujeita as regras de direito privado, e finalmente, a

\footnotetext{
${ }^{91}$ Idem. Na mesma obra há uma interessante abordagem sobre o direito de greve em alguns regimes totalitaristas. Batalha destaca, por exemplo, citando Pierre Lavigne, que "Na Alemanha nacional-socialista, orientada por filosofia supra-individualista de origens hegelianas, não haveria lugar para o direito de greve. Os direitos coletivos dos trabalhadores resumiam-se em aderir, ou não, à Arbeitsfront, como a liberdade política se limitava a inscrever-se, ou não no partido" (p. 211). Na URSS, o festejado autor brasileiro, citando Boris Topornín, destaca que a Constituição de 1977 "reforça o papel e a importância das organizações sociais no sistema político da sociedade. Em outras palavras, as organizações sociais dos trabalhadores acham-se vinculadas ao sistema e à estrutura política, não se admitindo movimentos de greve" (p. 212). Na China, o autor destaca que a "a democracia ditatorial não comporta direito de greve". E aduz que "Apesar das Cortes Populares e das Procuradorias populares, que pretendem disciplinar as contendas em sentido igualitário, não paira dúvidas de que os trabalhadores se acham estritamente vinculados ao poder do Estado" (p.212/213).

${ }_{92}$ ARTEAGA, William Thayer e FUENZALIDA, Patricio Novoa. Manual de derecho del trabalho, tomo I, Generalidades, Derecho Colectivo del trabajo. 5a edición. Santiago: 2007, p. 203.
} 
fase do reconhecimento como um direito, por vezes constitucionalmente assegurado ${ }^{93}$. O primeiro período seria marcado pela transição entre o regime artesão e o industrial. Nesta época a greve se justifica, sobretudo, porque os trabalhados constatam que a liberdade política que adquiriram, inspirada nos ideais da Revolução Francesa, lhes teria deixado em uma suposta e irreal igualdade jurídica com os empregadores. E que isto findava por sujeitar-lhes às duras condições de trabalho impostas pela nova classe social, a burguesia, especialmente no tocante à extensão das jornadas de trabalho ${ }^{94}$.

No segundo período, que se prolonga do último quarto do século XIX até o término da Primeira Guerra Mundial, em pleno século XX, o direito de greve é admitido como regra geral dentro do Direito Privado, primeiro, e como manifestação do direito de associação profissional depois, com a única limitação de se proibir a violência, que era reprimida quando se manifestava com um delito ${ }^{95}$.

O terceiro período, que transcorre entre as duas guerras mundiais do século passado, caracteriza-se em razão de um dos três interessados na greve, o Estado, ter passado a atuar como empregador ou associado com este em diversas atividades, devido ao intervencionismo praticado durante o desenvolvimento da Primeira Guerra Mundial e passado a suportar o exercício do direito de greve contra seus interesses ${ }^{96}$.

Cabe ainda destacar que alguns doutrinadores têm identificado um quarto momento histórico, no qual o Estado participa de forma ativa como empresário nos serviços ou empresas fiscais ou dentro do sistema de economia mista, serviços semifiscais (agências reguladoras), sofre na própria carne as conseqüências desta arma esgrimida pelos trabalhadores que já não distinguem entre empregador particular ou estatal e que em certos casos, dirigem sua ação diretamente contra o Estado, nas greves políticas ou de solidariedade ${ }^{97}$.

\footnotetext{
${ }^{93}$ Neste sentido são as lições de Ari Possidônio Beltran: "É de se observar que a divisão clássica de tais fases abrange os três grandes períodos, a saber: a greve como "delito", a greve como "liberdade" e a greve como "direito", os quais correspondem basicamente às fases que marcaram a evolução histórica do próprio sindicalismo (BELTRAN, Ari Possidônio. A autotutela nas relações de trabalho. São Paulo: LTr, 1996, p. 210.

${ }_{94}$ NOGUER, Héctor Humenes. Derecho del trabajo y de la seguridad social, tomo II: derecho colectivo del trabajo. $17^{\mathrm{a}}$ ed. Santiago: 2005, p. 271.

${ }^{95}$ Ibidem.

${ }^{96}$ NOGUER, Héctor Humenes. Derecho del trabajo y de la seguridad social, tomo II: derecho colectivo del trabajo. $17^{\mathrm{a}}$ ed. Santiago: 2005, p. 271.

${ }^{97}$ Ibidem.
} 
Em verdade, o movimento trabalhador emerge da Primeira Guerra Mundial, com enorme força, tendo, os países aliados, lhes permitido celebrar convenções internacionais as vésperas do armistício, aceitado suas conclusões e se comprometido a legislar em seu favor no Tratado de Paz (Conferência de Leeds, em 1916; Carta de Berna em 1918, e Conferência Preliminar de Paz, em 1919). Os partidos políticos, em especial os socialistas e comunistas, começam a utilizar a greve para confirmar suas teorias, fazendo-a deixar de ser uma ferramenta apenas para influir nas condições de trabalho. A classe trabalhadora se propõe a, mediante sua utilização, influir na gestão da empresa, no campo econômico e posteriormente no campo político nacional. Aparecem a greve política e de solidariedade e, por último, a greve geral ${ }^{98}$.

Percebe-se, de imediato, uma reação do Estado. Até este mesmo instante, salvo nos escassos países em que se proibia a greve (Austrália, Alemanha, Itália, Portugal, Espanha), a grande maioria havia reconhecido expressamente o direito de greve, seja em seus textos constitucionais, seja em seus textos legais. E são justamente estes que, a partir daquele momento passarão a ditar uma série de leis restritivas do uso do direito de greve, seja proibindo a greve geral, como fizeram Inglaterra e Dinamarca, seja proibindo greves em indústrias de utilidade pública, como fizeram Estados Unidos e Canadá, proibições que seriam manifestação de estatismo dessas nações ${ }^{99}$.

Este período final se vê interrompido pela Segunda Guerra Mundial, em que os Estados beligerantes, que precisamente foram os de maior desenvolvimento industrial, se vêem novamente obrigados a intervir e, ainda mais, a expropriar e socializar algumas indústrias. Ao seu término se percebe com maior clareza que o Estado lentamente vai substituindo ao empregador particular como sujeito passivo da greve, em alguns casos por ser também empresário ou associado com particulares, caso das empresas públicas e sociedades de economia mista, ou se tratar de um serviço que lhes cabe fiscalizar, por meio de suas agências reguladoras, ou ainda por se referir à greve com fins políticos. Este fato se verifica especialmente nos países democráticos em que as forças que chegaram ao poder são de esquerda ou compostas por elementos populares, como é o caso de França e Itália. Como arremata Héctor Humeres Noguer, "los Estados reaccionam y lo hacen por cauces

\footnotetext{
${ }^{98}$ Ibidem.

${ }^{99}$ Ibidem.
} 
legales; nuevas limitaciones vienen a sumarse a las ya existentes para el ejercício de este derecho $^{100}$.

\subsection{ASPECTOS HISTÓRICOS DO DIREITO DE GREVE NO BRASIL}

A abolição tardia da escravidão no Brasil, em 1888, foi logo seguida por uma legislação penal (Decreto n. 847, de 11 de outubro de 1890) que proibia a greve, tipificando-a como ilícito penal nos artigos 205 e 206.

Antonio Rodrigues de Freitas Júnior aponta como característica mais evidente dos conflitos de classe havidos na I República, a dificuldade em se ajustarem ao edifício institucional da ordem liberal. Em sua leitura, um dos mais importantes suportes da retórica estadonovista, a bem dizer, de todo o discurso ideológico voltado à legitimação de modelos de Estado superfetado e de Nação organicamente idealizada, foi o mito da "inviabilidade" do liberalismo para o Brasil ${ }^{101}$.

O mesmo autor destaca ainda que a intimidade das relações entre o empresariado e os órgãos policiais não teve uma dimensão meramente episódica. Seus estudos o permitiram concluir que este período foi marcado pela compilação de um elenco nada desprezível de engenhosos mecanismos para vigília e repressão à atividade sindical dos trabalhadores. Entre estes mecanismos estariam a utilização de uma "lista negra" destinada ao arrolamento dos "agitadores profissionais", a instituição de Dossiês de todos os trabalhadores, em que se fizesse registrada e valorizada a vida profissional destes e a padronização dos instrumentos de contrato individual de trabalho. O mesmo autor menciona ainda que a própria constituição de algumas das associações patronais esteve ligada à necessidade de definição de uma conduta unificada no emprego de "meios práticos para solucionar as greves" 102 .

Freitas Júnior destaca ainda que em nossa primeira experiência republicana, a recusa das camadas dirigentes em conferir mecanismos que assegurassem eficácia aos

\footnotetext{
${ }^{100}$ NOGUER, Héctor Humenes. Derecho del trabajo y de la seguridad social, tomo II: derecho colectivo del trabajo. $17^{\mathrm{a}}$ ed. Santiago: 2005, p. 272.

${ }_{101}$ FREITAS JÚNIOR, Antonio Rodrigues de. Sindicato: domesticação e ruptura: um estudo da representação sindical no direito brasileiro. São Paulo: Ordem dos Advogados do Brasil, Departamento Editorial, 1989, p. 40/41.

102 FREITAS JÚNIOR, Antonio Rodrigues de. Sindicato: domesticação e ruptura: um estudo da representação sindical no direito brasileiro. São Paulo: Ordem dos Advogados do Brasil, Departamento Editorial, 1989, p. 39.
} 
acordos coletivos de trabalho, motivada em parte pelo apego ao liberalismo bacharelesco, aliada à vigorosa resistência empresarial frente aos sindicatos de trabalhadores, comprometeu a possibilidade de uma aproximação tangível entre os espaços "civis" e "públicos" da liberdade. Isso possibilitou a criação e manutenção de um tecido institucional capaz de assegurar um processo de progressiva acumulação de conquistas das camadas subalternas que deslocava a expectativa e os métodos reivindicatórios da "ação direta" para o exterior das fronteiras políticas do assentimento, revigorando um ciclo de marginalidade para os conflitos sindicais ${ }^{103}$.

Afirma, em remate, que o Estado corporativista não poderia prescindir do monopólio da nomogênese, além do da não violência. Definindo-se como depositário de ambas as "liberdades", o poder constituído desestimulava todas as fontes de direito que pudessem evadir aos meridianos de sua providência. Não obstante conferisse estatuto de juridicidade à convenção coletiva, findava por subordinar seus limites objetivos à mera declaração ou complementação do patrimônio jurídico antecipadamente delimitado na versão estatal do "interesse público", do "bem comum", da "vontade geral" e dos “objetivos nacionais". Assimilando a positivação das garantias jurídicas às camadas subalternas, e malgrado essas últimas, o mito da "outorga" funcionaria como elemento galvanizador de suas expectativas por melhorias trabalhistas, que passariam a ser, doravante, veiculadas sob a forma de postulação no terreno da disputa estritamente jurídica $^{104}$.

Amauri Mascaro Nascimento, por sua vez, destaca que a inexistência de lei disciplinando os movimentos grevistas neste momento da história republicana do Brasil funcionava como uma faca de dois gumes. Se por um lado ela permitia o seu exercício sem restrições, por outro ela tolerava uma excessiva intervenção do Estado ${ }^{105}$.

Diferentemente das Constituições brasileiras de 1824 e 1891, que silenciaram acerca do direito de greve, a Carta Magna de 1937 considerou livre a associação profissional ou sindical, em seu art. 138, e proibiu, categoricamente, as greves e os lockouts (ou locautes), em seu artigo 139 que dispunha que "a greve e o lock-out são

\footnotetext{
${ }^{103}$ Ibidem, p. 45.

104 FREITAS JÚNIOR, Antonio Rodrigues de. Sindicato: domesticação e ruptura: um estudo da representação sindical no direito brasileiro. São Paulo: Ordem dos Advogados do Brasil, Departamento Editorial, 1989, p. 49.

${ }^{105}$ NASCIMENTO, Amauri Mascaro. Compêndio de direito sindical. $4^{\mathrm{a}}$ ed. São Paulo: LTr, 2005, p. 466.
} 
declarados recursos antissociais, nocivos ao trabalho e ao capital e incompatíveis com os superiores interesses da produção nacional".

Sob a égide deste texto constitucional foi editado o Decreto-lei n. 431, de 18 de maio de 1938, que tipificou como delitos penais as condutas consistentes em "incitar diretamente o ódio entre as classes sociais ou instigá-las à luta pela violência" e "induzir empregadores ou empregados à cessação ou suspensão do trabalho". O Decreto-lei n. 869, de 18 de novembro do mesmo ano, definiu como crime contra a economia popular os atos de "abandonar ou fazer abandonar lavouras ou plantações, suspender ou fazer suspender a atividade de fábricas, usinas ou quaisquer estabelecimentos de produção ou meios de transporte, mediante indenização paga pela desistência da competição".

Pouco mais de dois anos depois, mais precisamente em 7 de dezembro de 1940, foi editado o Decreto- lei n. 2.848 (Código Penal), que incluiu entre os crimes contra a organização do trabalho "constranger alguém, mediante violência ou grave ameaça, a abrir ou fechar o seu estabelecimento de trabalho, ou a participar de parede ou paralisação de atividade econômica"106, "participar de suspensão ou abandono coletivo de trabalho, praticando violência contra pessoa ou coisa"107, "participar de suspensão ou abandono coletivo de trabalho praticando violência contra pessoa ou coisa"108, "invadir ou ocupar estabelecimento industrial, comercial ou agrícola, com o intuito de impedir ou embaraçar o curso normal do trabalho, ou com o mesmo fim danificar o estabelecimento ou as coisas nele existentes ou delas dispor ${ }^{109,}$.

Posteriormente, o Decreto-lei 4.766, de $1^{\circ}$ de outubro de 1942, tipificou como crime participar de supensão ou abandono coletivo de trabalho, em centro industrial, a serviço de construção ou de fabricação destinada a atender às necessidades da defesa nacional, praticando violência contra a pessoa ou coisa.

Como bem observa Wilson de Souza Campos Batalha, nesse momento histórico a greve e o lock-out eram previstos como crime comum, como crime contra a segurança do

\footnotetext{
106 Art. 197.

107 Art. 200.

${ }^{108}$ Art. 201.

${ }^{109}$ Art 202.
} 
Estado e como crime contra a economia popular e ainda eram sancionados por dispositivos legais de ordem trabalhista ${ }^{110}$.

A Consolidação das Leis do Trabalho (Decreto-lei n. 5.452, de $1^{\circ}$ de maio de 1943) tratava na Seção I, Capítulo VII, do lockout e da greve, prevendo que os empregados que, coletivamente e sem prévia autorização do tribunal abandonassem o serviço, ou desobedecessem a qualquer decisão proferida em dissídio, incorreriam nas penalidades de suspensão ou dispensa do emprego, perda ou suspensão do direito de serem eleitos para o cargo de representação profissional (art. 723).

Pouco após a promulgação da Consolidação das Leis do Trabalho, mais precisamente, em 7.3.1945, foi aprovada a declaração de Princípios Sociais da América, também conhecida como Ata de Chapultepec ou Convenção de Chapultepec, a qual o Brasil aderiu.

O Decreto-lei n. 9.070, de 15 de março de 1946, dispunha sobre a suspensão ou abandono coletivo do trabalho, sendo considerada a nossa primeira lei ordinária sobre greve, admitindo-a nas atividades acessórias. Influenciado pela Convenção de Chapultepec, o referido Decreto reconheceu a greve como um direito com limitações que somente poderia ser exercitado como ultima ratio, após esgotados os meios legais para remediar as suas divergências. Para se ter uma ideia, somente depois de ajuizado o dissídio coletivo na Justiça do Trabalho, a greve poderia ser deflagrada (art. $9^{\circ}$ ) e a paralisação das atividades sem observância dos processos e prazos conciliatórios ou decisórios previstos na lei, por parte dos empregados em atividades acessórias e, em qualquer caso, em se tratando de atividades essenciais, era considerada falta grave para os fins devidos, autorizando a rescisão do contrato de trabalho com este fundamento (art. 10).

Não obstante fosse incompatível com o texto da Constituição de 1937, que expressamente proibia a greve, o Decreto Lei em vigor foi reputado constitucional pelo $\mathrm{STF}^{111}$.

Segundo Batalha, no período anterior ao mês de março de 1964, houve expressivo número de greves em que as reivindicações salariais vinham associadas a questões

\footnotetext{
${ }^{110}$ BATALHA, Wilson de Souza Campos. Tratado de direito judiciário do trabalho. São Paulo: LTr, 1985, p. 683 .

${ }^{111}$ CORTEZ, Julpiano Chaves. A lei de greve. São Paulo: LTr, 2010, p. 12.
} 
políticas ou de solidariedade. Neste momento o poder normativo da Justiça do Trabalho não podia exercer-se convenientemente em decorrência da falta de dados estatísticos seguros para apuração dos percentuais de reajuste salarial ${ }^{112}$.

A Lei n. 4.330 , de $1^{\circ}$ de junho de 1964 , que regulava o direito de greve previsto no artigo 158 da $\mathrm{CF} / 46$, passou, segundo Julpiano Chaves Cortez, a ser chamada de lei antigreve tantas eram as exigências para que a greve fosse considerada legal ${ }^{113}$. Basta dizer que a lei em questão considerava exercício da greve "a suspensão coletiva e temporária da prestação de serviços a empregador, por deliberação da assembleia geral de entidade sindical representativa da categoria profissional interessada na melhoria ou manutenção das condições de trabalho vigentes na empresa ou empresas correspondentes à categoria, total ou parcialmente, com a indicação prévia e por escrito das reivindicações formuladas pelos empregados", exigindo, portanto, um documento solene para a sua realização. Ele também restringia a greve aos empregados subordinados, haja vista que no artigo $3^{\circ}$ estipulava que só poderiam participar da greve "as pessoas físicas que prestem serviços de natureza não eventual a empregador, sob a dependência deste e mediante salário". As paralisações eram expressamente vedadas aos servidores públicos e precisavam ser autorizadas por decisão da assembleia geral da entidade sindical, que representasse a categoria profissional dos associados, por 2/3 (dois terços) em primeira convocação, e, por 1/3 (um terço), em segunda convocação, em escrutínio secreto e por maioria de votos. A lei disciplinava até as informações que deveriam conter nas convocações das assembleias gerais que precisavam ser publicadas nos jornais do local da situação da empresa. A notificação precisava ser feita por escrito assegurando-se o prazo de 5 (cinco) dias para a solução pleiteada pelos empregados, sob pena de abstenção pacífica e temporária do trabalho, a partir do mês, dia e hora mencionado na comunicação, com o interregno mínimo de 5 (cinco) dias nas atividades acessórias e de 10 (dez) dias nas atividades fundamentais.

Eram consideradas atividades essenciais aquelas ligadas aos serviços de água, energia, luz, gás, esgotos comunicações, transportes, carga ou descarga, serviço funerário, hospitais, maternidade, venda de gêneros alimentícios de primeira necessidade, farmácias e drogarias, hotéis e indústrias básicas ou essenciais à defesa nacional, além das chamadas

\footnotetext{
112 BATALHA, Wilson de Souza Campos. Tratado de direito judiciário do trabalho. São Paulo: LTr, 1985, p. 690 .

${ }^{113}$ CORTEZ, Julpiano Chaves. Op cit, p. 12.
} 
indústrias básicas ou essenciais à defesa nacional, conforme entendimento da presidência da república (art. 12). Essa discricionariedade presidencial na definição de atividades essenciais, própria de regimes autoritários, possibilitava ampla restrição ao direito de greve merecendo, por essa razão, uma crítica enfática.

Nos transportes (terrestres, marítimo, fluvial e aéreo) a paralisação do trabalho em veículos em trânsito e dos respectivos serviços, só será permitida após a conclusão da viagem, nos pontos terminais (Art. 13). Já nas atividades fundamentais que não pudessem sofrer paralisação, as autoridades competentes fariam guarnecer e funcionar os respectivos serviços (art. 14).

$\mathrm{O}$ aviso prévio nas atividades fundamentais e nas acessórias, quando motivado pela falta de pagamento de salário nos prazos previstos em lei ou pelo não cumprimento de decisão, proferida em dissídio coletivo, que tenha transitado em julgado, era de 72 horas.

A Constituição Federal, de 24 de janeiro de 1967, assegurava aos trabalhadores o direito de greve (art. 158, XXI), salvo nos serviços públicos e atividades essenciais (art. 157, § $7^{\circ}$ ). A Emenda à Constituição n. 1, de 17 de outubro de 1969, praticamente reproduziu, quanto a esta matéria, a de 1967, assegurando aos trabalhadores o direito de greve (art. 165, XXI), salvo nos serviços públicos e atividades essenciais (art. 162).

Algumas leis pontuais foram editadas para tratar do exercídio da greve em setores específicos. Enquanto a Lei n. 6.128/78 cuidou da proibição de greve nas autarquias e na administração pública direta, o Decreto-lei n. 1.632, de 4 a de agosto de 1978, tratava da proibição de greve nos serviços públicos e em atividades essenciais de interesse da segurança nacional.

Durante a ditadura militar, as manifestações grevistas foram duramente reprimidas, e graças a isso as fábricas podiam repetir o autoritarismo do regime, como observa Márcio Túlio Viana. $\mathrm{O}$ autor mineiro aduz ainda que a mais inocente conversa ou uma simples ida ao banheiro fora de hora valiam cartas de advertência, quando não suspensões e despedidas ${ }^{114}$. Sobre sua experiência como sindicalista durante este período, afirmou Luís Inácio Lula da Silva:

\footnotetext{
${ }^{114}$ VIANA, Márcio Túlio. Direito de resistência: possibilidades de autodefesa do empregado em face do empregador. São Paulo: LTr, 1996, p. 287.
} 
A Lei de Greve tinha sido alterada e impunha tantas exigências que na prática impediam que fosse utilizada essa arma, praticamente a única que os trabalhadores possuem quando as negociações chegam a um impasse. O Brasil tinha como principal atrativo para as empresas multinacionais os baixos salários que eram pagos aos nossos trabalhadores, o chamado arrocho salarial. E não podíamos abrir o bico para reclamar. $\mathrm{O}$ jeito foi forçar a barra e realizar as paralisações sem pedir licença, fazendo valer um direito legítimo, embora não fosse legal. A nossa luta por melhores salários e melhores condições de trabalho não poderia abrir mão desse instrumento ${ }^{115}$.

A Constituição Federal, de 5 de outubro de 1988, assegura o direito de greve aos trabalhadores do setor privado, inclusive os empregados das empresas públicas e das economias mistas (art. $9^{\circ} \mathrm{c} / \mathrm{c} 173, \S 1^{\circ}$, II). Na administração pública direta e indireta (autarquias e fundações públicas), o direito de greve será exercido nos termos e nos limites definidos em lei específica (art. 37, VII). Ao militar são proibidas a sindicalização e a greve (art. 142, V).

Finalmente foi editada a Lei n. 7.783, de 28 de junho de 1989, que regulamentou o exercício do direito de greve na iniciativa privada, dispondo sobre o atendimento das necessidades inadiáveis da comunidade, compatibilizando o direito de greve com outros direitos constitucionais, como o direito à vida, à liberdade, à igualdade, à segurança e à propriedade (art. $5^{\circ}$, caput).

\subsection{DIREITO DE GREVE EM ALGUMAS EXPERIÊNCIAS EXTRANGEIRAS}

Não obstante não existam convenções e recomendações da OIT tratando expressamente do direito de greve, há duas resoluções da própria Conferência Internacional do Trabalho (CIT), responsável pelas diretrizes para política da OIT, insistindo no reconhecimento do direito de greve nos Estados Membros. A Resolução sobre a abolição da legislação antissindical nos Estados membros da OIT, adotada em 1967, instava a adoção de uma "legislação que assegure o exercício efetivo e sem restrição alguma dos direitos sindicais por parte dos trabalhadores, inclusive o direito de greve". A resolução sobre direitos sindicais e sua relação com as liberdades civis, por sua vez,

${ }^{115}$ MINISTÉRIO DO TRABALHO E EMPREGO. Revista Trabalho. Brasília: 2010, p. 36. Disponível em formato eletrônico no sítio <http://www.mte.gov.br/revista/edicao_80anos/revista.pdf\#page=27>. Acesso em $02 / 01 / 11$. 
adotada em 1970, convidou o Conselho de Administração a recomendar ao Diretor-Geral uma série de iniciativas "que considerassem novas medidas com vista ao pleno e universal respeito dos direitos sindicais em seu sentido mais amplo", dispensando especial atenção, entre outros, ao direito de greve $\mathrm{e}^{116}$.

Bernard Gernigon, Alberto Odero e Horarcio Guido observaram, em publicação oficial da Organização Internacional do Trabalho (OIT), que data de 2002, que a Comissão de Aplicação das Normas da OIT tem-se distinguido pelo consenso com relação ao princípio do direito de greve; não obstante não sejam coincidentes os pontos de vista do Grupo de Trabalhadores, do Grupo de Empregadores e dos membros governamentais. O primeiro grupo apoia totalmemente o enfoque da Comissão de Peritos sobre o direito de greve e o considera um corolário inseparável do direito de associação sindical protegido pela Convenção 87 e pelos princípios enunciados na Constituição da OIT. O Grupo de Empregadores, por sua vez, considera que o direito de fazer ações diretas poderia talvez ser reconhecido como parte do direito internacional consuetudinário e, nessas circunstâncias, deveria ser rejeitada a total proibição desse direito ou só autorizado sob determinadas condições excessivamente restritivas. O Grupo dos membros governamentais, por fim, tem ressaltado que as Convenções 87 e 98 não contêm disposições específicas sobre o direito de greve e, por isso, não aceita que a Comissão de Peritos deduza do texto dessas convenções um direito global, preciso e detalhado, absoluto e ilimitado ${ }^{117}$.

O Comitê de Liberdade Sindical da Organização Internacional do Trabalho considera o direito de greve um direito legítimo ao qual podem recorrer os trabalhadores e suas organizações em defesa de seus interesses econômicos e sociais ${ }^{118}$, constituindo ainda um dos meios essenciais de que dispõem para promover e defender seus interesses profissionais ${ }^{119}$ e um corolário indissociável do direito de sindicalização protegido pela

${ }^{116}$ ORGANIZAÇÃO INTERNACIONAL DO TRABALHO. A greve: o direito e a flexibilidade. Brasília: Organização Internacional do Trabalho, 2002, p. 17.

${ }^{117}$ Ibidem, p. 19.

${ }^{118}$ Precedente 521 da $5^{\text {a }}$ edição da Recopilación de decisiones y princípios del Comité de Libertad Sindical del Consejo de Administración de la OIT que assim dispõe: El Comité ha reconocido siempre el derecho de "huelga como un derecho legítimo al que pueden recurrir los trabajadores y sus organizaciones en defensa de sus intereses económicos y sociales". (Véanse Recopilación de 1996, párrafo $474 \mathrm{y}$, por ejemplo 302. ${ }^{\circ}$ informe, caso núm. 1809, párrafo $381 ; 304 .^{\circ}$ informe, caso núm. 1863 , párrafo $356 ; 307 .^{\circ}$ informe, caso núm. 1850, párrafo 120; $308 .^{\circ}$ informe, caso núm. 1900, párrafo 183; 311.er informe, caso núm. 1934, párrafo 126; $324 .^{\circ}$ informe, caso núm. 2072, párrafo $587 ; 327 .^{\circ}$ informe, caso núm. 1581 , párrafo $111 ; 328 .^{\circ}$ informe, caso núm. 2116, párrafo $368 ; 332 .^{\circ}$ informe, caso núm. 2258, párrafo 522 y $335 .^{\circ}$ informe, caso núm. 2305 , párrafo 505.)

${ }_{119}$ Precedente 521 da 5 a edição da Recopilación de decisiones y princípios del Comité de Libertad Sindical del Consejo de Administración de la OIT que assim dispõe: "El derecho de huelga de los trabajadores y sus 
Convenção n. 87, o que, aliás, justifica um procedimento de denúncia específico que será estudado em item posterior ${ }^{120}$.

A importância dada, portanto, pela OIT ao direito de liberdade sindical demonstra, em alguma medida, a relevância do direito de greve. Segundo Oscar Ermida Uriarte, se deve à OIT a precedência no tempo - e por muito tempo, por quase trinta anos, do reconhecimento internacional da liberdade sindical e outros direitos laborais. Quando em 1948 a Conferência Geral da OIT aprovou a Convenção Internacional n. 87 sobre liberdade sindical, esta se converteu no primeiro dos direitos fundamentais a ser reconhecido, consagrado e regulado em um tratado internacional específico, dedicado a um único dos direitos humanos ${ }^{121}$.

Homero Batista Mateus da Silva observa, com grande acerto, que a Organização Internacional do Trabalho sempre teve que ser cautelosa ao tratar do direito de greve, haja vista que nem todos os países atingiram consenso sobre a natureza jurídica da greve como um direito do trabalhador. Como até recentemente a natureza de delito permanecia em grande parte dos países da antiga Cortina de Ferro, que a tomavam como um comportamento nocivo à sociedade e bloqueavam as votações sobre o tema no seio da referida organização, jamais houve a elaboração de uma convenção ou de uma recomendação especificamente sobre a matéria. Ademais, a OIT teve de passar a usar a expressão "recurso à greve" e não "direito à greve", a fim de conciliar a maioria dos interesses. Diante do dilema da falta de consenso sobre a elaboração de um tratado em torno do "recurso de greve", a OIT foi aos poucos inserindo o tema em diversos textos, como a Recomendação 92 (1951), que discorre sobre arbitragem voluntária, proibindo que seu uso sirva de obstáculo à greve; a Convenção 105 (1957), que bane trabalhos forçados, inclusive aqueles decorrentes de castigo por participação em greve; a Convenção 160 e a

\footnotetext{
organizaciones constituye uno de los medios esenciales de que disponen para promover y defender sus intereses profesionales”.(Véanse Recopilación de 1996, párrafo 475 y, por ejemplo 299. ${ }^{\circ}$ informe, caso núm. 1687, párrafo $457 ; 300 .^{\circ}$ informe, caso núm. 1799 , párrafo $207 ; 306^{\circ}$ informe, caso núm. 1884, párrafo 695 ; 308. ${ }^{\circ}$ informe, caso núm. 1934, párrafo $131 ; 310{ }^{\circ}$ informe, caso núm. 1928, párrafo $176 ; 316^{\circ}$ informe, caso núm. 1930, párrafo $365 ; 327 .^{\circ}$ informe, caso núm. 1581 , párrafo $111 ; 3300^{\circ}$ informe, caso núm. 2196, párrafo 304; 335 . $^{\circ}$ informe, caso núm. 2257, párrafo $466 ; 336 .^{\circ}$ informe, caso núm. 2340 , párrafo 645 y $337 .{ }^{\circ}$ informe, caso núm. 2365, párrafo 1665 .)

${ }^{120}$ Precedente 523 da $5^{\text {a }}$ edição da Recopilación de decisiones y princípios del Comité de Libertad Sindical del Consejo de Administración de la OIT que assim dispõe: "El derecho de huelga es corolario indisociable del derecho de sindicación protegido por el Convenio núm. 87". (Véase 311. ${ }^{\circ}$ informe, caso núm. 1954, párrafo 405)

${ }_{121}$ ERMIDA URIARTE, Oscar. Critica de la libertad sindical. Derecho Laboral - Tomo IV, n. 242, abriljunio 2011, p. 230.
} 
Recomendação 175 (1985), que estipulam formas de estatísticas trabalhistas e exigem que todos os conflitos laborais sejam computados, inclusive as greves; e a Recomendação 176 (1985), que prevê indenização pelo desemprego involuntário, mas esclarece que este não deve ser confundido com adesão a movimento grevista ${ }^{122}$.

Além destas rápidas referências, a OIT tem apresentado diretrizes acerca da melhor forma de interpretar o direito de greve nas decisões do Comitê de Liberdade Sindical, sobre o qual se discorrerá mais detalhadamente a seguir.

A Carta da Organização dos Estados Americanos assegurou, em seu artigo 45, c, o direito de empregadores e de trabalhadores, tanto rurais como urbanos, se associarem livremente para a defesa e promoção de seus interesses, inclusive o direito de negociação coletiva e o de greve por parte dos trabalhadores, relegando, contudo, a normatização para a sua respectiva legislação ${ }^{123}$.

A Declaração sócio-laboral do Mercosul, por sua vez, assegurou a todos os trabalhadores e organizações sindicais o exercício do direito de greve, conforme as disposições vigentes. Asseverou em seguida que os mecanismos de prevenção ou solução de conflitos ou a regulação deste direito não poderão impedir seu exercício ou desvirtuar sua finalidade.

Atualmente, o direito de greve é reconhecido até mesmo no ordenamento da União Européia. A Carta dos Direitos Fundamentais do aludido bloco internacional, que se tornou juridicamente vinculante a partir do Tratado de Lisboa, em vigor desde 1 de dezembro de 2009, reconhece uma pluralidade de direitos fundamentais, entre os quais o direito de negociação coletiva e de greve. Com efeito, o artigo 28 da chamada Carta de Nizza, afirma textualmente que

Os trabalhadores e as entidades patronais, ou as respectivas organizações, têm, de acordo com o direito comunitário e as

\footnotetext{
${ }^{122}$ SILVA, Homero Mateus Batista da. Curso de direito do trabalho aplicado, vol. 7: direito coletivo do trabalho. Rio de Janeiro: Elsevier, 2010, p. 256.

${ }^{123}$ Art. 45. Os Estados membros, convencidos de que o Homem somente pode alcançar a plena realização de suas aspirações dentro de uma ordem social justa, acompanhada de desenvolvimento econômico e de verdadeira paz, convêm em envidar os seus maiores esforços na aplicação dos seguintes princípios e mecanismos: (...)

c) Os empregadores e os trabalhadores, tanto rurais como urbanos, têm o direito de se associarem livremente para a defesa e promoção de seus interesses, inclusive o direito de negociação coletiva e o de greve por parte dos trabalhadores, o reconhecimento da personalidade jurídica das associações e a proteção de sua liberdade e independência, tudo de acordo com a respectiva legislação;
} 
legislações e práticas nacionais, o direito de negociar e de celebrar convenções colectivas, aos níveis apropriados, bem como de recorrer, em caso de conflito de interesses, a acções colectivas para a defesa dos seus interesses, incluindo a greve $^{124}$.

Percebe-se, contudo, a partir do texto acima transcrito, que a União Européia reconhece o direito de ação coletiva como direito fundamental, mas não fornece uma regulamentação própria para o exercício deste direito, remetendo esta tarefa para os legisladores de cada um de seus estados membros. Gino Giugni corrobora esta conclusão ao afirmar, em obra atualizada por Lauralba Bellardi, Pietro Curzio e Mario Giovanni Garofalo, que o artigo 153 do Tratado da União Européia (correspondente ao artigo 127 do Tratado da Comunidade Européia) reconhece a competência exclusiva do legislador nacional para tratar do referido tema ${ }^{125}$.

Giovanni Orlandini, entretanto, considera precária a preocupação da União Européia com o Direito de Greve. Em suas palavras, "Nonostante il timido progresso fatti a Nizza, il diritto di sciopero non fa ancora parte a pieno titolo dei valori fondati l'Unione europea". Em sua opinião, o ordenamento comunitário não parece se libertar de um direito do trabalho que subordina as garantias dos trabalhadores à competitividade das empresas. Neste ordenamento o direito de greve permanece o mais vulnerável entre os direitos sociais justamente por ser irredutível à lógica da eficiência econômica. As poucas considerações que a greve teve no direito comunitário refletem a natureza predominantemente econômica da Constituição européia. A falta de um standard comunitário para a greve, justificada por questões de neutralidade humanitária e respeito pela prerrogativa nacional, princípios que norteiam a integração europeia, pode facilitar o processo de erosão do direito à greve que já viu ser implementadas na legislação nacional italiana ${ }^{126}$.

Após suas críticas, Orlandini destaca que a recondução do direito de greve, cujo exercício mostra-se fundamental para que se assegure o princípio da igualdade material, à categoria dos direitos sociais, exige que se reconheça a autoexecutoriedade do preceito da Carta Européia. Outrossim, não obstante não se coloque em questão a discricionariedade

\footnotetext{
${ }^{124}$ Disponível em: <http://www.europarl.europa.eu/charter/pdf/text_pt.pdf >. Acesso em 25 de dezembro de 2010.

${ }^{125}$ GIUGNI, Gino. Diritto sindacale. Aggiornato da Lauralba Bellardi, Pietro Cursio e Mario Giovanni Garofalo. Bari: Cacucci Editore, 2010, p. 235.

${ }^{126}$ ORLANDINI, Giovanni. Sciopero e servizi pubblici essenciali nel processo d'integrazione europea: uno studio di diritto comparato e comunitário. Torino: Giappichelli editore: 2003, p. 7.
} 
dos legisladores nacionais na definição de conteúdo do direito de greve, ou na necessidade de ajustar os meandros desta garantia para satisfazer as necessidades econômicas e financeiras dos trabalhadores locais, para assegurar alguma eficácia a este direito é preciso que todos os estados reconheçam que referido preceito consiste em uma regra e não em um princípio, e que ele é autoaplicativo, permitindo ao seu titular o direito de processar indivíduos que impeçam o seu exercício ${ }^{127}$.

A Carta Social Européia subscrita em 18 de outubro de 1961 pelos Estados membros do Conselho da Europa, assim como sua versão revista em 3 de maio de 1996, reconhece, em seu artigo $6, \S 4$, o princípio do direito de greve. Contudo, como o direito de greve não foi proclamado pela Convenção de salvaguarda dos direitos do homem e das liberdades fundamentais, a Corte Europeia de Direitos do Homem tende a solucionar a questão fundamentando a proteção aos movimentos grevistas no conceito mais amplo de liberdade sindical inscrito no artigo 11 da aludida Convenção ${ }^{128}$.

Adotada na Comunidade Europeia, a Carta comunicatária dos direitos sociais fundamentais dos trabalhadores de 9 de dezembro de 1989 dispõe, em seu parágrafo 13, sobre o direito recorrer à ações coletivas, entre elas a greve, em caso de conflitos de interesses. A Carta dos Direitos Fundamentais da União Européia de 6 de dezembro de 2000, por sua vez, afirma, em termos parecidos, que o direito dos trabalhadores "de recourir, en cas de conflits d'intérêts, à des actions collectives pour la défense de leurs intérêts, y compris la greve" (Art. 28) ${ }^{129}$.

\footnotetext{
127 "La riconduzione dello sciopero nella categoria dei diritti sociale dipende dal nesso strumentale che vi è tra il suo esercizio e il principio di eguaglianza sostanziale; il suo riconoscimento presuppone cioè uma desiguaglianza di fatto nel rapporto tra capitale e lavoro, ed uno status di debolezza socio-economico nel titolare, che con quel diritto s'intende, se non superare, almeno limitare. É per il fatto che "tiene conto" di tale status di debolezza socio-economica del titolare, che il diritto di sciopero è qualificato como "sociale", pur essendo la sua struturra giuridica la medesima dei diritti di libertá, per definizione "self-executing" (o, come detto, "incondizionati"). Come i diritto di libertá, Esso una volta inserito in Costituzione, non richiede la mediazione del legislatore per trovare concreta attuazione. Non si pone dunque nei confonti dello sciopero il problema dei limiti di discrezionalità del legislatore nel definirne il contenuto, né della necessità di modularne le garanzie in funzione di esigenze di carattere econômico-finanziario. Per richiamare categorie sopra evocate, si può dire che la norma che lo riconosce ponga uma regola, più che um principio, nella misura in cui contiene um precetto "autoapplicativo", che permette al titolare del diritto di agire in giudizio contro atti o comportamenti di privati che ne impescano l'esercizio. (ORLANDINI, Giovanni. Ibidem, p. 18) ${ }^{128}$ CEDH, 10 janv. Et 27 juin 2002: D. 2003, jurispr. P. 939, note J.-P. Marguénaud et J. Mouly. - Rappr. CEDH, 5 mars 2009: JCP S 2009, 1298, note J. Cavallini apud TEYSSIÉ, Bernard. Grève dans le secteur privé. Jurisclasseur Travail Traité, fasc. 70-10, 15 avril 2010. 129 Idem.
} 
A Constituição francesa expressamente prevê que a greve se exercerá na forma das leis que a regulamentam. Além de diversas normas proibindo manifestações grevistas em determinadas categorias ${ }^{130}$, cabe uma especial referência à Loi du 31 juillet 1963. Não obstante se intitule lei sobre as modalidades de greve nos serviços públicos ${ }^{131}$, ela trata também dos empregados civis dos diversos órgãos estatais, dos empregados de empresas privadas que prestem serviços públicos e de empresas públicas industriais e comerciais dotadas de um estatuto especial ${ }^{132}$. Como o legislador se absteve de interfervir no setor privado, as regras que governam o exercício do direito de greve são estabelecidas pelos juízes ${ }^{133}$.

A maioria dos Textos Constitucionais dos países ocidentais reconhece a greve como um direito. O de Portugal, por exemplo, o faz em seu artigo $57^{\circ}{ }^{134}$, a Grécia em seu artigo $23.2^{135}$, a Espanha em seu artigo $28.2^{136}$ e a Suécia em seu artigo $17^{137}$. Como bem

${ }^{130}$ Loi 13 juillet 1972; Loi 27 décembre 1947; Loi 28 septembre 1948, Ord. 6 août 1958, Ord.22 déc. 1958, loi de finances du 31 juillet 1978.

${ }^{131}$ Loi sur les modalities de la greve dans les services publics.

${ }^{132}$ Como salientam Jean Pélissier, Alain Supiot e Antoine Jeammaud, "Elle s'applique donc au personnel des sociétés concessionnaires ou à celui des organismes privés chargés de la gestion d'un service public. C'est dire que la délimitation de l'ample domaine d'application de ces règles se heurte à toutes les difficultés que suscite la définition (matérielle) du service public. Son application dans les entreprises nationalisées bouleverse les frontières traditionnelles. Il conviendrait sans doute de lier beacoup plus fortement le benefice d'un statut public d'emploi et les restrictions du droit de grève justifiés par la nécessaire continuité du service public. (PÉLISSIER, Jean; SUPIOT, Alain; JEAMMAUD, Antoine. Droit du travail. 21 ed. Paris: DAlloz, 2002, p. 1227).

${ }^{133}$ Cabe aqui transcrever novamente os ensinamentos de Jean Pélissier, Alain Supiot e Antoine Jeammaud, segundo quem: "Pour le secteur privé, le legislateur s'est abstenu d'intervenir. A-t-il eu tort ou raison? Il avait en tous cas ses raisons, et il n'existe pas de loi réglementant - c'est-à-dire restreignant, soummettant à des conditions de fond et à des procédures - l'exercice du droit de greve. Les régles qui gouvernent son exercice sont donc dégagées par les juges. Même la convention collective ne peut donc fixer des restrictions qui seraient opposables aux salariés exerçant leur droit constitutionnel. La réglementation ne peut venir que de la loi, pas des partenaires sociaux. En revanche le juge administratif decide qu'en l'absence de réglementation légale du droit de greve, il appartient aux chefs de service publics de fixer eux-mêmes, sous le controle du juge, les limitations à apporter au droit de grève en vue d'en éviter un usage abusif ou contraire aux necessites de l'ordre public ou aux besoins essentiels de la Nation". (PÉLISSIER, Jean; SUPIOT, Alain; JEAMMAUD, Antoine. Droit du travail. 21 ed. Paris: DAlloz, 2002, p. 1227). Bastante relevante é também a seguinte afirmação de Joseph FROSSARD (Les obstacles juridiques au déclenchement des greves. Droit social, n. 9-10, septembre-octobre 1988, p. 638): "Le problème de la réglementation du droit de grève est souvent posé; nous constatons pour l'heure que cette réglementation ne se pose pas uniquement en termes de devenir: elle existe sous la forma peut-être la moins acceptable parce qu'accidentelle: la réglementation prétorienne".

${ }_{134}$ Artigo 57. ${ }^{\circ}$ Direito à greve e proibição do lock-out. 1. É garantido o direito à greve. 2. Compete aos trabalhadores definir o âmbito de interesses a defender através da greve, não podendo a lei limitar esse âmbito. 3. A lei define as condições de prestação, durante a greve, de serviços necessários à segurança e manutenção de equipamentos e instalações, bem como de serviços mínimos indispensáveis para ocorrer à satisfação de necessidades sociais impreteríveis. 4. É proibido o lock-out. (Disponível em: <http://www.hri.org/docs/syntagma/artcl25.html\#A23>, acesso em 25/12/10).

${ }^{135}$ Article 23. 1. The State shall adopt due measures safeguarding the freedom to unionise and the unhindered exercise of related rights against any infringement thereon within the limits of the law. 2. Strike constitutes a right to be exercised by lawfully established trade unions in order to protect and 
afirma Gino Giuni, a qualificação do direito de greve como um direito constitucional apresenta diversas implicações. Primeiramente o consagra como um direito público de liberdade, qualificação que indica que o preceito interfere na relação entre Estado e cidadão, na medida em que não permite a elaboração de algum procedimento legislativo, administrativo ou jurisdicional que contraste com o direito de greve ${ }^{138}$. É preciso reconhecer, contudo, que o direito de greve também interfere nas relações intersubjetivas individuais privadas, na medida em que impede o empregador de praticar atos que impeçam o seu exercício ${ }^{139}$.

O reconhecimento da greve como um direito constitucional faz com que a participação de determinado trabalhador em um movimento desta natureza não possa sequer ser considerada inadimplemento contratual. É o que salienta Gino Giugni, ao aplaudir a jurisprudência italiana:

L'esercizio del diritto di sciopero produce la sospensione delle due obbligazioni fondamentali del rapporto di lavoro: il lavoratore há la facoltà di non prestare il lavoro e, di conseguenza, viene meno - in virtù del principio sinalagmático - l'obbligo del datore di corrispondere la retribuzione. Se lo sciopero non fosse riconosciuto com diritto, alla sospensione della prestazione conseguirebbe non solo la non corresponsione della retribuzione, ma anche una responsabilità di natura contrattuale, che esporrebe il

promote the financial and the general labour interests of working people. Strikes of any nature whatsoever are prohibited in the case of judicial functionaries and those serving in the security corps. The right to strike shall be subject to the specific limitations of the law regulating this right in the case of public servants and employees of local government agencies and of public law legal persons as well as in the case of the employees of all types of enterprises of a public nature or of public benefit, the operation of which is of vital importance in serving the basic needs of the society as a whole. These limitations may not be carried to the point of abolishing the right to strike or hindering the lawful exercise thereof. (disponível em <http://www.hri.org/docs/syntagma/artcl25.html\#A23>. Acesso em 25/12/2010)

${ }^{136}$ Artículo 28. 2. Se reconoce el derecho a la huelga de los trabajadores para la defensa de sus intereses. La ley que regule el ejercicio de este derecho establecerá las garantías precisas para asegurar el mantenimiento de los servicios esenciales de la comunidad. (Disponível em <http://constitucion.rediris.es/legis/1978/ce1978.html>. Acesso em 25/12/10).

137 Article 17. Any trade union or employer or association of employers shall be entitled to take strike or lock-out action or any similar measure unless otherwise provided by law or arising out of an agreement. (Disponível em http://www.servat.unibe.ch/icl/sw00000_.html Acesso em 25/12/10)

138 GIUNI, Gino. Diritto sindacale. Aggiornato da Lauralba Bellardi, Pietro Cursio e Mario Giovanni Garofalo. Bari: Cacucci Editore, 2010, pp. 235/236.

${ }^{139}$ Gino Giugni observa, em relação à legislação italiana, que "La rilevanza di questi effetti, negata in un primo tempo in base alla dogmática scissione tra diritto pubblico - cui appartiene il diritto costituzionale - e diritto privato, fu riconosciuta sotto l'impulso della dottrina e trovo conferma esplicita nella legislazione, quando l'art. 4 della legge n. 604/1966 cichiarò nullo licenziamento <<determinato dalla partecipazione ad attività sindacali > e, quindi, anche dalla partecipazione ad uno sciopero. Questa tutela venne ulteriormente ed esplicitamente estesa dalla 1. n. 300/1970 (Statuto dei lavoratori) nei confronti di ogni diritto di sciopero (art. 28)". (GIUNI, Gino. Diritto sindacale. Aggiornato da Lauralba Bellardi, Pietro Cursio e Mario Giovanni Garofalo. Bari: Cacucci Editore, 2010, pp. 235/236). 
laboratore a sanzioni disciplinari ed, eventualmente, al licenziamento per inadimpiemento ${ }^{140}$

Bernard Teyssié, ressalva, contudo, que o reconhecimento efetivo da greve como um direito, ao contrário do que se poderia imaginar, ainda é um fenômeno minoritário, raramente observado fora das fronteiras das economias ocidentais. Isto justificaria, por exemplo, o fato de a greve não ser incluída na lista de direitos sociais fundamentais da Declaração Universal de Direito do Homem, não ter sido analisada em Convenção própria da Organização Internacional do Trabalho ${ }^{141}$.

\subsection{NATUREZA DO DIREITO DE GREVE}

Quando se fala em estudar a natureza do direito de greve, duas abordagens são possíveis. A primeira delas seria buscando situá-lo entre três possibilidades: a) fato social; b) liberdade; c) direito.

Há quem sustente que a greve seria um fato social não passível de regulamentação jurídica, porque não há lei elaborada pelo Estado capaz de impedir a eclosão ou terminar uma greve contra a vontade dos trabalhadores. Amauri Mascaro Nascimento observa que se assim efetivamente fosse, a greve seria, por um lado, favorecida pela desregulamentação que afasta qualquer tipo de limitação. Teria, por outro lado e como decorrência da mesma circunstância, que lidar com a falta de respaldo jurídico capaz de impedir a ação arbitrária do Estado. Isso porque, em sua opinião, a norma jurídica é necessária como respaldo ao exercício do direito. Sem ela, o direito não encontrará suporte, não havendo que se falar em direito de greve. A manifestação coletiva não passaria, então, de uma ação física de reflexos confinados ao mundo da experiência ${ }^{142}$.

O mesmo autor também refuta a ideia de enquadrar a greve como uma liberdade inerente ao ser humano. Entende que se a ela fosse atribuída esse qualificativo, não haveria como incluir, na ordem jurídica, medidas destinadas à sua limitação, porquanto a liberdade consiste justamente na qualidade daquilo que não está sujeito à nenhum tipo de

\footnotetext{
${ }^{140}$ Idem

141 TEYSSIÉ, Bernard. Grève dans le secteur privé. Jurisclasseur Travail Traité, fasc. 70-10, 15 avril 2010.

${ }^{142}$ NASCIMENTO, Amauri Mascaro. Direito do trabalho na Constituição de 1988. $2^{\text {a }}$ edição. São Paulo: Saraiva, 1991, p.292.
} 
constrangimento. A greve não ficaria dependente de nenhuma lei e se justificaria por si mesma, como resultante da liberdade de trabalho ${ }^{143}$.

A teoria da greve como liberdade também afasta desde logo a possibilidade de reconhecimento do sindicato como titular do poder, uma vez que não seria razoável deslocar a titularidade da liberdade da pessoa individual para o sindicato e os direitos de personalidade não têm como titular uma pessoa jurídica. Somente a pessoa física.

A adoção desta teoria traria ainda o inconveniente de precisar definir se greve corresponderia a uma liberdade pública, privada ou a ambas. Considerada uma liberdade pública, a greve seria um fenômeno equacionado aos parâmetros da relação entre os cidadãos e o Estado. Justificar-se-ia, assim, greves contra o Estado fora da dimensão trabalhista, o que não parece a finalidade do instituto, pelo menos em uma acepção mais estrita da palavra. Considerada uma liberdade privada, possível seria cogitar de exercício intersubjetivo privado contra o empregador. Sendo liberdade pública e privada, estariam fundamentadas tanto as greves contra o Estado com as contra o empregador ${ }^{144}$.

Após esta breve digressão, o Professor Emérito da Universidade de São Paulo observa que as liberdades se expressam como garantias jurídicas, o que torna a sua relação com o conceito de direito fundamental bastante estreita, a menos que se sustente que o direito é fundado na ordenação jurídica positiva, enquanto a liberdade não, questão que levaria menos à verificação da natureza jurídica da greve e mais à sua fundamentação ${ }^{145}$.

Como se pode observar nos itens anteriores, a greve passou, ao longo da história, por diversas fases. Inicialmente foi considerada um ilícito, em um segundo momento foi tolerada e finalmente aceita como um direito. Mas, se ela hoje é aceita como um direito, de que espécie de direito se trata? Esta é um pergunta que até hoje causa inquietação na doutrina nos mais diversos países.

Para alguns, a greve seria um direito subjetivo potestativo na medida em que o trabalhador teria o poder de modificar com a sua vontade ou com o simples exercício do seu direito uma situação jurídica da qual é parte outro sujeito, o empregador, a quem não

\footnotetext{
${ }^{143}$ Ibidem.

${ }^{144}$ Ibidem, p. 293.

145 NASCIMENTO, Amauri Mascaro. Direito do trabalho na Constituição de 1988. 2a edição. São Paulo: Saraiva, 1991, p. 293.
} 
restaria alternativa que não a submissão à manifestação. Gino Giugni afirma que esta teoria, contudo, não seria compatível com a idéia de que o direito de greve pode voltar-se não apenas para a tutela de interesses profissionais conexos com o contrato de trabalho, mas também para tutela de interesses político-econômicos ${ }^{146}$. Luisa Galantino adota posição diversa ao asseverar que o reconhecimento do direito de greve como um direito potestativo não é incompatível com a ampliação dos objetivos dos movimentos paredistas para admiti-los também como forma de luta direta contra governo e parlamento para conseguir ou evitar políticas contrárias aos interesses dos trabalhadores. Para ela, o direito de greve constituir-se-ia sempre em direito potestativo quando as reivindicações fossem dirigidas ao empregador, apresentando natureza diversa quando tivessem outra finalidade $^{147}$.

Para Gino Giugni a qualificação do exercício do direito de greve como um negócio jurídico tampouco se mostra convincente. Primeiramente porque no comportamento do trabalhador grevista não se observa intento negocial. Este intento negocial poderia, quando muito, ser individualizado na proclamação da greve pela organização sindical. Referido autor, contudo, entende que a titularidade do direito de greve seria do trabalhador e não do sindicato, o que afastaria a aceitabilidade desta teoria ${ }^{148}$.

A teoria de que a greve seria um direito da personalidade, um direito de liberdade ou direito político, é, sem dúvida, mais idônea para descrever a ampliação do conceito de greve. Sob esta perspectiva, a greve se apresentaria como um meio de desenvolvimento dos trabalhadores e de promoção de sua participação na vida política, econômica e social do país. Quando analisada enquanto um instrumento para obtenção de um bem necessário para o desenvolvimento da pessoa, a greve seria um direito da personalidade. Sempre que vista como uma garantia de não interferência dos poderes públicos ou privados em seu exercício, a greve seria um direito de liberdade.

Sob a segunda possível forma de classificação, cabe definir se a greve teria natureza de meio de ação sindical, se seria, ela própria, um conflito, ou se seria um meio de solução de conflito.

\footnotetext{
${ }^{146}$ Neste sentido é a opinião de Gino Giugni. (GIUGNI, Gino. Diritto sindacale. Aggiornato da Lauralba Bellardi, Pietro Cursio e Mario Giovanni Garofalo. Bari: Cacucci Editore, 2010, p. 239).

${ }^{147}$ GALANTINO, Luisa. Diritto sindacale. Torino: Giappichelli Editori, 2009, p. 205.

${ }^{148}$ Op cit, p. 240.
} 
Amauri Mascaro Nascimento, responsável pelas ideias que refutaram o enquadramento da greve como fato social e como liberdade, conclui, na linha do que já fora sustentado anteriormente neste trabalho, que a greve é forma de autodefesa conferida pela ordem jurídica. Através dela, faculta-se aos trabalhadores o uso de uma ação direta, por meio da qual possam responder à alteração das condições objetivas existentes, prejudiciais aos seus interesses, salariais ou não, e forçar a modificação do contrato de trabalho, impondo a sua vontade ${ }^{149}$. Segundo seu entendimento, a greve seria enquadrável tanto como meio de ação sindical, quanto como meio de solução de conflito.

Jorge Luiz Souto Maior, por sua vez, destaca que "a greve não é um modo de solução de conflitos e sim uma forma de expressão do próprio conflito. Trata-se de um instrumento de pressão, legitimamente utilizado pelos empregados para a defesa de seus interesses" ${ }^{150}$. Seus ensinamentos, embora apresentem ênfase na figura da greve como o próprio conflito, findam por enquadrar a greve também como um meio de ação à disposição dos empregados.

Mais adequada nos parece a solução proposta por Oscar Ermida Uriarte. Em sua opinião, a greve teria tríplice natureza. Ela é ou pode ser um meio de ação sindical ou gremial, um conflito coletivo de trabalho ou uma forma de solucionar o conflito ${ }^{151}$, neste caso nitidamente uma forma de autotutela.

Antes do conflito - fazendo a ressalta de que o conceito de antes, durante e depois é abstrato, porque muitas vezes tudo pode ocorrer ao mesmo tempo - Ermida Uriarte salienta que a greve é um meio de ação do sindicato ou do grêmio, da coletividade de trabalhadores. Um entre tantos meios de ação que se lhes põe à disposição, como um desfile, uma manifestação, uma petição apresentada perante uma empresa ou ante as autoridades públicas. Neste momento ela é o instrumento através do qual pode atuar a coletividade de trabalhadores e o sindicato ${ }^{152}$.

\footnotetext{
${ }^{149}$ NASCIMENTO, Amauri Mascaro. Direito do trabalho na Constituição de 1988. $2^{\text {a }}$ edição. São Paulo: Saraiva, 1991, p. 293.

${ }^{150}$ MAIOR, Jorge Luiz Souto. O direito de exercer o direito de greve. In: THOMÉ, Candy Florêncio e SCHWARZ, Rodrigo Garcia. Direito coletivo do trabalho: curso de revisão e atualização. Rio de Janeiro: Elsevier, 2010, p. 256.

151 "En realidad la huelga es - o puede ser - cualquiera de esas tres cosas y aún las tres a la vez; un médio de acción sindical o gremial, un conflicto colectivo de trabajo, y una forma de solucionar el conflicto". (ERMIDA URIARTE, Oscar. Apuntes sobre la huelga. $2^{\mathrm{a}}$ ed. Fundación de cultura universitária. Montevideo: 1996., p. 16).

152 Ibidem, p. 17.
} 
Uma vez desencadeada, a greve se torna um conflito, o típico conflito de trabalho. "El más típico de todos, y el más grave; puede haber muchos otros conflictos, pero cuando hablamos de los conflictos del trabajo, casi siempre estamos hablando de la huelga; Ella es, sin Duda, un conflicto colectivo, el principal de los conflictos colectivos" ${ }^{\prime 153}$.

É nesse momento que surge o questionamento acerca da natureza da greve como o conflito em si mesmo ou como forma de solução do conflito. Os que sustentam que a greve não é um conflito, mas um meio de solucioná-lo, dizem que ao se desencadear uma greve, a controvérsia já se havia criado. Ermida Uriarte, contudo, considera certa a afirmação dos que creem que a greve é, a um só tempo, o conflito de trabalho e uma das formas de solucioná-lo. Seria, portanto, um conflito que apresenta a pretensão de ser também o meio de solução do próprio conflito. Seria, diz citando Mario Pasco, uma maneira de exacerbar o conflito para solucioná-lo. Em outra palavra, seria "una forma unilateral de solucionar el conflicto que implica imponer la própria solución a la contraparte". Se não tiver êxito o conflito se solucionará de outra maneira, seja porque a greve se perde e se impõe a vontade da contraparte, seja porque se obtém algum tipo de acordo por meio de convenção coletiva, mediação, conciliação, arbitragem, etc ${ }^{154}$.

Em suma, sob o ponto de vista do trabalhador singularmente considerado, a greve seria um direito da personalidade, um direito de liberdade ou direito político, conforme seja analisada sob a perspectiva de ser um instrumento para obtenção de um bem necessário para o desenvolvimento da pessoa; como uma garantia de não interferência dos poderes públicos ou privados em seu exercício; ou como um meio de desenvolvimento dos trabalhadores e de promoção de sua participação na vida política, econômica e social do país, respectivamente.

Sob o ponto de vista da coletividade, a greve teria a trivalência de ser um meio de ação sindical, o principal dos conflitos coletivos de trabalho e, ao mesmo tempo, um dos meios de solução do conflito coletivo ${ }^{155}$. Esta discussão, ao contrário do que a princípio possa parecer, não está adstrita ao campo da discussão doutrinária. Ela apresenta importante efeito de ordem prática, relacionado com o escopo do presente estudo. Em

\footnotetext{
153 Ibidem.

${ }_{155}^{154}$ Ibidem, p. 16/17

155 ERMIDA URIARTE, Oscar. Apuntes sobre la huelga. $2^{\mathrm{a}}$ ed. Fundación de cultura universitária. Montevideo: 1996, p. 17.
} 
sendo a greve reconhecida apenas como um conflito, a intervenção judiciária para solucionar este conflito se justifica com maior força e amplitudo, em particular em um país em que a Constituição afirma categoricamente que nenhuma lesão ou ameaça de lesão à direito poderá ser excluída da apreciação do Judiciário (art. 5, XXXV). Sendo ela simultaneamente um conflito e um meio de solução deste conflito, ou, como salientado, uma maneira de exarcerbar o conflito para solucioná-lo, uma intervenção precipitada ou inadequada do judiciário findará por tornar completamente ineficaz este importante instrumento democrático.

\subsection{TITULARIDADE DO DIREITO DE GREVE}

O primeiro questionamento a se definir acerca do direito de greve é se o seu titular é o sindicato ou se são os trabalhadores. Esta definição é relevante, por exemplo, para se reconhecer se o direito em questão poderia, na ausência de organização sindical, ser exercido por grupos de trabalhadores organizados de outra forma ou sob outra justificativa. Esta discussão teve particular relevância no Chile, onde o direito de greve foi durante muito tempo tratado no Codigo de 1931 sob o título "De la intervención de los sindicatos em los conflictos de trabajo", o que poderia ser interpretado como um indicativo de que somente os trabalhadores organizados em sindicatos poderiam exercer este direito. A jurisprudência dos tribunais e dos organismos administrativos, entretanto, consolidou-se no sentido de que essas disposições eram aplicáveis aos trabalhadores que, sem estar organizados sindicalmente, planejavam um conflito coletivo, o que naturalmente poderia desembocar em uma greve já que não havia probição expressa a este respeito ${ }^{156}$. Esta interpretação flexível da legislação atinente à greve se mostra bastante razoável e vai de encontro às ideias defendidas neste trabalho.

$\mathrm{O}$ art. 57 da Constituição uruguaia dispõe que "Declárase que la huelga es un derecho gremial. Sobre esta base se reglamentará su ejercicio y efectividad”. Ao analisá-lo, Oscar Ermida Uriarte pondera que o uso da expressão "derecho gremial” denota que o titular do exercício do direito de greve é a coletividade de trabalhadores, o grêmio, entendido como o grupo profissional inorgânico. A expressão "direito gremial”, seria, em sua abalizada opinião, mais ampla do que direito sindical. Havendo oposição entre uma

\footnotetext{
${ }^{156}$ ARTEAGA, William Thayer e FUENZALIDA, Patricio Novoa. Manual de derecho del trabalho, tomo I, Generalidades, Derecho Colectivo del trabajo. 5a edición. Santiago: 2007, p. 176.
} 
declaração do sindicato e a atitude ou declaração de conjunto dos trabalhadores, o texto constitucional poderia, outrossim, fazer prevalecer a opinião ou a atitude do conjunto dos trabalhadores, da coletividade de trabalhadores. O texto constitucional uruguaio daria ainda guarida à chamada greve selvagem, assim entendida a exercida pelo conjunto de trabalhadores contra uma decisão sindical de não fazer greve, diferentemente do que ocorre nos regimes que consideram a greve um direito do sindicato ${ }^{157}$.

Na doutrina e jurisprudência italianas, a opinião atualmente dominante é no sentido de que os titulares do direito de greve são os trabalhadores singularmente considerados e não o sindicato enquanto coletividade ${ }^{158}$. Gino Giugni observa, a este respeito, que se o titular do direito de greve fosse o sindicato que a proclama, não haveria como se justificar o fato de o seu exercício suspender também a obrigação de trabalhar dos trabalhadores não $\operatorname{associados}^{159}$. A greve seria, segundo os italianos, um direito individual de exercício coletivo, ou, como afirma Luisa Galantino, "atto collettivo nella deliberazione, ma non necessariamente nell'attuazione". Poder-se-ia, a partir deste entendimento, afirmar que a ausência de um único trabalhador ao serviço poderia ser considerada greve, quando esta tiver sido proclamada assim por um grupo de trabalhadores e se destinar a tutela de um interesse coletivo ${ }^{160}$. Pode-se também concluir, com apoio no magistério de Homero Batista Mateus da Silva, que "sem que o grupo de trabalhadores tenha deliberado deflagrar

157 ERMIDA URIARTE, Oscar. Apuntes sobre la huelga. $2^{\mathrm{a}}$ ed. Fundación de cultura universitária. Montevideo: 1996, p. 21.

${ }^{158}$ GALANTINO, Luisa. Diritto sindacale. Torino: Giappichelli Editori, 2009, p. 207; GIUNI, Gino. Diritto sindacale. Aggiornato da Lauralba Bellardi, Pietro Cursio e Mario Giovanni Garofalo. Bari: Cacucci Editore, 2010, p. 237. Santoro-Passarelli, contudo, ainda questiona esta afirmação. Para ele "La distinzione fra titolarità individuale ed esercizio collettivo solleva qualche perplessità perché, a bem vedere, lo sciopero può essere attuato solo per la difesa di un interesse collettivo. E, como il soggetto colletivo, parimenti dovrebbe essere il soggetto colletivo a valutare l'opportunità di esercitare il diritto di sciopero, ferma ovviamente la liberta dei singoli lavoratori di aderirvi o meno. In altri termini, alla formula $<<$ titolarità individuale ed esercizio collettivo dello sciopero >> potrebbe contraporsi la formula <<titolarità collettiva ed esercizio individuale dello sciopero $>>$ (SANTORO-PASSARELLI, Giuseppe. Diritto sindacale. Bari: Editori Laterza, 2009, p. 146).

${ }^{159}$ GIUNI, Gino. Diritto sindacale. Aggiornato da Lauralba Bellardi, Pietro Cursio e Mario Giovanni Garofalo. Bari: Cacucci Editore, 2010, p. 237. Em sentido idêntico, mas tratando do ordenamento jurídico francês, Jean Pélissier, Alain Supiot e Antoine Jeammaud, destacam que: “La spontaneité de la greve n'est pas rare. Dans toutes les entreprises privées qui ne gèrent pas un service public, les salariés peuvent arrêter le travail et se mettre em greve, em l'absence de toute iniciative syndicale: <<um arrèt de travail ne perd pas le caractere de grève ilicite du fai qu'il n'a pas été déclenché à l'appel d'um syndicat $>>$. C'est seulement dans les entreprises gérant du service public que l'ordre de grève doit nécessairement meaner d'une organization syndicale. (PÉLISSIER, Jean; SUPIOT, Alain e JEAMMAUD, Antointe. Droti du travail. 21 ed. Paris: DAlloz, 2002, p. 1232).

${ }^{160}$ GALANTINO, Luisa. Diritto sindacale. Torino: Giappichelli Editori, 2009, p. 207. 
o movimento grevista, a paralisação dos trabalhos por parte de um único operário ou por pequeno grupo de empregados não receberá o tratamento de greve" ${ }^{161}$.

Bernand Teyssié faz referência a um interessante precedente segundo o qual depois de deflagrada greve com participação da maior parte dos trabalhadores, se a maioria dentre eles se pronunciar a favor da retomada do trabalho, aqueles que permanecerem se recusando a retornar à atividade permanecerão cobertos pelo direito de greve. O fundamento seria de que se trata de "un droit individuel non un privilège syndical qu'une décision prise au sein d'une organisation déterminée, puis favorablement accueillit par une majorité de salariés, interdirait d'exercer" ${ }^{\prime 162}$.

Outro argumento utilizado para fundamentar a tese da titularidade individual do direito de greve é o de que ela poderia ser praticada até mesmo por grupos de trabalhadores não organizados em sindicato ${ }^{163}$. Sob este aspecto, o Brasil claramente refuta a tese de titularidade do direito de greve pelo sindicato ao estatuir, no artigo $4^{\circ}$, $\S 2^{\circ}$ da Lei 7.783/89, que "na falta de entidade sindical, a assembléia geral dos trabalhadores interessados deliberará para os fins previstos no caput, constituindo comissão de negociação". Octávio Bueno Magano e Estêvão Mallet consideram esse dispositivo inconstitucional por não se harmonizarem com o artigo $8^{\circ}$, VI da Carta Magna. Asseveram, que "se a participação do sindicato é necessária em todo o processo de negociação, é óbvio não poder operar-se a sua substituição por comissão negociadora" ${ }^{\text {164 }}$.

Além de inconstitucional, referidos professores consideram o preceito anódino porque, no sistema sindical brasileiro, é impossível configurar-se a falta de entidade sindical. Se na localidade em que eclodir a greve não existir sindicato, deverão ser os grevistas representados por federação e, na falta desta, por confederação ${ }^{165}$.

Ari Possidônio Beltran não considera a aludida comissão inconstitucional e a enquadra na definição de coalisão por considerar que ela se forma para enfrentar uma

\footnotetext{
${ }^{161}$ SILVA, Homero Mateus Batista da. Curso de direito do trabalho aplicado, vol. 7: direito coletivo do trabalho. Rio de Janeiro: Elsevier, 2010, p. 257.

${ }^{162}$ V. Cass. Crim., 27 nov. 1973: Dr. Ouvrier 1974, p. 178 apud TEYSSIÉ, Bernard. Grève dans le secteur privé. Jurisclasseur Travail Traité, fasc. 70-10, 15 avril 2010.

${ }_{163}$ GIUGNI, Gino. Diritto sindacale. Aggiornato da Lauralba Bellardi, Pietro Cursio e Mario Giovanni Garofalo. Bari: Cacucci Editore, 2010, p. 237.

${ }^{164}$ MAGANO, Octávio Bueno; MALLET, Estêvão. $O$ direito do trabalho na constituição. Rio de Janeiro: Forense, 1993, p. 313.

${ }^{165}$ Idem, p. 314.
} 
situação determinada, desaparecendo tão logo seja superado o impasse identificado ${ }^{166}$. Durante a sua vigência, caber-lhe-á representar os trabalhadores nas tratativas extrajudiciais, bem como em eventual necessidade de recurso à Justiça do Trabalho, nos termos do que preceitua o art. $5^{\circ}$ da Lei 7.783/89.

É preciso, contudo, reconhecer que a opção de determinado país por reservar exclusivamente às organizações sindicais o direito de declarar greve não vem sendo considerado pelo Comitê de Peritos da OIT, sobre o qual se discorrerá mais a seguir, incompatível com as normas estabelecidas pela Convenção 87 da referida Organização Internacional ${ }^{167}$. O mesmo organismo não admite, no entanto, a imposição de proibição de declarar a greve às federações e confederações, por considerá-la incompatível com a Convenção n. 87 da $\operatorname{OIT}^{168}$.

Contrastando os ordenamentos jurídicos de Chile e Itália tem-se uma diferença substancial no que diz respeito ao quórum necessário para a deflagração da greve. Enquanto no Chile o quórum necessário para fazer efetiva a greve é de maioria absoluta dos pelo menos $2 / 3$ dos trabalhadores em conflito ${ }^{169}$, na Itália o legislador não quantifica $a$ priori o número mínimo de trabalhadores que devem proclamar a greve, trata-se de uma questão de fato que deve ser solucionada casuisticamente, não exigindo a legislação nenhum ato formal de proclamação da greve pela organização sindical ${ }^{170}$.

\footnotetext{
${ }^{166}$ Segundo Ari Possidônio Beltran, as coalizões seriam de sujeitos coletivos, assim como os sindicatos, os conselhos de empresa, os delegados de pessoal, as assembléias de pessoal, as seções e delegados sindicais da empresa, as associações patronais e o empresário individual que teriam por característica o fato de serem agrupamentos esporádicos - seja de trabalhadores, seja de empregadores. Com sua aparição esporádica, elas se formam para enfrentar uma situação determinada, que, sendo superada, da mesma forma desaparecem, seja após a realização de uma greve, seja após a negociação de um acordo coletivo. (BELTRAN, Ari Possidônio. A autotutela nas relações do trabalho. São Paulo: LTr, 1996, pp. 139/140)

${ }^{167}$ Precedente 524 da 5 a edição da Recopilación de decisiones y princípios del Comité de Libertad Sindical del Consejo de Administración de la OIT que assim dispõe: "No parece que el hecho de reservar exclusivamente a las organizaciones sindicales el derecho de declarar una huelga sea incompatible con las normas establecidas en el Convenio núm. 87. Aunque es preciso, sin embargo, que los trabajadores, y en particular los dirigentes de los mismos en las empresas, estén protegidos contra eventuales actos de discriminación a consecuencia de una huelga realizada en dichas condiciones, y que puedan constituir sindicatos sin ser víctimas de prácticas antisindicales". (Véase Recopilación de 1996, párrafo 477; $334 .^{\circ}$ informe, caso núm. 2258, párrafo 454 y 336. informe, caso núm. 2153, párrafo 173.)

${ }^{168}$ Precedente 525 da $5^{\text {a }}$ edição da Recopilación de decisiones y princípios del Comité de Libertad Sindical del Consejo de Administración de la OIT que assim dispõe:. La prohibición impuesta a las federaciones y confederaciones de declarar la huelga no es compatible con el Convenio núm. 87. (Véase Recopilación de 1996, párrafo 478 y 306. ${ }^{\circ}$ informe, caso núm. 1884, párrafo 686.)

${ }^{169}$ ARTEAGA, William Thayer e FUENZALIDA, Patricio Novoa. Manual de derecho del trabalho, tomo I, Generalidades, Derecho Colectivo del trabajo. 5a edición. Santiago: 2007, p. 176.

${ }^{170}$ Cf. Luisa Galantino: "il legislatore non quantifica a priori il numero mínimo di lavoratori che devono proclamare lo sciopero. É dunque uma questione di fatto stablire se sussista uma colletività di lavoratori sufficientemente rappresentativa degli interessi di gruppo difesi, non essendo necessária la sussistenza di um
} 
O Brasil adota uma solução diversa da adotada nos referidos países. A nossa legislação estatui, no artigo $4^{\circ}, \S 1^{\circ}$ da Lei 7.783/89, que "o estatuto da entidade sindical deverá prever as formalidades de convocação e o quórum para a deliberação, tanto da deflagração quanto da cessação da greve”. Octávio Bueno Magano e Estêvão Mallet vêem na exigência de aprovação de assembleias gerais de associados um indicativo de que o legislador concebeu a greve como direito sindical e não de trabalhadores desinformados, desejando com isso evitar as chamadas greves selvagens. Afirmam ainda que, diante do disposto no artigo $7^{\circ}$, VI, da Constituição, essa diretriz era efetivamente inevitável, já que a participação dos sindicatos é obrigatória, por mandamento constitucional, nas negociações coletivas de trabalho e, pois, também durante o período de greve, já que a negociação, lato sensu, se define como todo processo tendente à solução de disputas ${ }^{171}$.

Ao permitir que o quórum para deflagração da greve seja determinado no estatuto de cada sindicato, a lei de greve distoa de preceitos do texto consolidado que até hoje indicam o quórum mínimo para aprovação de determinado movimento ${ }^{172}$. A solução adotada pela Lei de Greve brasileira mostra-se muito mais consentânea com os princípios de liberdade sindical do que o texto consolidado. Não há falar em liberdade efetiva em um regime em que a legislação imperativa estatal impõe a presença de um determinado número de pessoas para deflagração da greve. É preciso, entretanto, reconhecer a necessidade de ponderação e parcimônia na fixação do quórum estatutário. Norma que reduza esse número a um mínimo insignificante, insuficiente para representar a vontade do grupo interessado, é flagrantemente abusiva e, portanto, deve ser reputada nula. Quando verificada esta hipótese, a melhor solução para o impasse criado com a anulação da norma é aquela apregoada por Julpiano Chaves Cortez também para as hipóteses de ausência de

atto formale di proclamazione dello sciopero da parte di un'organizzazione sindacale" (GALANTINO, Luisa. Diritto sindacale. Torino: Giappichelli Editori, 2009, p. 207).

${ }^{171}$ MAGANO, Octávio Bueno; MALLET, Estêvão. O direito do trabalho na constituição. Rio de Janeiro: Forense, 1993, p. 313.

${ }^{172}$ Art. 612 da CLT. Os sindicatos só poderão celebrar Convenções ou Acordos Coletivos de Trabalho, por deliberação de Assembléia Geral especialmente convocada para este fim, consoante o disposto nos respectivos Estatutos, dependendo a validade da mesma do comparecimento e votação, em primeira convocação, de $2 / 3$ (dois terços) dos associados da entidade, se se tratar de Convenção, e dos interessados, no caso de Acordo, e, em seguida, de 1/3 (um terço) dos mesmos.

Parágrafo único. O quorum de comparecimento e votação será de 1/8 (um oitavo) dos associados em segunda convocação, nas entidades sindicais que tenham mais de 5.000 (cinco mil associados).

Art. 859 da CLT. A representação dos sindicatos para instauração da instância fica subordinada à aprovação de assembléia, da qual participem os associados interessados na solução do dissídio coletivo, em primeira convocação, por maioria de $2 / 3$ (dois terços) dos mesmos, ou, em segunda convocação, por 2/3 (dois terços) dos presentes. 
norma estatutária, qual seja a aplicação supletiva do quórum previsto no artigo 859 da $\mathrm{CLT}^{173}$.

Cabe ainda uma última reflexão relacionada com a titularidade do direito de greve. Sendo ela efetivamente um direito individual de exercício coletivo, poderia a greve ser considerada abusiva em razão de excessos praticados por um ou alguns dos manifestantes? Duas questões devem ser consideradas quanto a este ponto. A primeira é a responsabilidade individual dos grevistas que se excederem em suas manifestações. Esta é indiscutível. A suspensão do contrato de trabalho pelo movimento paredista não interfere no dever de respeito recíproco que deve existir entre as partes. Desta feita, empregado que agredir fisicamente o empregador poderá, naturalmente, ser dispensado por justa causa. $\mathrm{O}$ empregado que danificar patrimônio da empresa e for identificado poderá ter o valor do dano provocado dolosamente descontado de sua remuneração na forma do artigo 462, $\S 1^{\circ}$ da Consolidação das Leis do Trabalho ${ }^{174}$.

Outra questão é a da análise acerca do desvirtuamento do movimento. Ora, em se tratando de uma ação coletiva, que pressupõe a união de vários titulares do direito de greve para que ela seja reputada válida, o excesso praticado por alguns dos manifestantes não contamina todo o movimento. Exemplificativamente, se em um movimento pacífico um único manifestante se exalta e, sem o aval do chamado comando de greve e sem a concordância dos demais manifestantes, agride outrem ou destrói patrimônio da empresa, a greve não perderá sua natureza e não deverá, por si só, ser considerada abusiva. Diversa será a solução quando a violência for coletiva, praticada pela maioria dos manifestantes e com a concordância, pelo menos tácita da direção sindical.

Admitir o contrário implicaria em possibilitar a punição de um trabalhador por haver participado de uma greve predominantemente pacífica, mas na qual um ou alguns poucos dos manifestantes se excederam e praticaram atos de violência. Há precedentes que, com base na finalidade do movimento grevista e sustentando-se na preocupação em não invalidar o exercício constitucional do direito à greve, concluem pela impossibilidade

\footnotetext{
${ }^{173}$ CORTEZ, Julpiano Chaves. A lei de greve. São Paulo: LTr, 2010, p. 53.

174 Art. 462 - Ao empregador é vedado efetuar qualquer desconto nos salários do empregado, salvo quando este resultar de adiantamentos, de dispositvos de lei ou de contrato coletivo.

$\S 1^{\circ}$ - Em caso de dano causado pelo empregado, o desconto será lícito, desde de que esta possibilidade tenha sido acordada ou na ocorrência de dolo do empregado.
} 
de se sujeitar um trabalhado a sanções disciplinares por participar de um movimento legítimo para a maioria ${ }^{175}$.

Corroborando esta conclusão, Bernard Teyssié, novamente com base em precedente da jurisprudência francesa, assevera que a atitude dos trabalhadores durante a greve deve ser apreciada sobre o domínio das relações individuais de trabalho, em referência à obrigação geral de boa fé ${ }^{176}$.

Outra questão de relevo acerca da titularidade do direito de greve é definir se ele seria assegurado apenas aos trabalhadores subordinados ou a todos os trabalhadores, independentemente da natureza do contrato firmado. Gino Giugni destaca, sob este aspecto, que se o direito de greve é reconhecido pela Constituição como instrumento para realizar o objetivo do artigo $3^{\circ}$, co. 2 da Constituição de seu país, o que conta não é a possibilidade formal de se enquadrar a prestação de serviço na hipótese do artigo 2.094 do Codice Civile, mas a situação de subproteção social do prestador. Observa inclusive que esta interpretação estensiva encontrou respaldo na Corte Costituzionale que, na decisão 222, proclamada em 17.7.1975, declarou a "l'illegittimità della norma incriminatrice della serrata posta in essere dagli esercenti di piccole industrie e comerce privi di lavoratori alle proprie dipendenze (art. 506 c.p) per contraposto con l'art. 40 Cost" ${ }^{177}$. Na ocasião consignou-se ser errado qualificar serrata - como no código penal italiano - "la protesta di questi imprenditori, perchè si tratta di un comportamento che non influisce su alcun rapporto di lavoro: svolgendo la loro attività di impresa solo con il lavoro próprio, esse sono qualificabili come datori di lavoro" ${ }^{178}$.

\footnotetext{
175 Sanções disciplinares aplicadas ao grevista. Limites. O movimento grevista visa primordialmente à manutenção da relação de emprego, lutando para o aprimoramento das condições de trabalho. Portanto, é preciso cautela no exame dessa matéria para não se invalidar o exercício constitucional do direito à greve, por entender que, participando de um movimento legítimo para a maioria, pratica o obreiro um ato capaz de lhe gerar sanções disciplinares. Logo não podemos visualizar na greve o aspecto individual, a não ser pelo comportamento distinto de cada empregado, pois ela é um fato coletivo. Além disso, há de serem observados os limites traçados pelo ordenamento jurídico (art. $9^{\circ}$, $\S \S 1^{\circ}$ e $2^{\circ}$, da CF/88 e Lei n. 7.783/89) (TRT $3^{a}$ Região, $7^{\mathrm{a}}$ Turma, RO 00066-2008-096-03-00-2 - Rela. Juíza Convocada Ana Maria Amorim Rebouças - DJMG 14.8.08)

${ }^{176}$ L'attitude des salairé doit, en consequence, être appréciée sur le terrain des relations individuelles de travail par reference à l'obligation générale de bonne foi, conformément à l'article 1134 du Code civil. Ils sont exposés au prononcé de sanctions disciplinaires dans les conditions de droit commum (Cass. soc., 5 mars 1953, préc. - Cass. soc., 6 janv. 1972, préc.). (TEYSSIÉ, Bernard. Grève dans le secteur privé. Jurisclasseur Travail Traité, fasc. 70-10, 15 avril 2010).

${ }^{177}$ GIUGNI, Gino. Diritto sindacale. Aggiornato da Lauralba Bellardi, Pietro Cursio e Mario Giovanni Garofalo. Bari: Cacucci Editore, 2010, p. 237.

178 Ibidem.
} 
A Corte di cassazione, por sua vez, na decisão n. 3.278. proferida em 29.6.78, reconheceu a titularidade do direito de greve dos trabalhadores autônomos em condição de parassubordinação. Neste precedente, os trabalhadores em questão eram médicos que pretendiam, com a sua abstenção de trabalhar, constranger o Serviço Sanitário Nacional a conceder-lhes condições mais favoráveis na Convenção que regulava a relação recíproca.

Justificando a sua interpretação extensiva, Gino Giugni destaca que a greve é historicamente um instrumento de luta de grupos sociais subalternos que, com isso, buscam reequilibrar o seu deficit de força social. Por conseguinte, quando a Constituição Italiana os fez sujeito de um direito tinha, evidentemente essa realidade histórica ${ }^{179}$.

A mesma razão histórica justifica uma interpretação estensiva do artigo $9^{\circ}$ da Constituição brasileira, para reconhecer que o direito nele consagrado alcança a todos os trabalhadores, ainda que não ligados ao empregador por um vínculo de emprego. Como salientou Gentil Mendonça, em obra publicada em 1978, mas de manifesta atualidade, em diversas passagens, nenhuma época exige maior poder de interpretação do direito do que esta. Como ele bem observou, o quadro científico da sociedade modificou-se de tal maneira que se tornou absolutamente impossível ao intérprete verdadeiro sentir e projetar o significado das leis, da jurisprudência e do justo, sem ter um embasamento filosófico, sociológico, histórico e jurídico, à altura de suas responsabilidades, atendendo à exigência do momento vivido ${ }^{180}$.

É certo que o artigo $2^{\circ}$ da Lei $7.783 / 89$ dispõe que "para os fins desta Lei, considera-se legítimo exercício do direito de greve a suspensão coletiva, temporária e pacífica, total ou parcial, de prestação pessoal de serviços a empregador", fazendo uso, portanto, de uma expressão que evidencia que no Brasil a legislação só considera greve as suspensões relativas a reivindicações de trabalhadores ligados por contrato de trabalho a empregadores. A sua literalidade, contudo, não pode ser considerado um óbice ao reconhecimento de que o mecanismo de autotutela trabalhista é extensível a outros trabalhadores e direcionável ao governo.

Dentro desta perspectiva, a paralisação realizada por quase 24 mil médicos residentes do Brasil, em agosto de 2010, em busca de reajuste de 38,7\% na bolsa-auxílio,

\footnotetext{
${ }^{179}$ Ibidem.

${ }^{180}$ MENDONÇA, Gentil. A interpretação no direito do trabalho. São Paulo: LTr, 1978, p. 102;
} 
congelada desde 2006 em R $\$ 1.916,45^{181}$, não poderia ser considerada greve por que os médicos residentes, cuja atividade está disciplinada na Lei 6.932/81, não são empregados, mas são trabalhadores em sentido amplo.

Aplicar-se-á aos trabalhadores não tutelados pela lei 7.783/89 a lógica aplicada aos servidores públicos grevistas antes do julgamento conjunto dos mandados de injunção 670, 708 e 712. Evidenciando esta conclusão há o fato de a própria constituição haver excluído da incidência da Lei 7.783/89, os servidores públicos, sem que isso tivesse constituído óbice para as mesmas. Ainda em 1993, Octávio Bueno Magano e Estêvão Mallet já enfatizavam que enquanto não fosse editada a lei complementar à qual faz referência o texto constitucional, os servidores poderão exercer o direito de greve nos termos dos demais trabalhadores, "porque todos os preceitos constitucionais são dotados de eficácia" ${ }^{182}$. Eles sustentavam já na primeira metade do ano 1993 que para não haver arbítrio na determinação dos limites do seu exercício, analogicamente, estes haverão de ser iguais aos estabelecidos para os demais trabalhadores, com a ressalva de que lei complementar regulamentadora do mesmo preceito poderá restringi-los ${ }^{183}$.

A tese por último referida acabou consagrada pelo Supremo Tribunal Federal no julgamento conjunto dos mandados de injunção 670,708 e $712^{184}$.

${ }^{181}$ Notícia disponível em <http://www.jornalpequeno.com.br/2010/8/18/medicos-residentes-paralisam-parapedir-reajuste-na-bolsa-e-valorizacao-128500.htm>. Acesso em 29 de dezembro de 2010.

${ }_{182}$ MAGANO, Octávio Bueno; MALLET, Estêvão. O direito do trabalho na constituição. Rio de Janeiro: Forense, 1993, p. 314.

${ }^{183}$ Ibidem, p. 314.

184 EMENTA: MANDADO DE INJUNÇÃO. ART. 5', LXXI DA CONSTITUIÇÃO DO BRASIL. CONCESSÃO DE EFETIVIDADE À NORMA VEICULADA PELO ARTIGO 37, INCISO VII, DA CONSTITUIÇÃO DO BRASIL. LEGITIMIDADE ATIVA DE ENTIDADE SINDICAL. GREVE DOS TRABALHADORES EM GERAL [ART. $9^{\circ}$ DA CONSTITUIÇÃO DO BRASIL]. APLICAÇÃO DA LEI FEDERAL N. 7.783/89 À GREVE NO SERVIÇO PÚBLICO ATÉ QUE SOBREVENHA LEI REGULAMENTADORA. PARÂMETROS CONCERNENTES AO EXERCÍCIO DO DIREITO DE GREVE PELOS SERVIDORES PÚBLICOS DEFINIDOS POR ESTA CORTE. CONTINUIDADE DO SERVIÇO PÚBLICO. GREVE NO SERVIÇO PÚBLICO. ALTERAÇÃO DE ENTENDIMENTO ANTERIOR QUANTO À SUBSTÂNCIA DO MANDADO DE INJUNÇÃO. PREVALÊNCIA DO INTERESSE SOCIAL. INSUBSSISTÊNCIA DO ARGUMENTO SEGUNDO O QUAL DAR-SE-IA OFENSA À INDEPENDÊNCIA E HARMONIA ENTRE OS PODERES [ART. 2O DA CONSTITUIÇÃO DO BRASIL] E À SEPARAÇÃO DOS PODERES [art. 60, § 40, III, DA CONSTITUIÇÃO DO BRASIL]. INCUMBE AO PODER JUDICIÁRIO PRODUZIR A NORMA SUFICIENTE PARA TORNAR VIÁVEL O EXERCÍCIO DO DIREITO DE GREVE DOS SERVIDORES PÚBLICOS, CONSAGRADO NO ARTIGO 37, VII, DA CONSTITUIÇÃO DO BRASIL. 1. O acesso de entidades de classe à via do mandado de injunção coletivo é processualmente admissível, desde que legalmente constituídas e em funcionamento há pelo menos um ano. 2. A Constituição do Brasil reconhece expressamente possam os servidores públicos civis exercer o direito de greve --- artigo 37, inciso VII. A Lei n. 7.783/89 dispõe sobre o exercício do direito de greve dos trabalhadores em geral, afirmado pelo artigo $9^{\circ}$ da Constituição do Brasil. Ato normativo de início inaplicável aos servidores públicos civis. 3 . O preceito veiculado pelo artigo 37 , inciso VII, da CB/88 exige a edição de ato normativo que integre sua eficácia. Reclama-se, para fins de plena incidência do 
Utilizando por analogia a mesma lógica é possível concluir que havendo um mandamento constitucional assegurando aos autônomos, parassubordinados, estagiários, residentes, entre outras espécies do gênero trabalhadores, que têm assegurado o direito de definir a oportunidade de definir o direito de greve e os interesses que por meio dele devam defender, embora não estejam tutelados na restritiva definição da Lei 7.783/89, esta se lhes deve ser aplicável até que se edite, caso se entenda ser o caso, uma lei específica para tratar a questão. Como restou consignado na ementa do acórdão do Excelso STF, "A greve, poder de fato e direito fundamental de caráter instrumental, é a arma mais eficaz de que dispõem os trabalhadores visando à conquista de melhores condições de vida, razão pela qual a sua autoaplicabilidade é inquestionável”. Após registrar que "A Constituição, ao dispor sobre os trabalhadores em geral, não prevê limitação do direito de greve: a eles

preceito, atuação legislativa que dê concreção ao comando positivado no texto da Constituição. 4. Reconhecimento, por esta Corte, em diversas oportunidades, de omissão do Congresso Nacional no que respeita ao dever, que lhe incumbe, de dar concreção ao preceito constitucional. Precedentes. 5. Diante de mora legislativa, cumpre ao Supremo Tribunal Federal decidir no sentido de suprir omissão dessa ordem. Esta Corte não se presta, quando se trate da apreciação de mandados de injunção, a emitir decisões desnutridas de eficácia. 6. A greve, poder de fato, é a arma mais eficaz de que dispõem os trabalhadores visando à conquista de melhores condições de vida. Sua auto-aplicabilidade é inquestionável; trata-se de direito fundamental de caráter instrumental. 7. A Constituição, ao dispor sobre os trabalhadores em geral, não prevê limitação do direito de greve: a eles compete decidir sobre a oportunidade de exercê-lo e sobre os interesses que devam por meio dela defender. Por isso a lei não pode restringi-lo, senão protegê-lo, sendo constitucionalmente admissíveis todos os tipos de greve. 8. Na relação estatutária do emprego público não se manifesta tensão entre trabalho e capital, tal como se realiza no campo da exploração da atividade econômica pelos particulares. Neste, o exercício do poder de fato, a greve, coloca em risco os interesses egoísticos do sujeito detentor de capital --- indivíduo ou empresa --- que, em face dela, suporta, em tese, potencial ou efetivamente redução de sua capacidade de acumulação de capital. Verifica-se, então, oposição direta entre os interesses dos trabalhadores e os interesses dos capitalistas. Como a greve pode conduzir à diminuição de ganhos do titular de capital, os trabalhadores podem em tese vir a obter, efetiva ou potencialmente, algumas vantagens mercê do seu exercício. O mesmo não se dá na relação estatutária, no âmbito da qual, em tese, aos interesses dos trabalhadores não correspondem, antagonicamente, interesses individuais, senão o interesse social. A greve no serviço público não compromete, diretamente, interesses egoísticos do detentor de capital, mas sim os interesses dos cidadãos que necessitam da prestação do serviço público. 9. A norma veiculada pelo artigo 37, VII, da Constituição do Brasil reclama regulamentação, a fim de que seja adequadamente assegurada a coesão social. 10. A regulamentação do exercício do direito de greve pelos servidores públicos há de ser peculiar, mesmo porque "serviços ou atividades essenciais" e "necessidades inadiáveis da coletividade" não se superpõem a "serviços públicos"; e vice-versa. 11. Daí porque não deve ser aplicado ao exercício do direito de greve no âmbito da Administração tão-somente o disposto na Lei n. 7.783/89. A esta Corte impõe-se traçar os parâmetros atinentes a esse exercício. 12. O que deve ser regulado, na hipótese dos autos, é a coerência entre o exercício do direito de greve pelo servidor público e as condições necessárias à coesão e interdependência social, que a prestação continuada dos serviços públicos assegura. 13. O argumento de que a Corte estaria então a legislar --- o que se afiguraria inconcebível, por ferir a independência e harmonia entre os poderes [art. 20 da Constituição do Brasil] e a separação dos poderes [art. $60, \S 4 \mathrm{o}, \mathrm{III}]$--- é insubsistente. 14. O Poder Judiciário está vinculado pelo dever-poder de, no mandado de injunção, formular supletivamente a norma regulamentadora de que carece o ordenamento jurídico. 15. No mandado de injunção o Poder Judiciário não define norma de decisão, mas enuncia o texto normativo que faltava para, no caso, tornar viável o exercício do direito de greve dos servidores públicos. 16. Mandado de injunção julgado procedente, para remover o obstáculo decorrente da omissão legislativa e, supletivamente, tornar viável o exercício do direito consagrado no artigo 37, VII, da Constituição do Brasil. (MI 712, Relator(a): Min. EROS GRAU, Tribunal Pleno, julgado em 25/10/2007, DJe-206 DIVULG 30-10-2008 PUBLIC 31-10-2008 EMENT VOL-02339-03 PP-00384). 
compete decidir sobre a oportunidade de exercê-lo e sobre os interesses que devam por meio dela defender", a mesma ementa conclui que "a lei não pode restringi-lo, senão protegê-lo, sendo constitucionalmente admissíveis todos os tipos de greve".

O ordenamento jurídico italiano já avançou neste sentido. A Lei 83/2000 estendeu os limites postos ao direito de greve também para as abstenções coletivas da prestação de serviços por parte dos trabalhadores autônomos, profissionais liberais e pequenos empreendedores ${ }^{185}$.

\subsection{O COMITÊ DE LIBERDADE SINDICAL DA OIT E O DIREITO DE GREVE}

Eric Gravel, Isabelle Duplessis e Bernard Gernigon, em publicação oficial da Organização Internacional do Trabalho (OIT), destacam que desde a criação desta em 1919, as normas internacionais do trabalho sempre foram o principal instrumento de sua ação para a promoção da justiça social. Perseguia-se através delas a melhoria geral da condição do homem no trabalho. Este recurso sistemático à adoção de instrumentos normativos com o fim de proteger os direitos do homem, característico da OIT, acabou sendo posteriormente copiado por outras organizações internacionais ${ }^{186}$.

Reconhecem os aludidos autores que o valor e o significado das normas internacionais do trabalho dependem, como passa com todas as demais normas, de sua interpretação e dos efeitos práticos que podem provocar. Buscando concretizar suas normas, a OIT criou paulatinamente diversos organismos de controle para vigiar o efeito dado às convenções e recomendações adotadas pela Conferência Internacional do Trabalho e ratificado pelos Estados na prática ${ }^{187}$.

A OIT teria se mostrado duplamente inovadora. Além do pioneirismo na utilização de instrumentos normativos que visassem melhorar as condições sociais, elaborados por uma assembleia com composição tripartite na qual figuram, em pé de igualdade, representantes governamentais, delegados de empregadores e delegados de empregados, a

\footnotetext{
${ }^{185}$ Disponível no site< http://www.camera.it/parlam/leggi/000831.htm>. Acesso em 29 de dezembro de 2010.

186 OIT. El comité de libertad syndical: impacto desde su creación. Genebra: Oficina Internacional del Trabajo, 2001, p.1.

187 OIT. El comité de libertad syndical: impacto desde su creación. Genebra: Oficina Internacional del Trabajo, 2001, p.1.
} 
OIT também foi precursora ao criar e desenvolver mecanismos de controle minuciosos com o objetivo de dar efeitos aos seus convênios e recomendações ${ }^{188}$.

Em 1926 foi criado, pela Conferência Internacional do Trabalho, o Comitê de Peritos, que já no ano seguinte celebrou sua primeira reunião para examinar os informes que devem ser submetidos periodicamente pelos governos, em conformidade com os artigos 19, 22 e 35 da Constituição da OIT. O Comitê está composto por 20 juristas independentes que se reúnem uma vez por ano em Genebra para indicar em que medida a situação de cada país está em conformidade com as convenções ratificadas. A Comissão de Aplicação de Normas da Conferência, órgão tripartite instituído em cada reunião da Conferência Internacional do Trabalho, considera o informe anual do Comitê de Expertos e convida certos governos a dar explicações sobre as divergências assinaladas pelos peritos e sobre as medidas tomadas ou a tomar para eliminá-las ${ }^{189}$.

Em 1947, a partir de iniciativas adotadas pelo Conselho Econômico e Social das Nações Unidas e preocupação com a adoção das convenções que tratam da Liberdade de Associação (ns. 87 e 98), a Conferência Internacional do Trabalho propôs a criação de um órgão especial destinado à proteção dos direitos dos sindicatos de trabalhadores. Baseandose no fato de os procedimentos contemplados pela constituição da Organização Internacional do Trabalho somente serem aplicáveis às convenções ratificadas e na importância e especificidade das questões atinentes à liberdade de associação que, por vezes, geravam problemas muito mais relacionados com questões de fato do que jurídicas, concluiu-se pela necessidade de criar um procedimento especial que pudesse ser aplicado independentemente de ratificação das Convenções que o sustentam ${ }^{190}$.

Em janeiro de 1950 o Corpo Diretivo da Organização Internacional do trabalho decidiu criar o Comitê de Investigação e Conciliação em matéria de Liberdade Sindical

\footnotetext{
188 Ibidem.

${ }^{189}$ Ibidem, p.2.

190 "In 1947, as the result of iniciatives taken by the Economic and Social Council of the United Nations and on the basis of discussions concerning the principles leading to the adoption of the basic Conventions on freedom of association (Nos. 87 e 98), the Conference adopted a resolution by which it invited the Governing body to examine the possibility of creating a special body for the protection of trade union rights. This was based on the fact that, on the one hand, the procedures contemplated in the ILO Constitution were only applicable for the ratified Conventions, and on the other, that the question of freedom of association was so important and often so specific (since the problems that arose were often more of fact than of law), that it was necessary to create a special procedure that could be applied independently of the ratification of The Conventions on the subject". (BARTOLOMEI DE LA CRUZ, Héctor; POTOBSKY, Geraldo von; SWEPSTON, Lee. The Internacional Labor Organization: The Internacional Standards . WestviewPress: Oxford, 1996, p. 99)
} 
(Fact-Finding and Conciliation Commission on Freedom of Association), definindo seus termos de referência, a base de seus procedimentos e os critérios para sua composição. Como o nome do Comitê evidencia, a sua função consiste em realizar investigações sobre a situação submetida a seu exame. Pode, por essa razão, de comum acordo com o governo interessado, examinar uma situação objetivando solucionar as dificuldades pela via do acordo. Pode submeter um caso à comissão com o consentimento prévio do governo interessado, não obstante o consentimento não seja necessário se o país interessado houver ratificado as convenções pertinentes à liberdade sindical ${ }^{191}$. O Comitê pode ainda examinar alegações relativas a violações de liberdade sindical contra Estados que não são membros da OIT, mas pertencem à Organização das Nações Unidas (ONU). Nesta última hipótese caberá ao Conselho Econômico e Social das Nações Unidas decidir se apresenta o caso ao de Investigação e Conciliação em matéria de Liberdade Sindical ${ }^{192}$. A liberdade sindical converteu-se, então, no primeiro dos direitos fundamentais a contar com um procedimento internacional de controle especializado e exclusivo ${ }^{193}$.

O Comitê funcionou pela primeira vez em 1964, mais de dez anos após a sua criação, em um caso envolvendo o Japão. Tratou, em seguida, os casos da Grécia (19651966), Lesotho (1973-1975), Chile (1974-1975), Estados Unidos/Porto Rico (1991-1992). Ao todo, a Comissão examinou seis casos durante os seus primeiros 50 anos de existência $^{194}$.

A decisão pela criação do Comitê de Investigação em Matéria Sindical foi, contudo, questionada durante a mesma sessão da Conferência, em junho de 1950. O governo da África do Sul alegou na ocasião que a conferência não deu instruções para que o Corpo Diretivo procedesse desta maneira; a Constituição da OIT não autorizara o Corpo Diretivo a criar este tipo de órgão, que poderia inclusive adotar medidas como, por exemplo, dar publicidade às reclamações se o Governo denunciado não consentisse com a investigação e que a Constituição também não autorizou a Conferência a delegar ao Corpo diretivo a criação deste órgão porque isto implicaria na substituição do procedimento

191 OIT. El comité de libertad syndical: impacto desde su creación. Genebra: Oficina Internacional del Trabajo, 2001, p.8.

192 Ibidem, p.9.

193 ERMIDA URIARTE, Oscar. Critica de la libertad sindical. Derecho Laboral - Tomo IV, n. 242, abriljunio 2011, p. 230.

${ }^{194}$ OIT. El comité de libertad syndical: impacto desde su creación. Genebra: Oficina Internacional del Trabajo, 2001, p.9. Considera-se que o número baixo de casos examinados deve-se à natural renuencia dos Estados a dar seu consentimento para o exame de um caso que lhes concerne e com maior razão ainda, quando hão hajam ratificado formalmante as convenções que protegem a liberdade sindical. (Ibidem). 
Constitucional de queixas e representações por descumprimento da aplicação das Convenções, através da instituição de um procedimento de investigação relativo a instrumentos não ratificados pelo Governo denunciado. Esses argumentos, apoiados pelo governo da Austrália, foram rejeitados sob o fundamento de que o artigo 10 da Constituição garantia amplos poderes para o corpo diretivo obter e disseminar informações, inclusive carregar investigações, com a única limitação de respeito aos direitos dos Estados. Por essa razão, o procedimento criado dependeria do consentimento do governo denunciado para que a queixa fosse submetida à Comissão. Ademais, o procedimento não envolve a aplicação de Convenções que não tenham sido ratificadas, mas apenas a promoção de um dos objetivos da OIT, qual seja a Liberdade Sindical, através de um procedimento legítimo. A Comissão não seria, segundo este entendimento, um corpo judicial, mas um órgão investigativo e conciliatório cuja missão seria verificar a verdade dos fatos alegados ${ }^{195}$.

O Comitê de Liberdade Sindical foi criado em 1951 como órgão tripartite do Conselho de Administração da OIT. Inicialmente foi instituído para proceder ao exame preliminar das alegações relativas a violações de liberdade sindical, fase preliminar de verificação para determinar se as alegações consideradas mereciam ser estudadas com mais profundidade para ser então levada à Comissão de Investigação e Conciliação. Como este foi muito pouco utilizado, o Comitê de Liberdade Sindical logo passou a proceder ao exame de fundo das queixas. Como estas não passavam em sua origem de uma etapa preliminar dentro do funcionamento interno da OIT, não foi concebida segundo o modelo do Comitê de Investigação e Conciliação. Em outras palavras esse procedimento não precisava de consentimento prévio do Estado para proceder ao exame das alegações, no

\footnotetext{
${ }^{195}$ During the same session of the Conference, in June 1950, the Governing Body's decision was questioned. The Government of South Africa alleged that: (a) the Conference had given no instructions to the Governing Body to proceed in this manner; (b) the ILO Constitution did not authorize the Governing Body to create this kind of body, which would be able to take measures (e.g., publicize complaints) if the government concerned did not consent to the investigation; and (c) the Constitution also did not allow the Conference to delegate to the Governing Body the creation of such a body, because this implied replacing the Constitutional procedure for complaints and representations for failure to apply ratified Conventions, by instituting a procedure of investigation concerning instruments not ratified by the government concerned. These arguments, supported by the Government of Australia, were rejected on the grounds that article 10, of the Constitution granted broad powers to the Governing Body to gather and disseminate information, including carrying out investigations, with the sole limitation that the rights of States be respected. For this reason, the procedure being created would require the consent of the government concerned for a complaint to be submitted to the Comission. In addition, the procedure would not involve the application of Conventions that had not been ratified, but rather the promotion of one of fact-findind and conciliation whose mission would be to verify the truth of the facts alleged (BARTOLOMEI DE LA CRUZ, Héctor; POTOBSKY, Geraldo von; SWEPSTON, Lee. The Internacional Labor Organization: The Internacional Standards . WestviewPress: Oxford, 1996, p. 99)
} 
caso de não haver sido ratificadas as convenções relativas à liberdade sindical. Esta particularidade foi conservada inclusive depois que foram adaptadas suas funções e tiveram que examinar o fundo das alegações que recebem. Com isso, o Comitê de Liberdade Sindical se converteu, em matéria de fato no principal órgão encarregado de examinar as queixas em matéria de liberdade sindical, tendo, até o princípio desse milênio, examinado quase 2.300 queixas desde sua criação ${ }^{196}$.

O Comitê de Liberdade Sindical integra o Conselho de Administração da Organização internacional do Trabalho, é composto por 9 membros sendo 3 governamentais, 3 representantes de empregados e 3 representantes de empregadores e tem por atribuição examinar queixas submetidas ao Corpo Diretivo da OIT, sempre que se considerar a averiguação justificável e o governo consentir, caso ele não tenha ratificado as convenções sobre liberdade de associação. O Comitê é presidido, desde 1978, por uma personalidade independente, ou seja, uma pessoa que não integra o Conselho de Administração. Seus membros se reúnem três vezes por ano e aprecia os casos que lhe são submetidos através, sobretudo, de provas documentais ${ }^{197}$, não obstante possa, segundo as circunstâncias do caso, ouvir as partes envolvidas com o objetivo de obter informações mais completas. Esta audiência se faz necessária quando as declarações das partes são totalmente contraditórias, com o fim de que a troca de pareceres permita apreciar a possibilidade de uma solução ou uma conciliação à luz dos princípios da liberdade sindical. Também procede no caso em que, por vislumbrar dificuldades especiais, o Comitê entender apropriado conversar diretamente com o governo interessado ${ }^{198}$.

Diversamente do que ocorre em muitos outros organismos internacionais, a competência do Comitê não depende do esgotamento prévio de todos os recursos das jurisdições nacionais. A existência de uma via de recurso nacional consiste em elemento que deve ser levado em conta pelo Comitê na sua apreciação dos fatos, mas não em requisito para a apresentação de um recurso ao Comitê $\hat{e}^{199}$.

\footnotetext{
${ }^{196}$ OIT. El comité de libertad syndical: impacto desde su creación. Genebra: Oficina Internacional del Trabajo, 2001, p.10/11.

${ }^{197}$ Ibidem, p. 11.

198 OIT. El comité de libertad syndical: impacto desde su creación. Genebra: Oficina Internacional del Trabajo, 2001, p. 17.

${ }^{199}$ É o que se extrai de mais essa relevante lição de Nicolas VALTICOS (Droit international du travail. In: CAMERLYNCK, G. H. Traité de droit du travail.Paris: Dalloz, 1970, p. 590):Cette procédure a aussi une signification plus générale du fait qu'elle a introduit, dans le domaine important de la liberté syndicale, une obligation générale de render compte de leur action pour tous les gouvernements, meme s'ils n'ont pas ratifié
} 
O procedimento especial de denúncia a este órgão colegiado e de representação paritária foi criado em 1950 e tem como uma de suas principais características o fato de ser aplicável até mesmo para os Estados que não ratificaram as convenções sobre o tema em discussão ${ }^{200}$. A queixa apreciada pelo Comitê de Liberdade Sindical da Organização Internacional do Trabalho também se notabiliza por não contemplar outro denunciado que não um estado membro da OIT ou das Nações Unidas ${ }^{201}$.

Uma vez apresentadas, as queixas são transmitidas ao governo interessado e examinadas ao mesmo tempo que os fundamentos apresentados em sua resposta pelos governos $^{202}$. O Comitê pode, sempre que o governo não apresentar seus comentários às alegações da parte querelante que lhe hão sido transmitidas, ou não responder às informações complementárias solicitadas por ele, dirigir-lhe um manifesto urgente para que o faça. Na perspectiva de que o governo não conteste este chamamento urgente, o Comitê pode então proceder ao exame do caso sem a participação do querelado.

Nenhum representante ou nacional do Estado interessado e nenhuma pessoa que tenha um cargo oficial na organização internacional de empregadores ou de trabalhadores que apresentou a queixa pode participar nos trabalhos do Comitê ou estar presente quando este examina o caso ${ }^{203}$.

Por fim, é preciso reconhecer que as sanções aplicáveis pelo Comitê de Liberdade Sindical, assim como sói ocorrer com os organismos internacionais em geral são

les conventions en la matière. Cette responsabilité international des Etats et leur souci d'eviter des critiques ont pu influer sur leur action, prévenir ou limiter des abus et inspirer des changements de politiques.

${ }^{200}$ É o que evidencia Ericson CRIVELLI(Direito internacional do trabalho contemporâneo. São Paulo: LTr, 2010, p. 88), ao asseverar que "Os procedimentos internos adotados têm regras de admissibilidade mais flexíveis que os demais mecanismos contenciosos de controle existentes na OIT. Admite a apresentação de reclamação por organizações que não tenham âmbito de representação nacional e, ainda que o Estadomembro acusado de violação não tenha ratificado a Convenção específica sobre liberdade sindical, o Comitê considera a sua garantia uma exigência constitucional oriunda da declaração de Filadélfia".

${ }^{201}$ É o que se extrai das sempre precisas lições de Nicolas VALTICOS (Droit international du travail. In: CAMERLYNCK, G. H. Traité de droit du travail.Paris: Dalloz, 1970, p. 587/588): "Une importante particularité de cette procedure est qu'elle est applicable même à des États qui n'ont pas ratifié les conventions sur la liberté syndicale. A leur égard la procédure se fonde essentielement sur les obligations découlant de leur qualité de membres de l'Organisation et sur le fait que la Constitution de l'OIT, completée par la Déclaration de Philadelphie de 1944, consacre le príncipe de la liberté syndicale. On a souligné que, si les objectifs de l'Organisation ne peuvent être imposés à des Etats n'ayant pas ratifié une convention, il est possible d'en promovoir la réalisation par d'autres moyens et notamment par des organes d'enquête et de conciliation".

${ }^{202}$ OIT. El comité... op cit, p. 12.

${ }^{203}$ OIT. El comité de libertad syndical: impacto desde su creación. Genebra: Oficina Internacional del Trabajo, 2001, p. 12. 
exclusivamente de ordem moral. Elas visam influenciar ações futuras dos estados, prevenir e limitar abusos e inspirar mudanças nas políticas do país em questão ${ }^{204}$. Considera-se, entretanto, que, em uma época marcada pela transmissão de informações em tempo real, aos governos lhes desagrada cada vez mais ver suas transgressões e o descumprimento de suas obrigações internacionais ventiladas publicamente. Esta talvez seja a razão do sucesso festejado pela Organização Internacional do Trabalho, em seu material de esclarecimentos acerca do Comitê de Liberdade Sindical, ao constatar que em um período de 25 anos, mais de 60 países de cinco continentes, em um ou outro momento, tomaram medidas como consequência das recomendações do Comitê ou lhes informaram acerca de fatos positivos em matéria de liberdade sindical ocorridos em seu território, relacionados com as queixas examinadas pelo Comitêt $\hat{e}^{205}$.

Não se pode, portanto, negar a sua importância enquanto provedoras de subsídios interpretativos para os limites do direito de greve e outras questões relacionadas direta ou indiretamente com o princípio da liberdade sindical. Esta importância restou evidenciada por Orlandini, segundo quem, como o direito de greve não é objeto de expresso reconhecimento por nenhuma das fontes da Organização Internacional do Trabalho, é apenas graças à atividade interpretativa do Comitê de Liberdade Sindical que são elaborados os padrões internacionais deste direito inserido implicitamente na Convenção 87 da Organização Internacional do Trabalho ${ }^{206}$.

\subsubsection{O direito de greve no Brasil sob a perspectiva do Comitê de Liberdade Sindical da OIT}

\footnotetext{
${ }^{204}$ É o que se extrai de mais essa relevante lição de Nicolas VALTICOS (Droit international du travail. In: CAMERLYNCK, G. H. Traité de droit du travail.Paris: Dalloz, 1970, p. 590): "Cette procédure a aussi une signification plus générale du fait qu'elle a introduit, dans le domaine important de la liberté syndicale, une obligation générale de render compte de leur action pour tous les gouvernements, meme s'ils n'ont pas ratifié les conventions en la matière. Cette responsabilité international des Etats et leur souci d'eviter des critiques ont pu influer sur leur action, prévenir ou limiter des abus et inspirer des changements de politiques".

${ }^{205}$ OIT. El comité... op cit, p.23.

${ }^{206}$ E d'altra parte il diritto di sciopero non è oggetto di espresso riconoscimento neppure nelle fonti OIL; è solo grazie all'attività interpretativa del Comitato sulla liberta di associazione (Freedom of Association Committee of the Governing body of the ILO) che sono stati elaborati standard internazionali di tutela dello stesso, dedotti implicitamente dalla Convenzione n. 87/1948 sulla libertá di associazione. (ORLANDINI, Giovanni. Sciopero e servizi pubblici essenciali nel processo d'integrazione europea: uno Studio di diritto comparato e comunitário. Torino: Giappichelli editore: 2003, p. 21).
} 
Em pesquisa já publicada ${ }^{207}$, analisou-se a compatibilidade entre a Lei n. 7783/89 e o mais recente repertório de precedentes do Comitê de Liberdade Sindical. A conclusão, a que se chegou é a de que a lei de greve atualmente vigente no Brasil, editada no auge da redemocratização do país, mostra-se compatível com a jurisprudência do Comitê de Peritos.

Ao assegurar o direito de greve, atribuindo aos trabalhadores competência para decidir sobre a oportunidade de exercê-lo e sobre os interesses que devam por meio dele defender, exigindo, contudo, para que o movimento paredista seja considerado legítimo, que, em linhas gerais, seja realizado de modo pacífico, que tenha início apenas após frustrada a negociação ou verificada a impossibilidade de recursos a via arbitral, que seja autorizado por assembléia, convocada na forma do estatuto da entidade sindical, e que seja divulgado com antecedência, o legislador brasileiro adotou procedimentos posteriormente respaldados na $5^{\mathrm{a}}$ edição da Recopilación de decisiones y princípios del Comité de Libertad Sindical del Consejo de Administración de la OIT .

O mesmo pode ser dito em relação aos dispositivos da legislação brasileira que asseguram aos grevistas, entre outros direitos, o emprego de meios pacíficos tendentes a persuadir ou aliciar os trabalhadores, a arrecadação de fundos e a livre divulgação do movimento, mas, em contrapartida, para evitar abusos, exigem que, em nenhuma hipótese, os meios adotados por empregados e empregadores violem ou constranjam os direitos e garantias fundamentais de outrem e que as manifestações e atos de persuasão utilizados pelos grevistas não impeçam o acesso ao trabalho nem causem ameaça ou dano à propriedade ou pessoa.

Cabe aqui mencionar, exemplificativamente, o precedente enumerado como 549, segundo o qual não se pode considerar atentatória à liberdade sindical uma legislação que preveja procedimentos de conciliação e arbitragem vonluntária nos conflitos coletivos como condição prévia à declaração de greve ${ }^{208}$. O artigo $3^{\circ}$ da Lei 7.783/90, que somente

\footnotetext{
${ }^{207}$ BOUCINHAS FILHO, Jorge Cavalcanti. Responsabilidade civil dos sindicatos em situações de exercício abusivo do direito de greve e de violência durante a paralisação coletiva. Revista síntese trabalhista $e$ previdenciária, $n .269$, novembro 2011 , p. 39 à 61 .

${ }^{208}$ Precedente 549 da 5 a edição da Recopilación de decisiones y princípios del Comité de Libertad Sindical del Consejo de Administración de la OIT que assim dispõe: "No puede considerarse como atentatoria a la libertad sindical una legislación que prevé procedimientos de conciliación y arbitraje (voluntario) en los conflictos colectivos como condición previa a la declaración de una huelga siempre y cuando el recurso al arbitraje no tenga carácter obligatorio y no impida en la práctica el recurso a la huelga". (Véanse Recopilación de 1996, párrafo 500; 307. informe, caso núm. 1899, párrafo 83, caso núm. 1898, párrafo 324;
} 
admite a cessação coletiva do trabalho após frustrada a negociação ou verificada a impossibilidade de recursos via arbitral, mostra-se, portanto, em consonância com o entendimento adotado pelo Comitê de Liberdade Sindical ${ }^{209}$, como já se afirmou ${ }^{210}$.

Como também se concluiu no estudo ao qual aqui se faz referência ${ }^{211}$, o precedente 552 considera admissível a exigência de pré-aviso ao empregador antes da declaração de greve $^{212}$ respaldando, outrossim, o parágrafo único do artigo $3^{\circ}$ da Lei de Greve em vigor no Brasil ${ }^{213}$. O seguinte, no entanto, deixa claro, ao censurar governo que instituiu em suas dependências a exigência de pré-aviso de 20 dias, que o prazo estipulado deve ser razoável $^{214}$.

Também se pode constatar em pesquisa $\operatorname{prévia}^{215}$ que no tocante ao quórum necessário para autorização da greve pela categoria é possível afirmar que a legislação brasileira, que permite que o sindicato estabeleça em seu estatuto o quórum necessário para deliberação acerca do início e do término do movimento paredista, mostra-se em perfeita harmonia com o conceito de liberdade sindical desenvolvido pela OIT (art. $4^{\circ}, \S 1^{\circ}$ da Lei de Greve). Em verdade, a lei brasileira foi além do exigido pelo Comitê de Liberdade Sindical na medida em que este registrou certa feita a possibilidade de o quórum em questão ser estabelecido na própria legislação ${ }^{216}$.

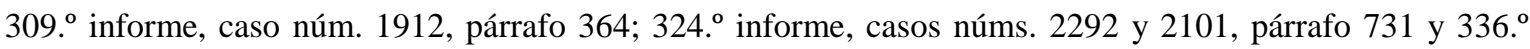
informe, caso núm. 2369, párrafo 212.)

${ }^{209}$ BOUCINHAS FILHO, Jorge Cavalcanti. Responsabilidade civil dos sindicatos em situações de exercício abusivo do direito de greve e de violência durante a paralisação coletiva. Revista síntese trabalhista $e$ previdenciária, $n$. 269, novembro 2011, p. 54.

${ }^{210}$ Idem, p. 54.

${ }^{211}$ Idem, p. 55.

212 Precedente 552 da $5^{\mathrm{a}}$ edição da Recopilación de decisiones y princípios del Comité de Libertad Sindical del Consejo de Administración de la OIT que assim dispõe: "La obligación de dar un preaviso al empleador o a su organización antes de declarar una huelga puede ser considerada como admisible." (Véase Recopilación de 1996, párrafo 502; 325. informe, caso núm. 2049, párrafo 520 y 333.er informe, caso núm. 2251, párrafo 996.)

${ }^{213}$ Parágrafo único - A entidade patronal correspondente ou os empregadores diretamente interessados serão notificados, com antecedência mínima de 48 (quarenta e oito) horas, da paralisação.

${ }^{214}$ Precedente 553 da 5 a edição da Recopilación de decisiones y princípios del Comité de Libertad Sindical del Consejo de Administración de la OIT que assim dispõe: "El requisito de un preaviso de 20 días no atenta contra los principios de la libertad sindical en los servicios de interés social o público." (Véase Recopilación de 1996 , párrafo $504 ; 309 .^{\circ}$ informe, caso núm. 1912, párrafo 365.).

${ }^{215}$ BOUCINHAS FILHO, Jorge Cavalcanti. Responsabilidade civil dos sindicatos em situações de exercício abusivo do direito de greve e de violência durante a paralisação coletiva. Revista síntese trabalhista $e$ previdenciária, $n$. 269, novembro 2011, p. 55.

${ }^{216}$ Precedente 559 da $5^{\text {a }}$ edição da Recopilación de decisiones y princípios del Comité de Libertad Sindical del Consejo de Administración de la OIT que assim dispõe: "La obligación de respetar un determinado quórum y de tomar la decisión de hacer huelga por medio de escrutinio secreto puede considerarse admisible." (Véanse Recopilación de 1996, párrafo 510; 316. ${ }^{\circ}$ informe, caso núm. 1989, párrafo 190 y $332 .^{\circ}$ informe, caso núm. 2216, párrafo 912). 
Os artigos $9^{\circ}$ a 13 , da Lei de Greve, disciplinam a necessidade de manutenção de determinadas atividades, mesmo durante a greve. Busca-se assegurar a continuidade dos serviços cuja paralisação provoque prejuízo irreparável, pela deterioração irreversível de bens, máquinas e equipamentos; bem como a manutenção daqueles essenciais à retomada das atividades da empresa, quando da cessação do movimento, além de disciplinar o exercício do direito de greve em atividades essenciais. Todas essas exigência, mais uma vez, mostram-se em conformidade com os precedentes elencados na $5^{\text {a }}$ edição da Recopilación de decisiones y princípios del Comité de Libertad Sindical del Consejo de Administración de la OIT, consoante estudo ao qual se faz referência nesse ato ${ }^{217}$.

O mesmo texto ${ }^{218}$ destaca ainda que no precedente compilado sob n. 581, o Comitê sublinha que o critério determinante para se definir os casos em que a greve pode ser proibida é a existência de uma ameaça evidente para a vida, a segurança e ou a saúde de toda ou de parte da população ${ }^{219}$. No seguinte, o Comitê de Liberdade sindical destacou que um serviço não essencial pode se converter em serviço essencial quando a duração da greve se prolonga demasiadamente e põe em perigo a vida, a segurança da pessoa ou a saúde de toda ou de parte da população ${ }^{220}$.

Observou-se ainda, a partir do estudo empreendido no repertório do Comitê de Liberdade Sindical da OIT a existência de diversos precedentes do Comitê tratando dos serviços essenciais, para incluir nesta categoria figuras muito próximas às que são tuteladas

\footnotetext{
${ }^{217}$ BOUCINHAS FILHO, Jorge Cavalcanti. Responsabilidade civil... op cit, p. 55.

${ }^{218}$ Ibidem, p. 55/56.

${ }^{219}$ Precedente 581 da $5^{\mathrm{a}}$ edição da Recopilación de decisiones y princípios del Comité de Libertad Sindical del Consejo de Administración de la OIT que assim dispõe: "Para determinar los casos en los que podría prohibirse la huelga, el critério determinante es la existencia de una amenaza evidente e inminente para la vida, la seguridad o la salud de toda o parte de la población.” (Véanse Recopilación de 1996, párrafo 540; $320 .^{\circ}$ informe, caso núm. 1989 , párrafo $324 ; 324 .^{\circ}$ informe, caso núm. 2060, párrafo $517 ; 329 .^{\circ}$ informe, caso núm. 2195 , párrafo $737 ; 332 .^{\circ}$ informe, caso núm. 2252, párrafo $883 ; 336$. $^{\circ}$ informe, caso núm. 2383, párrafo 766 ; $338 .^{\circ}$ informe, caso núm. 2326, párrafo 446 y caso núm. 2329, párrafo 1275.$)$

${ }^{220}$ Precedente 582 da $5^{\text {a }}$ edição da Recopilación de decisiones y princípios del Comité de Libertad Sindical del Consejo de Administración de la OIT que assim dispõe: "Lo que se entiende por servicios esenciales en el sentido estricto de la palabra depende en gran medida de las condiciones propias de cada país. Por otra parte, este concepto no es absoluto puesto que un servicio no esencial puede convertirse en servicio esencial cuando la duración de una huelga rebasa cierto período o cierto alcance y pone así en peligro la vida, la seguridad de la persona o la salud de toda o parte de la población." (Véanse Recopilación de 1996, párrafo 541; $320 .^{\circ}$ informe, caso núm. 1963, párrafo 229; 321.er informe, caso núm. 2066, párrafo 340; 330. informe, caso núm. 2212, párrafo 749; 335. ${ }^{\circ}$ informe, caso núm. 2305, párrafo 505 y 338. ${ }^{\circ}$ informe, caso núm. 2373, párrafo 382.) 10. Derecho de huelga La libertad sindical - Quinta edición (revisada)
} 
na legislação brasileira em vigor ${ }^{221}$. O de número 585 considerou plausível a inclusão, como serviços essenciais, daqueles desempenhados no setor hospitalar, os serviços de eletricidade, abastecimento de água, serviços telefônicos, polícia e forças armadas, serviços de bombeiros, serviços penitenciários públicos ou privados, fornecimento de alimentos a alunos em idade escolar e limpeza de estabelecimentos escolares e controle de tráfego aéreo $^{222}$. Este último, aliás, merece especial destaque com a edição de um precedente específico no qual se consignou que a sua essencialidade se aplica para qualquer forma de greve, incluindo-se nesse conceito as greves de braços caídos e outras, haja vista que estas podem ser tão perigosas para a vida, segurança pessoal e saúde da totalidade ou de parte da população, quanto as greves tradicionais ${ }^{223}$.

Ressaltou-se, contudo, no estudo publicado ${ }^{224}$, que o Comitê teve o cuidado de enfatiza que as condições estabelecidas pela legislação para que a greve seja considerada

${ }^{221}$ BOUCINHAS FILHO, Jorge Cavalcanti. Responsabilidade civil dos sindicatos em situações de exercício abusivo do direito de greve e de violência durante a paralisação coletiva. Revista síntese trabalhista $e$ previdenciária, $n$. 269, novembro 2011, p. 54.

${ }^{222}$ Precedente 585 da $5^{\text {a }}$ edição da Recopilación de decisiones y princípios del Comité de Libertad Sindical del Consejo de Administración de la OIT que assim dispõe: "Pueden ser considerados como servicios esenciales: - el sector hospitalario (véanse Recopilación de 1996, párrafo 544; 300 informe, caso núm. 1818, párrafo $366 ; 306 .^{\circ}$ informe, caso núm. 1882 , párrafo $427 ; 308 .^{\circ}$ informe, caso núm. 1897 , párrafo $477 ; 324 .^{\circ}$ informe, caso núm. 2060, párrafo 517, caso núm. 2077, párrafo 551; 329. informe, caso núm. 2174, párrafo 795; 330. informe, caso núm. 2166, párrafo 292 y 338. informe, caso núm. 2399, párrafo 1171); - los servicios de electricidad (véanse Recopilación de 1996, párrafo 544; 308. informe, caso núm. 1921, párrafo 573; 309. ${ }^{\circ}$ informe, caso núm. 1912, párrafo 365, 318. ${ }^{\circ}$ informe, caso núm. 1999, párrafo 165 y caso núm. 1944, párrafo 458); - los servicios de abastecimiento de agua (véanse Recopilación de 1996, párrafos 544 y 326. informe, caso núm. 2135, párrafo 267); - los servicios telefónicos (véanse Recopilación de 1996, párrafo 544; 314. ${ }^{\circ}$ informe, casos núms. 1984 y 1955, párrafo 72 y 318. ${ }^{\circ}$ informe, caso núm. 2020, párrafo 318 ); - la policía y las fuerzas armadas (véase $307^{\circ}$ informe, caso núm. 1898, párrafo 323); - los servicios de bomberos (véanse 309. informe, caso núm. 1865, párrafo 145 y 321.er informe, caso núm. 2066, párrafo 336); - los servicios penitenciarios públicos o privados (véase $336 .^{\circ}$ informe, caso núm. 2383, párrafo 767); el suministro de alimentos a los alumnos en edad escolar y la limpieza de los establecimientos escolares (324. informe, caso núm. 2037, párrafo 102); - el control del tráfico aéreo (véanse Recopilación de 1996, párrafo 544 y 327. informe, caso núm. 2127, párrafo 191)”.

${ }^{223}$ Precedente 586 da $5^{\mathrm{a}}$ edição da Recopilación de decisiones y princípios del Comité de Libertad Sindical del Consejo de Administración de la OIT que assim dispõe: “El principio según el cual el control del tráfico aéreo puede considerarse como un servicio esencial se aplica a todas las huelgas, cualquiera que sea su forma - huelga de brazos caídos, trabajo a reglamento, ausencia por supuesta enfermedad, etc. - dado que éstas pueden ser tan peligrosas como una huelga tradicional para la vida, la seguridad personal o la salud de la totalidad o parte de la población". (Véase 327. informe, caso núm. 2127, párrafo 191.)

${ }^{224}$ Precedente 586 da $5^{\mathrm{a}}$ edição da Recopilación de decisiones y princípios del Comité de Libertad Sindical del Consejo de Administración de la OIT que assim dispõe: “El principio según el cual el control del tráfico aéreo puede considerarse como un servicio esencial se aplica a todas las huelgas, cualquiera que sea su forma - huelga de brazos caídos, trabajo a reglamento, ausencia por supuesta enfermedad, etc. - dado que éstas pueden ser tan peligrosas como una huelga tradicional para la vida, la seguridad personal o la salud de la totalidad o parte de la población”. (Véase 327. informe, caso núm. 2127, párrafo 191.) 
um ato lícito devem ser razoáveis, não podendo implicar em limitação importante às possibilidades de ação das organizações sindicais ${ }^{225}$.

\subsubsection{Reflexão sobre o atual entendimento do Comitê de Liberdade Sindical no tocante à greve}

Como já salientado, concluiu-se, ao final do estudo realizado, que a legislação brasileira, elaborada durante o clímax do processo de redemocratização do país, mostra-se adequada aos ditames do Comitê de Liberdade Sindical da Organização Internacional do Trabalho, sobre exercício do direito de greve ${ }^{226}$. Cabe, doravante, questionar se isso efetivamente é algo positivo.

Primeiramente há que se reconhecer, como já salientado em item anterior, que diante da falta de uma Convenção Internacional dedicado ao direito de greve, o papel orientador dos legisladores dos países membros da Organização Internacional do Trabalho vem sendo desempenhado pelos repertórios de decisões do Comitê de Liberdade Sindical. Como salientam Eric Gravel, Isabelle Duplessis e Bernard Gernigon, em material oficial da OIT, o Comitê de Liberdade Sindical elaborou um conjunto importante de princípios em matéria de liberdade sindical e assumiu uma função preventiva, permitindo que a todo momento os Estados possam se referir aos princípios desenvolvidos pelo Comitê em matéria de liberdade sindical a fim de modificar ou adotar uma disposição legislativa, ou resolver uma situação de fato contrária a esses princípios.

Há que se ponderar, por outro lado, se o repertório que está efetivamente sendo divulgado pelo mencionado órgão é fruto de um debate efetivo e democrático em que representantes dos governos participam em igualdade de condições com os representantes dos empregados e dos empregadores, ou se ele reflete a predominância de uma ideologia e de um meio de produção dominante.

\footnotetext{
${ }^{225}$ Precedente 547 da $5^{\text {a }}$ edição da Recopilación de decisiones y princípios del Comité de Libertad Sindical del Consejo de Administración de la OIT que assim dispõe: "Las condiciones requeridas por la legislación para que la huelga se considere un acto lícito deben ser razonables y, en todo caso, no de tal naturaleza que constituyan una limitación importante a las posibilidades de acción de las organizaciones sindicales". (Véanse Recopilación de 1996, párrafo 498; 300. informe, caso núm. 1799, párrafo 207; 318. ${ }^{\circ}$ informe, caso núm. 2018, párrafo 514; $325 .^{\circ}$ informe, caso núm. 2049, párrafo 520; $327 .^{\circ}$ informe, caso núm. 2118, párrafo 635 y 333.er informe, caso núm. 2251, párrafo 995.)

${ }^{226}$ BOUCINHAS FILHO, Jorge Cavalcanti. Responsabilidade civil dos sindicatos em situações de exercício abusivo do direito de greve e de violência durante a paralisação coletiva. Revista síntese trabalhista $e$ previdenciária, n. 269, novembro 2011, p. 57.
} 
Após destacar a descomunal importância atribuída pela OIT à liberdade sindical, Oscar Ermida Uriarte dirige uma série de críticas ao Comitê de Liberdade Sindical. Primeiramente ele se insurge contra o fato de as pessoas físicas, ainda quando sujeitos passivos de ataque à sua liberdade sindical, carecerem de legitimação para acionar ante o Comitê de Liberdade Sindical. Em sua opinião, "desde el punto de vista estrictamente técnico, pareceria que la protección de um derecho fundamental exigiria una legitimación activa, más extensa, inclusive de la persona física" ${ }^{\text {227 }}$. Em segundo lugar ele critica o conservadorismo da jurisprudência atual do Comitê e analisa suas razões e sua origem.

Segundo Ermida Uriarte, apesar de ter nascido com uma série de particularidades revolucionárias para o Direito Internacional da época, seguido por uma rápida e intensa legiferação que a converteram, até a década de 70, na grande e quase única protagonista do Direito Internacional claramento protetor do trabalhador e limitativo, dentro do possível, do dumping social, a OIT ingressou, nos últimas duas décadas do século $\mathrm{XX}$, em um claro movimento de enfraquecimento e decadência ${ }^{228}$.

Este processo teria, segundo o jurista uruguaio, múltiplas causas. Primeiramente a queda do "socialismo real" teria modificado radicalmente o equilíbrio das forças dentro da organização, em prejuízo das posições do grupo dos trabalhadores. Isto porque até os anos oitenta os países do leste europeu frequentemente votavam em bloco nos órgãos tripartites da OIT (em especial na Conferência e no Conselho de Administração), alinhados com as posições dos trabalhadores. Assim o faziam os delegados dos sindicatos, dos governos e dos empregadores, já que estes eram funcionários do Estado. Após o fim da guerra fria e a queda do muro de Berlim, esta situação se modificou rapidamente. Os países do leste europeu passaram a se situar mais a direita que vários dos países da Europa Ocidental. Seus empresários passaram a se alinhar com o grupo empregador e a maior parte de seus governos adotam posições próximas à destes. Com isso, a equação de poder passa a ser claramente desfavorável aos trabalhadores ${ }^{229}$.

\footnotetext{
${ }^{227}$ ERMIDA URIARTE, Oscar. Critica de la libertad sindical. Derecho Laboral - Tomo IV, n. 242, abriljunio 2011,p. 233/234.

228 Ibidem, p. 234.

${ }^{229}$ ERMIDA URIARTE, Oscar. Critica de la libertad sindical. Derecho Laboral - Tomo IV, n. 242, abriljunio 2011, p. 234/ 235.
} 
Este processo, segundo Uriarte, coincide e se retroalimenta com a entronização mundial do "pensamento único" em matéria econômica. Em sua opinião, não apenas os empresários como também muitos governos teriam abraçado, expressa ou tacitamente, muitos dos postulados econômicos neoliberais, que, como se sabe, implicam na pretensão desreguladora ou flexibilizadora em matéria laboral. Com isso, as mesmas forças (patronais e governamentais) que propunham e às vezes impunham as políticas de desregulação e flexibilização no ordenamento jurídico nacional, também o impulsionaram e em boa medida o impuseram no ordenamento jurídico da OIT. O autor uruguaio chega a mencionar em seu texto situações em que não apenas os governos, mas até delegados dos trabalhadores dos países industrializados se viram inclinados a fazer concessões normativas, por entenderem que os pisos dessas normas mínimas já não lhes eram necessários, haja vista os níveis alcançados por suas legislações nacionais e pela normativa comunitária $^{230}$.

As manifestações de enfraquecimento da Organização Internacional do Trabalho poderiam ser identificadas na chamada "pausa normativa" ou enlentecimento do ritmo de aprovação de convenções, a preferência por recomendações, a revisão de alguns convênios em prejuízo dos trabalhadores, a inédita recusa do projeto de convenção sobre subcontratação na Conferência de 1998, certa flexibilização do sistema de controle, o paradoxo de manter uma visão limitada dos efeitos de suas normas e dos pronunciamentos de seus órgãos de controle enquanto algumas tendências jurisprudenciais nacionais e internacionais lhe atribuem maior preceptividade ${ }^{231}$.

É neste contexto que o autor citado identifica um certo processo de “conservadorização" da jurisprudência do Comitê de Liberdade Sindical, que não é um fato isolado, senão algo que deve ser analisado no contexto antes indicado. $\mathrm{O}$ autor faz então uma comparação entre a $4^{\mathrm{a}}$, datada de 1996, e a $5^{\mathrm{a}}$ edição, datada de 2006, da Recompilação de Decisões do Comitê de Liberdade Sindical.

Um dos temas em que o autor identificou mudança mais facilmente perceptível foi na greve nos serviços essenciais. Os pronunciamentos recompilados na $4^{\mathrm{a}}$ edição apenas previam duas classes de serviços essenciais em que seria possível limitar e, às vezes até proibir o exercício do direito de greve, quais sejam os serviços essenciais stricto sensu,

\footnotetext{
${ }^{230}$ Ibidem, p. 235 .

${ }^{231}$ Ibidem, p. 236
} 
entendidos como aqueles cuja interrupção sempre põe em perigo a vida, a saúde ou segurança de toda ou parte da população e os serviços essenciais em sentido lato, que são aqueles que sem ser essenciais em si mesmos porque sua suspensão não põe imediatamente em perigo a vida, saúde ou segurança, podem se tornar essenciais pelo prolongamento da afetação. A quinta edição da recompilação trouxe, ao lado destas duas, uma terceira categoria na qual o Comitê entende adequada a limitação da greve como se foram serviços essenciais. São os serviços públicos de importância transcendental, categoria que, como se percebe facilmente, hipertrofia severamente as hipóteses de tolerância à limitação do direito fundamental de greve. Por meio desta via, o Comitê passou a admitir restrições ao exercício do direito de greve em atividades em que antes as rechaçava, como por exemplo, as de transporte coletivo urbano de passageiros, metrôs e túneis subterrâneos, a do transporte ferroviário, a do transporte de mercadorias, a do correo, a educação, os serviços de saúde animal e até a do instituto monetário, os bancos, os transportes e os setores de petróleo $^{232}$.

Situação similar pode ser identificada no tocante às chamadas formas atípicas de greve. Após considerar durante décadas que a ocupação era uma forma de exercício do direito de greve, o Comitê mudou de entendimento e consignou em sua última recompilação de decisões que se deve permitir o trabalho dos não grevistas e o acesso da direção da empresa, o qual, como se acentuou, priva a ocupação de seu sentido e finalidade ${ }^{233}$.

Ermida Uriarte critica ainda, em sua análise acerca dos mais recentes precedentes do Comitê de Liberdade Sindical, a maior predisposição do aludido organismo a admitir queixas dos empregadores por violação de sua liberdade sindical. Afirma ele que anos atrás era raro um empresário apresentar queixa ao Comitê de Liberdade Sindical e as poucas que apresentadas não tiveram êxito. Há alguns anos, contudo, essa situação vem se modificando. Segundo o jurista uruguaio haveria uma campanha da Organização Internacional de Empregadores (OIE) para apresentar reclamações e pressionar para obter pronunciamentos favoráveis, em uma estratégia tendente a reafirmar a bilateralidade da liberdade sindical, a compensar a idéia de que o empregador é o natural infrator da liberdade sindical aparecendo, ao menos as vezes, como lesionado, debilitando assim a

\footnotetext{
${ }^{232}$ Idem, p. 237.

${ }^{233}$ Ibidem.
} 
posição dos trabalhadores. Segundo Uriarte, o Comitê vem mostrando certa complacência com esta ofensiva patronal ${ }^{234}$.

Percebe-se, outrossim, que no cenário atual, o fato de a legislação brasileira estar dm sintonia com o que o Comitê de Liberdade Sindical da Organização Internacional do Trabalho considera adequado em matéria de direito de greve não significa, por si só, que ela seja insuscetível de críticas.

Não obstante tenha representado avanço em relação à norma que a precedeu, como salientado alhures, a Lei 7.783 não se mostra adequada aos tempos atuais em que a tecnologia e as novas formas de gestão comercial mudaram as relações de trabalho, enfraqueceram o movimento sindical e a greve enquanto instrumento de conquistas sociais. Quiça não fosse adequada sequer para o contexto histórico em que fora promulgada.

\subsection{LIMITAÇÕES AO DIREITO DE GREVE}

No Brasil, o constituinte de 1988 disciplinou a greve com bastante amplitude, mas não o concebeu como direito absoluto ${ }^{235}$. Segundo Ari Possidônio Beltran, a greve, consiste no mais poderoso instrumento de pressão dos trabalhadores, mas traz ao mesmo tempo a contrapartida dos limites e condições de seu exercício. E complementa aduzindo que "Toda a gama de meios de ação que a envolvem, sejam modalidades afins ou não, aplicadas de forma isolada ou em conjunto, como reforço do movimento paredista, podem celeremente transpor as fronteiras do abuso de direito" 236 .

Com efeito, o direito de greve, reconhecido juridicamente tanto pelo ordenamento brasileiro como pela Organização Internacional do Trabalho (OIT) não consiste em direito absoluto. Até porque não há direitos absolutos.

O Comitê de Liberdade Sindical não discrepa e reconhece a possibilidade de restrição ao exercício do direito de greve, pela via legal. O precedentes n. 547 da $5^{\text {a }}$ edição

\footnotetext{
${ }^{234}$ Idem.

${ }^{235}$ Nesse sentido vem se posicionando também a jurisprudência dos tribunais do trabalho: "O direito de greve não é absoluto nem irrestrito - Também aos sindicatos se aplica o princípio geral de direito consoante o qual o direito de cada um vai até onde começa o direito de outrem".(TRT 12a Região - DC 0523/91 - (Ac.TP 0613/92, 12.3.92) - Rel. Juiz Victório Ledra - Revista LTr 56-11/1370)

${ }^{236}$ BELTRAN, Ari Possidônio. A autotutela nas relações de trabalho. São Paulo: LTr, 1996, p. 203.
} 
da Recopilación de decisiones y princípios del Comité de Libertad Sindical del Consejo de Administración de la OIT mostra-se bastante esclarecedor:

547. Las condiciones requeridas por la legislación para que la huelga se considereun acto lícito deben ser razonables y, en todo caso, no de tal naturaleza que constituyan una limitación importante a las posibilidades de acción de las organizaciones sindicales.(Véanse Recopilación de 1996, párrafo $498 ; 300 .^{\circ}$ informe, caso núm. 1799 , párrafo 207; $318 .^{\circ}$ informe, caso núm. 2018, párrafo $514 ; 325 .^{\circ}$ informe, caso núm. 2049, párrafo $520 ; 327 .^{\circ}$ informe, caso núm. 2118, párrafo 635 y 333.er informe, caso núm. 2251, párrafo 995.)

O precedente em questão deixa claro que o Comitê de Peritos admite que a legislação nacional estabeleça condições para o exercício do direito de greve. É claro que essas condições devem ser razoáveis e não podem implicar limitações importantes às possibilidades de ação das organizações sindicais. A conclusão, no fundo, vai de encontro a opinião de Paulo Garcia, segundo quem, “Todos sabem e reconhecem que no decorrer de uma greve podem surgir atos delituosos que merecem punição. Cumpre ao legislador prever tais casos. A primeira providência legal será a de punir toda e qualquer violência contra pessoas e coisas"237. Márcio André Medeiros Moraes, destaca, enaltecendo a importância de se regulamentar as limitações ao direito de greve, que "Deixar o exercício desse direito, que é um direito social, sem qualquer parâmetro para o seu exercício, é o mesmo que acender um estupim de dinamite e acreditar que não vai explodir" ${ }^{\text {,238. }}$.

Mesmo os que um dia defenderam a greve como direito absoluto admitiam limitações ao seu exercício e a sujeição de quem as descumprisse a sanções de ordem penal, como evidencia Louis Josserand:

A tese do direito absoluto, tem contado com defensores desejosos de fazer do direito de greve um direito sagrado, um superdireito, pois para eles a greve levaria em si mesma sua própria justificação, sua própria legitimidade, salvo se ela não estiver acompanhada de manobras que caiam sob a lei penal ${ }^{239}$.

\footnotetext{
${ }^{237}$ GARCIA, Paulo. Direito de Greve. Rio de Janeiro: Edições Trabalhistas, 1961, p. 151.

${ }^{238}$ MORAES, Márcio André Medeiros. A responsabilidade civil do sindicato perante o consumidor. 2001. 377 f. Tese (doutorado em Direito das Relações Sociais - Direito Civil). Pontíficia Universidade Católica de São Paulo, São Paulo, 2001, p 108.

${ }^{239}$ Apud GARCIA, Paulo. Direito de greve. Rio de janeiro: Edições Trabalhistas, 1961, p 151.
} 
O Min. João Oreste Dalazen, na condição de Corregedor-Geral da Justiça do Trabalho, destacou, ao proferir decisão liminar na reclamação correicional tombada com o número TST-200643/2008-000-00-00.2, que “A própria Declaração Universal dos Direitos do Homem, cujo sexagésimo aniversário comemoramos em 2008, proclamou que o direito de greve deve ser 'exercido de conformidade com as leis de cada país', que podem prever limitações 'para proteção dos direitos e liberdades de outrem' (art. $8^{\circ}$, alíneas $c$ e $d$, do Pacto Internacional dos Direitos Econômicos Sociais e Culturais - N.Y., 1966)" 240.

Como bem salientou o doutrinador italiano Michele Vacca, uma greve sem limitação significaria transformar liberdade em libertinagem, em uma licença para os grevistas praticarem impunemente ações lesivas contra os bens de outrem sem que estes nada pudessem fazer ${ }^{241}$.

Segundo Giovanni Orlandini, outro autor italiano, ao por o direito de greve em um plano supraordinário em relação às demais fontes do direito positivo, ele retirou destas até mesmo a possibilidade de criar limites. Esta conclusão é considerada pelo referido autor coerente com o que é comumente sustentado em relação aos direitos de liberdade clássicos, cuja constitucionalização se traduz na adoção do princípio da taxatividade dos limites, o que significa que eles devem encontrar fundamento na mesma norma que os reconhecem ou em outras disposições do texto da própria constituição ${ }^{242}$. Estas conclusões mostram-se perfeitamente adequadas ao direito brasileiro onde a greve também consiste em direito reconhecido constitucionalmente e o mesmo preceito que o reconhece como tal se encarrega de evidenciar que ela apresenta limites. É a conclusão que se extrai das assertivas previstas nos parágrafos $1^{\circ}$ e $2^{\circ}$ do artigo $9^{\circ}$ da Carta Magna. Estes limites, contudo, consoante estabelece o próprio texto constitucional, somente podem estar relacionados com a garantia de atendimento aos serviços essenciais da comunidade e com a punição aos casos de abuso do direito de greve.

O autor italiano supramencionado propõe ainda a adoção para o direito de greve da solução hermeutica consistente na presunção da máxima expansão das normas

\footnotetext{
${ }^{240}$ Decisão proferida em 22 de outubro de 2008.

241 "Uno sciopero senza limitazioni significherebbe transformare la liberta in libertinaggio, il diritto di sciopero in licenza riconosciuto agli scioperanti di compiere impunemente azioni anche delittuose oltre che lesive di Beni purê meritevoli di tutela" (VACCA, Michele. Il diritto di sciopero e le sue limitazioni nelle organizzaioni e Nei paesi europei. Milano: Giuffrè Editore: 1983, p. 38).

${ }^{242}$ ORLANDINI, Giovanni. Sciopero e servizi pubblici essenciali nel processo d'integrazione europea: uno Studio di diritto comparato e comunitário. Torino: Giappichelli editore: 2003, p. 24.
} 
constitucionais, que excluiria a possibilidade de restrição ao exercício de um direito fundamental pela via interpretativa ${ }^{243}$. Mais adiante ele esclarece que esta solução hermenêutica não implica na conclusão de que o direito de greve seja um direito ilimitável e imune à regulamentação por lei, significando simplemente que ele deve ser colocado em condição de garantia e, por conseguinte, não deve receber tratamento distinto daquele dado aos demais direitos de liberdade. Significa assegurar que referido direito deverá ser balanceado com os demais valores constitucionais de igual dignidade, que, a partir de Kant, seriam os únicos a limitar as restrições a tal direito em um ordenamento democrático ${ }^{244}$.

Em outra passagem, destaca que o problema da atuação legislativa no sentido de restringir o direito de greve se põe nos termos de uma correta definição dos bens reclamados e de sua compabilidade com o direito de greve. Para ele, quando o constituinte não dita critérios de guia para a intervenção legislativa, não resta outra alternativa a não ser buscá-los em outras normas constitucionais que apresentem valores eventualmente conflitantes. Esta necessidade de balanceamento se apresenta sobretudo quando é necessário conciliar o direito de greve com outros direitos que encontram assento constitucional $^{245}$.

Sob esta perspectiva, a greve, até mesmo por consistir em fato gerador de várias conseqüências, necessita estar submetida a um controle legislativo, afim de que essas conseqüências tenham um tratamento no elenco geral e a fim de que não só os interesses individuais, como também os coletivos e os do próprio Poder Público, possam ser respeitados, acatados e defendidos ${ }^{246}$.

Para Giovanni Orlandini a constitucionalização do Estado social inseriu uma forma particular de configuração e de estrutura, em que os direitos sociais devem se sobrepor à liberdade econômica, afinal "I diritti sociali nascono infatti como correzioni ai disequilibri

\footnotetext{
243 A tale principio è consequenziale l'adozione del cânone ermeneutico della presunzione della massima espansione delle norme costituzionali, che esclude la possibilita di restringere l'ambito di esercizio di um diritto fondamentale, in nome di limiti dedotti in via interpretativa dalla supposta natura dello stesso. ORLANDINI, Giovanni. Sciopero e servizi pubblici essenciali nel processo d'integrazione europea: uno Studio di diritto comparato e comunitário. Torino: Giappichelli editore: 2003, p. 24.

${ }^{244}$ Idem, p. 28.

245 ORLANDINI, Giovanni. Sciopero e servizi pubblici essenciali nel processo d'integrazione europea: uno Studio di diritto comparato e comunitário. Torino: Giappichelli editore: 2003, p. 30.

${ }^{246}$ Ibidem.
} 
generati da tali liberta; la restrizione di queste ultime è coessenziale alla loro esistenza"247. Em sua opinião a relativização entre liberdade econômica e direitos sociais não se põe em termos de balanceamento, mas no sentido de subordinar o primeiro aos segundos, de forma que o exercício da greve seja compatibilizado com a busca do objetivo de igualdade substancial. E ao final conclui que "Se un bilanciamento si vuol parlare, si tratta comunque di um 'bilanciamento ineguale"" ${ }^{248}$. Estas assertivas fazem, por exemplo, com que não se possa utilizar o argumento das perdas econômicas provocadas pela greve para justificar sua restrição ou cessação.

Como observam Bueno Magano e Mallet, a interpretação sistemática da Constituição mostra que tal direito encontra-se sujeito às seguintes limitações: as que devem ser observadas quando o seu exercício envolver atividades essenciais; as correspondentes ao conceito de abusividade; as derivadas da competência da Justiça do Trabalho, incumbida de julgar todos os conflitos entre trabalhadores e empregadores, inclusive o mais intenso deles, que é a greve. Segundo aludidos autores, além das apontadas limitações explícitas, o direito de greve sujeitar-se-ia, ainda, a limitações implícitas de dois tipos: as de caráter imanente ou as resultantes da coalisão com outros direitos fundamentais. As do primeiro tipo diriam respeito à própria natureza do instituto, concebido como instrumento de realização de direitos sociais e, por isso, não utilizável como arma para a promoção de objetivos diversos, como, por exemplo, os de natureza política. As do segundo tipo derivariam do choque com outros direitos fundamentais como o direito ao trabalho e o direito de propriedade, confronto que acarreta o automático desvirtuamento do direito de greve. Haveria, por fim, de se considerar a expressa proibição de greve imposta a militares e paramilitares $\left(\$ 5^{\circ}\right.$, artigo 42$)$, bem como a sujeição da greve do servidor civil ao inteiro alvedrio do legislador ordinário, a quem atribuiu a prerrogativa de determinar o conteúdo respectivo (artigo 37, VIII) ${ }^{249}$.

\subsubsection{Limitação ao direito de greve relacionada com a essencialidade da atividade}

Magano e Mallet observam que a Lei n. 7.783/89 reduziu sensivelmente a relação das atividades essenciais comparativamente à legislação anterior, a saber, o Decreto-lei n.

\footnotetext{
${ }^{247}$ ORLANDINI, Giovanni. Op cit, p. 35.

${ }^{248}$ Ibidem.

${ }^{249}$ MAGANO, Octávio Bueno; MALLET, Estêvão. O direito do trabalho na constituição. Rio de Janeiro: Forense, 1993, p. 308/309.
} 
1.632/78. As atividades que deixaram de ser tidas como essenciais são a distribuição de gás; energia elétrica; petróleo e outros combustíveis; serviços de banco, salvo os de compensação bancária; serviços de comunicação, salvo os de telecomunicações; os de carga e descarga ${ }^{250}$.

Ainda assim, cabe analisar o critério utilizado pelo legislador infraconstitucional para definir serviços e atividades essenciais. Refletindo sobre a questão, Bento Herculano Duarte Neto registrou que o legislador procurou evitar os principais transtornos que podem advir para a população no caso da completa paralisação de determinados setores da economia. Teria ele, assim, efetuado a relação nexo versus causa e, tendo verificado quais seriam as necessidade primordiais da comunidade, elencou no artigo 10 da Lei 7.783/89 as atividades e serviços que, se inexistentes, a rigor levariam ao não atendimento de tais necessidades ${ }^{251}$.

O rol de atividades essenciais ${ }^{252}$ afigura-se, contudo, muito numeroso. A essencialidade de algumas das atividades lá enumeradas vem sendo questionada pela doutrina. Bento Herculano Duarte Neto, por exemplo, questiona, com acerto, se todos os âmbitos de telecomunicações constituem serviços verdadeiramente essenciais ${ }^{253}$. Em resposta é possível afirmar, por exemplo, que uma interrupção no sistema de televisão a cabo, embora possa ser interpretado como serviço de telecomunicação, não deveria ser considerada paralisação em atividade essencial. Ademais a inserção dos serviços de telecomunicações entre as atividades essenciais ocorreu no final dos anos 80, quando o Estado ainda detinha o monopólio do sistema de telefonia e, por essa razão, uma paralisação total neste serviço tornaria impossível a comunicação à longa distância. Hoje

\footnotetext{
${ }^{250}$ Idem, p. 311.

${ }^{251}$ DUARTE NETO, Bento Herculano. Direito de greve: aspectos genéricos e legislação brasileira. São Paulo: LTr, 1992,p. 142.

${ }^{252}$ Art. 10 (Lei 77.83/89 São considerados serviços ou atividades essenciais:

I - tratamento e abastecimento de água; produção e distribuição de energia elétrica, gás e combustíveis;

II - assistência médica e hospitalar;

III - distribuição e comercialização de medicamentos e alimentos;

IV - funerários;

$\mathrm{V}$ - transporte coletivo;

VI - captação e tratamento de esgoto e lixo;

VII - telecomunicações;

VIII - guarda, uso e controle de substâncias radioativas, equipamentos e materiais nucleares;

IX - processamento de dados ligados a serviços essenciais;

$\mathrm{X}$ - controle de tráfego aéreo;

XI - compensação bancária.

${ }^{253}$ Aludido autor, entretanto, questiona a ausência de outros serviços no rol dos essenciais, como a prestação jurisdicional e a educação (Ibidem).
} 
com a criação dos sistemas de telefonia móvel (celular) e a possibilidade de comunicação à longa distância, com som e imagem, através da internet, não se justifica a impossibilidade de paralisação integral nos serviços de telefonia fixa.

Além de numeroso, o rol do artigo 10 vem sendo interpretado ampliativamente. Transporte coletivo, por exemplo, expressão tradicionalmente vinculada ao transporte terrestre feito por bonde, ônibus e metrô ${ }^{254}$ vem, hodiernamente sendo interpretada de forma a compreender também o transporte aéreo. Esta conclusão é questionável na medida em que fosse inexistente o transporte aéreo regular, o que de fato era até princípio do século XX, o serviço ainda assim seria atendido pela via terrestre. Causaria maior transtorno, maior demora, mas seria atendido, o que retira o seu caráter de essencialidade.

Outra crítica a ser feita ao rol do artigo 10 da Lei 7.783/89 é o de que ele utiliza algumas expressões excessivamente vagas como "processamento de dados ligados a serviços essenciais". Ora, a maioria dos serviços que recebem este nome é especializada na prestação deste serviço hoje chamado de tecnologia da informação e tem como clientes empresas maiores, entre elas as que se dedicam às chamadas atividades essenciais. Será que todas essas empresas chamadas de terceirizadas exercem atividade essencial? A resposta é necessariamente negativa. Não parece razoável concluir que a atividade de uma empresa responsável pelo processamento dos dados para cobrança de faturas e renovação de assinaturas deva ser considerada essencial e, por essa razão, impossibilitada de paralisar totalmente.

Cabe ressaltar, por fim, ainda em acentuada crítica ao rol do artigo 10 da Lei 7.783/89, que não obstante a legislação tenha registrado um acentuado avanço ao considerar essencial apenas a compensação bancária e não qualquer atividade bancária, é forçoso reconhecer que hoje talvez nem ela fizesse jus a esta classificação. Trata-se, é bem verdade, de uma atividade hoje bastante automatizada que conta com número de trabalhadores bastante reduzido em relação ao padrão historicamente registrado. Em uma categoria em que uma paralisação de todos os trabalhadores não impediria a prestação integral dos serviços, haja vista o alto nível de informatização do setor, com ampla possibilidade de se efetuar pagamentos, transferências, investimentos, resgates, pela

${ }^{254}$ Corroborando essa conclusão, o dicionário Houaiss da língua portuguesa define coletivo como veículo para transporte coletivo, exemplificando a relação mencionando ônibus e bonde (HOUAISS, Antônio; VILLAR, Mauro de Salles; FRANCO, Francisco Manoel de Mello. Dicionário Houaiss da língua portuguesa. Rio de Janeiro: Editora objetiva, 2009, p. 493). 
internet, em tempo real, sem precisar de trabalhadores para isso, continuar a considerar a compensação bancária uma atividade essencial é um grande despropósito. Esse exemplo evidencia que a relação de atividades essenciais da legislação brasileira está também obsoleta.

Na França as autoridades públicas utilizam o instituto da requisição (réquisition) para obter uma ordem judicial determinando a prestação de serviços dos trabalhadores. Este instituto, definido por Arnaud Martinon, Fabienne Leconte e Isabelle Taraud como “demande faite par l'autorité pour avoir à sa disposition des hommes ou des choses", vem se mostrando bastante controvertido. Quando a sua utilização objetiva evitar um desastre, o provimento obtém, em geral, a simpatia pública. Quando, diferentemente, ele é utilizado no curso de um conflito coletivo, como medida política, a polêmica se instala. Analisando a sua utilização, a doutrina francesa apresenta concepções diferentes. Alguns, como Arnaud Martinon, defendem a requisição. Outros, como Fabienne Leconte e Isabelle Taraud, criticam o que consideram utilização política de uma arma desleal. Para elas "la réquisition afronte d'emblée des libertés fondamentales et atteint des textes à fortes valeurs juridiques et symbolique: atteinte à l'interdiction du travail force ou à la liberte du travail...”. Quando utilizada no contexto de um movimento coletivo, a requisição "neutralise la volonté de cesser le travail"255.

No Brasil, a legislação não proíbe a greve nas atividades essenciais. O artigo 11 da Lei 7.783/89, apenas estabelece que "os sindicatos, os empregadores e os trabalhadores ficam obrigados, de comum acordo, a garantir, durante a greve, a prestação dos serviços indispensáveis ao atendimento das necessidades inadiáveis da comunidade"(caput), assim entendidas "aquelas que, não atendidas, coloquem em perigo iminente a sobrevivência, a saúde ou a segurança da população"(parágrafo único). Magano e Mallet enfatizam a intensidade do indigitado preceito legal ressaltando que, "no caso de sua inobservância,

\footnotetext{
255 MARTINON, Arnaud; LECONTE, Fabienne; TARAUD, Isabelle. Réquisitionner? Revue de droit du travail, Editions Dalloz, 2011, p. 9. No Brasil também há uma figura denominada requisição, disciplinada pelo Decreto 4.812/42, que dispõe sobre a requisição de bens imoveis e moveis, necessários às forças armadas e à defesa passiva da população, e dá outras providências. Essa figura, contudo, não é utilizada para interrupção de movimentos paredistas.
} 
transfere-se ao Poder Público a incumbência de assegurar a continuidade de tais serviços" $" 256$.

Esta responsabilidade subsidiária do Estado pela prestação dos serviços suscita uma interessante reflexão. Seria possível um provimento judicial impondo aos trabalhadores e ao sindicato o seu regular desempenho profissional nas atividades essenciais ou, diante do não atendimento dos serviços inadiáveis da comunidade, caberia ao Estado assumi-los, evitando assim prejuízos para a coletividade? Não obstante esta última alternativa afigurese mais consentânea com a literalidade do texto legal e com a valorização do direito de greve apregoada neste trabalho, percebe-se, na prática, a adoção da primeira solução, sobretudo em razão da falta de recursos estatais para a prestação dos aludidos serviços.

\subsubsection{Limitação ao direito de greve resultante de colisão com outros direitos fundamentais}

Diz um conhecido adágio jurídico que um direito se exercita com respeito a outros direitos $^{257}$. Partindo dessa premissa, Márcio André Medeiros Moraes observa que o direito de greve não é o único direito fundamental devendo, por conseguinte, ser exercido em harmonia com os demais direitos fundamentais ${ }^{258}$.

Giovanni Orlandini, observa que a greve, como todos os direitos fundamentais constitucionalmente garantidos, admite regulamentação apenas segundo o critério do menor sacrifício possível e não segundo aquele da excepcionalidade de seu exercício ${ }^{259}$.

Vitor Manoel Castan, destaca com razão, que “o caput do artigo $5^{\circ}$ da Constituição Federal, assegura o direito à vida, à liberdade, à segurança e à propriedade. O inciso XXII do artigo $5^{\circ}$ da Carta Magna também determina o direito de propriedade, portanto, o direito de greve encontra limites em confronto com outras regras" ${ }^{, 260}$.

\footnotetext{
${ }^{256}$ MAGANO, Octávio Bueno; MALLET, Estêvão. O direito do trabalho na constituição. Rio de Janeiro: Forense, 1993, p. 308/309.

${ }^{257}$ GARCIA, Paulo. Direito de greve. Rio de janeiro: Edições Trabalhistas, 1961, p 151.

258 MORAES, Márcio André Medeiros. A responsabilidade civil do sindicato perante o consumidor. 2001. 377 f. Tese (doutorado em Direito das Relações Sociais - Direito Civil). Pontíficia Universidade Católica de São Paulo, São Paulo, 2001, p. 3/4.

${ }^{259}$ ORLANDINI, Giovanni. Sciopero e servizi pubblici essenciali nel processo d'integrazione europea: uno Studio di diritto comparato e comunitário. Torino: Giappichelli editore: 2003, p. 33.

${ }^{260}$ CASTAN, Vitor Manoel. Abuso de direito sindical. São Paulo: LTr, 2009, p. 120.
} 
Bernard Teyssié destaca que a construção pretoriana do direito de greve pelo conselho constitucional francês aporta uma importante contribuição na medida em que registra que este direito deve ser conciliado com outros princípios de valor constitucional como a continuidade dos serviços públicos e a proteção da saúde da segurança de pessoas e bens. A necessidade desta conciliação pode conduzir à admissão da validade de certas restrições unilateralmente aportadas pelo empregador ao exercício do direito de greve, por exemplo, pela imposição da presença de trabalhadores em um internato que acolhia crianças vítimas de problemas de comportamento, um serviço de segurança pública ${ }^{261}$.

No Brasil, a necessidade de harmonização entre o direito de greve e o direito de propriedade restou enfatizada na decisão proferida pelo Corregedor Geral da Justiça do Trabalho, Min. Carlos Alberto Reis de Paula, nos autos da correição parcial tombada com o número TST-CorPar-59342-68.2010.5.00.0000, ajuizada contra a decisão proferida pelo Exmo. Juiz do Tribunal Regional do Trabalho da $9^{\text {a }}$ Região, Dr. Dirceu Pinto Júnior, nos autos do Mandado de Segurança nº-00682-2010-909-09-00.2:

Considerando-se, pois, que a própria decisão impugnada reconhece que o interdito proibitório é a medida correta para que o Banco busque evitar iminente turbação ou esbulho, e que o despacho que concedeu a liminar no interdito proibitório se firmou em provas carreadas aos autos, pelas quais não estaria havendo a necessária ponderação de interesses das garantias suscitadas - de um lado o direito de propriedade e ao livre trânsito, e de outro o direito de greve, defiro a liminar para suspender a eficácia da decisão proferida no Mandado de Segurança no 00682-2010-909-0900.2 , que deferiu a liminar para cassar a ordem de expedição de mandado proibitório, até o julgamento do Agravo Regimental.

A greve, como suspensão coletiva, temporária e pacífica, total ou parcial, da prestação pessoal de serviços a empregador (art. $2^{\circ}$ da Lei 7.783/89), naturalmente acarreta

\footnotetext{
${ }^{261}$ A la construction prétorienne du droit de la greve le Conseil constitutionnel apporte une importante contribution lorsqu'il souligne que ce droit doit être concilie avec d'autres "príncipes de valeur constitutionnelle" tels que la continuité du servisse public (Cons. Const., 25 juill. 1979: D. 1980, jurispr.. p. 101, note M. Paillet) ou la protection de la santé et de la secutiré des personnes et des biens (Cons. Const., 22 juill. 1980: Dr soc. 1980, p. 452, obs. D. Turpin). La necessite de cette conciliation peut conduire à admettre la validité de certaines restrictions unilatéralement apportées par l'employeur à l'exercice du droit de greve, par exemple em imposant la présence, dans um internat accueillant des enfants victimes de troubles du comportement, d'un servisse de sécurité (Cass. Soc., ler juill. 1985: JCP G 1985, IV, 317, qui se borne à demander aux juges du fond de vérifier si l'employer n'a pas limite abusivement le droit de greve en imposant un servisse de sécurité d'une importance excessive). A fortiori justifie-t-elle les mínima d'activité parfois fixés, au nom de la continuité du servisse public ou pour des raisons de sécutiré. (TEYSSIÉ, Bernard. Grève dans le secteur privé. Jurisclasseur Travail Traité, fasc. 70-10, 15 avril 2010)
} 
perda pecuniária para o empregador. Não fosse assim, o seu poder de pressão e sua eficácia seriam mínimos. Como evidencia Paulo Garcia, é um erro afirmar que ao fazer greve o operariado tenha como finalidade prejudicar a produção capitalista. O que o grevista deseja é que não seja ele o sacrificado ${ }^{262}$.

É preciso ter em mente, contudo, que o prejuízo causado pela greve não pode ser fruto de atos dolosos dirigidos contra o patrimônio da empresa. Neste sentido é o magistério de Raimundo Simão de Melo:

É claro que a greve existe para causar prejuízo, sem o qual, é um remédio inócuo. Esse prejuízo, entretanto, é aquele que decorre da suspensão da produção em razão da greve. Porém, se atingidos equipamentos, maquinários e outros bens, por atos outros que não o exercício regular do direito de greve, os responsáveis deverão arcar com os prejuízos decorrente, ante o princípio de que aquele que causa dano a outrem deve ressarci-lo das perdas (CC, 1rt. 186 e 927 e Lei n. 7.783/89, art. 15), pois a greve é um importante direito, que deve, todavia, ser exercido sob o pálio da responsabilidade ${ }^{263}$.

Sensível à necessidade de proteger o patrimônio das pessoas, a legislação penal brasileira tipifica o crime de paralisação de trabalho, seguida de violência ou perturbação da ordem, para cominar abstratamente a pena de 1 (um) mês a 1 (um) ano para quem "participar de suspensão ou abandono coletivo de trabalho, praticando violência contra pessoa ou contra coisa" (artigo 200 do Código Penal). Sob a rubrica de invasão de estabelecimento industrial, comercial ou agrícola, sabotagem, o legislador cominou pena de reclusão de 1 (um) a 3 (três) anos, e multa, para quem "invadir ou ocupar estabelecimento industrial, comercial ou agrícola, com o intuito de impedir ou embaraçar o curso normal do trabalho, ou com o mesmo fim danificar o estabelecimento ou as coisas nele existentes ou delas dispor" (art. 203 do Código Penal). Nos dois tipos penais o legislador demonstra sua preocupação com o patrimônio do empregador.

Fora do âmbito penal, a legislação trabalhista também cuidou de assegurar a preservação do patrimônio do empregador no curso do movimento paredista. Assegura o art. $9^{\circ}$, da Lei 7.783/89, a manutenção de equipes de empregados com o propósito de assegurar os serviços cuja paralisação resultem em prejuízo irreparável, pela deterioração

\footnotetext{
${ }^{262}$ Op cit, p. 10.

${ }^{263}$ MELO, Raimundo Simão de. A greve no direito brasileiro. São Paulo: LTr, 2006, p. 81.
} 
irreversível de bens, máquinas e equipamentos, bem como a manutenção daqueles essenciais à retomada das atividades da empresa, quando da cessação do movimento. $\mathrm{O}$ art. $6^{\circ}, \S 3^{\circ}$ da referida lei dispõe que "as manifestações e atos de persuasão utilizados pelos grevistas não poderão impedir o acesso ao trabalho nem causar ameaça ou dano à propriedade ou pessoa".

Como se vê, a lei não se preocupa apenas com os atos que efetivamente causem dano à propriedade do empregador, mas também com aqueles que representem uma ameaça de dano. Esta previsão abre margem para ações preventivas visando evitar que danos sejam praticados ao patrimônio do empregador. Estas ações, contudo, conferem ao julgador a difícil missão de tutelar a propriedade do empregador sem, contudo, violar o direito de greve impondo limitações que façam arrefecer o movimento ou torná-lo inócuo.

Paulo Garcia pondera que todos sabem e reconhecem que no decorrer de uma greve podem surgir atos delituosos que merecem punição, devendo a primeira providência do legislador ser no sentido de punir toda e qualquer violência contra pessoas e coisas. Após ponderar que não se pode conceber que atos atentatórios à liberdade individual e ao direito de propriedade fiquem impunes, Paulo Garcia destaca que " a lei penal comum é bastante para regulamentar a hipótese" e que "a punição não deve ser excessiva"264.

Dilema semelhante é vivenciado no momento de apreciar ações nas quais se busca uma intervenção preventiva para assegurar o acesso dos não-grevistas ao posto de trabalho, na medida em que a opção destes por trabalhar precisa ser harmonizada com o direito dos manifestantes de se organizar para pressionar o empregador. Como salienta Waldeck Rousseau “O direito de um só homem para trabalhar é tão respeitável como o direito de dez mil de irem à greve"265. No mesmo sentido Paulo Garcia destaca que "se o grevista pode fazer greve porque ele é um ser livre, podendo trabalhar ou deixar de trabalhar, logicamente, em seguimento ao mesmo raciocínio, ter-se-á que reconhecer ao operário o direito de trabalhar" 266 .

Após ressaltar que o fundamento da greve seria a liberdade de trabalho, Amauri Mascaro Nascimento destaca que "assim como individualmente ninguém pode ser

\footnotetext{
${ }^{264}$ GARCIA PAULO. Direito de greve. Rio de Janeiro: Edições trabalhista, 1961, p. 162.

${ }^{265}$ Apud GARCIA, Paulo. Direito de greve. Rio de janeiro: Edições Trabalhistas, 1961, p 103.

${ }^{266}$ GARCIA, Paulo. Direito de greve. Rio de janeiro: Edições Trabalhistas, 1961, p 103.
} 
obrigado a trabalhar para outrem, coletivamente o trabalhador também não pode ser coagido a prestar serviços contra a sua vontade". Observa ainda, com toda razão, que a liberdade de trabalho é um valor que se afirmou após a proscrição do trabalho escravo, de tal modo que, hoje, não mais são aceitas formas de constrangimento para a obtenção do trabalho humano. E que se a greve é simplesmente a recusa de trabalhar sob condições consideradas insatisfatórias, não encontraria espaço no atual contexto de ideias a afirmação de que os trabalhadores estariam obrigados à prestação de um trabalho que não mais consideram contraprestativo ${ }^{267}$.

Na doutrina estrangeira, Michele Vacca destaca que a consciência social não permite que no campo dos direitos trabalhistas os direitos sejam buscado por meios delituosos que impliquem na violação do direito de outrem de não participar da greve, pondera que esta violação "costituisce un plus rispetto al suo legittimo e naturale esercizio e, come tale, imponga la perseguibilità in vista degli interessi generali della colletività preminente su quelli economici dei prestatori di lavoro" 268 .

O mesmo autor enfatiza ainda que o direito de greve encontra o seu limite mais premente na antitética liberdade dos trabalhadores que não aderiram ao movimento. Em sua opinião o direito, ou mais propriamente, segundo seu entendimento, a liberdade de fazer a greve, não pode prejudicar a liberdade daqueles que não querem aderir à greve. Sob esta perspectiva, se por um lado a propaganda e outras formas de aliciamento e persuação para participar da greve, consideradas ações subsidiárias dos manifestantes, são meios legitimos enquanto não afetem outros direitos, a não participação não pode ser entendida como uma provocação putativa aos participantes, nem tampouco considerada um fato injusto. $^{269}$.

Dito isso, há que se exaltar o cuidado que deve ter o legislador ao elaborar regras que limitem o direito de greve para, com isso, proteger outro direito fundamental, e também a cautela que deve ter o julgador ao se deparar com um caso concreto em que se vislumbre uma colisão entre o direito de greve e outro direito fundamental, como o direito

\footnotetext{
267 NASCIMENTO, Amauri Mascaro. Direito do trabalho na Constituição de 1988. $2^{\mathrm{a}}$ edição. São Paulo: Saraiva, 1991, p.295.

${ }^{268}$ VACCA, Michele. Il diritto di sciopero e le sue limitazioni nelle organizzaioni e Nei paesi europei. Milano: Giuffrè Editore: 1983, p. 38.

269 VACCA, Michele. Il diritto di sciopero e le sue limitazioni nelle organizzaioni e Nei paesi europei. Milano: Giuffrè Editore: 1983, p. 39.
} 
de propriedade ou o direito dos trabalhadores não-grevistas ao trabalho. É o que destaca Paulo Garcia:

$\mathrm{Na}$ vida social, o direito da coletividade sobrepuja o direito do indivíduo. Esta é a grande verdade que se tornou o dilema do Estado Moderno. O direito individual é sagrado e deve ser respeitado. Mas o exercício desse direito não é absoluto. Tem que ceder diante do direito maior, que é o da coletividade, uma vez que o indivíduo só pode gozar direitos e vantagens enquanto a coletividade os assegura. O Estado não deve ter interesses particulares e não deve proteger esse ou aquele grupo de pessoas ou interesses. Protege um só interesse, que é o seu e com isto assegura aos indivíduos o exercício de seus direitos ${ }^{270}$.

É justamente neste paradoxo que reside uma das maiores complexidades do direito de greve. Se o Estado não deve ter interesses particulares nem proteger esse ou aquele grupo de pessoas ou interesses, não deve favorecer consumidores e empreendedores em detrimento dos trabalhadores. Deve assegurar aos indivíduos o exercício de seus direitos o que, em se tratando de direitos coletivos do trabalho, corresponde a viabilizar o exercício do direito de greve.

Razão assiste quanto a este ponto a Oscar Ermida Uriarte, que, a título de sugestão para as iniciativas legislativas de limitação ao direito de greve, destaca a necessidade de precisão e consenso na definição dos serviços essenciais, evitando assim que o direito de greve sofra limitações que excedam o absolutamente inevitável e, em segundo lugar, que o regime excepcional ao qual poderia submeter a solução dos conflitos nestas atividades também deveria ser acordado entre as partes. Como terceira proposta de conclusão, afirma a necessidade de que toda proibição ou limitação da greve nos serviços essenciais seja compensada por mecanismos equitativos, ágeis, participativos e eficazes de atenção e solução das reclamações dos trabalhadores. O autor uruguaio fala ainda na importância da prevenção deste tipo de conflito, a qual depende, fundamentalmente, de condições econômico-políticas, por uma parte, e, pela outra, de um fluido funcionamento de todo o sistema de relações de trabalho, a cujos efeitos as fórmulas consensuais parecem se revelar mais eficazes $^{271}$.

${ }^{270}$ GARCIA, Paulo. Direito de greve. Rio de Janeiro: Edições trabalhistas s.a, 1961, p. 112.

${ }^{271}$ ERMIDA URIARTE, Oscar. Apuntes sobre la huelga. $2^{\mathrm{a}}$ ed. Fundación de cultura universitária. Montevideo: 1996, p. 179. 
O grande problema para que esta solução negociada e consensual seja posta em prática é que, como bem observou Antonio Rodrigues de Freitas Júnior, “A legendária inclinação sociológica do Direito do Trabalho foi progressivamente perdendo terreno, no plano epistemológico, para a vocação formalista evidenciada no apego à abordagem normativista" 272 .

Ainda assim, o legislador brasileiro primou pela solução consensual ao, no artigo $7^{\circ}$ da Lei 7783/89, dispor que "a participação em greve suspende o contrato de trabalho, devendo as relações obrigacionais, durante o período, ser regidas pelo acordo, convenção, laudo arbitral ou decisão da Justiça do Trabalho".

Também o artigo $9^{\circ}$ sinalizou com uma solução consensual ao estatuir que o sindicato ou a comissão de negociação acordarão com a entidade patronal ou diretamente com o empregador as condições para que equipes de empregados com o propósito de assegurar os serviços cuja paralisação resultem em prejuízo irreparável, pela deterioração irreversível de bens, máquinas e equipamentos, bem como a manutenção daqueles essenciais à retomada das atividades da empresa quando da cessação do movimento. Com o escopo de estimular esse acordo, o legislador assegurou ao empregador, enquanto perdurar a greve, o direito de contratar diretamente os aludidos serviços necessários. Não é demais observar que a contratação deverá, nesse caso, ser mínima, apenas para assegurar os serviços cuja paralisação possa causar deterioração irreversível de bens, máquinas e equipamentos e a manutenção daqueles essenciais à retomada das atividades da empresa quando da cessação do movimento.

\subsubsection{Balizamento entre o direito de greve e outros direitos fundamentais}

Mario Rusciano destaca a importância do balizamento entre o direito de greve e os direitos fundamentais na análise da validade dos movimentos paredistas. Em sua opinião é possível afirmar que somente por meio do balizamento e da ponderação de valores é que o direito de greve, enquanto situação jurídica regulada, projeção de uma determinada

272 FREITAS JÚNIOR, Antonio Rodrigues de. Sindicato: domesticação e ruptura: um estudo da representação sindical no direito brasileiro. São Paulo: Ordem dos Advogados do Brasil, Departamento Editorial, 1989, p. 24/25. Em suas reflexões, referido autor destaca ainda que "Esta tendência fica tanto mais evidente quanto se constate que a formação do jurista, voltado para as preocupações do poder, foi cedendo lugar a uma outra de caráter conceitual e supostamente desinteressada" (Ibidem). 
situação social, se preenche progressivamente e adquire a nítida fisionomia de direito subjetivo $^{273}$.

Essa, entretanto, não é uma tarefa das mais fáceis. A greve, como já salientado, não é apenas um meio de autotutela dos trabalhos, ela é, em si mesma, um conflito. Nesta condição, é natural que o movimento entre em confronto com diversos outros direitos fundamentais. E a tendência sempre é tutelar os direitos afetados pelos manifestantes grevistas, sobretudo os dos terceiros alheios à relação de emprego, enfraquecendo o seu movimento. Os motivos são os mais diversos. Primeiramente há que se reconhecer que em termos quantitativos, uma greve no transporte coletivo, por exemplo, ou no sistema de abastecimento de água ou distribuição de remédios, afeta um número de pessoas muito maior do que o número de potenciais beneficiados pelo movimento. Isso já seria, por si só, um motivo para fazer o pêndulo balançar contra o direito de greve. Em termos qualitativos, falando-se em colisão entre o direito de ir e vir dos trabalhadores não-grevistas e o direito de greve, a tendência é sempre tutelar aquele em detrimento destes.

Mesmo quando se analisa o confronto sob a perspectiva do choque entre o direito de greve e direitos de propriedade do empregador, é compreensível, embora não adequado, que se tenha uma propensão a tutelar este em detrimento daquele. Parece ser essa a tendência natural quando se está diante de um movimento que causa prejuízo de milhões de reais por dia para se obter um reajuste salarial cuja diferença entre a pretensão dos trabalhadores e a última proposta feita pelo empregador é de apenas 0,5\%. A reivindicação, se separada do seu contexto fático-econômico, que pode ser de ausência de reajuste para os trabalhadores nos anos anteriores ou de inflação galopante no último ano, pode parecer absurda e a manifestação desnecessária, o que naturalmente atrairia simpatia para a tese contrária ao movimento.

Para se proteger direitos dos consumidores e dos usuários de serviços essenciais, que não tem culpa pela eclosão da greve, e mesmo para proteger o direito do empregador à posse e à integridade de seu patrimônio, tem sido comum intervenções, sobretudo por meio de decisões judiciais, que limitam o exercício do direito de greve.

\footnotetext{
${ }^{273}$ RUSCIANO, Mario. Diritto di sciopero e assetto costituzionale. Rivista italiana di diritto del lavoro, anno XXVIII, 2009, I, p. 57.
} 
Como bem destaca Virgílio Afonso da Silva, um modelo como o brasileiro que amplia a extensão do âmbito de proteção dos direitos fundamentais e, ao mesmo tempo, o conceito de intervenção estatal é um modelo que deve estar pronto para lidar com um problema decorrente dessa expansão: a colisão entre direitos e a necessária restrição deles em algumas situações ${ }^{274}$.

Dentro desta perspectiva de ampliação da proteção dos direitos fundamentais e do conceito de intervenção estatal e, em um ordenamento jurídico em que se consagrou o princípio da inafastabilidade de jurisdição, tem se tornado cada vez mais frequentes o recurso ao judiciário para obter proteção a bens e direitos supostamente ameaçados pelo direito de greve. Ronald Amorim e Souza observa que tem constituído prática recente o prévio ingresso, em juízo, por organizações patronais, de ações visando obter o interdito proibitório que veda o ingresso de trabalhadores grevistas em suas dependências, a difusão da greve em suas dependências ou cercanias e, o mais surpreendente, a utilização de carros dotados de equipamentos sonoros, na via pública, desde que nas proximidades dos estabelecimentos. Aduz ainda que o fundamento dessa ação é, ou seria, o receio de violência contra os equipamentos da empresa, suas instalações ou, in extremis, os clientes $^{275}$.

Analisando alguns dos interditos proibitórios que obtiveram o êxito total ou parcial para quem os ajuizou, é possível ressaltar ainda que além de proteção à posse mansa e pacífica do autor sobre os imóveis de sua propriedade, onde estão instalados os estabelecimentos, eles se fundamentam ainda na necessidade de se assegurar aos clientes o seu direito de ir e vir e aos trabalhadores não grevistas o seu direito ao trabalho. Nos autos do interdito proibitório tombado com o número 0001064-58.2010.5.05.0025, a $25^{\mathrm{a}}$ Vara do Trabalho de Salvador, concluiu, a partir de fotografias, que o Sindicato réu estava adotando a prática de lacrar a entrada das agências bancárias com faixas e cartazes, impedindo o acesso não só aos trabalhadores que não querem aderia ao movimento grevista, mas também a qualquer cidadão que pretendesse adentrar essas agências, o que feriria outra garantia fundamental: o direito de ir e vir, também previsto em sede constitucional (art. $5^{\circ}$, $\mathrm{XV})$.

\footnotetext{
${ }^{274}$ SILVA, Virgílio Afonso da. Direitos fundamentais: conteúdo essencial, restrições e eficácia. $2^{\mathrm{a}}$ edição. São Paulo: Malheiros,2010, p. 126.

${ }^{275}$ SOUZA, Ronald Amorim e. Greve \& Locaute. São Paulo: LTr, 2007, p. 181.
} 
Em um juízo de ponderação de valores, a 55 $5^{\text {a }}$ Vara do Trabalho de Salvador sobrepôs o direito de ir e vir dos não-grevistas e dos clientes do estabelecimento ao direito dos grevistas de fazer sua manifestação pacífica. É preciso, antes de mais nada, questionar se havia de fato violação ao direito de ir e vir, albergado no artigo $5^{\circ}, \mathrm{XV}$, que corresponde ao direito de locomoção, mais precisamente à liberdade de locomoção no território nacional e à liberdade de a pessoa entrar no território nacional, nele permanecer e dele sair com seus bens; e à liberdade de circulação.

A liberdade de locomoção no território nacional, que interessa ao presente estudo, corresponderia, segundo José Afonso da Silva, ao permissivo de que todos se locomovam livremente nas ruas, nas praças, nos lugares públicos, sem temor de serem privados de sua liberdade de locomoção. A liberdade de circulação, por sua vez, consistiria, segundo o mesmo constitucionalista "na faculdade de deslocar-se de um ponto a outro através de uma via pública ou afetada ao uso público". Afirma ainda, em remate, com respaldo em lição de Pedro Escribano Collado, que a Administração não poderá impedir, nem geral nem singularmente, o trânsito de pessoas de maneira estável, a menos que desafete a via ${ }^{276}$.

A partir desses ensinamentos, é possível constatar que o direito esculpido no artigo $5^{\circ}, \mathrm{XV}$, está relacionado com as vias públicas. Trata-se de uma liberdade dos cidadãos em face do Estado e não daquele em face de outro particular.

Pode-se argumentar, com todo acerto, que o direito de ir e vir de determinado particular pode ser cerceado por outro particular, por exemplo, em uma eventual hipótese de crime contra a liberdade como cárcere privado, sequestro, extorsão mediante sequestro. Além da perquirição de uma sanção penal, poder-se-ia, neste caso, ajuizar tutela jurisdicional reparatória fundamentada no dispositivo constitucional aludido, por aplicação da teoria da eficácia horizontal dos direitos fundamentais ${ }^{277}$.

É forçoso reconhecer, contudo, que não há violação nos casos em que os trabalhadores grevistas bloqueiam o acesso de clientes aos estabelecimentos de seu empregador. Referida conduta não lhes impede de circular livremente pelo território nacional, apenas lhes impede de ter acesso a um serviço. Não há, portanto, violação ao seu

${ }^{276}$ SILVA, José Afonso da. Comentário contextual à Constituição. São Paulo: Malheiros, 2005, p. 111.

$277 \mathrm{O}$ autor desta pesquisa mostrou-se favorável à teoria da eficácia horizontal dos direitos fundamentais, em particular à sua aplicação no direito do trabalho, em pesquisa anterior publicada com as seguintes referências: BOUCINHAS FILHO, Jorge Cavalcanti. Discriminação por sobrequalificação. São Paulo: LTr, 2009, p. $63 / 68$. 
direito de ir e vir, mas apenas um embaraço ao seu direito de, enquanto consumidor, ter acesso à prestação regular do serviço. Diz-se embaraço porque, a depender da situação, o cliente/consumidor poderá se dirigir a um outro estabelecimento e lá obter a prestação de serviços. A ponderação de valores neste caso parte de uma premissa equivocada.

No tocante aos não grevistas é possível sim que se esteja diante de uma violação ao seu direito ao trabalho. Se ele efetivamente deseja ter acesso à agência para trabalhar e é impedido pelos grevistas, caracterizada está a violação. O grande problema é que o judiciário, em expressivo número de casos, tem intervido, em juízo de cognição sumária e tutela preventiva, sem que exista prova da efetiva violação do direito ao trabalho. Como as aludidas ações são instruídas com prova documental e a liminar, eventualmente concedida, é prolatada antes da oitiva da outra parte, quando ainda não há prova de que trabalhadores foram impedidos de trabalhar. Esta situação acaba sendo presumida pelo julgador a partir de relatos e fotos. Ademais, analisar-se-á a própria regularidade deste obstáculo nos próximos itens ao se falar sobre a crise e reconstrução do direito de greve.

A tutela concedida para proteger a posse e a propriedade do empregador tampouco se justifica. O direito de greve, como já salientado, consiste justamente no direito de causar a outrem um prejuízo como forma de pressioná-lo a atender suas reivindicações. É evidente que o prejuízo a que se faz referência neste momento é o correspondente à paralisação das atividades, normalmente associado à ideia de lucros cessantes, não compreendendo a destruição do patrimônio do empregador. Para Mario Rusciano, no confronto entre direito de greve e direito de propriedade do empregador, o movimento será legítimo quando se limitar a causar dano à produção, vista como resultado dia a dia da atividade empresarial. Não o será, entretanto, quando afetar a produtividade da empresa como um todo, vale dizer a sua potencial capacidade de competir no mercado ${ }^{278}$. Mas para saber se houve prejuízo à produtividade e não apenas à produção é necessário que o movimento tenha sido deflagrado. Não é possível, através de uma tutela inibitória como a dos interditos proibitórios, concluir que a produtividade da empresa será afetada. Antes da

\footnotetext{
${ }^{278}$ Lo sciopero sarebbe lefittimo, quando <<si limita > - diciamo così - ad arrecare danno alla produzione, vista come risultato giorno per giorno dell'attività dell'azienda; non lo sarebbe, invece, quando dovesse compromettere la produttività dell'azienda stessa, vale a dire la sua potenziale capacità a stare utilmente sul mercato. In tale distinzione, mi pare di poter senz'altro individuare l'idea del contemperamento tra interesse dei lavoratori e interesse dell'impresa. RUSCIANO, Mario. Diritto di sciopero e assetto costituzionale. Rivista italiana di diritto del lavoro, anno XXVIII, 2009, I, p. 63.
} 
deflagração do movimento, qualquer conclusão a este respeito não passará de mera suposição.

Em outra decisão estudada durante a elaboração deste trabalho ${ }^{279}$, a $2^{\mathrm{a}}$ Vara do Trabalho de Lages -SC concedeu liminar determinando fosse garantido o livre acesso às agências de determinada instituição financeira sediada na cidade de Lages pelos seus clientes, usuários e empregados que não aderiram ou não pretendem aderir ao movimento grevista, ou seja, que desejem trabalhar, garantindo ainda a posse mansa e pacífica dos imóveis onde situam-se suas agências e estabelecimentos, devendo o sindicato se abster de efetuar manifestações no interior das agências de qualquer objeto ou pessoa que perturbe a ordem do interior das agências. Autorizou a utilização de força policial caso necessária, aplicando pena de multa diária de $\mathrm{R} \$ 15.000,00$ (quinze mil reais) até o limite de $\mathrm{R} \$$ 150.000,00 (cento e cinquenta mil reais). O fundamento da decisão foi de que a greve dos bancários estava sendo divulgada pela mídia e os documentos comprovavam que também foi deflagrada contra o impetrante.

Mas, será que o simples fato de haver uma greve ou, eventualmente, ameaça de greve, justifica a intervenção do judiciário para tutelar direitos supostamente colidentes com o direito de greve? A resposta para este questionamento é negativa. Como ressalta Ronaldo Lima dos Santos, "a simples ameaça de greve nada mais constitui do que o prenúncio do exercício de um direito, constitucionalmente consagrado, pelos trabalhadores"280. Não pode ela justificar uma medida liminar, proferida em juízo de cognição sumária, para estipular multas que inibem a ação dos grevistas.

Virgílio Afonso da Silva, em tese que lhe assegurou a cátedra de de Direito Constitucional e Direitos Fundamentais na Faculdade de Direito da Universidade de São Paulo $^{281}$, propõe, em apertada síntese, que para o balizamento de conflitos entre direitos fundamentais leve-se em conta que:

(1) O âmbito de proteção dos direitos fundamentais tem um suporte fático amplo, ou seja, devem ser interpretados da forma mais ampla possível, o que significa que qualquer ação, fato, estado ou posição jurídica que, isoladamente considerados, possam ser

\footnotetext{
${ }^{279}$ interdito proibitório tombado com o número 02546-2008-029-12-00-7

${ }^{280}$ SANTOS, Ronaldo Lima dos. Interditos proibitórios e direito fundamental de greve. Revista síntese trabalhista e previdenciária, n. 261, março 2011, p. 73.

${ }^{281}$ SILVA, Virgílio Afonso da. Direitos fundamentais: conteúdo essencial, restrições e eficácia. $2^{\mathrm{a}}$ edição. São Paulo: Malheiros,2010, p. 130.
} 
subsumidos ao "âmbito temático" de um direito fundamental devem ser considerados como por ele prima facie protegidos. Significa também que o conceito de intervenção estatal nos direitos fundamentais faz parte do suporte fático, por isso, deverá ser igualmente interpretado de forma ampla, o que implica na rejeição de teorias que defendem que meras regulamentações no âmbito dos direitos fundamentais não constituem restrições.

(2) Os direitos fundamentais não têm um conteúdo essencial definido a priori e de caráter absoluto.

(3) A diminuição da proteção não está na abertura das possibilidades de restrição, já que elas impõe um ônus argumentativo ao legislador e ao juiz, mas nas teorias que recorrem a figuras pouco claras como limites imanentes, conteúdos absolutos, especificidade, ou a outras formas de restrição ao suporte fático dos direitos fundamentais. Estas teorias liberam o legislador e o aplicador do direito de qualquer ônus argumentativo;

(4) A solução para a proteção dos direitos fundamentais estaria, destarte, na criação de diálogo intersubjetivo e de controle social da atividade do Legislador e do Judiciário, a partir de um modelo que impõe, a todo tempo, exigências de fundamentação.

Estas premissas mostram-se extremamante útil para um estudo acerca dos limites à ingerência das decisões judiciais nos movimentos paredistas. Embora conduza a inevitável conclusão de que o direito de greve pode ser restringido, quando em confronto com outros direitos fundamentais, ela enfatiza a necessidade de fundamentação para cada decisão judicial que enfrente o confronto entre o direito de greve e outros direitos fundamentais.

A partir da teoria externa dos direitos fundamentais que, diferentemente da teoria interna, que pressupõe a existência de apenas um objeto, o direito e seus limites (imanentes), divide esse objeto em dois, o direito em si, e, destacadas dele, as suas restrições, Virgílio Afonso da Silva entende possível se chegar ao sopesamento como forma de solução das colisões entre direitos fundamentais e, mais que isso, à regra da proporcionalidade, com suas três sub-regras - adequação, necessidade e proporcionalidade em sentido estrito ${ }^{282}$. Segundo esta teoria, o direito definitivo não é algo definido internamente e a priori. Somente nos casos concretos, após sopesamento, ou, se for o caso, aplicação da regra da proporcionalidade, seria possível definir o que definitivamente vale.

${ }^{282}$ SILVA, Virgílio Afonso da. Direitos fundamentais: conteúdo essencial, restrições e eficácia. $2^{\mathrm{a}}$ edição. São Paulo: Malheiros,2010, p. 138. 
O conteúdo definitivo do direito seria, portanto, obtido a partir de fora, a partir das condições fáticas e jurídicas existentes. Essa restrição a partir de fora, pode ser feita por meio de regras encontradas, sobretudo, na legislação infraconstitucional, que proíbem alguma conduta que é permitida prima facie por algum direito fundamental ou que autorizam alguma ação estatal cujo efeito é a restrição da proteção que um direito prima facie garantia, ou em princípios ${ }^{283}$. Nesta última hipótese caberá ao juiz, em cada caso concreto, decidir qual princípio deverá prevalecer. Quando isto ocorre há também uma restrição ao direito fundamental que é garantida pelo princípio que teve de ceder em favor do princípio considerado mais importante. Essa restrição, no entanto, não encontra fundamento em uma regra da legislação infraconstitucional, mas apenas na competência do juiz em tomar a decisão naquele caso concreto, sendo, portanto, baseadas em princípios e realizadas por meio de decisões judiciais ${ }^{284}$.

Também bastante útil ao estudo ora desenvolvido é o entendimento de Virgílio Afonso da Silva de que, sempre que estiver diante de colisão entre direitos fundamentais, a preferência deve sempre recair na medida menos gravosa. Em sua opinião, em sendo aceita esta tese, o Estado acabaria sendo omisso na grande maioria dos casos, pois, embora a omissão seja ineficiente para realizar objetivos que necessitem de uma ação estatal, ela será também, em geral, menos gravosa ${ }^{285}$. Em matéria de direito de greve essa conclusão é relevante na medida em que sendo a greve naturalmente a medida mais gravosa, fosse ela aceita, o direito de greve restaria inegavelmente enfraquecido e atingido.

O autor também questiona se a opção sempre pela medida mais eficiente não teria como conseqüência a inutilidade de se questionar o grau de restrição ao direito e o risco de toda medida ser reprovada no teste da necessidade, já que sempre seria possível imaginar medidas mais eficientes que a adotada, não importando o quanto ela restrinja direitos ${ }^{286}$. Em resposta a reflexão por ele mesmo proposta, aduz que o grau de restrição ao direito não é um critério inútil, porque, sempre que houver medidas tão eficientes quanto a determinada, esse será o critério decisivo. Além disso, no teste de necessidade não se deve perguntar se há medidas mais eficientes que a medida estatal adotada, mas apenas se há

\footnotetext{
${ }^{283}$ Ibidem, p. 140/141.

${ }^{284}$ Ibidem, p. 143.

${ }^{285}$ Ibidem, p. 173.

${ }^{286}$ SILVA, Virgílio Afonso da. Direitos fundamentais: conteúdo essencial, restrições e eficácia. $2^{\mathrm{a}}$ edição. São Paulo: Malheiros,2010, p. 173.
} 
medidas tão eficientes quanto, mas que restrinjam menos o direito afetado ${ }^{287}$. É correto, sob este aspecto, concluir que uma medida estatal que restrinja direito fundamental seja constitucionalmente justificável se, além de adequada para fomentar o objetivo que persegue, não houver medida alternativa que seja tão eficiente quanto e que restrinja menos o direito atingido ${ }^{288}$.

Virgílio Afonso da Silva destaca ainda que se fossem suficientes apenas os exames da adequação e da necessidade, uma medida que fomentasse um direito fundamental com grande eficiência, mas que restringisse outros vários direitos de forma muito intensa teria que ser considerada proporcional e, portanto, constitucional ${ }^{289}$. Daí a necessidade da última etapa da proporcionalidade, que consiste em um sopesamento entre os direitos envolvidos, com o escopo justamente de evitar que medidas estatais, embora adequadas e necessárias, restrinjam direitos fundamentais além daquilo que a realização do objetivo perseguido seja capaz de justificar ${ }^{290}$. Neste procedimento de sopesamento não se pode, entretanto, alcançar uma exatidão matemática, nem tampouco substituir uma argumentação jurídica por modelos matemáticos e geométricos. Quando muito, poder-se-ia construir modelos para servir de ilustração, mas mais importante que buscar fórmulas matemáticas seria a busca de regras de argumentação, critérios de valoração ou a fundamentação de precedências condicionadas $^{291}$.

Sob esta perspectiva e reconhecendo que o direito de greve, por sua própria natureza, entrará inevitavelmente em rota de colisão com outros direitos fundamentais, há que se reconhecer a utilidade de único modelo ilustrativo que parta da presunção de legitimidade e de validade do movimento grevista. Adotado este modelo, deve-se, em contrapartida, possibilitar a reparação de eventuais lesões desproporcionais a outros direitos fundamentais eventualmente constatadas no caso concreto. Essa reparação, entretanto, deverá ser feita a posteriori, como adiante se demonstrará, e em decisão bem fundamentada. A tutela preventiva, em se tratando de direito fundamental ameaçado em face de movimento grevista deve se limitar à garantia de atendimentos dos serviços inadiáveis da comunidade e a outras situações de excepcional gravidade verificadas em determinado caso concreto. A banalização da concessão de tutela preventiva para tutelar

\footnotetext{
${ }^{287}$ Ibidem, p. 174.

288 Ibidem.

${ }^{289}$ Ibidem.

${ }^{290}$ Ibidem.

${ }^{291}$ Ibidem, p. 176.
} 
direitos supostamente ameaçados pelo movimento grevista acaba por esvaziar o direito de greve de seu conteúdo e por retirar-lhe toda a sua importância enquanto direito fundamental.

\subsubsection{Limitação ào direito de greve baseada no motivo da deflagração}

Amauri Mascaro Nascimento, em seu estudo sobre a greve política, faz interessante referência ao movimento sindical revolucionário, que entende que a questão social não poderá encontrar solução a não ser com a modificação da estrutura política. Seria justamente esse pressuposto ideológico que animaria a ação política dos sindicatos com a amplitude do movimento político destinado a atacar as supostas causas impeditivas da melhoria da condição social do trabalhador, causas essas quer de ordem trabalhista, quer de ordem econômica e política $^{292}$.

Desse modo, a greve política direcionou-se como uma ação que não é dirigida contra o empregador, mas contra o Estado. O empregador não tem meios para atender os grevistas, porque nada dele é pedido. $\mathrm{O}$ maior argumento contrário à admissibilidade das greves políticas seria justamente o fato de eles não se traduzirem como formas de luta num conflito do trabalho. Não se trata, segundo Mascaro Nascimento, de um termo técnicojurídico cuja definição venha estabelecida pelo Direito, e tampouco tem um significado geralmente aceito nem entre os especialistas em ciência política, nem no uso popular. Não obstante, o mais importante é que, inclusive quando os conflitos, e em especial os conflitos trabalhistas, são declaradamente políticos, isso não significa que forçosamente não gozem de uma proteção legal, pois podem ter sido declarados por ocasião ou em apoio a um conflito de trabalho ainda que no fundo sejam políticos ${ }^{293}$.

Essa importante questão poria em evidência que há conflitos trabalhistas com um conteúdo político ou econômico que, em alguns momentos, não permitem delimitar as fronteiras que separam as diferentes esferas. Há protestos que são marcadamente políticos, como a reivindicação de eleições gerais. Há os que são econômicos ou de política econômica, como a manifestação contra a política do Fundo Monetário Internacional em

\footnotetext{
292 NASCIMENTO, Amauri Mascaro. Direito do trabalho na Constituição de 1988. $2^{\mathrm{a}}$ edição. São Paulo: Saraiva, 1991, p.300.

${ }^{293}$ NASCIMENTO, Amauri Mascaro. Direito do trabalho na Constituição de 1988. $2^{\text {a }}$ edição. São Paulo: Saraiva, 1991, p.300.
} 
relação aos países devedores. Há os que são econômicos e políticos ao mesmo tempo, como aqueles que se destinam a mostrar a oposição dos trabalhadores à política econômica do governo, dentro da qual está contida a política salarial que os afeta diretamente ${ }^{294}$.

Conquanto não admita as greves de caráter estritamente político por considerar que elas não se harmonizam aos princípios que regem a liberdade sindical ${ }^{295}$, o Comitê de Liberdade Sindical da Organização Internacional do Trabalho já afirmou textualmente que os interesses profissionais e econômicos que os trabalhadores defendem mediante o direito de greve abarcam não apenas a obtenção de melhores condições de trabalho ou reivindicações coletivas de ordem profissional, como também a busca de soluções para questões de política econômica e social e para os problemas que ocorrem nas empresas e que interessam diretamente aos trabalhadores ${ }^{296}$. Considerou, em outra oportunidade, que as organizações encarregadas de defender os interesses socioeconômicos e profissionais dos trabalhadores deveriam, em princípio, poder recorrer à greve para apoiar suas posições na busca de soluções para os problemas derivados de grandes questões de ordem política, econômica e social que tenham conseqüências imediatas para seus membros e para os trabalhadores em geral, especialmente em matéria de emprego, de proteção social e de nível de vida ${ }^{297}$.

\footnotetext{
294 Ibidem.

${ }^{295}$ Precedente 528 da $5^{\text {a }}$ edição da Recopilación de decisiones y princípios del Comité de Libertad Sindical del Consejo de Administración de la OIT que assim dispõe: "Las huelgas de carácter puramente político y las huelgas decididas sistemáticamente mucho tiempo antes de que las negociaciones se lleven a cabo no caen dentro del ámbito de los principios de libertad sindical". (Véase Recopilación de 1996, párrafo 481; 303.er informe, casos núm. 1810 y 1830. párrafo 61 y 329. ${ }^{\circ}$ informe, caso núm. 2094, párrafo 135.)

${ }^{296}$ Precedente 526 da $5^{\text {a }}$ edição da Recopilación de decisiones y princípios del Comité de Libertad Sindical del Consejo de Administración de la OIT que assim dispõe: "Los intereses profesionales y económicos que los trabajadores defienden mediante el derecho de huelga abarcan no sólo la obtención de mejores condiciones de trabajo o las reivindicaciones colectivas de orden profesional, sino que engloban también la búsqueda de soluciones a las cuestiones de política econômica y social y a los problemas que se plantean en la empresa y que interesan directamente a los trabajadores." (Véanse Recopilación de 1996, párrafo 479; $304 .^{\circ}$ informe, caso núm. 1851 , párrafo $280 ; 314 .^{\circ}$ informe, caso núm. 1787 , párrafo $31 ; 320 .^{\circ}$ informe, caso núm. 1865 , párrafo 526; 326. ${ }^{\circ}$ informe, caso núm. 2094, párrafo 491; 329. ${ }^{\circ}$ informe, caso núm. 2094, párrafo 135 y 331.er informe, casos núms. 1937 y 2027, párrafo 104.). No precedente 531, por sua vez, consignou-se que "El derecho de huelga no debería limitarse a los conflictos de trabajo susceptibles de fi nalizar en un convenio colectivo determinado: los trabajadores y sus organizaciones deben poder manifestar, en caso necesario en un âmbito más amplio, su posible descontento sobre cuestiones económicas y sociales que guarden relación con los intereses de sus miembros. (Véase Recopilación de 1996, párrafo 484; $300 .^{\circ}$ informe, caso núm. 1777, párrafo 71 y $320 .^{\circ}$ informe, caso núm. 1865, párrafo 526).

${ }^{297}$ Precedente 527 da $5^{\mathrm{a}}$ edição da Recopilación de decisiones y princípios del Comité de Libertad Sindical del Consejo de Administración de la OIT que assim dispõe: "Las organizaciones encargadas de defender los intereses socioeconômicos y profesionales de los trabajadores deberían en principio poder recurrir a la huelga para apoyar sus posiciones en la búsqueda de soluciones a los problemas derivados de las grandes cuestiones de política, económica y social que tienen consecuencias inmediatas para sus miembros y para los trabajadores en general,especialmente en materia de empleo, de protección social y de nivel de vida. (Véanse Recopilación de 1996 , párrafo $480 ; 305^{\circ}$ informe, caso núm. 1870 , párrafo $143 ; 320 .^{\circ}$ informe, caso núm.
} 
Em outro relevante precedente, o Comitê da OIT, após considerar que as greves de natureza puramente política não estão cobertas pelos princípios da liberdade sindical, os sindicatos deveriam poder organizar greves de protesto, em particular para exercer uma crítica contra a política econômica e social do governo ${ }^{298}$. Um exemplo particularmente digno de referência, pela dimensão e pela proximidade com a data de apresentação deste trabalho para qualificação, foi a greve geral organizada contra a reforma no sistema de aposentadorias proposta pelo Presidente Nicolas Sarkozy, na qual 3 milhões de pessoas protestaram, no dia 23 de setembro de 2010, em 239 cidades francesas, segundo números da Confédération générale du travail (CGT), contra o projeto apresentado pelo governo para reforma no sistema de aposentadoria, sendo aproximadamente 300000 delas na capital Paris que foi dividida em duas partes durante seis horas ${ }^{299}$.Não obstante alguns estudos contestem estatisticamente a afirmação globalmente repetida de que a greve faz parte da cultura da população francesa ${ }^{300}$, a importância que as greves de protesto têm na história da França é absolutamente incontestável.

Conquanto entenda que as greves de natureza puramente política não estão cobertas pelos princípios da liberdade sindical, como já visto, o Comitê da OIT consignou, no precedente $538^{301}$ da $5^{a}$ edição da Recopilación de decisiones y princípios del Comité de Libertad Sindical del Consejo de Administración de la OIT, que a proibição de toda greve

1865, párrafo 526, caso núm. 2027, párrafo 876; 336. informe, caso núm. 2354, párrafo 682 y $337 .^{\circ}$ informe, caso núm. 2323, párrafo 1039.)

${ }^{298}$ Precedente 529 da $5^{\text {a }}$ edição da Recopilación de decisiones y princípios del Comité de Libertad Sindical del Consejo de Administración de la OIT que assim dispõe: "Si bien las huelgas de naturaleza puramente política no están cubiertas por los principios de la libertad sindical, los sindicatos deberían poder organizar huelgas de protesta, en particular para ejercer una crítica contra la política económica y social del gobierno. Las organizaciones sindicales deberían tener la posibilidad de recurrir a huelgas de protesta, en particular con miras a ejercer una crítica con respecto a la política económica y social de los gobiernos. (Véanse Recopilación de 1996 , párrafo $482 ; 300 .^{\circ}$ informe, caso núm. 1777 , párrafo $71 ; 304 .^{\circ}$ informe, caso núm. 1851, párrafo 280, caso núm. 1863, párrafo 356; 314. ${ }^{\circ}$ informe, caso núm. 1787 , párrafo $31 ; 320 .^{\circ}$ informe, caso núm. 1865, párrafo 526 y 333.er informe, caso núm. 2251, párrafo 985.). Precedente 542 da $5^{\text {a }}$ edição da Recopilación de decisiones y princípios del Comité de Libertad Sindical del Consejo de Administración de la OIT que assim dispõe: “ La declaración de ilegalidad de una huelga nacional en protesta por las consecuencias sociales y laborales de la política económica del gobierno y su prohibición constituyen una grave violación de la libertad sindical.(Véase Recopilación de 1996, párrafo 493.)”

299 Informação disponível em <http://fr.wikipedia.org/wiki/Mouvement_social_en_France>. Acesso em 01/01/11.

300 ACRIMED (Action-critique-media. La France Pays des Grèves? Disponível em <http://www.acrimed.org/IMG/pdf/114Pays_des_greves.pdf >. Acesso em 01/01/11.

${ }^{301}$ Precedente 538 da $5^{a}$ edição da Recopilación de decisiones y princípios del Comité de Libertad Sindical del Consejo de Administración de la OIT que assim dispõe: "La prohibición de toda huelga no vinculada a un conflicto colectivo em el que sean parte los trabajadores o el sindicato, están en contradicción con los principios de la libertad sindical". (Véase Recopilación de 1996, párrafo 489 y 307. informe, caso núm. 1898, párrafo 325.) 
não vinculada a um conflito coletivo em que sejam parte os trabalhadores ou o sindicato está em contradição com os princípios por ela tutelados.

O Comitê de Liberdade Sindical também vem admitindo, sem ressalvas, as greves gerais quando realizadas como forma de protesto ${ }^{302}$. Em novembro de 2011 uma manifestação geral convocada pelas duas principais centrais sindicais de Portugal para protestar contra a política de cortes adotada pelo governo para reduzir a dívida e o déficit público do país ${ }^{303}$, provocou paralisações principalmente no setor de transporte público. Na capital Lisboa, não houve metrôs, trens e barcas no rio Tejo, e o serviço de ônibus manteve-se de forma bastante precária. Segundo dados dos sindicatos a greve teria contado com grande adesão, principalmente no setor público, em que mais de $90 \%$ dos funcionários paralisaram suas atividades. O governo discorda deste percentual afirmando que apenas $10,48 \%$ dos funcionários não trabalharam ${ }^{304}$.

Ainda sobre as greves gerais de cunho político, o Comitê consignou no precedente $534^{305}$ que a greve é um dos meios de ação de que devem poder dispor as organizações de trabalhadores e que é legítima e corresponde à esfera de atividade normal das organizações sindicais uma greve geral de 24 horas reivindicando o aumento dos salários mínimos, o respeito às convenções coletivas em vigor e modificações na política econômica.

\footnotetext{
${ }^{302}$ Precedente 543 da $5^{a}$ edição da Recopilación de decisiones y princípios del Comité de Libertad Sindical del Consejo de Administración de la OIT que assim dispõe: "En lo que respecta a la huelga general, el Comité ha considerado que la huelga es uno de los medios de acción del que deben poder disponer las organizaciones de trabajadores. Es legítima y corresponde a la esfera de actividad normal de las organizaciones sindicales una huelga general de 24 horas reivindicando el aumento de los salarios mínimos, el respeto de los convenios colectivos en vigor y el cambio de política econômica" (disminución de precios y del desempleo). (Véase Recopilación de 1996, párrafo 494.). Precedente 544 da $5^{a}$ edição da Recopilación de decisiones y princípios del Comité de Libertad Sindical del Consejo de Administración de la OIT que assim dispõe: "La convocatoria de una huelga general de protesta para que se ponga fin a los centenares de asesinatos de dirigentes sindicales y sindicalistas que se han producido en los últimos años constituye una acción sindical legítima por lo que su prohibición constituye una violación grave de la libertad sindical".(Véase Recopilación de 1996, párrafo 495.)

${ }^{303}$ Segundo noticiado no jornal Folha de São Paulo, Portugal chegou à beira de não pagar suas dívidas e teve que recorrer a empréstimo do FMI (Fundo monetário Internacional) e do Banco Central Europeu. Em troca de dinheiro se comprometeu a fazer mais cortes. O Parlamento discute agora o Orçamento para 2012. Na proposta, mais redução de salários e aumento nas horas trabalhadas. (MOREIRA, Patrícia de Melo. Greve afeta serviço público em Portugal: paralisação ocorreu em protesto contra os cortes propostos pelo governo como medida para tirar o país da crise. Folha de São Paulo, sexta-feira, 25 de novembro de 2011, p. A15).

${ }^{304}$ MOREIRA, Patrícia de Melo. Greve afeta serviço público em Portugal: paralisação ocorreu em protesta contra os cortes propostos pelo governo como medida para tirar o país da crise. Folha de São Paulo, sextafeira, 25 de novembro de 2011, $p$. A15.

${ }_{305}$ Precedente 534 da $5^{\mathrm{a}}$ edição da Recopilación de decisiones y princípios del Comité de Libertad Sindical del Consejo de Administración de la OIT que assim dispõe: "Una prohibición general de las huelgas de solidaridad podría ser abusiva y los trabajadores deberían poder recurrir a tales acciones a condición de que sea legal la huelga inicial que apoyen. (Véanse Recopilación de 1996, párrafo 486; 303.er casos núms. 1810 y 1830 , párrafo $61 ; 307 .^{\circ}$ informe, caso núm. 1898 , párrafo $325 ; 320 .^{\circ}$ informe, caso núm. 1963, párrafo 235 ; 333.er informe, caso núm. 2251, párrafo 985 y $338 .^{\circ}$ informe, caso núm. 2326, párrafo 445.)
} 
A Corte Costituzionale italiana, nas sentenzas n. 123 de 1962, n. 141 de 1967 e ns. 1 e 290 de 1974, reconheceu legitimidade às greves que não eram inerentes a reivindicações contratuais, mas organizadas em busca de reivindicação de bens próprios das disciplina constitucional das relações econômicas ${ }^{306}$. Ao assim decidir validou a greve com motivação político-econômica.

Analisando a legislação brasileira em vigor, Julpiano Chaves Cortez observa que o artigo $9^{\circ}$, caput da Constituição Federal e o artigo $1^{\circ}$, caput da Lei $7.783 / 89$, caso interpretados literalmente ou gramaticalmente, conduzem à conclusão de que o direito de greve é assegurado aos trabalhadores sem restrições, podendo ser usado tanto para a obtenção de melhoria das condições de trabalho (greves típicas), como para a conquista de interesses políticos, de apoio, de pressão, de solidariedade, de protesto, etc. (greves atípicas - interpretação ideológica). Ressalva, entretanto, que se o caput do aludido dispositivo infraconstitucional comporta uma interpretação ampliativa do direito de greve, o mesmo não pode ser dito em relação ao seu parágrafo único que o restringe ao dispor que o direito de greve será exercido na forma estabelecida nesta lei. Conclui observando que o entendimento predominante na doutrina e na jurisprudência é o de limitar o exercício do direito de greve às questões de interesses profissionais ou de fins contratuais e que possam ser atendidos pelos empregadores ${ }^{307}$.

O mesmo autor opina que nos termos da legislação vigente, o objetivo da greve é de caráter trabalhista, não alcançando aqueles alheios à categoria econômico-profissional, como ocorre com as greves de interesse político, de solidariedade e/ou de protesto, salvo se tiver em mira a defesa de algum interesse profissional ou alguma condição socioeconômica dos trabalhadores. E conclui que o movimento paredista não voltado para a defesa dos interesses trabalhista-profissionais (maiores salários e melhores condições de trabalho), deve ser considerado abusivo, conforme entendimento predominante na jurisprudência brasileira $^{308}$.

\footnotetext{
${ }^{306}$ GALANTINO, Luisa. Diritto sindacale. Torino: Giappichelli Editori, 2009, p. 204.

${ }^{307}$ CORTEZ, Julpiano Chaves. A lei de greve. São Paulo: LTr, 2010, p. 35.

${ }^{308}$ CORTEZ, Julpiano Chaves. A lei de greve. São Paulo: LTr, 2010, p. 35. A jurisprudência francesa também não reconhece a greve por motivos exclusivamente políticos, como evidencia a seguinte lição de Bernard Teyssié: "La faculté de faire greve est un droit accordé aux salariés pour la défense de leurs intérêts professionnels, non pour la promotion de leurs opinions politiques, ni, a fortiori, pour la défense d'intérêts quelconques. Un détournement (injustement nuisible au chef d'entreprise, la satisfaction des revendications présentées par les grévistes ne relevant pas de lui) peut être reproché à toute greve politique, y compris celles destinées à soutenir l'action gouvernementale" (Cpr. Cass. Soc., 19 juin 1963: D. 1963, jurispr.. p. 68, note
} 
Evidenciando a necessidade de motivação trabalhista para o direito de greve, a Seção de Dissídios coletivos do TST já decidiu que os Tribunais Trabalhistas devem analisar os movimentos grevistas sob duplo enfoque: o de sua motivação e o da adequação às exigências da Lei n. 7783/89, exatamente por constituir-se este num meio de pressão extrema, de autotutela, altamente lesivo à sociedade como um todo, pelo que não há falar em exercício absoluto e irrestrito do direito apenas por contar com previsão constitucional $^{309}$. A Seção de Dissídios Coletivos do Tribunal Regional do Trabalho da $2^{\mathrm{a}}$ Região, por sua vez, considerou uma greve dos metroviários materialmente abusiva por ter a paralisação dos serviços ocorrido por motivação política ${ }^{310}$.

Também entendendo pela impossibilidade da greve política, Ari Possidônio Beltran observa que nas greves de protesto contra o Estado, ainda que haja a participação do grupo, o objetivo imediato não se refere a interesses laborais da categoria e, por conseguinte, existe manifestação daquela coletividade no exercício de sua cidadania e não como grupo organizado postulando a respeito de interesses laborais. Em sua opinião, por faltar o requisito do elemento objetivo relacionado com o contrato de trabalho, a greve política não seria tecnicamente um conflito coletivo de trabalho. Ficaria, portanto, assegurado ao sujeito coletivo prejudicado, o caminho do dissídio somente em relação às conseqüências do ato, uma vez que o ordenamento não lhe propicia qualquer outra alternativa de lograr a ordem em sua atividade e assegurar o transporte público - uma necessidade básica da população e o objetivo econômico de seu empreendimento ${ }^{311}$.

G. Lyon-Caen; JCP G 1963, II, 13428, note H. Sinay; Dr. soc. 1964, p. 64, obs. J. Savatier - Rappr. CE, 20 juin 1947: Rec. CE 1947, p. 284 apud TEYSSIÉ, Bernard. Grève dans le secteur privé. Jurisclasseur Travail Traité, fasc. 70-10, 15 avril 2010) .

${ }^{309}$ Aos Tribunais Trabalhistas, no julgamento de dissídio de greve, impõe-se analisar o movimento sob duplo enfoque: o de sua motivação e o da adequação às exigências da Lei n. 7783/89, exatamente por constituir-se este num meio de pressão extrema, de autotutela, altamente lesivo à sociedade como um todo, pelo que não há falar em exercício absoluto e irrestrito do direito apenas por contar com previsão constitucional (TST RODC 384.225/97.0 - (Ac.SDC) - Rel. Min. Armando de Brito).

310 Atividade essencial - Greve dos metroviários - Abusividade material do movimento - O movimento de paralisação dos serviços qualificados no art. $9^{\circ}$ da Constituição Federal tem de estar vinculado à reivindicação contida no contrato de trabalho. Esta é a materialidade necessária, para que se possa falar em greve. Se a paralisação dos serviços ocorreu por motivação política, a greve, por mais justa que possa parecer, deve ser considerada materialmente abusiva. Por outro lado, o não atendimento à ordem judicial de manutenção mínima dos serviços configura também afronta ao sistema jurídico positivo, sustentáculo do Estado Democrático de Direito, impondo-se, por consequência, a aplicação da multa por descumprimento da liminar. Greve que se julga abusiva. (TRT 2 ${ }^{\mathrm{a}}$ Região - DC - 20258-2006-000-02-00-5 (Ac. 2007000529) Rel. Nelson Nazar - Publicação 2.4.2007)

${ }^{311}$ BELTRAN, Ari Possidônio. A autotutela nas relações de trabalho. São Paulo: LTr, 1996, p. 63. 
Raimundo Simão de Melo, por outro lado, afirma que o direito de greve previsto no artigo $9^{\circ}$ da Constituição Federal, embora não seja um direito absoluto e irrestrito, está assegurado de forma ampla aos trabalhadores para a defesa de seus interesses, quer trabalhistas stricto sensu, quer profissionais lato sensu, aqui considerados aqueles que constituem o chamado piso vital mínimo do cidadão, consagrados no art. $6^{\circ}$ da Constituição Federal. Entende, por conseguinte, que são admitidas as greves políticas e de solidariedade ou protesto, desde, porém que voltadas para a defesa de interesses trabalhista-profissionais ${ }^{312}$.

Opinião similar é defendida por Jorge Luiz Souto Maior, segundo quem a abrangência do direito de greve não se limitaria a reavaliação das normas contratuais estabelecidas, integrando também a lacuna, o vazio, ou seja, o que não fora fixado em cláusulas específicas, já que o vazio não é um nada e sim a ocupação de um lugar daquilo que lá poderia estar. $\mathrm{O}$ direito permitiria, portanto, aos trabalhadores defenderem, por meio da greve, os interesses que consideram relevantes para a melhoria da sua condição social e econômica até mesmo fora do contexto da esfera obrigacional com um empregador determinado $^{313}$.

Interessante é o entendimento adotado pela doutrina e pela jurisprudência italianas, que reconhecem o direito de manifestação política dos trabalhadores, mas não se lhes atribui o nome de greve. Com efeito, a Corte Costituzionale, na decisão n. 290 de 1974, asseverou existir liberdade de greve política no confronto do Estado, mas não direito de greve com finalidade exclusivamente política. Isso significa, na visão de Luisa Galantino, que a greve exclusivamente política é lícita sob o aspecto penal, mas ilícita sob o aspecto civilistico, podendo, por esta razão, dar lugar a sanções aplicáveis pelo empregador ${ }^{314}$.

Amauri Mascaro Nascimento afirma que tudo depende do direito positivo vigente em cada país, de modo que a greve política é ilegal onde e quando a norma jurídica, ou a jurisprudência dos tribunais a proibir ${ }^{315}$. Sob esse ângulo, no Brasil, a Lei n. 4.330, de 1964, a proibiu expressamente e a Lei 7.783/89 apenas silenciou. A greve política não é

\footnotetext{
${ }^{312}$ MELO, Raimundo Simão. A greve no direito brasileiro. São Paulo:LTr, 2006, p. 50.

${ }^{313}$ MAIOR, Jorge Luiz Souto. O direito de exercer o direito de greve. In: THOMÉ, Candy Florêncio e SCHWARZ, Rodrigo Garcia. Direito coletivo do trabalho: curso de revisão e atualização. Rio de Janeiro: Elsevier, 2010, p. 257.

${ }_{314}^{314}$ GALANTINO, Luisa. Diritto sindacale. Torino: Giappichelli Editori, 2009, p. 206.

${ }^{315}$ NASCIMENTO, Amauri Mascaro. Direito do trabalho na Constituição de 1988. $2^{\text {a }}$ edição. São Paulo: Saraiva, 1991, p.300/301.
} 
incompatível com os artigos $1^{\circ}$ da Lei 7.783/89, vez que ele apenas estatui ser assegurado o direito de greve, competindo aos trabalhadores decidir sobre a oportunidade de exercê-lo e sobre os interesses que devam por meio dele defender. O interesse a ser defendido em uma greve pode, perfeitamente, ser político. Basta, para tanto que assim decidam os trabalhadores. A oportunidade, por sua vez, pode, naturalmente, ser a proximidade de uma eleição, referendo ou outro acontecimento de cunho político.

Tampouco o artigo $2^{\circ}$ da Lei 7.783/89 exclui a possibilidade de organização de greves de cunho político. Ora a suspensão coletiva, temporária e pacífica, total ou parcial, de prestação pessoal de serviços a empregador pode visar pressionar o Poder Público, indiretamente atingido pelos efeitos do movimento paredista, e não o empregador. Não há, quanto a este ponto, obstáculo ao exercício do direito de greve.

Aponta-se, como obstáculo ao exercício do direito de greve política no Brasil, a exigência de frustração da negociação ou impossibilidade de recursos à via arbitral esculpida no artigo $3^{\circ}$ da Lei 7.783/89. É preciso reconhecer, contudo, que essa exigência não afasta a possibilidade de uma greve política no Brasil. Com efeito, nada impede de se fazer uma negociação envolvendo empregados, empregadores e governo, um pacto social $^{316}$, para deliberar sobre alguma questão política e, uma vez frustrada essa os representantes dos trabalhadores, provavelmente as Centrais Sindicais, mobilizarem uma greve de cunho político.

Bernard Teyssié enfatiza a dificuldade que é distinguir greves políticas e greves profissionais, haja vista que numerosos movimentos, em particular as greves gerais, apresentam caráter misto. São motivadas por questões profissionais e políticas. Cita precedente que após reconhecer que as greves mistas só se afiguram irregular na hipótese de a reivindicação profissional não ser mais que um pretexto para as reivindicações políticas $^{317}$ e precedente que considerou irregular movimento em que importava apenas a dimensão política ${ }^{318}$.

\footnotetext{
316 Acerca dos pactos sociais consultar FREITAS JÚNIOR, Antonio Rodrigues de. Conteúdo dos pactos sociais. São Paulo: LTr, 1993.

317 Cass. Soc., 4 mai 1956: D. 1956, jurispr.. p. 487 apud TEYSSIÉ, Bernard. Grève dans le secteur privé. Jurisclasseur Travail Traité, fasc. 70-10, 15 avril 2010.

${ }^{318}$ Cass. Soc., 10 mars 1961: Dr. soc. 1961, p. 363, obs. J. Savatier - Rappr. Cass. Soc., 3 mars 1956: JCP G 1956, II, 9552, où les juges avaient admis que le caractere professionnel "se trovait absorbé par le caractere politique". - Cass. soc., 29 mai 1979: D. 1980, inf. Rap. P. 23, obs. Ph. Langlois, où la chambre criminelle de la Cour de cassation semble adopter une solution moins rigoureuse et admettre qu'une greve est licite lorsque des revendications precises, d'ordre professionnel, sont présentées par les salariés, même si eles n'ont qu'un
} 
Após também comentar a dificuldade em qualificar uma greve como trabalhista ou política, ressaltando que uma interpretação teleológica levaria à conclusão de que sempre que a greve contiver uma reivindicação trabalhista, ainda que impregnada de um componente político, estar-se-ia diante de um conflito trabalhista em sentido lato, Amauri Mascaro Nascimento pondera que apenas haverá uma disputa trabalhista se as partes envolvidas forem os trabalhadores e o empregador, visto que se a pretensão não está no quadro dos atos que por este podem ser atendidos, não haverá disputa com o empregador, sendo inatingível o fim da greve $\mathrm{e}^{319}$.

A despeito destas dificuldades, há que se reconhecer a possibilidade de greve política no Brasil sempre que observados os requisitos da Lei 7.783/89 ou, consoante se demonstrará a seguir, quando mesmo sem a observância dos aludidos requisitos a greve não puder ser considerada abusiva por não causar prejuízo desproporcional, ou seja, que atinja a produtividade e não a produção, ao empregador.

Embora não admita a greve política, opinião da qual não se compartilha, Ari Beltran admite as greves de solidariedade, ou de simpatia, por entender que esta versará, ainda que de forma indireta, sobre interesses profissionais, no reforço de pressão sobre empregadores. Abusivo ou não, o movimento terá por objeto, em sentido amplo, interesses abstratos relacionados com o trabalho, configurando, pois, tecnicamente, conflito coletivo de trabalho ${ }^{320}$.

Comparando a Lei n. 4.330/64, com a atual Lei de Greve é possível concluir pela validade da greve de solidariedade no Brasil. Enquanto aquela proibiu expressamente a greve de solidariedade, esta silenciou quanto a este ponto. E a interpretação que mais se harmoniza com o texto constitucional é a de que esta lacuna decorre de uma opção legislativa e não de um descuido do legislador. Afinal, como bem observa Amauri Mascaro Nascimento, a Constitução Federal de 1988, ao conferir aos trabalhadores o poder de definir os interesses a serem defendidos através da greve - dentre os quais estaria incluído o apoio a outros trabalhadores -, desde que assim venha a ser pelos titulares do direito

caractere accessoire par comparaison avec les motivations politique du mouvement. - Cass. crim., 12 jan. 1971: D. 1971, jurispr.. p. 129. Ibidem.

${ }^{319}$ NASCIMENTO, Amauri Mascaro. Direito do trabalho na Constituição de 1988. 2a edição. São Paulo: Saraiva, 1991, p.301.

${ }^{320}$ BELTRAN, Ari Possidônio. A autotutela nas relações de trabalho. São Paulo: LTr, 1996, pp. 63/64. 
decidido, reconhece o direito de greve de forma ampla, sem restrições quanto à solidariedade ${ }^{321}$.

Segundo Bernard Teyssié, destinadas a apoiar uma reivindicação à qual os grevistas não são diretamente interessados, a greve de solidariedade requer um tratamento diferente, seja ela proclamada no seio de uma empresa, para a defesa dos interesses de certos de seus membros, ou de um entre eles, seja ela observada por solidariedade com trabalhadores de uma empresa estranha à primeira ${ }^{322}$.

Referido autor entende que a greve deflagrada no interior de uma empresa para a defesa de um ou alguns de seus trabalhadores é, a princípio, regular. Seria o caso da greve de solidariedade objetivando protestar contra a decisão de transferir determinados trabalhadores $^{323}$ ou que tenha por escopo a reintegração de um determinado trabalhador da empresa ${ }^{324}$ ou de muitos trabalhadores da empresa ${ }^{325}$ dispensa de empregados, sejam trabalhadores ordinários sejam representantes sindicais ${ }^{326}$.

Bernard Teyssié refere-se à precedente da jurisprudência francesa que não reconheceu como greve um movimento que tinha por único objetivo apoiar um trabalhador despedido em razão de faltas pessoais ${ }^{327}$.

\footnotetext{
${ }^{321}$ NASCIMENTO, Amauri Mascaro. Direito do trabalho na Constituição de 1988. 2a edição. São Paulo: Saraiva, 1991, p.299.

${ }^{322}$ TEYSSIÉ, Bernard. Grève dans le secteur privé. Jurisclasseur Travail Traité, fasc. 70-10, 15 avril 2010.

${ }^{323}$ Cass.soc., 21 juill. 1950: Dr. soc. 1952, p. 534 apud TEYSSIÉ, Bernard. Grève dans le secteur privé. Jurisclasseur Travail Traité, fasc. 70-10, 15 avril 2010.

${ }^{324}$ Cass. soc., 13 nov. 1954: Dr. soc. 1955, p. 163. - Cass. soc., 4 juiz 1969: D. 1969, jurispr.. p. 588. - Cass. crim., 22 oct. 1986: Dr. soc. 1988, p. 150, obs. J. Déprez apud TEYSSIÉ, Bernard. Grève dans le secteur privé. Jurisclasseur Travail Traité, fasc. 70-10, 15 avril 2010.

${ }_{325}$ Cass. soc., 27 nov. 1985: D. soc. 1988, p. 152, obs. J. Déprez. Ibidem.

${ }^{326}$ Cass. soc., 21 juill. 1951: Dr. soc. 1952, p. 117. - Cass. soc., 26 juin 1952: Dr. soc. 1952, p. 534. Rappr. Cass. crim., 27 nov. 1973: Dr. ouvrier 1974, p. 178, note N. Alvarez. - Cass. soc., 30 juin 1976: bull. Civ. 1976, V, n. 403. Ibidem.

${ }^{327}$ La régularité de la grève de solidarité ne cede-t-elle, toutefois, devant la reconnaissance du bien-fondé de la mesure prise par l'employeur? Il convient de l'admettre lorsque la mesure prise à l'encontre d'un salarié (et qui a suscite le mouvement de protestation) s'explique par des raison qui lui sont strictement personnelles: atitude agressive à l'égard de supérieurs hiérarchiques ou de cliente de l'entreprise, incompétence, etc. La qualification même de grève, au sens de l'article L. 2511-1 du Code du travail, est exclue: le mouvement qui a pour seul objet de soutenir un salarié licencie en raison de sa faute personnelle, "ne constitue pas l'exercice du droit de grève" (Cass.soc., 16 nov. 1993: Dr. soc. 1994, p. 35, rapp. Ph. Waquet, note J.-E. Ray; JCP E 1995, II, 658, note B. Siau). Dès lors, en revanche, que la décision prise par l'employeur sanctionne un comportement qui n'est pas étranger à des revendications professionnelles intéressant l'ensemble du personnel, la grève de solidarité demeure régulière en dépit du bien-fondé de la mesure (mutation, rétrogradation, licenciement...) arrêtée par la direction de l'entreprise (Cass. soc., 27 nov. 1985: Dr. soc. 1988, p. 152, obs. J. Déprez apud TEYSSIÉ, Bernard. Grève dans le secteur privé. Jurisclasseur Travail Traité, fasc. 70-10, 15 avril 2010).
} 
A jurisprudência francesa considera que uma paralisação de trabalho observada dentro de uma empresa por solidariedade com os trabalhadores de outra só será considerada regular se o seu escopo for apoiar um movimento lícito. Por aplicação do princípio de que o acessório segue a sorte do principal, consignou-se que uma greve de solidariedade que apoiar um movimento ilegal adquire o mesmo caráter ${ }^{328}$.

Na hipótese de o conflito principal se desenvolver dentro de condições que assegurem sua regularidade, é relevante apreciar a dimensão da ligação existente entre as reivindicações que são apresentadas e dos interesses dos trabalhadores associados ao movimento de apoio. Será regular a greve através da qual os trabalhadores de uma empresa se associem a um movimento de protesto que repouse sobre reivindicações que "pour être générales et communes à un très grand nombre de travailleurs, n'en étaient pas moins de nature à les intéresser" 329 . Deverá, por outro lado, ser considerada irregular a paralisação de trabalho decidida pelos empregados de uma empresa para apoiar reivindicações, objeto do conflito principal, que não sejam relevantes para os agentes do movimento ${ }^{330}$.

Deve-se equiparar a uma greve de solidariedade externa, e receber o mesmo tratamento, a situação na qual os empregados desligados de uma empresa se associem à uma greve desencadeada pelos empregados desta. A simples constatação de que referida greve é, dentro de seu princípio, lícita e se encontra apoiada em reivindicações que interessem a eles (como, por exemplo, a melhoria das condições de trabalho) assegura a regularidade da cessação de sua própria paralisação de atividade $^{331}$.

Quando uma paralisação de trabalho é observada dentro de uma empresa por solidariedade com os empregados de uma empresa distinta da anterior, a jurisprudência da

\footnotetext{
${ }^{328}$ Lorsqu'un arrêt de travail est observé dans une entreprise par solidarité avec les salariés d'une firme distincte de la precedente, la jurisprudence en exclut d'emblée la régularité s'il intervient à l'appui d'un mouvement illicite. Application du príncipe selon lequel l'accesoire suit le sort du principal, la grève de solidarité qui appui un mouvement illegal acquiert elle-même ce caractère (Cass.soc., 21 févr. 1952: Dr. soc. 1952, p. 325. - cass. soc., 20 nov. 1952: Dr. soc. 1953, p. 99. - cass. soc., 4 oct. 1956: D. 1957, jurispr. P. 51 apud TEYSSIÉ, Bernard. Grève dans le secteur privé. Jurisclasseur Travail Traité, fasc. 70-10, 15 avril 2010).

${ }^{329}$ Cass. crim., 12 janv. 1971: Dr. soc. 1971, p. 547, obs. J. Savatier. - Adde, Cass. crim., 23 oct.. 1969: Dr. 1970, jurispr.. p. 129, note H. Sinay. - Cass. soc., 30 mars 1981: JCP G 1971, II, 16883, note H. Groutel apud TEYSSIÉ, Bernard. Grève dans le secteur privé. Jurisclasseur Travail Traité, fasc. 70-10, 15 avril 2010.

${ }^{330}$ TEYSSIÉ, Bernard. Grève dans le secteur privé. Jurisclasseur Travail Traité, fasc. 70-10, 15 avril 2010.

331 V. Cass. soc., 17 déc. 2003: RJS 2004, n. 339 apud TEYSSIÉ, Bernard. Grève dans le secteur privé. Jurisclasseur Travail Traité, fasc. 70-10, 15 avril 2010.
} 
corte francesa não reconhece sua regularidade se ele apoia um movimento ilícito. Aplica-se neste caso o princípio segundo o qual o acessório segue a mesma sorte do principal $^{332}$.

Quando o conflito principal se desenvolve dentro de condições regulares, é preciso analisar o vigor da ligação existente entre as reivindicações suscitadas pelos grevistas e os interesses dos empregados associados ao movimento de apoio. A greve será regular quando os empregados de uma empresa se associem a um movimento de protesto baseado em reivindicações que "pour être générales et communes à un três grand nombre de travailleurs, n'en étaient pas moins de nature à les intéresser"333.

\subsubsection{O direito de greve e a imposição de procedimentos prévios}

O Comitê de Liberdade Sindical da OIT admite que a legislação dos países membros estabeleça condições para que a greve seja considerada lícita. Exige, para tanto, que estas condições sejam razoáveis e, em todo caso, que não constituam uma limitação importante às possibilidades de ação das organizações sindicais ${ }^{334}$, nem complicados ao ponto de tornar impossível uma greve legal ${ }^{335}$. Ele não considera atentatória à liberdade sindical uma legislação que preveja procedimentos de conciliação e arbitragem voluntária nos conflitos coletivos como condição prévia à declaração de uma greve. $\mathrm{O}$ recurso à arbitragem, contudo, não pode apresentar caráter obrigatório nem tampouco impedir, na prática, o recurso à greve ${ }^{336}$ e eventual limitação momentânea ao direito de greve para que

\footnotetext{
${ }^{332}$ Cass. soc., 21 févr. 1952: Dr. soc. 1952. P. 325; Cass.soc., 20 nov. 1952: Dr. soc. 1953, p. 99. - Cass. soc., 4 oct. 1956: D. 1957, jurispr. P. 51. Ibidem.

${ }^{333}$ Cass. crim., 12 janv. 1971: Dr. soc. 1971, p. 547, obs. J. Savatier. - Adde, Cass. crim., 23 oct. 1969: D. 1970, jurispr. P. 129, note H. Sinay, - Cass. soc., 30 mars 1971: JCP G 1971, II, 16883, note H. Groutel. Ibidem.

${ }^{334}$ Precedente 547 da $5^{\text {a }}$ edição da Recopilación de decisiones y princípios del Comité de Libertad Sindical del Consejo de Administración de la OIT que assim dispõe: "Las condiciones requeridas por la legislación para que la huelga se considere un acto lícito deben ser razonables y, en todo caso, no de tal naturaleza que constituyan una limitación importante a las posibilidades de acción de las organizaciones sindicales". (Véanse Recopilación de 1996, párrafo 498; 300. ${ }^{\circ}$ informe, caso núm. 1799, párrafo 207; 318. ${ }^{\circ}$ informe, caso núm. 2018, párrafo $514 ; 325 .^{\circ}$ informe, caso núm. 2049, párrafo 520; $327 .^{\circ}$ informe, caso núm. 2118, párrafo 635 y 333.er informe, caso núm. 2251, párrafo 995.)

${ }^{335}$ Precedente 548 da $5^{\mathrm{a}}$ edição da Recopilación de decisiones y princípios del Comité de Libertad Sindical del Consejo de Administración de la OIT que assim dispõe: "Los procedimientos legales para declarar una huelga no deberían ser complicados al punto de que en la práctica resulte imposible una huelga legal".(Véase Recopilación de 1996, párrafo 499 y 316. informe, caso núm. 1989, párrafo 189.)

${ }^{336}$ Precedente 549 da $5^{a}$ edição da Recopilación de decisiones y princípios del Comité de Libertad Sindical del Consejo de Administración de la OIT que assim dispõe: "No puede considerarse como atentatoria a la libertad sindical una legislación que prevé procedimientos de conciliación y arbitraje (voluntario) en los conflictos colectivos como condición previa a la declaración de una huelga siempre y cuando el recurso al arbitraje no tenga carácter obligatorio y no impida en la práctica el recurso a la huelga". (Véanse
} 
se esgotem todos os meios existentes de negociação, conciliação e arbitragem, deveria ir acompanhada de procedimentos de conciliação e arbitragem adequados, imparciais e rápidos em que os interessados possam participar em todas as etapas ${ }^{337}$.

A legislação brasileira exige expressamente o esgotamento da via negocial ou a impossibilidade de recursos à via arbitral, para que a paralisação possa ser reputada legítima (Art. $3^{\circ}$, caput da Lei 7.783/90). Homero Batista Mateus da Silva considera necessário, para o cumprimento do primeiro destes requisitos, que o sindicado responsável pelo movimento se muna de comprovações em torno das mesas redondas e troque de correspondências com a entidade patronal ou com os empregadores diretamente envolvidos. E observa que a mera exortação à negociação ou ao escoamento de prazos em silêncio não são formas válidas de esgotamento da via negocial ${ }^{338}$.

Otavio Pinto e Silva observa que a Lei 7.783/89 não indica quando ou como a negociação pode ser caracterizada como frustrada, de maneira a possibilitar o recurso à greve. Esclarece ainda haver, na doutrina, dois critérios o da recusa e o do desacordo. A recusa em negociar se daria de modo expresso quando o empregador afirma (por escrito ou verbalmente) que não conversará sobre as reivindicações formuladas e de modo tácito quando deixa de responder ao pleito do sindicato em um determinado prazo $^{339}$. O desacordo se verificaria com a não aceitação pelo empregador das reivindicações apresentadas. Apesar de não haver a recusa aos entendimentos, se considera eles infrutíferos, caracterizando a negociação como frustrada, no sentido da exigência legal. Poder-se-ia falar ainda em desacordo quando se inviabiliza a via arbitral. Uma proposta de arbitragem recusada pelo empregador teria o mesmo efeito da frustração da negociação.

Recopilación de 1996, párrafo 500; 307. informe, caso núm. 1899, párrafo 83, caso núm. 1898, párrafo 324; $309 .^{\circ}$ informe, caso núm. 1912, párrafo 364; 324. ${ }^{\circ}$ informe, casos núms. 2292 y 2101, párrafo 731 y $336 .^{\circ}$ informe, caso núm. 2369, párrafo 212.)

${ }^{337}$ Precedente 551 da $5^{\text {a }}$ edição da Recopilación de decisiones y princípios del Comité de Libertad Sindical del Consejo de Administración de la OIT que assim dispõe: "El Comité ha insistido sobre el hecho de que, aun cuando la huelga pueda ser momentáneamente limitada por ley hasta que se agoten todos los médios existentes de negociación, conciliación y arbitraje, tal limitación debería ir acompañada de procedimientos de conciliación y arbitraje adecuados, imparciales y rápidos en que los interesados puedan participar en todas las etapas". (Véase Recopilación de 1996, párrafo 501.)

338 SILVA, Homero Mateus Batista da. Curso de direito do trabalho aplicado, vol. 7: direito coletivo do trabalho. Rio de Janeiro: Elsevier, 2010, p. 260.

${ }^{339}$ SILVA, Otavio Pinto e. A contratação coletiva como fonte do direito do trabalho. São Paulo: LTr, 1998, p. 95. Lembra referido autor que a CLT dispõe que as partes não podem se recusar a negociar (art. 616, caput), sendo possível então a utilização de um mecanismo para promover a negociação com quem não a deseja: o pedido de instauração de mesa-redonda perante a Delegacia Regional do Trabalho, que implica a convocação compulsória da parte recalcitrante (art. $616, \S 1^{\circ}$ ). Aludido procedimento permaneceria, em sua opinião, válido mesmo após a Constituição de 1988, pois representa apenas um mecanismo de mediação, não significando intervenção na organização sindical (idem, p. 97). 
Em outras palavras, se o sindicato dos trabalhadores demonstrar que propôs a solução do conflito por meio da arbitragem, sem ser atendido, também estaria legitimado para a deflagração da greve ${ }^{340}$.

A Subeção de Dissídios Coletivos do Tribunal Superior do Trabalho enaltece a importancia de se observar este requisito para o exercício do direito de greve na sua Orientação Jurisprudêncial de n. 11, que dispõe que "é abusiva a greve levada a efeito sem que as partes tenham tentado, direta e pacificamente, solucionar o conflito que lhe constitui o objeto".

No tocante ao recurso à arbitragem algumas considerações precisam ser feitas. Primeiramente há que se reconhecer que em matéria de dissídios individuais elas nunca conquistaram ampla simpatia entre os operadores do direito do trabalho, não obstante se encontrem registros de decisões judiciais as reconhecendo e textos doutrinários defendendo-a com argumentos no mínimo respeitáveis. Como salienta Homero Batista Mateus da Silva, a arbitragem não encontrou aceitação no Brasil em razão do histórico de abusos e fraudes perpetrados nesta forma alternativa de solução de conflitos. Não se trata, portanto, nem de um problema de ordem legal, já que há lei disciplinando-a, nem tampouco de ordem conceitual, haja vista não faltarem estudos e elogios às virtudes da arbitragem $^{341}$.

No tocante aos dissídios coletivos, hipótese que mais importa para os fins estudados neste tópico, a sua escassa utilização seria fruto, segundo argumentam os sindicatos, da parcialidade dos árbitros, da falta de clareza das decisões, da ausência de profissionais qualificados e da imprevisibilidade das decisões ${ }^{342}$. Por tudo isso, haveria até hoje uma preferência ao recurso à solução jurisdicional, que será estudada em momento oportuno, o que levou Homero Mateus Batista da Silva a asseverar que "Verdadeiramente, a única arbitragem praticada no direito do trabalho brasileiro é aquela compulsória, representada pelo poder normativo do tribunal do trabalho" 343 .

Uma das exigências procedimentais mais comuns no que diz respeito ao exercício do direito de greve é a de pré-aviso, que o Comitê de Liberdade Sindical considera

\footnotetext{
${ }^{340}$ Ibidem.

${ }^{341}$ SILVA, Homero Mateus Batista da. Curso de direito do trabalho aplicado, vol. 7: direito coletivo do trabalho. Rio de Janeiro: Elsevier, 2010, p. 262.

${ }^{342}$ Ibidem, p. 263.

${ }^{343}$ Ibidem.
} 
admissível $^{344}$. Os países que adotam este tipo de exigência findam por vetar as chamadas greves surpresas, também chamada greve selvagem, que, segundo Homero Batista Mateus da Silva, "não merecem o tratamento como um direito exercido responsavelmente pelos trabalhadores, pois frustra o espírito da negociação e não atende aos anseios de melhoria das condições de trabalho" 345 .

Na França, segundo Pélissier, Supiot e Jeammaud, não obstante a greve suponha a existência de reivindicações não satisfeitas, a lei não prevê a maneira como essas reivindicações deverão ser comunicadas ao empregador, nem mesmo estabelece uma fase prévia em que o empregador deverá se recusar a satisfazer as reivindicações apresentadas. Após diversas exitações, a jurisprudência passou a exigir que as reivindicações sejam apresentadas e a entender que a paralisação do trabalho deve suceder e não preceder a formulação de reivindicações, muito embora a greve possa preceder a rejeição destas reivindicações por parte do empregador ${ }^{346}$. É curioso observar que apesar de entender que a apresentação das reivindicações é uma exigência para o exercício do direito de greve, as cortes francesas entendem que a livre escolha do momento implica na ausência de todas as formalidades prévias, e, por conseguinte, como exaltam os autores citados, "La grève sans avertissement n'est pas irrégulière. On parle de greve $<<$ surprise $>>$. Cela signifie seulement que le déclenchement de la grève n'est soumis à aucune procédure" ${ }^{347}$. Nos serviços públicos, entretanto, a situação é diversa, já que "Condamnant la greve suprise l'article L. 521-3 dispose que la cessation concertée du travail doit être précédée d'um préavis" 348 .

Referido comitê já decidiu pela validade inclusive de preaviso de 20 dias para realização de greve em atividades essenciais ${ }^{349}$. Também já admitiu como válida norma de legislação nacional que instituiu um período de reflexão de 40 dias antes da declaração da

\footnotetext{
${ }^{344}$ Precedente 552 da $5^{\text {a }}$ edição da Recopilación de decisiones y princípios del Comité de Libertad Sindical del Consejo de Administración de la OIT que assim dispõe: "La obligación de dar un preaviso al empleador o a su organización antesde declarar una huelga puede ser considerada como admisible". (Véase Recopilación de 1996, párrafo 502; 325. ${ }^{\circ}$ informe, caso núm. 2049, párrafo 520 y 333 informe, caso núm. 2251, párrafo 996.)

${ }^{345}$ SILVA, Homero Mateus Batista da. Op cit, p. 264.

${ }^{346}$ PÉLISSIER, Jean; SUPIOT, Alain; JEAMMAUD, Antoine. Droit du travail. 21 ed. Paris: Dalloz, 2002, pp. $1230 / 1231$.

${ }^{347}$ Idem, p. 1231.

${ }^{348}$ Idem, p. 1231.

${ }^{349}$ Precedente 553 da $5^{\text {a }}$ edição da Recopilación de decisiones y princípios del Comité de Libertad Sindical del Consejo de Administración de la OIT que assim dispõe: "El requisito de un preaviso de 20 días no atenta contra los principios de la libertad sindical en los servicios de interés social o público". (Véase Recopilación de 1996, párrafo 504; 309..$^{\circ}$ informe, caso núm. 1912, párrafo 365.)
} 
greve num serviço essencial por considerar que durante este período as partes poderiam estabelecer novas negociações e, eventualmente, chegar a um acordo sem ter que recorrer à greve $^{350}$.

O comitê de liberdade sindical considera que a decisão de suspender uma greve por um período razoável com o fim de permitir que as partes logrem uma solução negociada mediante esforços de mediação ou conciliação não constitui, em si, uma violação dos

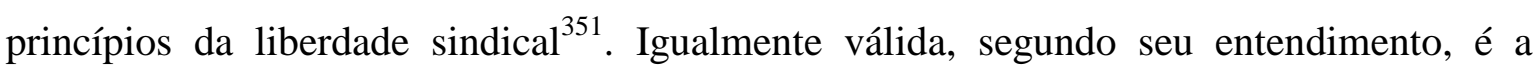
obrigação de respeitar um determinado quórum e de tomar a decisão de fazer greve por meio de escrutínio secreto $^{352}$. Se o quórum, entretanto, for estipulado de maneira a inviabilizar ou dificultar demasiadamente a decisão da categoria haverá efetiva violação aos direitos de liberdade sindical. Sobretudo quando houver cominação de sanção para a inobservância dele $\mathrm{e}^{353}$. Dois terços dos integrantes da categoria configuraria um quórum possivelmente muito difícil de alcançar, particularmente quando os sindicatos tem um grande número de filiados ou cobrem território vasto ${ }^{354}$. Considerou-se em determinada ocasião que exigir deliberação da maioria absoluta de trabalhadores vinculados em uma declaração de greve pode resultar difícil de alcançar, particularmente naqueles sindicatos

\footnotetext{
${ }^{350}$ Precedente 554 da $5^{\text {a }}$ edição da Recopilación de decisiones y princípios del Comité de Libertad Sindical del Consejo de Administración de la OIT que assim dispõe: "La exigencia legal de un período de reflexión de 40 días antes de la declaración de una huelga en un servicio esencial, tiene la fi nalidad de otorgar a las partes un plazo de reflexión, no es contraria a los principios de la libertad sindical. Esta cláusula de contemporización puede permitir a ambas partes entablar nuevas negociaciones y, eventualmente, llegar a un acuerdo sin tener que recurrir a la huelga". (Véase Recopilación de 1996, párrafo 505.)

${ }^{351}$ Precedente 550 da $5^{\mathrm{a}}$ edição da Recopilación de decisiones y princípios del Comité de Libertad Sindical del Consejo de Administración de la OIT que assim dispõe: "En general, la decisión de suspender una huelga por un período razonable con el fin de permitir a las partes lograr una solución negociada mediante esfuerzos de mediación o conciliación no constituye en sí una violación de los principios de la libertad sindical". (Véase 338, ${ }^{\circ}$ informe, caso núm. 2329, párrafo 1274.)

${ }^{352}$ Precedente 559 da $5^{\mathrm{a}}$ edição da Recopilación de decisiones y princípios del Comité de Libertad Sindical del Consejo de Administración de la OIT que assim dispõe: "La obligación de respetar un determinado quórum y de tomar la decisión de hacer huelga por medio de escrutinio secreto puede considerarse admisible". (Véanse Recopilación de 1996, párrafo 510; 316. ${ }^{\circ}$ informe, caso núm. 1989, párrafo 190 y 332. ${ }^{\circ}$ informe, caso núm. 2216, párrafo 912).

${ }^{353}$ Precedente 555 da 5 a edição da Recopilación de decisiones y princípios del Comité de Libertad Sindical del Consejo de Administración de la OIT que assim dispõe: " En lo que se refiere a la mayoría exigida por una legislación para la declaración de una huelga legal (dos tercios de los votos de la totalidad de los miembros de la organización o sección), condición que, en caso de no ser cumplida, puede acarrear una sanción por parte de las autoridades administrativas, inclusive la disolución del sindicato, el Comité recordó las conclusiones de la Comisión de Expertos en Aplicación de Convenios y Recomendaciones, en el sentido de que la disposición legal aludida constituye una intervención de las autoridades públicas en la actividad de los sindicatos, intervención que tiende a limitar los derechos de estas organizaciones contra lo dispuesto en el artículo 3 del Convenio". (Véase Recopilación de 1996, párrafo 506.)

${ }^{354}$ Precedente 560 da $5^{\text {a }}$ edição da Recopilación de decisiones y princípios del Comité de Libertad Sindical del Consejo de Administración de la OIT que assim dispõe: "Un quórum de dos tercios de los miembros podría ser difícil de alcanzar, en particular cuando los sindicatos tienen un gran número de afiliados o cubren un territorio vasto". (Véanse Recopilación de 1996, párrafo 511; 332. ${ }^{\circ}$ informe, caso núm. 2216, párrafo 912 y 333.er informe, caso núm. 2251, párrafo 987.)
} 
que agrupam um grande número de filiados, implicando em risco de limitação excesiva ao direito de greve $^{355}$. Em outras oportunidades entendeu-se que mesmo a exigência de decisão da metade dos trabalhadores concernentes à greve era demasiadamente elevada e poderia dificultar excessivamente a possibilidade de efetuar a greve, sobretudo em grandes corporações $^{356}$.

Ainda sobre a exigência de deliberação da categoria para autorizar o movimento grevista, é importante registrar que o Comitê de Liberdade Sindical já estatui que subordinar a declaração de greve ao acordo da maioria dos filiados em federações e confederações e ao voto afirmativo da maioria absoluta dos trabalhadores da empresa podem consistir uma limitação importante às possibilidade de ação das organizações sindicais $^{357}$. Também já considerou que, conforme os princípios da liberdade sindical, a decisão concernente à declaração de uma greve nas seções locais de uma organização sindical pode ser adotada pela assembléia geral das seções locais, se o motivo da greve é de índole local e que, nas organizações sindicais de grau superior, a decisão da declaração de greve pode ser adotada pelo comitê de direção destas organizações por maioria absoluta de votos de todos os membros do comitêt $\hat{e}^{358}$.

\footnotetext{
${ }^{355}$ Precedente 557 da $5^{\text {a }}$ edição da Recopilación de decisiones y princípios del Comité de Libertad Sindical del Consejo de Administración de la OIT que assim dispõe: "La mayoría absoluta de trabajadores vinculados en una declaración de huelga puede resultar difícil de alcanzar, particularmente en aquellos sindicatos que agrupan a un gran número de afiliados. Esta disposición puede entrañar, pues, un riesgo de limitación importante al derecho de huelga".(Véanse Recopilación de 1996, párrafo 508 y 316. informe, caso núm. 1989, párrafo 190.)

${ }^{356}$ Precedente 556 da $5^{\text {a }}$ edição da Recopilación de decisiones y princípios del Comité de Libertad Sindical del Consejo de Administración de la OIT que assim dispõe: “ La exigencia de la decisión de más de la mitad de todos los trabajadores concernidos para declarar una huelga es demasiado elevada y podría dificultar excesivamente la posibilidad de efectuar la huelga, sobre todo en grandes empresas". (Véase Recopilación de 1996, párrafo 507). Conclusão parecida foi adotada também no Precedente 558 da $5^{\text {a }}$ edição da Recopilación de decisiones y princípios del Comité de Libertad Sindical del Consejo de Administración de la OIT que assim dispõe: "El Comité pidió a un gobierno que tome medidas para modificar el requisito legal relativo a la necesidad de que la decisión de declaración de la huelga sea adoptada por más de la mitad de los trabajadores a los que la misma comprende, particularmente en aquellas empresas donde hay un gran número de afiliados". (Véase Recopilación de 1996, párrafo 509.).

${ }^{357}$ Precedente 561 da $5^{\mathrm{a}}$ edição da Recopilación de decisiones y princípios del Comité de Libertad Sindical del Consejo de Administración de la OIT que assim dispõe: "Subordinar la declaración de huelga al acuerdo de la mayoría de los afiliados en las federaciones y confederaciones y la del voto afirmativo de la mayoría absoluta de los trabajadores de la empresa pueden constituir una limitación importante a las posibilidades de acción de las organizaciones sindicales". (Véase Recopilación de 1996, párrafo 512).

${ }^{358}$ Precedente 562 da $5^{\mathrm{a}}$ edição da Recopilación de decisiones y princípios del Comité de Libertad Sindical del Consejo de Administración de la OIT que assim dispõe: "El Comité ha considerado, conforme con los principios de la libertad sindical, que la decisión concerniente a la declaración de una huelga en las secciones locales de una organización sindical pueda ser adoptada por la asamblea general de las secciones locales, si el motivo de la huelga es de índole local, y que, en las organizaciones sindicales de grado superior, la decisión de la declaración de huelga puede ser adoptada por el comité de dirección de estas organizaciones por mayoría absoluta de votos de todos los miembros del comité". (Véase Recopilación de 1996, párrafo 513.)
} 
Ainda acerca dos procedimentos de votação, o Comitê de Liberdade Sindical consignou que a obrigação legal de proceder a uma segunda votação de a greve não foi efetuada no prazo de três meses após a primeira votação não constitui uma ameaça para a liberdade sindical ${ }^{359}$.

Não obstante se mostrem em consonância com os precedentes do Comitê de Liberdade Sindical da Organização Internacional do Trabalho, os procedimentos exigidos para deflagração de greve no Brasil, vêm, em determinadas ocasiões, esvaziando o exercício do direito de greve.

A exigência de pré-aviso, por exemplo, tem, em muitas ocasiões, possibilitado que empregadores ajuízem ações para enfraquecer o movimento paredista com provimentos que vão desde autorização à utilização de força policial até cominações em obrigação de fazer ou não fazer sujeitas a penas altíssimas.

Demais disso, situações há em que as reivindicações dos trabalhadores não podem esperar o decurso do aludido prazo de pré-aviso, nem tampouco as formalidades atinentes às tentativas de negociação. É o que ocorre, por exemplo, nos casos de paralisações que busquem melhoria nas condições de segurança e saúde no trabalho, as chamadas greves ambientais, que, segundo Mariella Carvalho de Farias Aires, "teriam a natureza jurídica de 'garantia fundamental' a serviço do trabalhador, visando à tutela de sua saúde e de sua segurança, ou em última análise, de sua vida" ${ }^{360}$. Ao prefaciar obra desta pesquisadora, Ari Pedro Lorenzetti consignou com grande acerto que:

Quando, porém, a greve visa obter melhores condições de trabalho, incluindo, ou não, questões ambientais, é conveniente que se exijam certas medidas preparatórias, a fim de que os efeitos da greve não tragam consequências danosas sobre toda a sociedade ou para a própria continuidade do contrato de trabalho. Todavia, existem situações em que, dada a iminência dos riscos à vida, à integridade física ou à saúde dos trabalhadores, não seria razoável impor um ritual prévio para que os trabalhadores pudessem reagir a tal situação. Qualquer proteção, em tais

\footnotetext{
${ }^{359}$ Precedente 563 da $5^{\text {a }}$ edição da Recopilación de decisiones y princípios del Comité de Libertad Sindical del Consejo de Administración de la OIT que assim dispõe: "La obligación legal de proceder a una segunda votación si la huelga no se produjo en el plazo de los tres meses siguientes a la primera votación, no constituye una amenaza para la libertad sindical”. (Véase Recopilación de 1996, párrafo 514.)

${ }^{360}$ AIRES, Mariella Carvalho de Farias. Direito de greve ambiental no ordenamento jurídico brasileiro. Goiânia: Ed. Da UCG, 2008, p. 111.
} 
casos, poderia ser fatal. Entre o cumprimento das regras da lei de greve, com a frustração de seu objetivo e a consequente provocação de danos irreversíveis à pessoa dos trabalhadores, e a adoção de uma medida drástica, mas eficiente, quando seja a única forma razoável para evitar o dano, esta deve ser a solução preferível. A escolha, porém, deve ser feita caso a caso, e a avaliação da legalidade da opção também deve considerar a situação concreta, sem se prender a esquemas pré-fixados ${ }^{361}$.

Sob esta perspectiva, a chamada greve ambiental se assemelha as figuras da legítima defesa e do estado de necessidade, tratadas como excludente de ilicitude no artigo 23, I e II do Código Penal Brasileiro (Decreto-lei 2.848/40). Ora, se determinado ilícito, quando praticado em estado de necessidade, não é considerado delito, nada mais justo do que não considerar abusiva uma greve que descumpriu uma das formalidades para deflagração da greve, quando justificada pela tentativa de se salvar de perigo atual, que não provocou por sua vontade, nem podia de outro modo evitar.

Não fosse isso o bastante, a fixação do prazo em horas, se levada a exigência de cumprimento de todo o período de aviso prévio com máximo rigor, pode resultar no reconhecimento da abusividade de uma greve comunicada às nove horas da manhã da quinta-feira, no primeiro momento da jornada comercial, para ter início na mudança de turno do sábado que, entretanto, ocorre às seis horas da manhã. Não é razoável pensar que essas três horas seriam tão imprescindíveis assim para a organização empresarial e para viabilizar a retomada das negociações que a sua falta justifique a penalização de todo o movimento. A boa-fé dos trabalhadores fica evidenciada no fato de a comunicação ter sido feita no primeiro momento possível da antevéspera da paralisação.

Demais disso, propõe-se neste trabalho uma releitura acerca do conceito de abusividade da greve. Não obstante o artigo 14 da Lei 7.783/89 repute abusiva toda e qualquer greve deflagrada sem a observância das normas nela contida, é forçoso reconhecer que o artigo $9^{\circ}$ da Constituição assegura de forma ampla o direito de greve, atribuindo à lei infraconstitucional apenas três tarefas: definir os serviços ou atividades essenciais, dispor sobre o atendimento das necessidades inadiáveis da comunidade; e sujeitar os abusos cometidos às penas da lei.

\footnotetext{
${ }^{361}$ Ibidem.
} 
Observe-se que em uma interpretação estrita, como a que ora propomos, o constituinte delegou à lei a atribuição de definir as sanções pelo abuso e não o que se deve reputar ato abusivo. Diante da constatação já feita de que o direito de greve, por sua própria natureza, implica inevitavelmente na colisão com outros direitos fundamentais e que, ainda que no modelo proposto se parta sempre da presunção de legitimidade da greve, não seria prudente estipular um rol taxativo para as hipóteses de abusividade do movimento puníveis na forma da lei. A abusividade, segundo tese que hora se propõe, deve ser analisada casuisticamente pelo órgão julgador, quando a questão vier a ser judiciarizada e não for solucionada consensualmente, a ele caberá averiguar a boa-fé objetiva das partes na negociação, observar se a paralisação atingiu a produção da empresa e não a sua produtividade, e analisar eventuais excessos do movimento grevista já deflagrado que tenham causado prejuízo desproporcional ao empregador. O cumprimento dos requisitos da lei 7.783/89, particularmente o pré-aviso, o esgotamento das vias negociais e a disposição em ajustar a continuidade das atividades que não podem ser paralisadas devem ser vistos como demonstração de boa-fé objetiva e não analisados como condição sine qua non para que se reconheça a legitimidade do movimento. A partir deste ponto de vista é possível reconhecer legitimidade a um movimento, ainda que nem todas as formalidades para a deflagração da greve tenham sido observadas.

\subsubsection{Situações em que não se permite movimento grevista}

O legislador francês expressamente privou determinadas categorias de recorrer à greve para reinvindicar melhoria em suas condições. São elas: militares ${ }^{362}$, policiais ${ }^{363}$, agentes penitenciários ${ }^{364}$, magistrados ${ }^{365}$, trabalhadores do serviço de transmissão do ministério do interior ${ }^{366}$, engenheiros de estudos e de exploração da aviação civil ${ }^{367}$. Isto, contudo, não as impediu de organizar movimentos paredistas. Muito pelo contrário. Segundo Jean Pélissier, Alain Supiot e Anoine Jeammaud, estas vedações suscitaram greves para conquista ou reconquista do direito de organizar paralisações coletivas ${ }^{368}$.

\footnotetext{
${ }^{362}$ Loi 13 juillet 1972.

${ }^{363}$ Lois 27 décembre 1947 et 28 septembre 1948.

364 Ord. 6 aôut 1958.

365 Ord. 22 déc. 1958 (art. 10).

${ }^{366}$ Loi de finances du 31 juillet 1978 (art. 14).

${ }^{367}$ Loi du 17 juin 1971.

368 PÉLISSIER, Jean; SUPIOT, Alain; JEAMMAUD, Antointe. Droit du travail. 21a ed. Paris: Dalloz, 2002, p. 1227.
} 
O Comitê de Liberdade Sindical da OIT, há que se ressaltar, admite este tipo de restrição ao direito de greve em relação aos funcionários públicos que exercem funções de autoridade em nome do Estado e em relação aos trabalhadores de serviços essenciais no sentido estrito do termo, ou seja, aqueles cuja interrupção poderia colocar em perigo a vida, a segurança ou a saúde de toda ou de parte da população ${ }^{369}$.

No Brasil o artigo 142, $\S 5^{\circ}$ da Constituição Federal lhes proíbe expressamente os militares de se sindicalizar e de fazer greve ${ }^{370}$. Embora essa regra esteja no capítulo atinente às forças armadas, ela também se aplica aos militares estaduais, como policiais e bombeiros, por força do que estatui o artigo $42, \S 1^{\circ}$ da Carta Magna ${ }^{371}$.

Bastante tormentosa é a discussão acerca do direito de greve dos magistrados no Brasil. Em interessante artigo Luis Carlos Moro posiciona-se contrariamente a esta possibilidade. Analisando a manifestação feita pelos magistrados federais e do trabalho em 30 de novembro de 2011, afirmou que apesar da aparência de greve ela não pode receber esse título porquanto os Juízes são órgãos de Poder, assim definidos constitucionalmente, e Poder não suspende suas atividades. Não se paralisa, catatônico, à espera de um milagre ou de que se lhe ouça, quando não se faz ouvir. Em sua opinião, ao declararem greve, os juízes se qualificam como meros prestadores de serviços jurisdicionais, olvidando a sua face de Poder de Estado, únicos indivíduos a receberem, juntamente com o Presidente da República e chefes do Executivo, a condição de órgão singular de Estado. E afirma em remate que os magistrados grevistas:

\footnotetext{
${ }^{369}$ Precedente 541 da $5^{\text {a }}$ edição da Recopilación de decisiones y princípios del Comité de Libertad Sindical del Consejo de Administración de la OIT que assim dispõe: "El Comité ha mantenido en reiteradas ocasiones la legitimidad de las huelgas de ámbito nacional, en la medida que tengan objetivos económicos y sociales y no puramente políticos; la prohibición de la huelga sólo podría ser aceptable con respecto a los funcionarios públicos, que ejercen funciones de autoridad en nombre del Estado (Nota 1) o con respecto a los trabajadores de los servicios esenciales en el sentido estricto del término (es decir, aquellos servicios cuya interrupción podría poner en peligro la vida, la seguridad o la salud de la persona en toda o parte de la población). (Véase Recopilación de 1996, párrafo 492.).

370 Art. 142. As Forças Armadas, constituídas pela Marinha, pelo Exército e pela Aeronáutica, são instituições nacionais permanentes e regulares, organizadas com base na hierarquia e na disciplina, sob a autoridade suprema do Presidente da República, e destinam-se à defesa da Pátria, à garantia dos poderes constitucionais e, por iniciativa de qualquer destes, da lei e da ordem. (...)§ $3^{\circ}$ Os membros das Forças Armadas são denominados militares, aplicando-se-lhes, além das que vierem a ser fixadas em lei, as seguintes disposições: (...)IV - ao militar são proibidas a sindicalização e a greve;

${ }^{371}$ Art. 42 Os membros das Polícias Militares e Corpos de Bombeiros Militares, instituições organizadas com base na hierarquia e disciplina, são militares dos Estados, do Distrito Federal e dos Territórios.

$\S 1^{\circ}$ Aplicam-se aos militares dos Estados, do Distrito Federal e dos Territórios, além do que vier a ser fixado em lei, as disposições do art. $14, \S 8^{\circ}$; do art. $40, \S 9^{\circ}$; e do art. 142 , $\S \S 2^{\circ}$ e $3^{\circ}$, cabendo a lei estadual específica dispor sobre as matérias do art. $142, \S 3^{\circ}$, inciso $\mathrm{X}$, sendo as patentes dos oficiais conferidas pelos respectivos governadores.
} 
Vestem o uniforme da subordinação, e subordinam a própria ação ao atendimento de reivindicação econômica mínima. Trocam o máximo, a condição de órgãos de Poder controlador da constitucionalidade e liceidade de todos os atos, pelo mínimo. E o fazem com incompatível ausência de humildade, com a pretensão de que a paralisação de suas atividades fosse causar uma autêntica débâcle nos demais Poderes da República. O que se vê, no entanto, é a baixíssima capacidade de mobilização social dos magistrados. Correm o risco de verem seu movimento passar despercebido. Se notado, é visto como burlesco.

"Greve de juízes" não exerce coação sobre ninguém, senão sobre a população jurisdicionada. E, nesse sentido, o movimento é um erro brutal. Não atrai a simpatia dos partícipes da Justiça, senão de uma minoria. E angaria um enorme plexo de detratores da magistratura e do instituto da greve como direito. Na prática, o imobilismo dos juízes não mobiliza a quase ninguém, senão a poucos interessados ${ }^{372}$.

Não obstante alicerçado em argumentos muito sólidos e bem fundamentados, não há como concordar com a opinião do respeitado advogado. Não obstante estejam investidos de poder estatal, os magistrados são, inegavelmente, trabalhadores. A regra geral do artigo $9^{\circ}$ da Constituição também se lhes é dirigida. Como integram o serviço público na condição de agentes políticos, sendo, portanto, servidores públicos em sentido lato, os magistrados sujeitar-se-ão ao que vier a ser disposto pela lei específica sobre greve prevista no artigo 37, VII que poderá, em verdade deverá incluir a prestação jurisdicional como atividade pública essencial criando algumas exigências para o exercício de greve neste campo. Não poderá, contudo, vedar integralmente o seu exercício. A opinião sustentada neste trabalho é a de que somente a Constituição poderá vedar movimentos grevistas, como o fez em relação aos militares das forças armadas.

372 MORO, Luís Carlos. Os juízes grevistas vistos por um advogado trabalhista. Consultor Jurídico. Disponível em: < http://www.conjur.com.br/2011-dez-'01/juizes-grevistas-vistos-advogado-trabalhista>. Acesso em 28/12/11. 
3 NOVA FEIÇÃO DA GREVE

Há muitos anos a doutrina vem alertando para as modificações que a nova ordem econômica mundial vem acarretando no direito do trabalho, em particular nas relações coletivas de trabalho. A relação de competitividade imposta pelo mercado global justificou uma radical modificação na forma de pensar a doutrina que sustentava o estado do bemestar social e as garantias dos trabalhadores em todo o sistema ocidental ${ }^{373}$. Surgiram as teorias flexibilizadoras ${ }^{374}$ que ganham ou perdem adeptos conforme o cenário econômico de cada momento.

Em estudo publicado no início dos anos dois mil pela Organização Internacional do Trabalho, Armand F. Pereira, então Diretor da OIT para o Brasil, alertava para o fato de as estatísticas disponíveis e comparáveis por grupo de atividade econômica sugerirem uma aparente tendência de decréscimo, nos anos 90, do número de greves e lock-outs, bem como do número de trabalhadores envolvidos e do número de dias não trabalhados por consequência delas. Considera-se que os dados poderiam sugerir uma mistura de diversas hipóteses, tais como: menor conflito aberto nas relações de trabalho, menor influência de rigidez ideológica na abordagem e resolução dos conflitos coletivos, maior propensão a negociações coletivas, redução dos níveis gerais de sindicalização especialmente durante a última década, ou talvez menor poder aparente dos sindicatos de trabalhadores, ou mesmo

\footnotetext{
${ }^{373}$ ORLANDINI, Giovanni. Sciopero e servizi pubblici essenciali nel processo d'integrazione europea: uno Studio di diritto comparato e comunitário. Torino: Giappichelli editore: 2003, p. 1. Em relação à doutrina nacional, cabe transcrever a seguinte observação do professor Ari Possidônio Beltran: "Medidas como desativação de setores, a terceirização, a aplicação de novos aparatos tecnológicos que impliquem a redução de postos de trabalho, sem prejuízo da produção, a robotização, constituem enfim algumas medidas de enorme gama de que podem utilizar-se os empresários (BELTRAN, Ari Possidônio. A autotutela nas relações do trabalho. São Paulo: LTr, 1996, p. 195)

${ }^{374}$ Como salienta Oscar Ermida Uriarte, em termos muito gerais e no âmbito do Direito do Trabalho, a flexibilidade pode ser definida como eliminação, diminuição, afrouxamento ou adaptação da proteção trabalhista clássica, com a finalidade - real ou pretensa - de aumentar o investimento, o emprego ou a competitividade da empresa (ERMIDA URIARTE, Oscar. A flexibilidade. São Paulo: LTr, 2002, p. 9).
} 
uma provável menor tolerância de consumidores a efeitos de reinvindicações trabalhistas na oferta ou preços de serviços e bens de consumo, etc ${ }^{375}$.

Afirmou-se na mesma obra que as mudanças tecnológicas e a flexibilização da produção, bem como as mudanças decorrentes na estrutura do mercado de trabalho, certamente teriam alguma influência indireta sobre muitas dessas hipóteses que supostamente explicariam o menor poder de mobilização para greves. Por outro lado, algumas das mudanças tecnológicas e organizacionais - em particular, o just in time nas cadeias de produção e distribuição - teriam implicado em maior risco e potencial impacto de greves. Mencionou-se ainda que as redes de informação dentro e fora das organizações também ofereceriam recursos poderosos para mobilização e catalização de reivindicações que podem ou não conduzir a ações coletivas caracterizadas como greves ${ }^{376}$.

Muito se tem falado hoje no fenômeno da mobilidade física e virtual do capital, da produção, de pessoal qualificado e de alguns insumos, de uma nação para outra, como meio de reduzir os custos de mão de obra. Vem se verificando também a formação de gigantescos oligopólios nas mais diversas áreas, capazes de eliminar quem não estiver coligado, o que confirmaria a tese de que os homens de negócios do sistema capitalista não teriam pátria, nem tampouco "face social",377. A dinâmica do processo de terceirização transnacional implica na transferência de pontos de trabalho para nações cuja mão de obra é miseravelmente remunerada como Índia, Malásia e China, e para outros países asiáticos $^{378}$. Esta realidade vem impactando, com particular força, as políticas públicas de fomento à ocupação. Como observou Antonio Rodrigues de Freitas Júnior, a intensificação das interações econômicas ao nível de mercado global torna cada vez mais restrita a capacidade de implementação de projetos sociais distributivos, nos limites dos direitos nacionais, ante a possibilidade de ágil e lícita migração das atividades geradoras de emprego para outras localidades ${ }^{379}$.

\footnotetext{
375 ORGANIZAÇÃO INTERNACIONAL DO TRABALHO. A greve: o direito e a flexibilidade. Brasília: Organização Internacional do Trabalho, 2002, p. 7/10. Na mesma obra, porém em outro capítulo, Oscar Ermida Uriarte questiona "se estamos a caminho de uma 'sociedade pós-conflituosa' ou 'pós-grevista', na qual, pela desideologização, pelo enfraquecimento dos sindicatos e fortalecimento do setor empregador, pela falta de emprego, estar-se-ia gerando, nos trabalhadores, menor propensão para as medidas de luta sindical e diminuição do número e extensão das greves" (Idem, p. 85).

${ }^{376}$ Idem, p. 11.

377 COUTINHO, Grijalbo Fernandes. Terceirização bancária no Brasil: direitos humanos violados pelo Banco Central. São Paulo: LTr, 2011, p. 109.

378 Idem.

${ }^{379}$ FREITAS JÚNIOR, Antonio Rodrigues de. Direito do trabalho na era do desemprego: instrumentos jurídicos em políticas públicas de fomento à ocupação. São Paulo: LTr, 1999, p. 160.
} 
Fenômenos como a adoção do conceito de fábrica flexível e a maior facilidade na migração de trabalhadores reduziram consideravelmente o poder de reivindicação dos trabalhadores em face de seus empregadores.

Em decorrência de todas essas mudanças, vem se observando nos últimos anos o aparecimento de novas modalidades de conflito coletivo ou a revitalização de formas atípicas de greve ${ }^{380}$.

\subsection{GLOBALIZAÇÃO E MOVIMENTO GREVISTA}

A globalização, por sua vez, facilitou bastante a livre circulação de pessoas e de capital, o que também impactou os movimentos paredistas. Até não muito tempo atrás os movimentos grevistas eram organizados sob a sombra do exército de reserva que amedrontava parte dos trabalhadores incutindo neles o temor de uma substituição futura, fazendo com isso que não aderissem à paralisação. Hoje o principal temor já não é a substituição individual dos trabalhadores mais exaltados, mas a mudança das fábricas da atual localização para outra onde a ação sindical é mais branda. É o que observou Ari Possidônio Beltran, ao afirmar que "em tempos de globalização da economia nada impede a fuga de capitais e sua migração de um país para outro, que na visão empresarial mostrese mais conveniente" 381 .

Não é preciso ir muito longe para compreender como a mais fácil mobilidade das empresas vem sendo utilizada como instrumento de combate às ações sindicais. Muito se fala sobre a debandada das montadoras de veículos, que antes concentravam a sua produção no $\mathrm{ABC}$ paulista em razão de sua proximidade com a cidade de São Paulo, maior mercado consumidor de veículos do país, e em razão de lá haver quantidade significativa de mão-de-obra já qualificada para o exercício das funções necessárias, vem optando por se instalar em outros estados. Além da busca por favorecimentos fiscais, esta mobilidade também visaria escapar da ação do combativo sindicato dos metalúrgicos da região ${ }^{382}$. O

380 ORGANIZAÇÃO INTERNACIONAL DO TRABALHO. A greve: o direito e a flexibilidade. Brasília: Organização Internacional do Trabalho, 2002, p. 81.

381 BELTRAN, Ari Possidônio. A autotutela nas relações de trabalho. São Paulo: LTr, 1996, p. 195.

${ }^{382}$ Ao se referir à opção da Volkswagen por permanecer na região do $\mathrm{ABC}$ e não migrar para outros estados, o jornalista Almeida afirmou que "ao contrário dos que fogem do forte sindicalismo do $\mathrm{ABC}$ paulista, Demel acredita na recuperação da região. E já vai colecionando bons resultados: em meio à crise, a Volks aumentou sua liderança no mercado". ALMEIDA, Alvaro Hebert Demelo: "O $\mathrm{ABC}$ tem cura". Istoé independente. 
mesmo movimento de fuga para locais onde as greves sejam mais raras e a ação dos sindicatos mais brandas também se verifica no cenário internacional. $O$ transferência de empresas de um país para outro em busca de menores custos de mão de obra é muitas vezes provocadas pela ação sindical, particularmente pelas conquistas obtidas diretamente pelos trabalhadores por meio da greve, seu principal meio de pressão em busca de atenção para suas reivindicações.

Como salientam Antonio Rodrigues de Freitas Júnior e Lucyla Tellez Merino, deve-se destacar a necessidade de que os argumentos clássicos sejam utilizados com a cautela renovada de situá-los no novo quadro de possibilidades entreabertas (ou reduzidas), pelas mudanças produzidas com a globalização. Isso implica, segundo eles, um tanto mais que apenas o abandono de ortodoxias e dogmatismos, sendo necessário o desafio afirmativo de operar com repertórios conceituais e analíticos continuamente sujeitos a revisão, e abertos à verificação dentro de cenários que tendem a se modificar em velocidade crescente e em direções impreditíveis ${ }^{383}$.

Uma forma de adaptação do direito de greve a nova realidade provocada pela globalização é a realização de uma paralisação que atinja todos os trabalhadores de determinada multinacional em todo o mundo. Para que isto seja possível, é preciso uma ação coordenada dos sindicatos representativos dos trabalhadores em cada um dos países atingidos pela greve, eventualmente coordenada por uma entidade sindical internacional. Deve-se, na medida do possível, observar as exigências estatuídas em cada um dos ordenamentos jurídicos envolvidos.

As dificuldades para a verificação de um movimento deste porte são inúmeras. A principal delas certamente é a dificuldade de articulação conjunta provocada, sobretudo, pela barreira da língua e por outras questões culturais. Cabe mencionar ainda a necessidade de a reivindicação se referir a uma questão do interesse de todos os sindicatos envolvidos

\footnotetext{
Disponível em <http://www.istoe.com.br/assuntos/entrevista/detalhe/31421_O+ABC+TEM+CURA+>. Acesso em 31/11/10. Ari Possidônio Beltran faz ainda menção a uma matéria jornalística publicada na Folha de São Paulo, em 9 de julho de 1995, intitulada "guerra fiscal", asseverando que "no que se refere à disputa entre regiões pela instalação de novas empresas, situação em que o poder administrativo empresarial constitui fator decisivo na escolha e em que são ponderados todos os fatores já mencionados, incluindo a questão da tensão sindical" (Op cit, p. 196)

${ }^{383}$ FREITAS JÚNIOR, Antonio Rodrigues de; MERINO, Lucyla Tellez. Horizontes para o Direito numa sociedade em mudança: dilemas da ALCA, impasses do Mercosul e crise do Estado-Nação como círculo retroalimentador. São Paulo: LTr, 2004, p. 110.
} 
ou de entre eles haver um acentuado elo de solidariedade. A disparidade entre as formalidades exigidas entre os diversos países onde a ação tiver lugar também pode ser um obstáculo. Para superá-lo justifica-se certa maleabilidade na análise dos requisitos para a deflagração da greve nos diversos países envolvidos no conflito.

Uma manifestação de grande proporção assim, embora difícil, não é impossível e já foi verificada em nível comunitário. Um bom exemplo é o do caso que restou conhecido como Viking Line, nome da companhia finlandesa proprietária de um barco batizado de Rosella, transportador de passageiros e de carga que realiza traversia entre Helsink e Tallin. Referida embarcação, vinha operando sob a bandeira finlandesa, contando a tais efeitos com uma tripulação majoritariamente finlandesa até que, em outubro de 2003, decidiu ser registrada na Estonia com a finalidade de fazer uso da mão-de-obra deste país, a quem ela poderia pagar menos e oferecer condições de trabalho inferiores. Comunicou sua decisão à tripulação e à Unitarian Trade Union Federation of Ardèche (FSU), recebendo desta última uma resposta negativa. A FSU declarou que a convenção coletiva do Rosella expirava em 17 de novembro de 2003, anunciando que pretendia ingressar com um conflito coletivo em relação ao caso Rosella a partir de 2 de dezembro, exigindo entre outras questões - que a Viking Line abandonasse sua intenção de repatriar sua embarcação para a Estonia ${ }^{384}$.

Não obstante a legislação finlandesa autorizasse o sindicato a levar a cabo esta medida ao expirar a convenção coletiva que se aplicava ao Rosella, a FSU solicitou à International Transport workers' Federation (ITF), em 6 de fevereiro de 2006 - que informasse todos os sindicatos afiliados acerca dessa situação de conflito, assim como requeresse que eles iniciassem uma ação de solidariedade que consistiria em não negociar nenhum acordo com a Viking Line. Nessas circunstâncias, a ITF, em apoio à FSU, enviou dois dias mais tarde uma circular a todos os filiados, instando-os a não negociar com Viking Line. A empresa reconduziu a situação, desistindo neste momento de mudar o pavilhão de seu barco e postergando sua decisão até 28 de fevereiro de 2005, momento em

\footnotetext{
${ }^{384}$ BASURKO, Olga Fotinopoulou. El asunto Viking Line: um litigio que va más allá de la encrucijada entre las libertades económicas comunitárias y el derecho a la huelga. Tribuna Social: Revista de Seguridad Social y laboral, n. 217, 2009, págs. 43.
} 
que expirava o novo convênio subscrito com a FSU. Apesar do anterior, a ITF não retirou a circular $^{385}$.

Aproximando-se a data em que o novo convênio coletivo expirava, viking Line, prevendo que uma nova tentativa de registrar o Rosella na Estonia iria desencadear uma nova ação coletiva por parte da ITF e da FSU, iniciou em 18 de agosto de agosto de 2004 um procedimento perante a Commercial Court de Londres, solicitando uma resolução judicial declarativa e de condenação (injunction), por meio da qual desejava obter uma ordem compelindo a ITF a retirar a circular, e a FSU a não interferir no seu direito de mudar o pavilhão do Rosella. Enquanto era instruído e julgado o procedimento mencionado, renovou a Convenção Coletiva do Rosella até fevereiro de 2008, o que, em princípio, fazia com que a medida buscada perdesse o seu caráter de excessiva urgência. Ainda assim, em 16 de junho de 2005, a Commercial Court prolatou sentença a favor da empresa, em troca de a Viking Line se comprometer a não despedir nenhum trabalhador como consequência da mudança de seu pavilhão. Em 30 de junho de 2005, a ITF e a FSU interpuseram recurso de apelação perante à Court of appeal (England and Wales - civil division), órgão judicial que - diante da complexidade do caso - apresentou em 03 de novembro de 2005, dez questões prejudiciais perante o Tribunal de Justiça da Comunidade Européia, que se encerraram com a sentença de 11 de dezembro de $2007^{386}$.

A sentença em questão ponderou, em seu considerando 89, que a ITF, quando um de seus membros solicita, está obrigada a iniciar uma ação de solidariedade contra o proprietário efetivo de uma embarcação registrada em um Estado distinto do Estado de que é nacional esse proprietário, independentemente de o exercício por este último de seu direito ao livre estabelecimento poder ou não ter consequências prejudiciais sobre o emprego ou sobre as condições de trabalho de seus assalariados. Considerou, por outro lado, que assim como a Viking sustentou durante a vista, sem que a ITF rebatesse este extremo, a política de reservar o direito de negociação coletiva aos sindicatos do Estado de que é nacional o proprietário efetivo de um barco se aplica também quando o barco está registrado em um Estado que garanta aos trabalhadores uma proteção social maior que a que teriam o primeiro Estado. Olga Basurko, conclui, em sua análise sobre a referida

\footnotetext{
${ }^{385}$ BASURKO, Olga Fotinopoulou. El asunto Viking Line: um litigio que va más allá de la encrucijada entre las libertades económicas comunitárias y el derecho a la huelga. Tribuna Social: Revista de SEguridad Social y laboral, n. 217, 2009, págs. 43.

${ }^{386}$ Ibidem, p. 43.
} 
decisão que, o Tribunal de Justiça da Comunidade Europeia, no caso ora comentado, considerou que a ITF deveria ter sido mais prudente na hora de ditar uma circular iniciando uma ação de solidariedade com o objeto restringir ou limitar o exercício das liberdades econômicas comunitárias da Viking Line, dado o denominado efeito direto horizontal das mesmas sobre as ações coletivas. E concluiu com a seguinte crítica: "el asunto Viking Line há supuesto un enorme respaldo por parte del TJCE al desenvolvimiento de las libertades económicas comunitárias cuando éstas se contraponen a los derechos colectivos de los trabajadores y sus representantes ${ }^{387}$,"

Em outro interessante ensaio, Olga Fotinopoulou Basurko destaca que o artigo 9 do Tratado Roma II estabelece as regras conflituais aplicáveis à ação de conflito transnacional conectada com mais de um ordenamento jurídico, estabelecendo alguns critérios de conexão. Primeiramente a lei aplicável à obrigação extracontratual será a que as partes determinarem, de acordo com o disposto no artigo 14 do aludido tratado, já que o artigo 9 não exclui a sua aplicação. Não sendo possível, por alguma razão, essa solução, aplicar-seá o disposto no artigo 4.2 que estabelece como critério de conexão a lei da residência comum das partes. Se nenhuma destas hipóteses for possível, a determinação da lei aplicável às obrigações extracontratuais derivadas de um conflito coletivo se submeterá à lei do país em que houver ocorrido a ação ou a daquele em que ela irá ocorrer ${ }^{388}$.

\subsection{TERCEIRIZAÇAO E MOVIMENTOS GREVISTAS}

Cabe, em particular, falar da terceirização, técnica administrativa que possibilita o estabelecimento de um processo gerenciado de transferência, a terceiros, das atividades

\footnotetext{
${ }^{387}$ BASURKO, Olga Fotinopoulou. El asunto Viking Line: um litigio que va más allá de la encrucijada entre las libertades económicas comunitárias y el derecho a la huelga. Tribuna Social: Revista de SEguridad Social y laboral, n. 217, 2009, p. 58. Sobre o mesmo tema ver também: RODIÈRE, Pierre. Les arrêts Viking et Laval, le droit de grève et le droit de négociation collective. Revue trimestrielle de droit européen, 2008, n. 1, p. 47. Nele se afirma que "Le droit de grève doit être reconnu en tant que droit fondamental faisant partie des príncipes généraux du droit communautaire. Mais son exercice devra être concilie avec les libertés d'établissement et de prestation de services qui constituent des príncipes fondamentaux de la Communauté et peuvent être invoques directement em justice à l'encontre d'um syndicat. Le droit communautaire peut s'opposer, au nom de la liberte de prestation de servisse, à une action de grève dont l'objet est de faire appliquer une convention collective de l'Etat d'accueil à des travailleurs détachés".

${ }_{388}$ BASURKO, Olga Fotinopoulou. Las Responsabilidade del sindicato em huelgas transnacionales (segunda y última parte). Tribuna Social: Revista de Seguridad Social y laboral, n. 239, 2010, p. 39.
} 
acessórias e de apoio ao escopo das empresas que é a sua atividade-fim, permitindo-lhes se concentrar em seu negócio ${ }^{389}$.

Aludida prática veio para o Brasil acompanhada de muita polêmica. Jorge Luiz Souto Maior chega a afirmar que a terceirização, da forma como disciplinada no Brasil, significou uma espécie de "legalização" da redução dos salários e da piora das condições de trabalho dos empregados. Os trabalhadores deixam de ser considerados empregados das empresas onde há a efetiva execução dos serviços e passam a ser tratados como empregados da empresa que fornece mão-de-obra, com óbvia redução dos salários que lhes eram pagos, o que permite ainda, segundo pondera Souto Maior, nova redução cada vez que se altere a empresa prestadora dos serviços, sem que haja, concretamente, solução de continuidade dos serviços executados pelos trabalhadores ${ }^{390}$.

Direcionando a discussão para o tema deste trabalho, é forçoso reconhecer, acompanhando entendimento adotado por Mário Rusciano, que a terceirização da economia é acompanhada da terceirização do conflito. Uma mudança que está fragmentando gravemente os interesses coletivos, desarticulando as instituições e a ação sindical. Transformações enormes, fruto de reações em cadeia, das qual nasceu um verdadeiro e novo modelo econômico que domina a vida de todos nós: violentos ou não violentos $^{391}$.

Grijalbo Fernandes Coutinho observa hoje ser cada vez mais comum a repartição do processo produtivo em vários núcleos pequenos, quebrando o sentido de homogeneidade da classe trabalhadora. Se organizar milhares de trabalhadores numa mesma base já não é tarefa das mais fáceis, muito mais complexo é conseguir uni-los quando já estão separados de maneira conceitual e física. A terceirização agravaria esse quadro a partir do rompimento do vínculo laboral com a empresa matriz, que consegue arranjar outra pessoa jurídica para cuidar das tensões sociais de sua alçada, o que imporia verdadeira clausura às reivindicações de natureza trabalhista. Ainda mais nefasto do que o notório rebaixamento salarial dos empregados das empresas terceirizadas, é, em sua opinião, o golpe que representa à organização coletiva dos trabalhadores, reduzindo todos e

\footnotetext{
${ }^{389}$ QUEIROZ, Carlos Alberto Ramos Soares de. Manual de terceirização. $7^{\mathrm{a}}$ ed. São Paulo: STS, 1994, p. 31.

${ }^{390}$ MAIOR, Jorge Luiz Souto. Curso de direito do trabalho: a relação de emprego, volume II. São Paulo: LTr, 2008, p. 145.

${ }^{391}$ RUSCIANO, Diritto di sciopero e assetto costituzionale. Rivista italiana di diritto del lavoro, 2009, I. G, p. $49-69$, p. 55.
} 
não apenas os terceirizados a meros reprodutores do sistema com voz reivindicatória incapaz de produzir resultados mínimos e satisfação real obreira, enquanto classe antagônica ao capital ${ }^{392}$.

A legislação brasileira de greve não faz menção expressa à palavra terceirização. A lei tampouco pareceu contemplar esta estratégia de gestão empresarial ao definir greve como "a suspensão coletiva, temporária e pacífica, total ou parcial, de prestação pessoal de serviços a empregador". Ao usar a expressão empregador, o legislador abriu espaço para que se considerasse a greve dos terceirizados ilícita por contemplar a paralisação da prestação de serviços a quem tecnicamente não é o empregador, mas o seu cliente, o tomador de seus serviços.

Esta interpretação demasiadamente restritiva não pode, contudo, prosperar. A uma porque em se tratando de trabalhador terceirizado a única forma possível de deixar de atender as determinações de seu empregador é deixando de prestar serviços ao tomador. A duas porque o entendimento em questão deixaria os empregados de empresas terceirizadas sem condições de realizar movimentos grevistas, o que não se coaduna com o que preceitua o artigo $9^{\circ}$ da Constituição da República.

Outra questão complexa relacionada com a paralisação das atividades dos trabalhadores terceirizados diz respeito à eventual interferência desta paralisação na prestação de serviços dos empregados da empresa tomadora. Havendo relação de dependência entre as atividades dos trabalhadores terceirizados e as dos empregados diretamente contratados, poder-se-ia considerar que a paralisação daqueles violaria o direito destes ao trabalho.

Imagine-se o exemplo de trabalhadores de uma empresa de logística que atuam em uma montadora e decidem paralisar suas atividades, que vão desde as manobras de pátio até a entrega nas concessionárias, impedindo, com isso, o escoamento da produção de veículos. Em razão do acúmulo de automóveis no pátio, os empregados da montadora são instados a paralisar suas atividades, pois não haverá como nem para onde deslocar a nova produção.

392 COUTINHO, Grijalbo Fernandes. Problemas atuais e perspectivas para o mundo do trabalho. In: PAIXÃO, Cristiano; RODRIGUES, Douglas Alencar; CALDAS, Roberto de Figueiredo (coords.). Os novos horizontes do direito do trabalho: homenagem ao ministro José Luciano de Castilho Pereira. São Paulo: LTr, 2005, p. 303/304. 
Haveria neste caso violação ao direito dos empregados da empresa tomadora de serviços ao trabalho? Evidentemente não. Os trabalhadores terceirizados não impediram, com a sua paralisação pacífica, os empregados da empresa tomadora de serviços de trabalhar. Se não puderam fazê-lo foi em razão da complexa estrutura empresarial escolhida por seu empregador apresentar um vínculo de autodependência tão acentuado entre diversos setores que a paralisação das atividades de uma das contratadas interfere em toda sua produção. E como é o empregador quem assume os riscos da atividade econômica, deverá ele arcar com o pagamento dos dias em que seus empregados estiveram a sua disposição, mas não puderam trabalhar em razão da paralisação na prestação de serviços por outra empresa.

Ademais, a relação entre a empresa tomadora de serviços e a empresa prestadora de serviços é uma relação comercial, cível. Ela não fica impossibilitada de rompimento em razão da paralisação do cumprimento contratual em decorrência da greve dos empregados desta. Nada impede, portanto, que o tomador de serviços contrate outra para substituir aquela que teve a sua prestação paralisada, o que, em verdade, deveria ser um motivo a mais, talvez o mais intransponível, para a empresa prestadora de serviços negociar habitualmente e com bastante transparência e boa-fé com os seus empregados. Afinal, a perda deste contrato não é favorável a nenhuma das partes envolvidas nesta relação capitaltrabalho.

Não sendo assim, as empresas prestadoras de serviços com esta peculiadade sempre poderão utilizar o argumento de prejuízo ao direito ao trabalho dos empregados da tomadora para frustrar os movimentos organizados por seus trabalhadores, o que além de não ser justo é inconstitucional. O prejuízo do empresário tomador dos serviços terceirizados e a paralisação dos seus empregados diretos servem para o empregador prestador de serviços terceirizados, pois viram argumento para que este obtenha um pronunciamento acerca da ilicitude da greve.

Prevalecendo a tese de que a paralisação dos trabalhadores terceirizados não tem relação alguma com o tomador que fica, portanto, liberado, salvo disposição contratual em contrário, para rescindir o contrato em razão do inadimplemento da empresa prestadora, os mesmos fatores acabam servindo ao movimento grevista, como mais um elemento de pressão. Receoso de que o prejuízo do empresário tomador dos serviços terceirizados e a 
paralisação dos seus empregados diretos o leve à rescindir o contrato comercial, o empregador prestador de serviços terceirizados não terá outra alternativa a não ser negociar com os grevistas, atendendo as suas reivindicações.

Em situações como esta a terceirização que hodiernamente é tão maléfica aos movimentos paredistas poderá servir-lhe como instrumento de pressão. É preciso, contudo, ressalvar, que, como em toda negociação, a boa-fé, o bom senso e a razoabilidade são imprescindíveis para que se chegue a algum lugar. Se os grevistas levarem este poder de pressão ao extremo, sem atentar para eventuais limitações do empregador, acabarão provocando a rescisão do contrato e uma dispensa coletiva que não interessa nem ao capital nem ao trabalho.

\subsection{REVOLUÇÃO TECNOLÓGICA E MOVIMENTOS PAREDISTAS}

Segundo Grijalbo Fernandes Coutinho, a revolução tecnológica enfrentada nas três últimas décadas foi capaz de produzir avanços científicos tão fantásticos quanto devastadores pra o mundo do trabalho, deixando, segundo dados da OIT, pelo menos 1 (um) bilhão de desempregados no mundo. Indica o autor que o uso da microeletrônica e de outros recursos fizeram com que algumas tarefas fossem absorvidas por esse novo processo produtivo, reduzindo-se a utilização da mão-de-obra humana e dizimando-se alguns postos de trabalho. Diante da falta de embaraços para incrementar novos meios de produção, passando da forma taylorista-fordista de organização da produção para o modelo digital-toyotista, de viés essencialmente automatizado, dirigido apenas para fatias específicas de consumidores e limitado à demanda imediata, com a substituição de grandes fábricas por empresas de rede ${ }^{393}$.

Oscar Ermida Uriarte destaca que a automação é, indiscutivelmente, um dos efeitos centrais das novas tecnologias sobre a produção e o trabalho, por permitir que os processos de produção funcionem quase sós, quase sem trabalhadores. Apresenta como seus efeitos mais notórios a ineficácia da interrupção total do trabalho, própria da forma tradicional do exercício da greve e o fato de esta suspensão afetar a terceiros, especialmente a opinião

393 COUTINHO, Grijaldo Fernandes. Problemas atuais e perspectivas para o mundo do trabalho. In: PAIXÃO, Cristiano; RODRIGUES, Douglas Alencar; CALDAS, Roberto de Figueiredo (coords.). Os novos horizontes do direito do trabalho: homenagem ao ministro José Luciano de Castilho Pereira. São Paulo: LTr, 2005, p. 112/113. 
pública e o consumidor, em seus dizeres "cada vez mais reacionários, egoístas, alienados, frívolos, pós-modernos, que reagem imediatamente contra a greve que os priva de seus objetos de consumo, sem levar muito em conta as causas dessa situação".

Em determinadas atividades econômicas a simples paralisação das atividades dos trabalhadores já não consegue pressionar o empregador como outrora. É o que ocorre, por exemplo, com as instituições financeiras cujo nível de automação das agências possibilita hoje a continuidade da maioria dos seus serviços através da rede mundial de computadores, dos terminais de autoatendimento e dos correspondentes bancários, ainda que haja paralisação de todos os trabalhadores das agências. Os clientes não sentem diretamente os efeitos do direito de greve e, em razão disso, o movimento fica fadado ao fracasso.

Possivelmente em atenção a esta constatação algumas legislações já determinam a paralisação de todas as atividades dos estabelecimentos correspondentes aos trabalhadores manifestantes. No Chile, por exemplo, diferentemente do que estava previsto no Código de 1931, o artigo 33 da Lei n. 16.625 estatui que, uma vez declarada a greve serão suspensas todas as atividades da empresa ou prédio correspondente ao pessoal em conflito. Excetuam-se desta regra apenas os trabalhos de imprescindível necessidade destinados à conservação de frutos, plantações e animais, aos quais deverão se voltar o pessoal de emergência. Um inspetor do trabalho será designado para fiscalizar esses trabalhadores e conferir se, efetivamente, eles estão se dedicando exclusivamente a estas atividades. Enquanto durar a greve o empregador não poderá, em nenhum caso, retirar do prédio correspondente ao pessoal em conflito, animais, máquinas e produtos, salvo os perecíveis $^{394}$.

A percepção de que a suspensão, ainda que total, das atividades perde eficácia e cria resistências, aliada a inevitável constatação de que vivemos numa sociedade e em uma época em que o maior patrimônio de uma empresa é a sua imagem perante o consumidor, ou seja o valor de sua marca, tem levado à criação de novas modalidades de conflito coletivo, reformulação de outras, adaptadas ao novo cenário.

Oscar Ermida Uriarte fornece interessantes exemplos de movimentos grevistas adaptados a esta nova realidade. Ele cita em primeiro lugar a chamada greve japonesa ou

\footnotetext{
${ }^{394}$ ARTEAGA, William Thayer e FUENZALIDA, Patricio Novoa. Manual de derecho del trabalho, tomo I, Generalidades, Derecho Colectivo del trabajo. 5a edición. Santiago: 2007, p. 174.
} 
greve à japonesa, caracterizada pela utilização de lenços braceletes ou distintivos, como forma de exteriorizar a situação, especialmente por parte do pessoal em contato com o público. Refere-se ainda às concentrações, marchas ou manifestações que vêm sendo reformuladas e adaptadas para atingir a imagem da outra parte perante a opinião pública. A este respeito comenta a falta de razão para se realizar piquetes de massa diante da sede da empresa, mas em locais com maior apelo ao público ${ }^{395}$.

Os exemplos concretos também são bastante elucidativos. $\mathrm{Na}$ Argentina professores instalaram uma "tenda docente" diante do Congresso e a mantiveram durante quase três anos, até 31 de dezembro de 1999, para afetar a imagem do governo e das autoridades da educação sem, contudo, alterar a normalidade dos cursos. No Uruguai o corpo de balé fez, em 1999, apresentações públicas numa praça central de Montevidéu, como medida de conflito. A orquestra sinfônica municipal de Santiago do Chile executou diversas peças, algumas sérias, outras notoriamente irreverentes, cômicas ou burlescas diante da Prefeitura ${ }^{396}$.

A cidade Santiago no Chile também foi palco de outras manifestações dignas de menção. Ermida Uriarte menciona episódio em que um número expressivo de aeromoças de determinada companhia aérea compareceu impecavelmente vestida em seus elegantes uniformes, porém encapuzadas ${ }^{397}$. Essa situação se assemelha bastante com a ocorrida na cidade de Curitiba em 1995, quando, para escapar aos riscos da greve, carteiros optaram por raspar suas cabeças para protestar contra os baixos salários ${ }^{398}$.

É preciso, contudo, reconhecer a possibilidade de a automação e informatização da produção e da gestão abrirem um novo espaço para a ação conflitiva. Como bem observa Ermida Uriarte, a obstrução do funcionamento normal da empresa, pode realizar-se agora de outras formas, caso se conheçam bem as técnicas. $\mathrm{O}$ autor uruguaio exemplifica citando a denominada cibergreve dos trabalhadores de determinada empresa do setor petrolífero francês, realizada em 1999, em que se fez uso bem sucedido da informática para obstrituir a produção e difundir o conflito. A greve foi desencadeada pela classe operária contra um programa de redução de 1500 postos de trabalho no ramo de exploração e produção da

\footnotetext{
395 ORGANIZAÇÃO INTERNACIONAL DO TRABALHO. A greve: o direito e a flexibilidade. Brasília: Organização Internacional do Trabalho, 2002, p. 98.

${ }^{396}$ Ibidem

${ }^{397}$ Ibidem, p. 99.

398 VIANA, Márcio Túlio. Direito de resistência: possibilidades de autodefesa do empregado em face do empregador. São Paulo: LTr, 1996, p. 318.
} 
empresa. Em determinado momento do conflito, trabalhadores altamente qualificados, reunidos em outro sindicato, entraram em greve parcial de duas horas de duração, bloqueando todo o sistema informático da empresa, que parou literalmente. Simultaneamente criou-se um sítio na rede mundial de computadores destinado às filiais do grupo econômico, à imprensa e aos demais interessados no conflito ${ }^{399}$.

\subsection{PRIMAZIA DA PREOCUPAÇÃO COM O CONSUMIDOR}

Márcio André Medeiros Moraes pondera que "independentemente de classe social, todos consomem bens e utilizam serviços, cada um dentro da sua realidade e possibilidade" ${ }^{\natural 00}$. Thierry Bourgoignie vai ainda mais além e afirma textualmente que todo mundo é levado a consumir e todos são consumidores ${ }^{401}$. Sendo certo que todo trabalhador é um consumidor e que a maioria dos consumidores são trabalhadores, é forçoso reconhecer a interligação entre o direito do consumidor e o direito do trabalho ${ }^{402}$.

Demais disso, como bem observa Márcio André Medeiros, "há uma preocupação mundial com o consumidor, sendo comum associá-lo à figura do trabalhador. Eles estão muito próximos, ambos são considerados hipossuficientes" ${ }^{\natural 03}$. No primeiro caso ele é presumidamente hipossuficiente em relação ao empregador. No segundo em relação ao produtor ou fornecedor. Em ambas as situações eles necessitam, por esta razão, de um espírito coletivo, aglomerando-se em grupos da mesma categoria, com objetivos comuns, visando com isso unir esforços em prol de fins maiores.

O paradoxo dos tempos atuais é que não obstante o direito do consumidor tenha se desenvolvido espelhado no caráter protecionista do direito do trabalho vem se verificando, cada vez com maior força, certa supervalorização da figura do consumidor. É bastante conhecido a este respeito o adágio segundo o qual, "o cliente tem sempre razão". Herman Benjamim coloca-o no centro de toda a cadeia produtiva e, sob certo aspecto, da de

\footnotetext{
${ }^{399}$ Ibidem, p. 99.

${ }^{400}$ MORAES, Márcio André Medeiros. A responsabilidade civil do sindicato perante o consumidor. 2001. 377 f. Tese (doutorado em Direito das Relações Sociais - Direito Civil). Pontíficia Universidade Católica de São Paulo, São Paulo, 2001, p. 9.

${ }^{401}$ BOURGOIGNIE, Thierry. Élements pour une theórie du droit de la consummation. Bruxelles: Story scientie, 1988, p. 41.

${ }^{402}$ Em interessante estudo, Gilberto Carlos Maistro Junior dissertou sobre a utilização do Código de Defesa do Consumidor como principal fonte subsidiária do dirieto do trabalho. MAISTRO JUNIOR, Gilberto Carlos. O Código de Defesa do Consumidor como principal fonte subsidiária diante das lacunas na legislação trabalhista. Revista Bonijuris, abril 2011, ano XXIII, n. 569, v. 23, n.4.

${ }^{403}$ Op cit, p. 10.
} 
serviços ao afirmar que "é para ele e pensando nele que se produz. É a ele que se vendem produtos e serviços; é a ele que se busca seduzir com a publicidade. É o consumidor, enfim, quem paga a conta da produção e é dele que vem o lucro do produto" ${ }^{\text {404 }}$.

Ora, sendo certo que a maioria dos consumidores, em termos quantitativos e não qualitativos, é composta por empregados e trabalhadores informais e não por empresários e que "não se pode negar que é o consumidor quem paga a conta da produção e que o lucro do produto provém dele ${ }^{, 405}$, há que se reconhecer que o papel dos trabalhadores na relação de produção não se limita apenas à utilização de sua força de trabalho, abrangendo também a sua capacidade de consumir produtos que ele direta ou indiretamente ajuda a produzir. E como salientou Márcio André Medeiros Moraes, "O consumo não deve ser dissociado da renda. O aumento do poder aquisitivo dos salários supõe a produção, já que os trabalhadores aumentarão o consumo de bens e serviços" "406. Arrematando que "É inconteste que uma boa política salarial aumenta o poder aquisitivo dos trabalhadores, e, por via de consequiência, esses passam a comprar mais" ${ }^{407}$.

$\mathrm{O}$ ponto de distanciamento entre a figura do trabalhador e a do consumidor, quando reunidas na mesma pessoa, se verifica no momento em que a opção do trabalhador por exercer o seu direito de greve prejudica os interesses do consumidor. É o que ocorre, por exemplo, quando o empregador-fornecedor repassa para o consumidor, categoria na qual se inserem muitas vezes os próprios empregados, o prejuízo causado por uma paralisação prolongada, através de aumento nos preços. É o que ocorre também quando empregados de determinada categoria econômica ao se sentirem prejudicados pela paralisação de trabalhadores de outra categoria, em especial a daqueles ligados aos serviços essenciais, ao invés de solidarizarem com estes, independentemente da adesão às chamadas greves de solidariedade, aderem ao coro do empregador em prol da cessação do movimento paredista. Em outras palavras, optam por entrar nas vestes de consumidor e não nas vestes de trabalhador.

404 BENJAMIN, Antonio Herman de Vasconcellos. O conceito jurídico de consumidor. Revista dos Tribunais, vol. 628, n. 77, pp. 69/79, fev. 1988, p. 69.

405 Idem.

${ }^{406}$ MORAES, Márcio André Medeiros. A responsabilidade civil do sindicato perante o consumidor. 2001. 377 f. Tese (doutorado em Direito das Relações Sociais - Direito Civil). Pontíficia Universidade Católica de São Paulo, São Paulo, 2001, p. 19.

${ }^{407}$ Idem 
Após afirmar a fundamentalidade do direito de greve enaltecendo-o como o magno direito coletivo dos trabalhadores, aquele que mais demonstra o caráter de reconhecimento do conflito que há de ser a essência do Direito Sindical, e de destacar o seu caráter sempre polêmico, sempre apaixonante, Antonio Escoteguy Castro faz referência a uma pesquisa publicada na Revista Veja, em fins de 2002, que teria apontado que 38\% dos brasileiros achavam que as greves deviam ser sempre proibidas em qualquer situação ${ }^{408}$.

Parte desta expressiva rejeição dos movimentos grevistas pode ser creditada aos meios de comunicação. Antonio Baylos, analisando a realidade espanhola, mas apresentando considerações que certamente servem bem à realidade brasileira, critica a progressiva hostilidade dos meios de comunicação frente às greves. E ressalta que "el sistema de tutela del derecho de huelga y de la libertad sindical puede verse afectado por las manifestaciones más agressivas de los médios contra las facultades de autotutela colectiva"409. Finaliza afirmando que a informação pública sobre a greve deve ser ponderada e neutra não podendo os meios de comunicação incorrer em formas de manipulação informativa que tergiversem os fatos que sustentam as notícias sobre o conflito, tentando reduzir a incidência da greve ou desestimular a partipação na mesma.

Giovanni Orlandini, defensor da tese da natureza incondicionada do direito de greve, advoga anda a sua prioridade lógica quando posto em confronto com os outros direitos sociais, inclusive com os direitos dos consumidores. Para ele o direito de greve apresentaria prioridade lógica sobre outros direitos sociais, por razões históricas, "dal momento che esso si è imposto prima di questi, su un piano fattuale piuttosto che giuridico, há rappresentato quindi lo strumento di perseguimento di quel principio di eguaglianza sul quale gli altri diritti sociali si fondano, divenendone pré-condizione indispensabile" ${ }^{\text {410 }}$

Aparentemente, entretanto, o que se tem verificado no momento atual é justamente o oposto. A predominância de direitos, como os dos consumidores, sobre os direitos do trabalhador. Aluysio Corrêa da Veiga, Ministro do Tribunal Superior do Trabalho registrou, em obra dedicada ao direito do trabalho e ao processo do trabalho, que "Na

\footnotetext{
${ }^{408}$ CASTRO, Antonio Escosteguy. Trabalho, tecnologia e globalização: a necessidade de uma reforma sindical no Brasil. São Paulo: LTr, 2006, p. 180.

${ }^{409}$ BAYLOS GRAU, Antonio. Estado democrático de derecho y amplio reconocimiento del derecho de huelga. Derecho laboral - tomo LIV, n. 242, abril-junio 2011, p. 292.

${ }^{410}$ ORLANDINI, Giovanni. Sciopero e servizi pubblici essenciali nel processo d'integrazione europea: uno Studio di diritto comparato e comunitário. Torino: Giappichelli editore: 2003, p. 19.
} 
greve dos bancos, por exemplo, a maior preocupação se dá, de fato, com os clientes” ${ }^{411}$. Também manifestando maior preocupação com a situação dos trabalhadores do que com a situação dos trabalhadores, Márcio André Medeiros Moraes asseverou, ao enfatizar a necessidade de responsabilidade na organização de movimentos paredistas, que:

as conseqüências negativas da explosão de uma greve "descabrestada" atingiria diretamente o consumidor, bem como os fornecedores, abalando a economia do país. E a impunidade seria a regra.

Este tipo de comportamento seria irresponsável, e o coitado do consumidor sofreria injustamente, pois não violou nenhuma norma, nenhum preceito, sofrendo as consequiências negativas de uma greve "descabrestada". Fazse, pois necessária a criação de normas claras e precisas sobre o exercício do direito de greve que deverão ser elaboradas entre os parceiros sociais, mas sempre com a participação de terceiros interessados, pois sofrem os efeitos negativos da greve. Por exemplo, os usuários de serviços e atividades essenciais. Assim, os representantes das associações de consumidores deveriam participar, na hora da elaboração de qualquer acordo concernente às greves, nos setores que lhes afligissem. Essas normas devem ser claras e precisas, evitando-se, assim, abusos no exercício do direito de greve, e que os direitos hierarquicamente superiores, ou no mesmo nível de hierarquia, sejam violados sem a devida punição ${ }^{412}$.

A predominância das preocupações com os consumidores sobre a preocupação com os trabalhadores também transparece da situação vivida por uma empresa aérea brasileira que, no fim das férias de inverno de 2010, precisou cancelar um expressivo número de vôos provocando, com isso, a insatisfação de muitos consumidores e sujeitando-se a elevadas penalidades pecuniárias. A situação apresenta requintes de dramaticidade por se tratar do último final de semana das férias e porque a justificativa apresentada pela empresa expõe um dilema relativamente comum nas grandes corporações, o de ter que escolher entre proteger seus trabalhadores e satisfazer os seus clientes. A assessoria de imprensa da companhia afirmou que o cancelamento dos vôos deveu-se ao fato de não haver funcionários disponíveis porque o número de horas trabalhadas nos últimos tempos superou o limite máximo previsto pela regulamentação da profissão. Ao optar por respeitar

\footnotetext{
${ }^{411}$ VEIGA, Aluysio Corrêa da Veiga. O Direito de greve e o interdito proibitório. In: BOUCINHAS FILHO, Jorge Cavalcanti et ali. $O$ direito material e processual do trabalho dos Novos Tempos: estudos em homenagem ao Professor Estêvão Mallet. LTr, 2009, pp 25/49.

${ }^{412}$ MORAES, Márcio André Medeiros. A responsabilidade civil do sindicato perante o consumidor. 2001. 377 f. Tese (doutorado em Direito das Relações Sociais - Direito Civil). Pontíficia Universidade Católica de São Paulo, São Paulo, 2001, p 108.
} 
as leis trabalhistas, a empresa assumiu uma postura corajosa e pouco usual e sofreu pesadas sanções. A ANAC lhe aplicou multas que superam os R $\$ 2$ milhões de reais ${ }^{413}$. A empresa certamente será ainda condenada a indenizar os consumidores que se sentirem prejudicados e que ingressarem com ação, se já não o houver feito.

Não obstante seja forçoso reconhecer que o problema poderia e deveria ter sido evitado, não se pode deixar de atribuir à companhia o mérito de ter pensado primeiro nos trabalhadores num contexto socioeconômico em que eles normalmente são os últimos fatores de preocupação. Trata-se de uma decisão sempre difícil. São duas categorias que, em razão de uma presunção de hipossuficiência em relação às empresas, gozam de leis bastante protecionistas, a Consolidação das Leis do Trabalho e o Código de Defesa do Consumidor, respectivamente. Por conseguinte, qualquer das escolhas sempre apresenta graves implicações econômicas.

A relação de trabalho dos aeronautas, contudo, apresenta peculiaridades que certamente pesaram na sua decisão. Os tripulantes apresentam um número máximo de horas a serem trabalhadas por mês porque o seu trabalho apresenta um fator de desgaste a mais, a mudança da pressão atmosférica em razão das constantes subidas e descidas do avião. Demais disso, falhas decorrentes de erros humanos provocados pelo cansaço são, no caso dos pilotos, simplesmente catastróficas. Elas colocam em risco a vida de todos os passageiros e das pessoas que vivem nas imediações dos locais por onde o avião trafega. Pode-se, com isso, afirmar que a decisão visou preservar a segurança dos empregados e também a dos consumidores, embora estes a tenham recebido contrariados em razão de o seu interesse imediato não ter sido atendido.

A empresa foi punida pela sua falta de planejamento. Mas, acertou ao, diante do dilema criado pela falta de planejamento prévio, tomar a pouco usual decisão de colocar seus trabalhadores antes de seus clientes, assumindo, assim, diversos ônus econômicos e enfrentando significativo desgaste à sua imagem para garantir a segurança dos integrantes das duas categorias.

Diversa, entretanto, foi a preocupação demonstrada durante o movimento grevista dos aeroviários no final do ano de 2010 em que se pôs em confronto interesses de

${ }^{413}$ GONÇALVES, Glauber. Anac multa gol em R $\$ 2$ milhões por atrasos e cancelamentos de vôos. O Estado de São Paulo. Disponível em: <http://www.estadao.com.br/noticias/cidades,anac-multa-gol-em-r-2-milhoespor-atrasos-e-cancelamentos-de-voos,590360,0.htm>. Acesso em 25/12/2011. 
trabalhadores e de consumidores. Diante da resistência das empresas em aceitar o reajuste salarial de $13 \%$ a $30 \%$, conforme a faixa salarial, a categoria organizou-se para realizar um movimento paredista durante as festividades de fim de ano, o que, indiscutivelmente, afetaria os consumidores de serviços aéreos. Esta situação claramente colocou em confronto o direito dos trabalhadores grevistas de reivindicar melhorias salariais com o direito de diversas outras categorias de trabalhadores à livre locomoção do território nacional durante as festas de fim-de-ano. Para impedir que a paralisação em questão provocasse novo "caos aéreo" foram ajuizadas três ações coletivas, em três esferas judiciárias distintas. O Ministério Público do Trabalho pleiteou junto ao Tribunal Superior do Trabalho (TST) provimento liminar em ação cautelar preparatória de dissídio de greve que obrigasse $80 \%$ dos aeroviários e aeronautas a trabalharem normalmente do dia 22 de dezembro até o dia 3 de janeiro. A multa diária em caso de descumprimento seria de $\mathrm{R} \$$ 100 mil. A Advocacia Geral da União, por sua vez, pediu ao Tribunal Regional do Trabalho que assegurasse, mediante decisão judicial, a continuidade das atividades de pelo menos $90 \%$ dos funcionários até o dia 7 de janeiro, sob pena de multa diária de $\mathrm{R} \$ 500$ mil. Por fim, o Ministério Público Federal pleiteou a manutenção integral das atividades da categoria dos aeronautas e aeroviários sob pena de multa diária de $\mathrm{R} \$ 3$ milhões de reais.

A $4^{\mathrm{a}}$ Vara Federal do DF acolheu o pleito do Ministério Público Federal determinando que os sindicatos dos aeronautas (pilotos e comissários) e dos aeroviários (funcionários que trabalham em terra) garantissem que $100 \%$ dos trabalhadores mantivessem suas atividades, sob pena de multa diária de $\mathrm{R} \$ 3$ milhões. Em sua decisão evidenciou a superposição de sua preocupação com os consumidores sobre o direito dos trabalhadores de reinvindicar melhores condições de trabalho. Segundo artigo divulgado na rede mundial de computadores, o prolator da sentença teria consignado que "a deflagração de movimento paredista neste momento, às vésperas das festividades de final de ano e posse de Presidente da República, governadores de estados e membros dos poderes Legislativos Federal e Estaduais afigura-se oportunista e abusiva" ${ }^{414}$. De acordo com a mesma matéria, o Procurador da República Bruno Calabrich teria afirmado que a ação por ele ajuizada não estaria questionando o direito dos profissionais de transporte aéreo de reivindicar melhores condições de trabalho, mas a impossibilidade de se admitir que "o direito de milhares de brasileiros - e não só passageiros - seja utilizado como moeda de 
troca nessas reivindicações" ${ }^{415}$. As assertivas do magistrado e do representante do parquet federal evidenciam a influência dos direitos do consumidor na forma de analisar e de se interpretar hodiernamente o direito de greve.

Aludidas ações refletem o amplo temor que se espraiou por uma parcela significativa da população nacional. Milhares de trabalhadores de outras categoriais que haviam adquirido bilhetes aéreos para o período natalino de 2010, receosos de não poder desfrutar das festividades como haviam imaginado e, pensando, portanto, como consumidores, ao invés de se solidarizarem com a categoria dos aeronautas e dos aeroviários, assumiram opinião contrária à greve, enaltecendo a sua abusividade. Esta postura naturalmente foi muito bem explorada pelos empregadores do setor que utilizaram o prejuízo ao consumidor como principal argumento para colocar a sociedade civil contra os pretensos grevistas. O Sindicado Nacional das Empresas Aéreas (Snea), para se ter uma ideia, disse, em entrevista para matéria veiculada em 17 de dezembro de 2010, não trabalhar com a possibilidade da paralisação porque "Uma greve não levará a nada, além de prejudicar os consumidores, que nada têm a ver com a briga" ${ }^{\natural 16}$.

Esse tipo de postura muito se assemelha à que fora denunciada por Émile Zola na clássica obra Germinal. Em determinada passagem próxima do final da narrativa, o escritor francês descreve o impacto causado pela contratação de trabalhadores belgas para substituir os locais, franceses, que haviam paralisado suas atividades. Com a contratação dos belgas o empregador conseguiu tirar o foco das manifestações de si e direcioná-los para os estrangeiros que haviam sido contratados para substitui-los. A revolta dos grevistas, que antes tinham como alvo o empregador, for direcionada para outros trabalhadores $^{417}$.

\footnotetext{
415 RECONDO, Felipe. Disponível em <http://estadao.br.msn.com/ultimas-noticias/artigo.aspx?cpdocumentid=26882183 $>$. Acesso em 24/12/10. 416

<http://www.correiobraziliense.com.br/app/noticia/economia/2010/12/17/internas_economia,228170/grevede-aeroviarios-e-aeronautas-deve-trazer-longas-filas-na-quinta-23.shtml>. Último acesso em 16/12/2011.

${ }^{417}$ É o que bem retrata a seguinte passagem da obra: "D'un air de gêne, Étienne expliqua qu'on ne pourrait pas bouger, que les soldats qui gardaient les fosses protégeraient la descente des ouvriers belges. Et Maheau serrait les poings, irrité surtout, comme il disait, d'avoir ces baïonnettes dans le dos. Alors, les charbonniers n'étaient plus les maîtres chez eux? On les traitait donc en galériens, pour les forcer au travail, le fusil chargé? Il aimait son poutis, ça lui faisait une grosse peine de n'y être pas descend depuis deux mois. Aussi voyait-il rouge, à l'idée de cette injure, de ces étrangers qu'on menaçait d'y introduire. Puis, le souvenir qu'on lui avait rendu son livret lui creva le coeur". (ZOLA, Émile. Germinal. Ebook. Maio, 2004, p. 522 de 709).
} 
Quando se está diante de uma supervalorização do direito do consumidor o resultado para o movimento grevista é bastante similar. Ao ver o seu direito enquanto consumidor ameaçado, os trabalhadores de outras categorias ficam contra os grevistas porque preferem ver o seu direito restabelecido, o que muitas vezes implica em se alinhar, ainda que apenas em discurso verbal, com os empregadores, a abrir mão momentaneamente de seu conforto ou de uma necessidade postergável para se solidarizar com outros trabalhadores.

Essa supremacia do direito do consumidor ao direito do trabalho não se afigura adequada. Conquanto não se possa deixar de reconhecer a importância dos direitos consumeristas é forçoso reconhecer que a condição de trabalhador sempre precede a de consumidor. Afinal a maioria da população consome com a contraprestação pecuniária recebida para o seu trabalho. O predomínio do entendimento de que os consumidores não podem ser prejudicados pelas reivindicações dos trabalhadores conduzirá ao fim do direito de greve, o que não pode ser admitido.

Como bem observou Paulo Garcia, é errado afirmar que ao fazer greve o operariado tenha como finalidade prejudicar a produção capitalista. Essa finalidade não existe e o operariado jamais quis prejudicar a produção ou outra coisa qualquer. Deseja apenas não ser ele o sacrificado. Quando pede melhores condições de trabalho ou salários mais elevados, não se pode dizer que com isso esteja querendo prejudicar a produção capitalista. Se o patrão atender seu pleito aumentando os salários ou melhorando suas condições de trabalho, nem sequer haverá greve, porque o objetivo do trabalhador, que era apenas a obtenção de uma determinada vantagem, foi satisfeito ${ }^{418}$.

O Direito de Greve, enquanto instrumento democrático que viabiliza que os atores sociais solucionem seus conflitos diretamente, sem precisar da intervenção de um terceiro, pressupõe uma espécie de contrato social em que todos admitam sacrificar seus direitos e interesses em determinados pontos em prol de um interesse coletivo maior. Por meio deste contrato trabalhadores de categorias não envolvidas na reivindicação se predispõe a abdicar de seus direitos enquanto consumidores para que outros possam coletivamente reivindicar os seus, na expectativa de reciprocidade quando chegar o seu momento de lutar por melhores condições de trabalho. Os empresários, os empregadores em geral, admitem

${ }^{418}$ GARCIA, Paulo. Direito de greve. Rio de Janeiro: Edições trabalhistas s.a, 1961, p. 10. 
prejuízos pontuais ao seu empreendimento e eventualmente aos seus direitos enquanto consumidores para poder viabilizar um modelo em que possam negociar coletivamente a solução para os conflitos que os atingirem e estabelecer condições de trabalho sem precisar do auxílio estatal. Não é demais lembrar, como bem o faz Otavio Pinto e Silva, que somente se pode falar em contratação coletiva como fonte do direito do trabalho quando o ordenamento jurídico efetivamente garantir o direito de greve ${ }^{419}$.

Oscar Ermida Uriarte enfatiza a funcionalidade do conflito de trabalho nas relações industriais. A greve cumpre, em sua opinião, uma função equilibradora, absolutamente indispensável para que as relações de trabalho - em particular, a negociação coletiva sejam possíveis com um mínimo de equilíbrio de forças ${ }^{420}$.

Dentro desta concepção funcional, o conflito não é uma patologia, mas um fenômeno natural ou normal, inclusive necessário, que extrapola o campo do direito do trabalho e das relações de trabalho, instalando-se nas concepções atuais da filosofia e da ciência política, de um lado, e das ciências físicas, de outro. Segundo Ermida Uriarte, "a especificidade da democraria consiste, hoje, na legitimação do conflito e na recusa de eliminá-lo pela incorporação de uma ordem autoritária, a partir do reconhecimento natural e inevitável do pluralismo constitutivo da ordem democrática"421.

Para que este modelo democrático, que valoriza a solução autocompositiva dos conflitos coletivos de trabalho e tem na greve o seu mais importante instrumento pra alcançá-la, subsista é preciso que todos se disponham a aceitar privações em seus direitos do consumidor ou a enfrentar determinados prejuízos. Não sendo assim, melhor será abrir mão dele e retornar para um sistema em que a solução é oriunda sempre do Estado, como já se viu no Brasil há algum tempo.

Também se verifica entrelaçamento entre o direito do trabalho e o direito do consumidor quando se utiliza a estratégia do boicote como meio de pressionar o empregador. Neste caso, o consumidor acaba sendo um útil aliado do trabalhador, auxiliando-o a pressionar o empregador a atender suas reivindicações.

\footnotetext{
${ }^{419}$ SILVA, Otavio Pinto e. A contratação coletiva como fonte do direito do trabalho. São Paulo: LTr, 1998, p. 98.

${ }^{420}$ ORGANIZAÇÃO INTERNACIONAL DO TRABALHO. A greve: o direito e a flexibilidade. Brasília: Organização Internacional do Trabalho, 2002, p. 84.

${ }^{421}$ Ibidem, p. 84.
} 


\subsection{MEIOS COLETIVOS DE PRESSÃO DOS TRABALHADORES E SUA VALIDADE JURÍDICA}

Márcio Túlio Viana observa que a resistência coletiva pode se exercer tanto através de formas homogêneas como de formas heterogêneas de participação de cada indivíduo, como nos casos de greve e de atos variados de sabotagem, praticados por empregados diferentes $^{422}$.

Sem destoar desta afirmação, Oscar Ermida Uriarte observa que o exercício do direito de greve tem se tornado cada vez mais atípico, tanto em seu país, como em todo o mundo, como uma estratégia de maximização do dano e minimização do custo e como estratégia de adaptação flexível do exercício da greve à flexibilização empresarial e produtiva. Neste sentido estariam ganhando importância outras formas de ações coletivas constituídas por comunicados, cartazes, murais ou painéis, emblemas, braceletes, lenços, etc. Igualmente importante seriam atos como declarações públicas, conferências de imprensa, assembleias informativas, silêncio ou barulho num breve espaço de tempo, concentrações internas, piquetes externos, boicote contra o empregador ou outras empresas subprestadoras ou compradoras e a negativa de prestação de horas extras e realização de serviços para diretores da empresa ${ }^{423}$.

Para melhor entender essa interpretação flexível das formas pelas quais é possível se exteriorizar o direito de greve, cabe fazer uso mais uma vez das lições de Márcio Túlio Viana, segundo quem assiste uma parcela de razão àqueles que comparam a greve à guerra. Tanto nesta quanto naquela as partes envolvidas se utilizam de técnicas e táticas variadas para tentar vencer e o fator surpresa é fundamental, o que justifica a exiguidade dos prazos de pré-aviso e a resistência dos sindicatos em cumpri-los. Aludido autor compara ainda a conduta do trabalhador que "fura" a greve à do militar que incorre em deserção. Enfatiza ainda que assim como nas guerras a ação do combatente grevista pode produzir variadas formas de contra-resistência, tanto de caráter repressivo quanto de natureza preventiva. Tal como nas guerras, há os que - sem se arriscar - colhem os frutos da vitória. Escapam das

\footnotetext{
422 VIANA, Márcio Túlio. Direito de resistência: possibilidades de autotutela do empregado em face do empregador. São Paulo: LTr, 1996, p. 282.

${ }^{423}$ ERMIDA URIARTE, Oscar. A greve: o direito e a flexibilidade. São Paulo: LTr, p. 110.
} 
chamadas listas negras e encontram sempre abertas as portas do mercado de trabalho, em flagrante deslealdade com os grevistas ${ }^{424}$.

Ermida Uriarte destaca que uma primeira forma de ação coletiva seria constituída pelos comunicados, cartazes, murais ou pelo uso de painéis, emblemas, braceletes, lenços etc. Em segundo lugar viriam as declarações públicas e conferências de imprensa, seguidas das assembleias informativas, que põe em discussão importantes questões jurídicas, como suas vinculações com o direito dos representantes dos trabalhadores de acesso ao local de trabalho e com o direito de ali se reunirem em assembleias. A quarta forma de manifestação do conflito é o silêncio ou ao seu contrário, o barulho, ambos acertados e concentrados num breve espaço de tempo. Em quinto lugar o autor uruguaio destaca as sentadas, serpentes ou trenzinhos (percursos pelo local do trabalho em filas onduladas formadas por trabalhadores) miniconcrentrações internas etc ${ }^{425}$.

Segundo Amauri Mascaro Nascimento, boicote, de boicotar, significa fazer oposição aos negócios de uma pessoa, de uma classe ou de uma nação. Esta estratégia poder-se-ia se manifestar através da recusa proposital em comprar mercadorias do empregador e na falta de cooperação dos trabalhadores com a produção. A palavra vem de James Boycott, que foi, numa região da Irlanda na segunda metade do século XVIII, latifundiário e teve que abandonar a localidade onde vivia em decorrência de recusa dos trabalhadores de ajudá-lo, negando-lhe toda a colaboração a ponto de ficar marginalizado $^{426}$.

Ermida Uriarte destaca a possibilidade de combinação de greve parcial e boicote como nos casos em que o pessoal que não está em conflito com seu empregador para somente as atividades dirigidas à outra empresa que está, esta sim, em conflito (por exemplo, quando não se despacha mercadoria para ela) ${ }^{427}$.

Os piquetes, segundo Ari Possidônio Beltran, tem como finalidade precípua a exteriorização das intenções do movimento, atuando não só por meio da persuasão dos que

\footnotetext{
${ }^{424}$ VIANA, Márcio Túlio. Direito de resistência: possibilidades de autodefesa do empregado em face do empregador. São Paulo: LTr, 1996, p. 289/290.

${ }^{425}$ ORGANIZAÇÃO INTERNACIONAL DO TRABALHO. A greve: o direito e a flexibilidade. Brasília: Organização Internacional do Trabalho, 2002, p. 88.

${ }_{426}$ NASCIMENTO, Amauri Mascaro. Direito do trabalho na Constituição de 1988. $2^{\mathrm{a}}$ edição. São Paulo: Saraiva, 1991, p. 290.

${ }^{427}$ ORGANIZAÇÃO INTERNACIONAL DO TRABALHO. A greve...op cit, 2002, p. 88/89.
} 
ainda não aderiram, como também procurando obstaculizar o acesso ao recinto de trabalho, por meio de técnicas que vão de simples tentativas de proselitismo da causa, até métodos de pressão morais e mesmo físicos ${ }^{428}$. Amauri Mascaro Nascimento, por sua vez, os define como uma técnica de pressão laboral, normalmente complementar da greve, em que os trabalhadores anunciam à opinião pública o conflito coletivo; tentam dissuadir outros trabalhadores de ingressar no serviço concitando-os à paralisação coletiva ou mesmo usando de violência para impedi-los de trabalhar durante essa ${ }^{429}$.

Em geral eles são formados por grupos que se instalam na entrada do estabelecimento visado pela ação, havendo, também relatos de mass picketing nas proximidades da residência de um fura greve. Os piquetes podem ser de três tipos: coativos ou intimidatórios, quando fazem uso da força física ou da ameaça contra outro empregado ou membros de sua família, sendo comuns também a coação moral, a intimidação e as ofensas verbais; informativos, quando se limitam a fazer publicidade e a informar aos demais empregados as razões e os objetivos do movimento, aguardando que cada um tire suas próprias conclusões e persuasivo quando busca não só a divulgação do movimento, como também apoio para ele $\mathrm{e}^{430}$.

Embora os piquetes sejam usualmente constituídos por um grupo de trabalhadores grevistas, nada impede que a ação do piquete seja executada de forma individual pelo militante. Nos últimos tempos tem se tornado freqüentes os chamados piquetes terceirizados, em que a organização do movimento contrata "terceiros" para fazer a manifestação no lugar dos integrantes da categoria. O principal escopo desta prática é evitar retaliações aos manifestantes. Ela se justifica em um sistema trabalhista destituído de proteção contra a dispensa arbitrária, como é o caso do brasileiro, em que ainda que não sejam permitidas dispensas durante a constância do movimento, não há óbice à formalização delas após o seu término mediante simples pagamento de verbas rescisórias.

Trata-se, portanto, de mais uma solução criativa desenvolvida pelos sindicatos para exercer o direito de pressão coletiva assegurado á categoria por eles representada diante de um novo cenário socio-econômico. Não obstante não esteja expressamente prevista em lei, essa prática não se mostra irregular. O artigo $6^{\circ}$ da Lei 7783/90 assegura aos grevistas,

\footnotetext{
${ }^{428}$ BELTRAN, Ari Possidônio. A autotutela nas relações de trabalho. São Paulo: LTr, 1996, p. 158.

${ }^{429}$ NASCIMENTO, Amauri Mascaro. Direito do trabalho na Constituição de 1988. $2^{\mathrm{a}}$ edição. São Paulo: Saraiva, 1991, p.291.

${ }^{430}$ BELTRAN, Ari Possidônio. Op cit , p. 158.
} 
dentre outros direitos, o emprego de meios pacíficos tendentes a persuadir ou aliciar os trabalhadores nas negociações ou na Justiça do Trabalho, a arrecadação de fundos e a livre divulgação do movimento. A norma não exige que os meios tendentes a persuadir ou aliciar os trabalhadores sejam utilizados diretamente por integrantes da categoria. Abre espaço, outrossim, para que pessoas sejam contratadas para realizar as manifestações com o dinheiro arrecadado dos fundos.

Como salienta Ari Possidônio Beltran, "é consensual, pois, que, como regra, sejam tolerados apenas os chamados piquetes de convencimento, que utilizam meios pacíficos, e que sejam condenadas todas as formas de violência, até as ameaças, invasões ou danos à propriedade ou pessoas" ${ }^{431}$.

Outro meio coletivo de pressão é o rattening, consistente na subtração dos instrumentos de trabalho e dos uniformes com o objetivo de impedir o trabalho daqueles que não aderiram à greve $\mathrm{e}^{432}$. Esta conduta não se encontra chancelada pelo direito de greve na medida em que viola o direito ao trabalho dos não grevistas. Mas não implica no delito no artigo 155 do Código Penal porque a apropriação do objeto não é com intuito de permanecer com ele, tratando-se, portanto, do chamado furto de uso, conduta atípica.

A ocupação do estabelecimento, segundo Ari Possidônio Beltran, consiste em modalidade violenta de ação, que não se coaduna com os princípios do livre jogo democrático atualmente em voga nas relações coletivas de trabalho. Normalmente vem acompanhada de excessos, que empanam o movimento, arrastando-o, frequentemente, para além dos ilícitos civis e trabalhistas e atingindo o enquadramento penal ${ }^{433}$. Surgiu na Itália (1919) com aspectos mais políticos do que trabalhistas, expandindo-se para a França. No Brasil, a Lei n. 4.330, de 1964, no art. 17 dispunha que os empregados iniciariam a greve desocupando pacificamente o estabelecimento, o que leva a supor que essa lei não autorizou a ocupação do estabelecimento ${ }^{434}$. A lei 7.783/89, que a substituiu, nada dispôs a seu respeito, o que pode ser interpretado como um permisso legal para a ocupação do estabelecimento.

\footnotetext{
${ }^{431}$ BELTRAN, Ari Possidônio. A autotutela nas relações de trabalho. São Paulo: LTr, 1996, p. 162.

432 Ibidem.

433 Ibidem, p. 169.

${ }^{434}$ NASCIMENTO, Amauri Mascaro. Direito do trabalho na Constituição de 1988. $2^{\mathrm{a}}$ edição. São Paulo: Saraiva, 1991, p.291.
} 
Segundo Ari Possidônio Beltran o termo boicote, cuja origem remonta a atuação de um adminstrador de terras em um condado na Irlanda chamado Charles Cunningham Boycott ${ }^{435}$, adquiriu conotação bastante ampla passando a significar recusa do público em adquirir determinados produtos ou mercadorias de certos comerciantes e, em tempos de guerras, a recusa de negociação com empresas ou cidadãos de países beligerantes. Trata-se, como se pode facilmente perceber, de hipótese em que novamente a condição de consumidor e de trabalhador passam a apresentar grande interface. Neste caso, o consumidor acaba sendo um útil aliado do trabalhador, auxiliando-o a pressionar o empregador a atender suas reivindicações. Paulo Garcia acertadamente destaca que as atividades de boicote, desde que pacíficas, sempre foram admitirdas como lícitas ${ }^{436}$.

A expressão sabotagem passou, com o decorrer do tempo, a significar ato de violência com o objetivo de danificar máquinas, instalações, produtos, mercadorias e mesmo ferramentas de trabalho ${ }^{437}$. Segundo Paulo Garcia, a sabotagem é bem mais perniciosa que a greve, porque, por ela, além de haver a queda de produção, há o prejuízo direto ao empregador, com a destruição de máquinas e de instrumentos de trabalho. Esta, diferentemente daquela, consiste em ato ostensivo e público. No dia em que ela fosse proibida, a sabotagem, como sucedâneo lógico, teria que surgir. Por isso há uma conveniência política no reconhecimento do direito de greve ${ }^{438}$.

O label, por sua vez, significa a etiqueta ou rótulo que se afixa sobre os produtos fabricados, constituindo uma marca de garantia para transmitir aos consumidores que o artigo que está sendo adquirido foi feito por trabalhadores que mantém boas relações com o empregador. A finalidade principal é a recomendação do produto elaborado por pessoal sindicalizado ou pertencente a uma entidade que reconhece o sindicato. Para o uso de tal marca mostra-se imprescindível a autorização do empresário. O label não seria propriamente um meio de luta, mas uma colaboração, revelando harmonia nas relações de

\footnotetext{
435 A origem da palavra está relacionada com a atuação do Capitão Charles Cunningham Boycott, administrador de terras em um condado na Irlanda, contra quem os trabalhadores resolveram insurgir-se, por causa da forma dura e hostil de tratar os colonos. Consta que em 1879 os trabalhadores decidiram que nenhum irlandês poderia manter qualquer tratativa, nem prestar serviços, nem celebrar nenhuma transação de ordem comercial com o referido administrador, daí a origem da expressão "boicote" (BELTRAN, Ari Possidônio. A autotutela nas relações de trabalho. São Paulo: LTr, 1996, p. 172).

${ }^{436}$ GARCIA, Paulo. Direito de greve. Rio de Janeiro: Edições trabalhistas s.a, 1961, p. 107

${ }^{437}$ BELTRAN, Ari Possidônio. Op cit, p. 178.

${ }^{438}$ GARCIA, Paulo. Op cit, p. 81.
} 
trabalho, sendo assim marca de fábrica, reconhecido o sistema pela maioria das legislações entre os direitos conferidos aos sindicatos ${ }^{439}$.

A lista negra constituir-se-ia em procedimento tanto usado como meio de pressão sindical, como patronal. Trata-se de procedimento de ação direta do sindicato, mais usado contra empregados não sindicalizados no sentido de forçá-los à sindicalização ${ }^{440}$.

Outra forma de pressão dos trabalhadores consistiria na negativa de prestar horas extras, situação que merecerá enfoque diferenciado consoante cada ordenamento jurídico. Alguns consideram que se trata de uma prestação obrigatória que o empregado não pode recusar outros, ao contrário, têm a anuência relacionada apenas com as atitudes de colaboração extracontratuais ${ }^{441}$.

As situações anteriormente descritas, embora não integrem o conceito mais amplo de greve, também não são de criação recente. São formas de pressão dos empregadores pelos empregados utilizadas há muitos anos e, portanto, já bastante conhecidas e difundidas.

Como bem observa Márcio Túlio Viana “do mesmo modo que os homens buscam formas diferentes de fazer a guerra - como a guerrilha e o terror - os operários procuram, cada vez mais, modos alternativos de praticar a greve" ${ }^{442}$. Por essa razão observa Ermida Uriarte que "as opções de luta adotadas coletivamente pelos trabalhadores são extremamente variadas e estão em constante mudança, razão pela qual toda enumeração que se procure fazer será inevitavelmente incompleta" ${ }^{443}$.

Não fosse isto o bastante, as modificações de cunho tecnológico, político e sócioeconômico as quais já se fez referência têm provocado mudanças na ação dos sindicatos durante os movimentos paredistas. Percebendo que a simples paralisação das atividades laborais dos integrantes da categoria não resulta na paralisação das atividades de determinadas empresas, determinados sindicatos tem buscado, durante o curso do movimento grevista, outras formas de provocá-la. Tem sido cada vez mais frequentes a

\footnotetext{
${ }^{439}$ BELTRAN, Ari Possidônio. A autotutela nas relações de trabalho. São Paulo: LTr, 1996, p. 180/181.

${ }^{440}$ Ibidem, p. 183.

${ }^{441}$ Ibidem, p. 191.

442 VIANA, Márcio Túlio. Direito de resistência. São Paulo: LTr, 1996, p. 290.

443 ORGANIZAÇÃO INTERNACIONAL DO TRABALHO. A greve: o direito e a flexibilidade. Brasília: Organização Internacional do Trabalho, 2002, p. 88.
} 
realização de piquetes objetivando não apenas provocar a adesão de empregados ao movimento grevista, como também impedir o acesso de clientes (consumidores) e de não grevistas ao estabelecimento com intuito de paralisar toda a sua atividade. Novas estratégias vêm sendo utilizadas com o mesmo fim como, por exemplo, o besuntamento da entrada dos locais de trabalho, para impedir o acesso de clientes e não grevistas, a contratação de piquetistas "terceirizados" para evitar represálias posteriores aos trabalhadores que aderirem à greve de forma mais exaltada, entre outros.

A doutrina refere-se a outros exemplos de formas criativas de exercício do direito de greve. Márcio Túlio Viana refere-se a uma paralisação feita em uma conhecida usina siderúrgica do estado de São Paulo, considerada nos anos 70 "zona de segurança nacional" e, portanto, sujeita a rígido controle externo, com identificação de todos os trabalhadores através de crachá no momento de sua entrada. Como greve na aludida empresa, no auge da ditadura militar, era sempre considerada ilegal, os trabalhadores combinaram chegar à empresa sem crachá usando as portas do banheiro para intercambiar informações como jornais. Acordaram dizer na entrada que haviam esquecido o crachá o que provocou demora no ingresso na empresa, em decorrência do tempo dispendido para identificação, e ameça de apagamento dos altos fornos. Após este movimento que recebeu o nome de "Dia da Amnésia" a empresa negociou com os trabalhadores atendendo suas reivindicações ${ }^{444}$.

O mesmo autor menciona ainda, como forma de manifestação coletiva, o protesto dos carteiros de Curitiba contra os baixos salários raspando a cabeça de forma coletiva, em dezembro de $1995^{445}$.

Jorge Luiz Souto Maior observa que "podem ser estabelecidas implicações jurídicas aos efeitos da greve quando exercida com agressão a outros direitos, mas é impossível fixar o modo e a oportunidade de sua execução" ${ }^{446}$. Esta conclusão mostra-se perfeitamente adequada ao que estabelece o artigo $9^{\circ}$ da Constituição da República, cuja literalidade nos conduz a condenar as decisões proferidas tanto pela Justiça Federal quanto pela Justiça do Trabalho que limitaram o movimento paredista que os aeronautas haviam

\footnotetext{
${ }^{444}$ VIANA, Márcio Túlio. Direito de resistência: possibilidades de autodefesa do trabalhador em face do empregador. São Paulo: LTr, 1996, p. 317.

${ }^{445}$ Ibidem, p. 316/317.

${ }^{446}$ MAIOR, Jorge Luiz Souto. O direito de exercer o direito de greve. In: THOMÉ, Candy Florêncio e SCHWARZ, Rodrigo Garcia. Direito coletivo do trabalho: curso de revisão e atualização. Rio de Janeiro: Elsevier, 2010, p. 255.
} 
organizado no final de 2010, por considerá-lo inoportuno e excessivamente lesivo aos consumidores. É forçoso reconhecer que para uma análise mais adequada acerca do segundo argumento seria necessário analisar a colisão entre o direito dos trabalhadores e o dos consumidores, o que será feito em capítulo futuro. Igualmente imperioso é, no entanto, reconhecer que o judiciário não pode considerar abusiva uma greve em razão do momento escolhido para que ela fosse deflagrada, a menos que haja algum outro elemento fático como, por exemplo, o retardamento proposital das negociações para que o impasse permaneça até aquela data.

Chamam-se intermitentes, ou grèves tournantes, as que afetam alternativamente uma categoria depois outra, ou um estabelecimento em seguida de outro ${ }^{447}$. Elas reduzem, para os empregados, a incidência pecuniária do conflito porque eles não param suas atividades durante todo o tempo, mas a da empresa acaba paralisada durante toda a greve já que sempre haverá algum setor sem funcionar. Na França elas foram proibidas, em relação ao serviço público, pela lei n. 63-777, de 31 de julho de 1963. Nas atividades econômicas fora do âmbito de aplicação da referida lei elas são, via de regra, consideradas regulares ${ }^{448}$. Não foram, entretanto, reconhecidas como válidas quando houve uma desorganização grave do aparelho de produção. Entendeu a jurisprudência francesa que o perigo enfrentado pela empresa justificaria a imposição de sanções pelos excessos cometidos ${ }^{449}$.

A grève-bouchon caracteriza-se por uma paralisação do trabalho dos empregados de um atelier ou de um serviço, ou apenas em uma categoria profissional determinada, que paralisa o funcionamento da empresa ou de uma parte considerável dela. Difere da grève tournante por permanecer localizada em um ponto determinado da empresa, de importância essencial para o seu funcionamento, e que comanda a totalidade da produção. A jurisprudência francesa vem reconhecendo a validade da grève-bouchon ${ }^{450}$ quando a paralisação não traduzir uma completa desorganização da empresa, impondo-lhe um prejuízo excessivo. Há um precedente antigo considerando exercício abusivo do direito de

447 Segundo Bernard Teyssié, "les greves tournantes résultent d'arrêts de travail par catégories professionnelles ou par secteur affectant successivement les divers personnels de l'entreprise". TEYSSIÉ, Bernard. Grève dans le secteur privé. Jurisclasseur Travail Traité, fasc. 70-10, 15 avril 2010.

${ }^{448}$ Neste sentido é o precedente Cass. soc., 14 janv. 1960: JCP G 1960, II, 11704, 1 re esp., note F.D.; Dr. soc. 1960, p. 491 - Cass. soc., 2 mars 1960: Dr. Soc. 1960, p. 421, obs. H.F, apud TEYSSIE, Bernard. Grève dans le secteur privé. Jurisclasseur Travail Traité, fasc. 70-10, 15 avril 2010.

${ }^{449}$ Cass.soc., 22 avr. 1964: JCP G 1964, II, 13883. - Cass. soc., 16 juill. 1964: D. 1964, jurispr.. p. 705, note G. Lyon-Caen; JCP G 1964, II, 13943 bis, note B.A,; Dr. soc. 1965, p. 106, obs. J. Savatier. - Cass. soc., 31 mai 1967: Dr. soc. 1967, p. 631 cf TEYSSIÉ, Bernard. Grève dans le secteur privé. Jurisclasseur Travail Traité, fasc. 70-10, 15 avril 2010.

${ }^{450}$ Neste sentido é o precedente: Cass. soc., 5 juin 1973: Bull. Civ. 1973, V, n. 360, ibidem. 
greve as paralisações limitadas e repetidas do trabalho dentro de um único setor da cadeia de produção que revela que o verdadeiro objetivo dos grevistas é paralisar toda a cadeia de produção $^{451}$.

Após mencionar julgado que considerou que o fato de uma grève-bouchon se revelar mais onerosa para a empresa do que os movimentos clássicos não justificaria, por si só, o reconhecimento de sua irregularidade ${ }^{452}$, Bernard Teyssié pondera que mesmo que se trate de um elemento importante, o perigo enfrentado pela empresa deve ser analisado no conjunto com os demais elementos do conceito. Esta preocupação é importante na medida em que os empregados que intervêem em um ponto estratégico da empresa vão provocar uma perturbação séria na empresa, em um grau mais elevado do que a greve ordinária. Concluir automaticamquente pela irregularidade deste comportamento os privaria de fazer greve sem o apoio dos trabalhadores dos demais setores da empresa ${ }^{453}$.

Utiliza-se a expressão francesa grève sur le tas, ou simplesmente greve de braços cruzados, para designar a manifestação em que os trabalhadores permanecem no local de trabalho, mas se recusam a cumprir suas tarefas. A primeira expressão decorre justamente do fato de que a manifestação não deve ser confundida com uma simples reunião ou com a utilização de um tempo de pausa, mesmo remunerada, para apresentação de reinvindicações. Na França tem-se entendido que ela pressupõe uma deliberação coletiva prévia.

Há modalidades de greve que, embora sejam reconhecidas como válidas pela OIT $^{454}$ e praticadas em boa parte dos países do mundo, são incompatíveis com o regime de unicidade sindical adotado no Brasil até os nossos dias. É o caso das greves que tenham por objetivo o reconhecimento legal de sindicato para defender os interesses dos trabalhadores. Como o reconhecimento da legitimidade do sindicato no Brasil, que já foi

\footnotetext{
${ }^{451}$ Neste sentido é o precedente CA Paris, 5 nov. 1963: Gaz. Pal. 1964, 1, 270 apud TEYSSIÉ, Bernard. Grève dans le secteur privé. Jurisclasseur Travail Traité, fasc. 70-10, 15 avril 2010.

${ }^{452}$ Cass. soc., 10 janv. 1973: D. 1973, jurispr. p. 453, note H. Sinay. Ibidem

${ }^{453}$ TEYSSIÉ, Bernard. Grève dans le secteur privé. Jurisclasseur Travail Traité, fasc. 70-10, 15 avril 2010.

${ }^{454}$ Precedente 535 da $5^{\mathrm{a}}$ edição da Recopilación de decisiones y princípios del Comité de Libertad Sindical del Consejo de Administración de la OIT que assim dispõe: "El hecho de que se convoque una huelga por el reconocimiento legal de un sindicato constituye un caso de interés legítimo que deben defender los trabajadores y sus organizaciones". (Véase Recopilación de 1996, párrafo 487 y 302. ${ }^{\circ}$ informe, caso núm. 1809, párrafo 381.) Precedente 536 da Recopilación de decisiones y princípios del Comité de Libertad Sindical del Consejo de Administración de la OIT que assim dispõe: “ La prohibición de realizar huelgas por motivo de problemas de reconocimiento (para negociar colectivamente) no están en conformidad con los princípios de la libertad sindical". (Véase Recopilación de 1996, párrafo 488 y 321er informe, caso núm. 2066, párrafo 336).
} 
encargo do Ministério do Trabalho e Emprego, hoje é encargo do Judiciário, uma greve deste gênero poderia ser considerada política.

\subsection{LICITUDE DAS GREVES ATÍPICAS E DOS OUTROS MEIOS DE LUTA COLETIVA}

Segundo Márcio Túlio Viana, a doutrina, salvo as poucas exceções já analisadas, tende a concluir genericamente pela ilicitude das greves chamadas atípicas e dos outros meios de luta coletiva por considerar que haveria quebra do princípio de boa-fé, que deve presidir as relações entre capital e trabalho, mesmo durante o conflito e por falta de previsão legal $^{455}$.

O próprio Comitê de Liberdade Sindical da OIT tem se posicionado com bastante reserva acerca da admissibilidade destas modalidades de greve, considerando que elas só se justificariam quando a greve deixasse de ser pacífica ${ }^{456}$.

Mário Rusciano identifica, ao falar sobre o ordenamento jurídico italiano, tendência de aumento no número de greves gerais e políticas e nas formas anormais de luta sindical, inclusive das chamadas greves selvagem, que, segundo sua opinião, servem para abolir a raiva coletiva que se tem dos burgueses, mas não servem para resolver os problemas que dai derivam ${ }^{457}$. Em suas palavras:

Se l'insieme delle relazioni di lavoro e sindacali muta, in rapporto al mutare delle situazione economiche e sociali, si deve ritenere che anche il conflito assumerà, parallelamente, sfaccettature diverse, tali da modificarne la fisionomia, talora in profondità. E così, ad esempio, ci potrà essere una riduzione di incisività (specie quantitativa) dell'azione collettiva in determinati settori del lavoro oppure uno snaturamento dello sciopero nella sua forma clássica e la estrinsecazione della conflitualità attraverso manifestazioni

\footnotetext{
${ }^{455}$ VIANA, Márcio Túlio. Direito de resistência: possibilidadede de autodefesa do empregado em face do empregador. São Paulo: LTr, 1996, p. 318.

${ }^{456}$ Precedente 545 da $5^{\text {a }}$ edição da Recopilación de decisiones y princípios del Comité de Libertad Sindical del Consejo de Administración de la OIT que assim dispõe: "En cuanto a las modalidades del derecho de huelga denegado a los trabajadores (paralización intempestiva, trabajo a reglamento, huelga de brazos caídos, huelgas de celo, trabajo a ritmo lento, ocupación de la empresa o del centro de trabajo), el Comité consideró que tales limitaciones sólo se justificarían en los casos en que la huelga dejase de ser pacífica. (Véanse Recopilación de 1996, párrafos 496 y 497 y 306. informe, caso núm. 1865, párrafo 337.)

${ }^{457}$ RUSCIANO, Mario. Diritto di sciopero e assetto costituzionale. Rivista italiana di diritto del lavoro, 2009, I. G, p. 52.
} 
anomale di protesta collettiva (blocchi stradali o ferroviari, occupazione di luoghi di lavoro ecc..).

Né si può trascurare che, sul conflitto collettivo, pesa molto l'incidenza della grande trasformazione economico-sociale degli ultimi venti anni, provocata dalla c.d. rivoluzione tecnologica. Abbiamo infatti assitito - ora entusiasti, ora sgomenti - al progressivo declino dell'organizzazione taylor-fordista delle imprese e del lavoro all'affermarsi, in sostituzione, di <<um capitalismo delle reti >> segnato da innovazioni, che è poco definire inimmaginabili fino ad alcuni anni addietro ${ }^{458}$

Se analisadas sob a ótica clássica do direito de greve, referidas ações extrapolam o direito de greve na medida em que coagem trabalhadores a aderir involuntariamente à greve e impedem o direito de ir e vir dos clientes. Analisadas, contudo, sob a ótica do momento atual, há que se questionar se esta não reside na única forma de as entidades sindicais conseguirem pressionar os empregadores em busca de melhorias para a categoria profissional que representam. Como salienta Mario Rusciano,

quando la situazione conflittuale è incandescente, per um verso, è più difficile attendersi il rispetto dele regole da parte di chi protesta; $\mathrm{e}$, per um altro verso, è pìu difficile attendersi il rispetto dele regole da parte di chi protesta; e, per um altro verso, è più difficile applicare le sanzioni a chi non rispetta le regole: specie se poi va diradandosi la rappresentatività, l'autorevolezza e l'autonomia degli interlocutori, cioè di quegli enti esponenziali degli interessi organizzati, che oggi è di moda additare com $\mathrm{i}$ veri portatori di tutti i mali social $^{459}$.

Oscar Ermida Uriarte entende estar havendo, como forma de contraposição à flexibilização da organização do trabalho, uma flexibilização prática da greve, mediante o surgimento ou desenvolvimento de novas e atípicas modalidades de conflito coletivo, como forma de adaptação dos movimentos paredistas aos novos tempos. Em sua opinião, em sendo preciso flexibilizar a legislação trabalhista dos países latino-americanos, deverse-ia começar, e em maior extensão, pela legislação sobre sindicalização, negociação coletiva e greve, o que não vem acontecendo. Todas as reformas legislativas flexibilizadoras têm-se concentrado na desregulamentação do direito individual do trabalho, mantendo, em termos gerais, o caráter interventor, regulamentarista e restritivo da

\footnotetext{
${ }^{458}$ RUSCIANO, Mario. Diritto di sciopero e assetto costituzionale. Rivista italiana di diritto del lavoro, 2009, I. G, p. 52, p. 54.

${ }^{459}$ Idem.
} 
legislação sobre o direito coletivo do trabalho ${ }^{460}$, o que justifica o fato de a flexibilização da greve estar nascendo a partir da reação da sociedade e não de iniciativas do legislador.

Um bom exemplo de flexibilidade no exercício do direito de greve na iniciativa privada é dado pela França, país em que não se aplica às greves desencadeadas no setor privado as disposições da lei de 31 de julho de 1963, que impõe a observância de preaviso antes da deflagração de uma greve nos serviços públicos. Essa falta de regulamentação legal do direito faz com que a definição acerca da abusividade ou não de determinado movimento paredista seja ditada pelo Poder Judiciário, em análise direta dos casos concretos submetidos à sua apreciação.

Em razão dessa falta de regulamentação legal os empregados da iniciativa privada são livres para escolher o momento em que cessarão suas atividades, sem ter que respeitar qualquer formalidade prévia. Segundo já decidiu a Corte de Cassação, será suficiente que o empregador conheça as reivindicações formuladas no momento da paralisação do trabalho $^{461}$. Em outra decisão afirmou que eles estariam no direito de interromper sua atividade imediatamente após apresentar as reivindicações, sem precisar sequer esperar a sua eventual rejeição ${ }^{462}$.

$\mathrm{Na}$ decisão mais relevante para a solução do caso que importa analisar, a Corte de Cassação francesa asseverou que tendo o direito de escolher um momento particularmente favorável à eficácia da greve deflagrada, os grevistas não poderiam ser repreendidos por haver escolhido determinada data ao simples motivo de que ela poderia impor ao empregador um dano elevado ${ }^{463}$. Sob esta perspectiva a greve dos aeronautas a qual se fez referência não poderia haver sido considerada irregular por terem eles considerado oportuno o ajuizamento do movimento pouco antes das festividades de fim de ano.

Durante algum tempo a Corte de cassação entendeu válidas as disposições convencionais que impusessem o respeito a um aviso prévio ${ }^{464}$. Este entendimento, contudo, foi abandonado nos anos 90 quando a aludida Corte passou a entender que "une

\footnotetext{
${ }^{460}$ ORGANIZAÇÃO INTERNACIONAL DO TRABALHO. A greve: o direito e a flexibilidade. Brasília: Organização Internacional do Trabalho, 2002, p. 87.

${ }^{461}$ Cass. soc., 19 nov. 1996: TPS 1997, comm. 17 apud TEYSSIÉ, Bernard. Grève dans le secteur privé. Jurisclasseur Travail Traité, fasc. 70-10, 15 avril 2010.

${ }^{462}$ Cass. soc., 20 de maio de 1992: Cah. Soc. 1992, A 41. Ibidem.

${ }^{463}$ Cass. soc., 13 mars 1980: D. 1980, inf. Rap. P. 546, obs. J. Pélissier. Ibidem

${ }^{464}$ Cass. soc., 27 févr. 1974: Bull. Civ. 1974, V, n. 140. Ibidem.
} 
convention collective ne peut avoir pour effet de limiter ou de réglementer pour les salariés l'exercice du droit de grève constitutionnellement reconnu; seule la loi peut créer un délai de préavis de grève "imposant à eux",465.

A Corte de Cassação modificou novamente o seu entendimento a partir da decisão n. 2007-556 DC do Conselho Constitucional, proferida em 16 de agosto de $2007^{466}$. O Coselho entendeu na ocasião que como o legislador haveria confiado à negociação coletiva "le soin de préciser les modalités d'application des règles fixées par lui pour l'exercice du droit de grève", o Parlamento poderia reenviar aos atores sociais a tarefa de precisar seus contornos, sua substância e sua duração. Um acordo coletivo poderia, outrossim, regulamentar o exercício de direito de greve, fazendo-o, contudo, em nome da lei ${ }^{467}$.

Segundo Bernard Teyssié, a fim de reduzir os incidentes pecuniários da greve, a jurisprudência francesa considera que os trabalhadores podem, eventualmente, recorrer a movimentos de breve duração, de uma hora, por exemplo. Realizada em momentos pontuais, essas paralisações de trabalho são, em muitos casos, repetidas diversas vezes ao curso de uma mesma jornada ou de uma semana ${ }^{468}$.

A Corte de Cassação Francesa reconheceu a validade das greves de curta duração realizadas no início ou no fim da jornada, quando os trabalhadores chegam propositalmente com algums minutos de atraso ou deixam a empresa antes da hora

${ }^{465}$ Cass. soc., 7 juin 1995: RJS 1995, n. 933; Dr. soc. 1996, p. 37, obs. C. Radé; D. 1996, jurispr. p. 75, note B. Mathieu - Adde Cass. soc., 12 mars 1996: RJTS 1996, n. 439 - Cass. soc., 17 juill. 1996: RJS 1996, n. 1079 apud TEYSSIÉ, Bernard. Grève dans le secteur privé. Jurisclasseur Travail Traité, fasc. 70-10, 15 avril 2010.

466 Journal Officiel 22 Aout 2007, apud TEYSSIÉ, Bernard. Grève dans le secteur privé. Jurisclasseur Travail Traité, fasc. 70-10, 15 avril 2010.

467 TEYSSIÉ, Bernard. Grève dans le secteur privé. Jurisclasseur Travail Traité, fasc. 70-10, 15 avril 2010.

${ }^{468}$ Segundo Teyssié, em conclusões obtidas a partir de minucioso estudo na jurisprudência francesa: "Le fait que des greves de courte durée soient plusieurs fois répétées à quelques heures ou jours d'intervalle, n'est pas, a priori, de nature à em affecter la régularité (Cass.soc., 11 mars 1964: Bull. Civ. 1964, IV, n. 234. Cass. soc., 16 juill. 1964: Dr. soc. 1965, p. 106, obs. J. Savatier. - Cass. soc., 25 févr. 1988: D. 1988, somm. P. 326, 2e esp., obs. Ph. Langlois. - Cass. soc., 30 mai 1989: Action juridique 1989, n. 79, p. 23. - Cass. soc., 7 avr. 1993: RJS 1993, n. 539I). il en va toutefois différemment lorsque la sucession des débrayages se traduit par la désorganisation de l'entreprise (Cass. soc., 7 janv. 1960: Bull. Civ. 1960, IV, n. 20. - Cassl. Soc., 13 déc. 1962: Dr. soc. 1963, p. 226, obs. J. Savatier - Cass. soc., 7 janv. 1988: Dr. soc. 1988, p. 156, obs. A. Mazeaud et p. 259, obs. J. Savaier, relevant que "les arrêts de travail n'étaient généralement pas affichés au sein de l'entreprise ni portés par quelque moyen que ce soit à la connaissance de l'employer, qu'ils avaient perturbé gravemente l'organisation de la société.. et que le préjudice qui em était résulté excédait celui qui resulte normalement de l'exercice d'une grève continue ou même de débrayages controles”). (TEYSSIÉ, Bernard. Grève dans le secteur privé. Jurisclasseur Travail Traité, fasc. 70-10, 15 avril 2010) 
prevista $^{469}$. A doutrina francesa também reputa greve de curta duração e reconhece validade às paralisações feitas no curso da jornada de trabalho em que, durante alguns minutos, os trabalhadores permanecem na empresa aguardando o momento de recomeçar as atividades consoante determinação do comando de greve. Estas paralisações no trabalho, frequentemente consideradas pelos trabalhadores simples "greves d'advertissement", mereceriam a qualificação de greve por apresentarem caráter coletivo e finalidade profissional, pouco importanto, para fins de caracterização do movimento, a sua duração. A sua brevidade não afetaria sua regularidade. O exercício do direito de greve não está, segundo as disposições legais em vigor na França, vinculado ao respeito de um mínimo de paralisação ${ }^{470}$.

Bernard Teyssié observa, entretanto, que quando as paralisações de trabalho tornam-se, em razão de seu número, gravemente prejudiciais à empresa, a Corte de Cassação não hesita em proceder à desqualificação do movimento, recusando-se a considerá-lo uma greve autêntica. Estar-se-ia nessa hipótese, segundo os precedentes $\operatorname{citados}^{471}$, diante de uma execução irregular do trabalho e não do exercício do direito de greve. O fundamento das conclusões seria o de que os empregados não estão autorizados a, sob alegação de greve de curta duração, executar seu trabalho dentro de condições diversas daquelas previstas no contrato de trabalho ou praticadas ordinariamente em sua profissão.

Não obstante exista uma lei demasiadamente restritiva quanto ao exercício do direito de greve, no ordenamento jurídico brasileiro também compete ao judiciário decidir com exclusividade acerca da abusividade da greve, o que torna primordial o papel dos magistrados na análise desta questão. Há que se ponderar, no entanto, se ele estaria adstrito ao conceito legal de greve, que no caso brasileiro mostra-se, pelas razões já expostas, demasiadamente restritivo e muito ultrapassado, ou se ele poderia exercer uma função mais criativa do direito, pugnando pela adaptação do conceito e das exigências legais à nova realidade sócio-econômica.

A resposta inclina-se para a segundo possibilidade já que, como bem acentuou Roger Latournerie há quarenta anos, em obra em que dedica sessenta páginas ao estudo do

\footnotetext{
${ }^{469}$ Cass. soc., 6 nov. 1958: Dr. soc. 1959, p. 291, cf TEYSSIÉ, Bernard. Grève dans le secteur privé. Jurisclasseur Travail Traité, fasc. 70-10, 15 avril 2010

${ }^{470}$ TEYSSIÉ, Bernard. Grève dans le secteur privé. Jurisclasseur Travail Traité, fasc. 70-10, 15 avril 2010.

${ }^{471}$ O autor francês menciona os seguintes julgados: Cass. soc. 18 févr. 1960: JCP G 1960, II, 11704, 2e esp., note F.D.; Dr. soc. 1960, p. 490, obs. H.F. - Cass. soc., 3 mars 1983: JCP CI 1983, I, 11731, p. 264, n. 8, obs. B. Teyssié.
} 
papel do juiz francês em face do direito de greve, “il n'y aurait pas d'entreprise plus vaine et, à certains égards, plus dangereuse que de prétendre réduire le domaine du droit à celui des textes législatifs". Em sua opinião a função do juiz pode ser, dentro de casos extremos, até mesmo suprir o silêncio dos textos. Mais até "Son devoir est, en effet, quand ceux-ci sont muets, de donner une forme et une voix, ainsi qu'une force exécutoire à cette communauté de sentiments, sinon d'idées qu'à défaut d'un terme plus précis, on nome la consciente collective" ${ }^{, 42}$.

Homero Mateus Batista da Silva propõe, de forma bastante acertada, um alargamento do conceito de greve baseado em dois motivos. Primeiramente porque a greve, como um fato, dificilmente poderia ser delineada pelo legislador de forma restritiva, o que, conquanto torne razoável que se coibam alguns atos de abuso e de excesso, raramente possibilitará uma definição que não seja reducionista. Em segundo lugar porque a exata dimensão e dificuldade de se conceituar greve teria sido dada pelo artigo $9^{\circ}$ da Constituição Federal de 1988 que delegou aos próprios trabalhadores o ônus de decidir sobre a oportunidade de exercê-lo e sobre os interesses que devam por meio dele defender ${ }^{473}$.

Admitindo a premissa de que a pressão dos fatos sobre o direito se exerce, com alguma frequência, com força extrema, lhe confere um poder constrangedor tal que força $o$ próprio legislador a ceder e reformular a legislação, razão assiste à Roger Latournerie ao afirmar que "il n'est pas un juriste qui en disconvienne et, lorsque l'écart, le hiatus entre le droit et le fait devient patente et même dangereux, l'accord se manifeste entre les auteurs sur l'utilité et même sur la necessite d'y mettre fin, ou du moins de le réduire autant qu'il est possible" ${ }^{474}$.

Diante das alterações provocadas no mundo do trabalho, sobre as quais já se discorreu neste estudo, há que se concordar com Bernard Teyssié, segundo quem nenhuma modalidade particular de interrupção do contrato de trabalho deverá ser considerada irregular, na ausência de norma legal a proibindo ${ }^{475}$. O problema, contudo, analisando a questão sob a perspectiva do ordenamento jurídico brasileiro, é encontrar a forma de

${ }^{472}$ LATOURNERIE, Roger. Le droit français de la grève: etude théorique et pratique. Paris: Sirey: 1972, p. $16 / 17$.

${ }^{473}$ SILVA, Homero Mateus Batista da. Curso de direito do trabalho aplicado, vol. 7: direito coletivo do trabalho. Rio de Janeiro: Elsevier, 2010, p. 258.

${ }^{474}$ LAUTORNERIE, Roger. Op cit, p. 28

${ }^{475}$ TEYSSIÉ, Bernard. Grève dans le secteur privé. Jurisclasseur Travail Traité, fasc. 70-10, 15 avril 2010. 
harmonizar estas manifestações com os requisitos formais impostos pela Lei 7.783, como a exigência frustração das tentativas de negociação, de deliberação por assembléia coletiva e de pré-aviso.

Só é possível harmonizar essas exigências por meio de uma interpretação da legislação feita a partir do artigo $9^{\circ}$ da Constituição. Além de permitir uma ampliação no rol de legitimados para os movimentos grevistas, referido dispositivo legal, segundo a leitura aqui proposta, somente admite a intervenção judicial nos movimentos grevistas para atender as necessidades inadiáveis da comunidade, conforme atividades essenciais definidas em lei, e a punição por abusos cometidos no exercício do direito de greve.

Os abusos em questão somente poderão ser identificados após a deflagração do movimento. Não há como pressupor ou presumir que o movimento será abusivo. E como o texto constitucional fala que as sanções serão definidas em lei, mas em momento algum fala que o conceito de abusividade será definido em norma infraconstitucional, reconhecese ao magistrado a possibilidade de considerar que determinado movimento paredista, apesar de deflagrado sem a observância de todas as formalidades impostas pela lei, não é abusivo, deixando, por essa razão, de aplicar as sanções cabíveis. Seria a situação verificável, por exemplo, na hipótese de a falta de aviso prévio não ter gerado nenhum prejuízo ao empregador que, embora não tenha sido comunicado formalmente, suspeita da iminência da paralisação das atividades pelo comportamento adotado por seus próprios empregados e adota as precauções ao seu alcance.

O magistrado pode também, a partir desta leitura, não considerar abusivo e, portanto, deixar de aplicar sanção, a uma greve ambiental deflagrada pelos trabalhadores sem aviso prévio por considerar que estes agiram em estado de necessidade e em situação de inexigibilidade de conduta adversa.

A leitura ora sugerida para a Lei 7783/89, feita a partir do artigo $9^{\circ}$ da Constituição Federal, consagra a tese sustentada por Márcio Túlio Viana, segundo quem "a licitude de quaisquer formas de resistência coletiva dependerá de não provocarem prejuízos de natureza substancialmente diversa e mais grave que os causados por uma eventual greve típica, junto ao mesmo empregador" ${ }^{476}$.

\footnotetext{
${ }^{476}$ VIANA, Márcio Túlio. Direito de resistência: possibilidades de autodefesa do empregado em face do empregador. São Paulo: LTr, 1996, p. 318.
} 
Com isso, eventual conclusão acerca da abusividade de um movimento não poderá ter como fundamento apenas a atipicidade da forma de manifestação. Em outras palavras, o simples fato de ela não se enquadrar dentro do conceito legal de greve, seja em razão de não ser dirigida diretamente em face do empregador formal, mas em face da empresa cliente, que dele toma serviços, seja em razão de não consistir na efetiva suspensão da prestação de serviços por trabalhador, por si só, não torna a greve ilícita. Para merecer essa capitulação é imprescindível que a ação coletiva tenha, de forma dolosa e intencional, causado um dano à produtividade do trabalhador e não à sua produção, como ocorre, por exemplo, com movimentos que deliberadamente danifiquem o maquinário da empresa.

Como essa análise deverá ser sempre feita a posteriori, a não observância de determinados procedimentos formais não deverá conduzir à uma conclusão acerca da ilicitude ou ilegitimidade da greve quando não ficar comprovado o prejuízo causado à produtividade.

No tocante aos consumidores ou usuários de serviços, a greve deverá ser considerada abusiva apenas quando a ação coletiva lhes retirar toda e qualquer possibilidade de ter acesso ao serviço oferecido. Sempre que remanescer alguma possibilidade de obtenção do serviço, ainda que de forma menos prática e mais desgastante, o movimento deverá ser reconhecido como legítimo. Seguindo essa linha de raciocínio, uma paralisação nos serviços de transporte aéreo não deverá ser reputada abusiva enquanto houver a possibilidade de outros meios de transporte que, de uma forma mais demorada, permitam aos usuários chegar ao destino. Um movimento dos aeronautas e aeroviários que paralise, às vésperas das festas de fim de ano, todos os vôos de menor duração, mantendo aqueles mais longos, cujo trajeto por via terrestre ou marítima não seria acessível aos consumidores por outra via, não poderia ser reputada inválida.

O desconforto causado aos consumidores que precisarem viajar de carro próprio, ônibus ou navio em razão da suspensão do transporte aéreo nos trajetos mais curtos é natural dos regimes democráticos que reconhecem a greve como instrumento de conquistas sociais. 


\subsection{MEIOS COLETIVOS DE PRESSÃO DOS EMPREGADORES}

Oscar Ermida Uriarte observa que, por razões jurídicas e políticas, se presta menos atenção e se atribui menos importância aos meios patronais de conflito que aos utilizados pelos trabalhadores. Juridicamente porque na dogmática do direito coletivo do trabalho a autotutela faz parte da proteção dos trabalhadores, o que a legitima, pelo menos em princípio, como conjunto de ações unilaterais dos trabalhadores com escopo compensatório e equilibrador. As ações patronais não apresentam essa função, mais ainda, a contradizem ou limitam. Politicamente não se tem dado tanta atenção as ações patronais porque elas apresentam, em geral, efeito perturbador muito menor do que as ações sindicais 477 .

Em verdade, os empregadores, em geral, nem sequer precisam exercer pressão sobre os trabalhadores. A própria situação de escassez de emprego, a pressão do risco do desemprego (alguns chegar a chamar de chantagem do desemprego) operam como importante pressão do setor empregador sobre o sindical. O mesmo podendo ser dito em relação às novas formas de organização do trabalho que também atuam enfraquecendo a eficácia de algumas ações sindicais e fortalecendo a posição patronal ${ }^{478}$.

Não fosse isto o bastante, é forçoso ressaltar que a maior parte das ações patronais de conflito consistiria na utilização de seus poderes naturais, tais como poder de dispensa, de aplicar sanções disciplinares, de promover ou deixar de promover alguém, de contratar alguém ou deixar de contratar, como meio de pressão. Poucas, em verdade são as ações patronais geneticamente conflitivas, assim entendidas as que foram criadas ou concebidas como modalidade de conflito. Ermida Uriarte pondera que talvez apenas as listas negras e o locaute possuam efetivamente originalidade, autonomia e especialidade conflitiva, não sendo apenas o uso ou adaptação conflitiva de outros poderes reconhecidos para outros efeitos $^{479}$.

Cabe mencionar como modalidades de conflito coletivo por iniciativa patronal o lobby político, o boicote (tanto o tradicional como o que supõe desvios de investimentos, especulação, ágio) e a participação política, seja ela direta, quando empresários, assessores

477 ORGANIZAÇÃO INTERNACIONAL DO TRABALHO. A greve: o direito e a flexibilidade. Brasília: Organização Internacional do Trabalho, 2002, p. 91.

${ }_{478}$ Ibidem, 93/94.

${ }^{479}$ Ibidem, 2002, p. 91. 
ou dirigentes empresariais assumem diretamente cargos políticos, quanto indireta, por meio de financimento de candidatos ou partidos real ou aparentemente independentes ${ }^{480}$.

Cabe ainda ressaltar que não raro os empregadores utilizam como forma de contraofensiva a ação sindical, prerrogativas do seu poder diretivo, como advertências, intimações, suspensões etc., e até o chamado "desvio produtivo ou financeiro", isto é, a ameaça de não instalar uma planta ou de suspender ou não fazer um investimento produtivo $^{481}$. Não obstante estas prerrogativas sejam inerentes a todo contrato de trabalho, quando utilizadas para enfraquecer a ação coletiva dos trabalhadores elas adquirem a feição de conduta antissindical.

Criatividade e inovações podem ser vistas também na contraofensiva dos empregadores a estas novas formas de movimento paredista. Há relatos, por exemplo, de empresas que utilizam helicópteros para que seus empregados cheguem ao trabalho pela via aérea, burlando assim os bloqueios terrestres eventualmente organizados ${ }^{482}$. Esta prática, a princípio, nada tem de ilícito. Será, entretanto, irregular se o trabalhador transportado for constrangido a fazer o percurso dessa forma apesar de ter medo de altura ou de desejar fazer parte da paralisação.

Ermida Uriarte faz referência também a algumas práticas empresariais interessantes como a instituição de seguros patronais ou ajudas mútuas em face dos efeitos da greve, comuns na Suécia. Os empresários formam fundos de seguro administrados por uma confederação empresarial de cúpula, que paga subsídios às empresas que sofreram greves prejudiciais. A chamada assistência mútua seria uma forma de compensar determinada ou determinadas empresas que supostamente tenham sofrido prejuízo substancial em razão de uma greve, evitando que outras se beneficiem ou lucrem desproporcionalmente em decorrência dessa situação ${ }^{483}$.

Por fim, há que se destacar, com apoio novamente nas lições de Oscar Ermida Uriarte, que "as vias judiciais podem ser também utilizadas como pressão sobre algum dos

${ }^{480}$ ORGANIZAÇÃO INTERNACIONAL DO TRABALHO. A greve: o direito e a flexibilidade. Brasília: Organização Internacional do Trabalho, 2002, p. 92.

481 Ibidem, p. 92.

$482 \quad$ Disponível em

<http://oglobo.globo.com/economia/mat/2008/10/09/itau_usa_helicopteros_para_driblar_greve_dos_bancari os-548653736.asp>. Acesso em 01/01/2011

${ }^{483}$ ORGANIZAÇÃO INTERNACIONAL DO TRABALHO. Op cit, p. 92. 
atores do sistema de relação de trabalho" ${ }^{484}$. Ações de embargo, sentenças ou medidas cautelares (segundo os diferentes ordenamentos jurídicos e processos de responsabilidade patrimonial movidos em decorrência de ações coletivas de trabalhadores) ${ }^{485}$.

A perversidade gerada para os trabalhadores em decorrência dessa situação é imensurável. Se a fragilidade dos trabalhadores no cenário sócio-econômico e político atual é tão acentuada que os empregadores em geral nem sequer precisam exercer pressão coletiva sobre os trabalhadores, é difícil até mensurar o tamanho do inconveniente gerado pela intervenção do judiciário tutelando direitos dos empregadores em detrimento dos direitos dos trabalhadores. Se estes esperavam socorro do judiciário, sobretudo quando há uma Justiça especializada instituída apenas para julgar ações decorrentes das relações de trabalho e situações conexas, como é o caso brasileiro, não é preciso muito para descrever a situação de desamparo a que são relegados quando este órgão acaba dando guarida aos interesses patrimoniais dos empregadores ou dos usuários e consumidores de determinados serviços em detrimento dos seus.

Quando a contraofensiva dos empregadores consiste em violação a alguma das garantias ao exercício da greve, como a dispensa coletiva ou substituição imediata dos grevistas, os trabalhadores podem se socorrer do judiciário para tentar invalidá-la. O que lhes resta, entretanto, a fazer quando a contraofensiva consiste na obtenção de uma ordem judicial que enfraquece o movimento? A única possibilidade legal e legítima é recorrer para invalidar a decisão. O grande problema é que o conflito coletivo em geral termina antes do julgamento do recurso. Em verdade, termina muitas vezes antes mesmo que o mérito da ação em que foi concedido provimento liminar seja julgado.

\subsection{GARANTIAS AO EXECÍCIO DO DIREITO DE GREVE}

Octávio Bueno Magano e Estêvão Mallet, bem observam que ao lado das limitações ao direito de greve, o legislador consagrou as seguintes garantias para o seu exercício: a) a do emprego de meios pacíficos tendentes a persuadir ou aliciar trabalhadores; b) a de arrecadação de fundos; c) a de divulgação do movimento; d) a de proibição imposta a empresas de adotarem procedimentos ilícitos, visando à frustração da

\footnotetext{
${ }^{484}$ ORGANIZAÇÃO INTERNACIONAL DO TRABALHO. A greve: o direito e a flexibilidade. Brasília: Organização Internacional do Trabalho, 2002, p. 92.

485 Ibidem.
} 
greve; e) a vedação de despedimento de grevistas, no curso da paralisação; f) a de interdição da contratação de trabalhadores para substituir grevistas, salvo a hipótese de paralisação de que possa resultar prejuízo irreparável, pela deterioração irreversível de bens, máquinas e equipamentos ${ }^{486}$.

No tocante ao emprego de meios pacíficos tendentes a persuadir ou aliciar os trabalhadores, cabe ressaltar que não obstante essa garantia seja comumente associada com os piquetes, ela não se restringe a eles. Estratégia interessante é a utilização da imprensa como instrumento para tentar conquistar simpatia para o movimento grevista, sobretudo através da ocupação do espaço simbólico do adversário em sua publicidade e em sua imagem na mídia. Ermida Uriarte exemplifica mencionando a contratação de espaços para informativos na televisão sobre a situação do conflito ou no placar eletrônico do Estádio Centenário, em Montevidéu, numa partida internacional de futebol na qual jogava um time da mesma nacionalidade que a casa matriz da empresa em conflito ${ }^{487}$. A contratação da imprensa também pode ser um bom mecanismo de divulgação do movimento para consumidores e usuários dos serviços. Como salienta Lyon-Caen, a greve se exerce sob o controle da opinião pública, sendo, "un fait d'opinion". Em suas palavras, "Les titulaire du droit de grève savent que la grève qui se heurte à l'hostilité de l'opinion, s'autodétruit, et lèse les intérêts des grévistes eux-mêmes" ${ }^{488}$.

Outra forma interessante seria a distribuição de panfletos informando aos clientes da empresa acerca das más-condições de trabalho. Como já se teve oportunidade de defender, esta distribuição poderá ser feita dentro do próprio estabelecimento da empresa desde que de forma pacífica e sem causar tumultos. Quanto a esta última observação cabe fazer a ressalva de que muitas vezes a perturbação ao ambiente não é gerada pelos trabalhadores, mas pelos seguranças do empregador na tentativa de expulsar os manifestantes ou de impedir a distribuição do material de divulgação.

A autorização para arrecadação de fundos, que no Brasil está expressa no artigo $6^{\circ}$, II da Lei 7.783/89, objetiva assegurar aos trabalhadores meios para custear o movimento paredista. Embora a lei não seja detalhista quanto a este ponto, é forçoso reconhecer que o

\footnotetext{
${ }^{486}$ MAGANO, Octávio Bueno; MALLET, Estêvão. O direito do trabalho na constituição. Rio de Janeiro: Forense, 1993, p. 312.

${ }^{487}$ ORGANIZAÇÃO INTERNACIONAL DO TRABALHO. A greve: o direito e a flexibilidade. Brasília: Organização Internacional do Trabalho, 2002, p. 100.

${ }^{488}$ LYON-CAEN, Gerard. Réglementer le droit de grève? Droit social, n.9-10, septembre-octobre 1988, $p$. 712.
} 
valor arrecadado tanto poderá ser utilizado para confecção do material necessário para as manifestações, como cartazes e panfletos, quanto para manutenção da subsistência dos grevistas durante o período de suspensão do contrato. A norma também é silente quanto aos possíveis doadores, o que a princípio permitiria que qualquer interessado que tenha ciência do movimento destine recursos para a sua manutenção. É comum sindicatos divulgarem na rede mundial de computadores os dados bancários para que os depósitos possam ser feitos sem identificação ${ }^{489}$. O risco, nesses casos, é de patrocínio do movimento grevista por uma concorrente do empregador o que, em tese, não seria irregular sob o ponto de vista do direito sindical, mas certamente poderá ser considerado forma de concorrência desleal.

A adoção de procedimentos ilícitos visando à frustração da greve, consiste numa das mais graves formas de comportamento antissindical, gênero que engloba todas as condutas contrárias aos atos de liberdade sindical e que, por conseguinte, “obstaculizam o exercício pleno de uma liberdade indispensável à existência e à construção permanente de um regime democrático" ${ }^{„ 90}$. Luciano Martinez exemplica esse tipo de conduta com a perseguição aos dirigentes sindicais, as despedidas punitivas e a desmoralização das lideranças operárias, deixando claro que o rol de possíveis ações obstativas da liberdade sindical é muito maior ${ }^{491}$.

Após observar que tem sido crescente a casuística de movimentação de certos empregadores em direção à intervenção na organização sindical de trabalhadores, Antonio Rodrigues de Freitas Júnior, ressalta a premência de elaboração de refinamento dos mecanismos jurídicos disponíveis, no Brasil, à coibição de condutas antissindicais ${ }^{492}$. Verificando-se a normatização proposta pelo referido autor, seria de grande valia que se incluísse entre as condutas antissindicais a indevida utilização ou tentativa de utilização dos órgãos do Poder Judiciário para enfraquecimento da ação coletiva dos trabalhadores.

\footnotetext{
${ }^{489}$ Observe-se, a este respeito, o que diz a mensagem do Sindicato Estadual dos Profissionais da Educação do Rio de Janeiro, disponível no sítio < http://sepe4.blogspot.com/2011/07/campanha-de-arrecadacao-defundos-para.html>, acesso em 12 de janeiro de 2012.

490 MARTINEZ, Luciano. Curso de direito do trabalho: relações individuais, sindicais e coletivas do trabalho. São Paulo: Saraiva, 2010, p. 603.

${ }^{491}$ Ibidem, p. 604.

492 FREITAS JÚNIOR, Antonio Rodrigues de. Novas perspectivas para o Direito Coletivo do Trabalho no Brasil (ou sobre a premência da disciplina legal da conduta antissindical). Revista do Advogado, ano XXX, n. 110, Dezembro de 2010, p. 23.
} 
Uma das principais formas de conduta antissindical relacionada com a aututela de seus interesses é a perseguição ou tratamento diferenciado dos trabalhadores grevistas. Apesar de não existir disposições específicas nas suas convenções e recomendações contra os atos de discriminação por motivo de greve, a OIT considera que a toda proteção contra ato antidiscriminatório que menoscabe a liberdade sindical se encontra genericamente consagrada pelas Convenções número 98, 135 e 151, que tratam, respectivamente, do direito de sindicalização e negociação coletiva, dos representantes dos trabalhadores e das relações de trabalho na Administração Pública ${ }^{493}$.

Demais disso, a Comissão de Peritos da OIT já acentuou que a proteção que se brinda aos trabalhadores e aos dirigentes sindicais contra os atos de discriminação antissindical é um elemento essencial do direito sindical porque tais atos podem configurar a negação das garantias previstas na Convenção n. 87 da OIT $^{494}$. Asseverou também que no que se refere especificamente ao direito de greve, a conservação do vínculo de emprego deve ser tida como consequência normal do reconhecimento do direito de greve, razão pela qual o exercício legítimo desse direito não deve resultar em dispensa ou discriminação contra os grevistas ${ }^{495}$.

Entre os atos de discriminação antissindical fundados no exercício de greves legítimas o Comitê de Liberdade Sindical da Organização Internacional do Trabalho já reconheceu, analisando queixas que lhe foram apresentadas, a confecção de listas com o nome das pessoas que participaram das greves (em particular para que lhes seja negada contratação), a transferência de dirigentes sindicais, a exigência de certificados de lealdade para poder ser readmitido ou contratado, os rebaixamentos, as aposentadorias antecipadas obrigatórias, as sanções penais, entre outras ${ }^{496}$.

Para proteger os dirigentes sindicais, algumas legislações estipulam mecanismos de caráter preventivo, exigindo, por exemplo, que certas medidas contra os representantes dos trabalhadores ou dirigentes sindicais estejam sujeitas a uma autorização prévia por parte de um organismo independente ou público (inspeção do trabalho ou tribunais do trabalho), de um organismo sindical ou de um comitê de empresa. É o que se verifica no Brasil, país em

\footnotetext{
${ }^{493}$ ORGANIZAÇÃO INTERNACIONAL DO TRABALHO. Principios da la OIT sobre el derecho de huelga. Genebra: Organização Internacional do Trabalho, 2000, p. 36/37.

${ }^{494}$ Ibidem, p. 36.

${ }^{495}$ Ibidem, p. 38

${ }^{496}$ Ibidem, p. 40.
} 
que o ordenamento jurídico exige que o empregador ajuíze um inquérito judicial para apuração de falta grave, prove a irregularidade cometida pelo dirigente sindical, para somente por decisão judicial o vínculo empregatício ser desfeito. A maioria das outras legislações, contudo, teria optado por um sistema de reparação pelo prejuízo ocasionado ${ }^{497}$.

O Comitê de Peritos da OIT considera que a reintegração do trabalhador dispensado com o pagamento das indenizações retroativas constitui o meio mais apropriado de remediar os atos de discriminação antissindical. O Comitê de Liberdade Sindical também estipula que aqueles que sejam objeto de discriminação também deveriam ter a possibilidade de reintegração no posto de trabalho ${ }^{498}$.

No Brasil a proteção ao dirigente sindical encontra amparo na própria Carta Magna que, em seu artigo $8^{\circ}$, VIII, veda a dispensa do empregado sindicalizado a partir do registro da candidatura a cargo de direção ou representação sindical e, se eleito, ainda que suplente, até um ano após o final do mandato, salvo se cometer falta grave nos termos da lei.

Outra garantia ao exercício do direito de greve encontra-se no artigo $7^{\circ}$, parágrafo único da Lei 7.783/89 que veda a rescisão de contrato de trabalho durante a greve, bem como a contratação de trabalhadores substitutos, exceto se a greve for considerada abusiva ou se não forem mantidos em atividade equipes de empregados com o propósito de assegurar os serviços cuja paralisação resultem em prejuízo irreperával pela deterioração irreversível de bens, máquinas e equipamentos, bem como a manutenção daquelas essenciais à retomada das atividades da empresa quando da cessação do movimento. Propõe-se, também quanto a este preceito, uma interpretação evolutiva. Conquanto a lei tenha impedido a substituição de trabalhadores por outros, o alto nível de automação a que chegamos já permite que, durante determinado movimento grevista, setores inteiros de determinado estabelecimento seja automatizado em represália à adesão ao movimento grevista. Nesses casos, a forma de não permitir que o aludido dispositivo se torne letra morta é interpretando-o de forma a também não admitir a sua substituição por máquinas.

Os órgãos que integram o judiciário exercem importante papel na afirmação das garantias ao exercício do direito de greve. Cabe-lhe determinar a reintegração dos grevistas dispensados enquanto o seu contrato se encontrava suspenso em razão da adesão ao

497 ORGANIZAÇÃO INTERNACIONAL DO TRABALHO. Principios da la OIT sobre el derecho de huelga. Genebra: Organização Internacional do Trabalho, 2000, p. 41.

${ }^{498}$ Ibidem, p. 43. 
movimento grevista, determinar tutela inibitória para impedir a substituição dos trabalhadores grevistas por outros ou por máquinas, conceder, com base no artigo 659, IX, liminar destinada a impedir a transferência determinada pelo empregador, além de qualquer outra medida que vise assegurar o exercício do direito de greve pelo trabalhador e sancionar condutas antissindicais praticadas pelo empregador.

Um exemplo de medida que indiretamente visa assegurar o livre exercício do direito de greve, ainda que a posteriori, foi a proferida pela $1^{\text {a }}$ Turma do TRT da $1^{\text {a }}$ Região ao julgar o RO 02475-1999-042-03-00-0. Ao apreciar o aludido processo, o Regional referido sancionou a tentativa de uma empresa de imputar um cunho ilícito aos empregados que utilizam piquetes, condenando-a a indenizar o trabalhador por danos morais $^{499}$.

499 O Direito do Trabalho, em face da diferenciação socioeconômica e de poder entre empregador e empregado, reconheceu na greve um instrumento politicamente legítimo e juridicamente válido para permitir, ao menos potencialmente, a busca de um relativo equilíbrio entre esses seres, quando atuando coletivamente em torno de seus problemas trabalhistas mais graves, de natureza coletiva. O movimento paredista é notável instrumento de convencimento e pressão detido pelos obreiros. A participação pacífica em greve traduz-se em direito fundamental nas democracias e, nesse sentido, não pode ser inviabilizado pelo empregador com a adoção de medidas coercitivas que impeçam o movimento ou intimide o participante (art. 9º, CR/1988). Nesse sentido, a tentativa da empresa de imputar à estratégia de utilização de piquetes - mecanismos que, enquanto meios pacíficos de persuasão, são válidos e acolhidos como exercício legítimo de prerrogativa jurídica - um cunho ilícito, atribuindo ao empregado participante uma conduta criminosa (que, na verdade, não foi adotada), constitui prática lesiva à honra do trabalhador, gerando o direito à reparação pela ocorrência de danos morais. (TRT 3a Região RO 02475-1999-042-03-00-0 - Ac. 1 ${ }^{\text {a }}$ T., 23.7.07, Rel Juiz Maurício Godinho Delgado) 


\section{A TUTELA PREVENTIVA E SUAS LIMITAÇÕES}

Como bem observa Ronnie Preuss Duarte, o acesso à jurisdição garante, subsidiariamente, a efetivação dos direitos subjetivos e das posições jurídico-individuais. Negar o acesso à via jurisdicional equivaleria, portanto, à negação do próprio direito material em jogo. Este direito de acesso à justiça compreenderia não apenas o direito de acesso aos tribunais, como também o direito ao justo processo. A sua base fundamental consistiria propriamente no princípio da dignidade da pessoa humana, sendo ele também uma emanação do próprio Estado de Direito. Em suas palavras, não se pode falar em Estado Democrático de Direito sem que se garanta aos cidadãos, em sua plenitude, a possibilidade de, em igualdade de condições, socorrer-se dos tribunais para tutelar as respectivas posições jurídicas subjetivas ${ }^{500}$.

Sob este aspecto, e abstratamente falando, diante da possibilidade de conflitos entre o direito de greve e direitos fundamentais do empregador ou de terceiro, há que se franquer a estes a possibilidade de buscar em juízo a tutela de seus interesses.

Segundo salienta o doutrinador chileno Alejandro Romel Seguel, como princípio geral de direito a configuração do conteúdo da ação processual aponta para reconhecer que qualquer interesse legítimo ou direito subjetivo obtenha a proteção judicial. Poder-se-ia dizer que em relação a este direito existe como pauta reitora o princípio pro actione, em razão do qual os órgãos judiciais devem interpretar os diferentes requisitos e pressupostos processuais de um modo mais consentaneo com o direito constitucional a obter a proteção judicial dos direitos devendo se rechaçar in limine litis as teses rígidas ou formalistas que

\footnotetext{
${ }^{500}$ DUARTE, Ronnie Preuss. Garantia de acesso à Justiça: os direitos processuais fundamentais. Coimbra: Coimbra Editora, 2007, pp. 329/330.
} 
possam privar as pessoas de obter uma tutela judicial efetiva de seus direitos e interesses $\operatorname{legítimos}^{501}$.

Esta liberdade no exercício da ação se entende de melhor forma quando se repara que o nosso ordenamento jurídico consiste em um sistema de direito e não em um sistema de ações. A simples possibilidade de ajuizamento de ações principais ou cautelares inominadas denota que, no sistema processual brasileiro, a ação está concebida como um instrumento geral para a proteção jurídica, estando, portanto, alheia a enumerações em um catálogo ou lista de ações.

Marcus Orione Gonçalves Correia, após destacar que o exercício do poder constitucional de ação (art. $5^{\circ}$, inciso XXXV da CF) consubstancia uma das manifestações mais viscerais da cidadania, registra que até mesmo a ação individual apresenta esta conotação de participação política e de manutenção do Estado democrático de direito ${ }^{502}$. Referido autor destaca que a ação apresenta natureza de liberdade pública e de poder. Como liberdade pública na medida em que somente o exercício ou a possibilidade de exercício da ação restabelece o direito das leis, já que a sentença, na forma tradicionalmente concebida, dita, para a controvérsia, a lei. De maneira que a constitucionalização do direito de ação corresponde a um dos desejos mais íntimos do liberalismo, ou seja, a prevalência do governo das leis sobre o governo dos homens, além de representar o aparecimento de um poder judicial independente do poder político. Conclui asseverando que a leitura do texto constitucional vigente deve ser feita sempre no sentido de se fornecer maior eficácia a este poder - "com evidente prestigio a toda e qualquer interpretação que implique valorização da idéia de amplo acesso à justiça" ${ }^{503}$.

Ora, o poder de ação, segundo magistério de Candido Rangel Dinamarco, permite que as pessoas se façam ouvir sempre pelo Estado-juiz, quer tenham ou não tenham razão. Nessa mesma medida compromete-se o Estado a dar resposta a quem quer que lhe provoque o exercício da função jurisdicional, não lhe sendo lícito silenciar ante qualquer pedido, por mais absurdo e descabido que seja ${ }^{504}$.

\footnotetext{
${ }^{501}$ SEGUEL, Alejandro Romero. Curso de derecho procesal civil, tomo I: La acción y La protección de los derechos. Santiago: Editorial Jurídica de Chile, p. 69.

${ }^{502}$ CORREIA, Marcus Orione Gonçalves. Teoria e prática do poder de ação na defesa dos direitos sociais. São Paulo: LTr, 2002, p. 48.

${ }^{503}$ SEGUEL, Alejandro Romero. Op cit, p. 69.

${ }^{504}$ DINAMARCO, Candido Rangel. Execução civil. $5^{a}$ Ed. São Paulo: Malheiros, 1997, p.367.
} 
Sob esse aspecto há que se reconhecer que o ajuizamento de ações que visem coibir excessos ou buscar reparação por excessos cometidos durante movimentos paredistas não viola, por si só, o direito de greve. Não se pode deixar de ter em mente, contudo, que conteúdo da decisão proferida nessas ações pode, sim, implicar em injustificável obstaculização do direito de greve. O risco de afronta ao direito de greve é consideravelmente elevado quando a tutela ao direito fundamental que com ele se confronta é concedida de forma preventiva, no curso de uma ação que não se destinava a reparar o dano que já ocorreu, mas a impedir a prática, a continuação ou a repetição do ilícito.

Também é forçoso reconhecer que o direito de ação, assim como todos os demais direitos, pode ser exercido de forma abusiva. A postura de quem se vale ardilosamente da prerrogativa constitucional da inafastabilidade da jurisdição para fins ilícitos ou imorais, deve ser sempre sancionada. Não sem razão se considera litigante de má-fé os que, no Brasil, deduzem pretensão ou defesa contra texto expresso de lei ou fato incontroverso, alteram a verdade dos fatos, usam do processo para conseguir objetivo ilegal, procedem de modo temerário em qualquer incidente ou ato do processo e provocam incidentes manifestamente infundados, entre outras hipóteses, condutas puníveis com multa não excedente a um por cento sobre o valor da causa e condenação em indenizar a parte contrária dos prejuízos que esta sofreu, mais honorários advocatícios e todas as despesas que efetuou.

\subsection{TUTELA PREVENTIVA}

Os estudiosos da ciência processual, não apenas no Brasil, mas em todo o mundo, há muito perceberam que o modelo clássico que dividia a tutela jurisdicional em três possibilidades (declaratória, condenatória e constitutiva) não se mostrava adequado para a tutela de direitos. Desenvolveram-se então as tutelas preventivas, não destinadas a reparar o dano que já ocorreu, mas a impedir a prática, a continuação ou a repetição do ilícito.

Fala-se hoje, inclusive, na existência de um direito à tutela jurisdicional diferenciada. Segundo o jurista peruano Aldo Zela Villegas, o direito à tutela jurisdicional diferenciada deve ser reconhecido como um direito dos jurisdicionados em face do Estado. Em um primeiro momento seria um direito dirigido aos legisladores para que adotem e prevejam os mecanismos legais adequados para brindar uma tutela efetiva. Com isso o 
legislador deve estabelecer uma tutela eficaz particular que lhe seja inerente a cada tipo de direito, a oportunidade em que deva ser utilizada esta tutela e o conteúdo da mesma. Em um segundo momento, o direito à tutela diferenciada seria um direito dos jurisdicionados frente aos juízes. Aqueles não apenas teriam o direito à existência de diversos tipos de tutela e a escolher aquela que considerem mais efetiva, como também teriam o direito a que estes, obrigatoriamente, dessem uma tramitação adequada às pretensões que se apresentam perente ele $^{505}$.

Esta nova modalidade de tutela processual restou incorporada ao direito brasileiro, de forma geral, para qualquer obrigação de fazer ou não fazer, com a edição da Lei 10.444/02. Permitiu-se que, para prevenir danos, o juiz conceda liminarmente a tutela pretendida, impondo multa diária ao réu, determinando a busca e apreensão de coisas, desfazimento de obras e impedimento de atividade nociva, se necessário com requisição de força policial. Mesmo antes da incorporação da regra em questão, visualizavam-se formas de tutela preventiva em alguns procedimentos possessórios, quando se possibilitava o socorro do judiciário em caso, por exemplo, de esbulho.

Antes mesmo da referida alteração legislativa, a possibilidade e a necessidade de desenvolvimento de uma forma de tutela preventiva emanava do artigo $5^{\circ}, \mathrm{XXXV}$ da Constituição Federal, com a previsão de que "nenhuma lei excluirá da apreciação do Poder Judiciário lesão ou ameaça a direito". Como bem salientou Luiz Guilherme Marinoni:

se a própria Constituição afirma a inviolabilidade de determinados direitos e, ao mesmo tempo, diz que nenhuma lei poderá excluir da apreciação do Poder Judiciário 'ameaça a direito', não pode restar qualquer dúvida de que o direito de acesso à justiça (art. $5^{\circ}, \mathrm{XXXV}, \mathrm{CF}$ ) tem como corolário o direito à tutela efetivamente capaz de impedir a violação do direito.

Segundo o doutrinador chileno Alejando Romero Seguel, a tutela preventiva corresponde a uma especial forma de ação condenatória, através da qual se permite a adoção de medidas necessárias para evitar a consumação de um dano eventual. A base dogmática desta especial forma de proteção jurídica nasce no momento em que se aceita que, presentes certos pressupostos, os jurisdicionados possam solicitar ao órgão

\footnotetext{
505 VILLEGAS, Aldo Zela. La tutela preventiva de los derechos: como manifestación de la tutela
} diferenciada. Lima: Palestra Editores, 2008, p. 41/42. 
jurisdicional medidas de prevenção que impeçam ulteriores lesões patrimoniais ${ }^{506}$. De um modo geral, os mecanismos de tutela preventiva se caracterizam por atuar antes das formas clássicas, que põe ênfase nas sentenças condenatórias, especialmente indenizatórias ${ }^{507}$.

O pressuposto essencial para a tutela preventiva é a existência de um dano ou perigo que se busque evitar por esta via processual. A simples existência de uma ameaça de dano ainda não concretizado é uma situação que legitima este tipo de proteção jurisdicional $^{508}$.

Não se pode olvidar, todavia, que a ação inibitória, como ressalta Marinoni, "se volta contra a possibilidade do ilícito, ainda que se trate de repetição ou continuação. Assim, é voltada para o futuro e não para o passado ",509.

Ademais, a tutela inibitória "não requer nem mesmo a probabilidade do dano, contentando-se com a simples probabilidade de ilícito (ato contrário ao direito)”. Afinal, imaginar que uma tutela deste gênero dedica-se a inibir o dano implica na suposição de que nada existe antes dele que possa ser qualificado como ilícito civil. E como o dano é uma consequência eventual do ato contrário ao direito eles (o dano e o ato contrário ao direito) podem e devem ser mais adequadamente $\operatorname{protegidos}^{510}$. E remata o jurista paranaense:

Assim, por exemplo, se há um direito que exclui um fazer, ou uma norma definindo que algo não pode ser feito, a mera probabilidade de ato contrário ao direito - e não de dano - é suficiente para a tutela jurisdicional inibitória ${ }^{511}$.

Percebe-se, outrossim, que, em se tratando de tutela inibitória, o autor não precisa, via de regra, alegar dano e o réu está impedido de discuti-lo. A prova restringe-se ao ilícito $^{512}$.

Quando, entretanto, há identidade cronológica entre o ato contrário ao direito e o dano, pois ambos podem acontecer no mesmo instante, a probabilidade do dano constitui o objeto da cognição do juiz e, assim, o autor deve aludir a ele e o réu pode discuti-lo ${ }^{513}$.

\footnotetext{
${ }^{506}$ SEGUEL, Alejandro Romero. Curso de derecho procesal civil, tomo I: La acción y La protección de los derechos. Santiago: Editorial Jurídica de Chile, p. 46.

${ }^{507}$ SEGUEL, Alejandro Romero. Curso de derecho procesal civil, tomo I: La acción y La protección de los derechos. Santiago: Editorial Jurídica de Chile, p. 46.

508 Ibidem.

${ }^{509}$ MARINONI, Luiz Guilherme. Técnica processual e tutela dos direitos. São Paulo: RT, 2004, p. 255;

${ }^{510}$ Ibidem.

${ }^{511}$ Ibidem, p. 255/256.

512 Ibidem.
} 
Diante da amplitude do direito de ação, que engloba também, como já salientado as tutelas preventivas, nada impede que, vislumbrando ameaça de dano ao patrimônio da empresa ou obstáculos ao trabalho dos não grevistas, responsabilidade sua em razão do dever de fornecer trabalho que lhe é imposto pelo contrato de emprego, o empregador busque socorro judicial antes mesmo da deflagração do movimento paredistas. Este direito não lhe pode ser negado. O êxito de sua pretensão, contudo, não se lhe pode garantir.

\subsection{TUTELA INIBITÓRIA NO PROCESSO DO TRABALHO}

O processo do trabalho é um campo fértil para a utilização da tutela inibitória diante do expressivo número de situações de ilícitos potencialmente geradores de dano. A própria exigência de ajuizamento de inquérito para apuração de falta grave cometida por dirigente sindical é, conforme entendimento da OIT, um mecanismo de caráter preventivo para proteger a atividade sindical. Ele não integra, contudo, o conceito de tutela judicial preventiva por ser ajuizado pela parte que abstratamente ameaça o direito tutelado, como se fosse um pedido de autorização prévio para cometer o ato, e não por quem precisa de proteção. Ao impossibilitar que o liame empregatício seja desfeito por iniciativa unilateral do empregador, sem prévia autorização judicial, referida medida previne atos antissindicais. Mas de tutela preventiva não se trata na medida em que não é a parte ameaçada que se socorre dela para evitar a consumação de um dano.

Há, em verdade, uma situação de tutela inibitória expressamente prevista no texto da Consolidação das Leis do Trabalho. Trata-se da medida liminar destinada a impedir a transferência determinada pelo empregador (Art. 659, IX). Esta, contudo, seguramente não é a única hipótese em que se pode fazer uso deste importante instrumento. Poder-se-ia, por exemplo, imaginar a utilização de medidas do gênero para impedir que determinado empregador exigisse prestação de serviços em locais com condições precárias de segurança, para impedi-lo de determinar o trabalho em sobrejornada de forma unilateral fora das hipóteses do artigo 61 da Consolidação das Leis do Trabalho (CLT).

Há que se lamentar, todavia, o fato de o nosso ordenamento jurídico haver sido organizado de uma forma a desestimular este tipo de ação. A falta de uma efetiva forma de proteção contra a dispensa arbitrária fez da tutela repressiva a regra geral, quase absoluta,

${ }^{513}$ Ibidem. 
das demandas individuais na Justiça do Trabalho. Diante do dilema entre buscar uma medida judicial individual e correr o risco de perder o emprego e assumir o risco de sofrer algum dano em razão de ilícito praticado pelo empregador, os empregados acabam, naturalmente, por optar pela segunda hipótese. Em um regime capitalista como o nosso, o emprego, bem muitas vezes escasso, acaba se sobrepondo em importância a outros bens como a integridade física. Não é pequeno o contingente de trabalhadores que se submetem a labor em condições reconhecidamente nocivas à sua saúde ou que põe sua vida em risco, em troca de adicionais salariais praticamente irrisórios. Com isso, os trabalhadores findam por somente buscar socorro judicial após a cessação do contrato de trabalho, hipótese em que o dano já foi consumado e, por conseguinte, o que se busca é uma condenação do empregador a repará-lo.

Além daquela elencada no artigo 659, IX da CLT, que pode perfeitamente ser utilizada para impedir transferência de dirigente sindical que visava enfraquecer movimento grevista, outras hipóteses de tutela preventiva podem ser extraídas da Lei 7.783/89. É possível, por exemplo, fazer uso de tutela preventiva para evitar a substituição de trabalhadores grevistas por outros trabalhadores ou por máquinas. Seria o caso, por exemplo, de, diante da discordância do empregador acerca do efetivo cumprimento da obrigação de manutenção de equipes de empregados com o propósito de assegurar os serviços cuja paralisação resulte em prejuízo irreparável, pela deterioração irreversível de bens, e da ameaça de substituição dos grevistas, a representação de trabalhadores postular tutela preventiva para evitar que esta se concretize.

Outra hipótese de tutela preventiva para garantir o exercício da greve seria a concessão de liminar inibindo a rescisão contratual dos trabalhadores grevistas

É preciso reconhecer ainda que não é apenas o empregado, hipossuficiente na relação laboral, que pode valer-se do judiciário para tentar impedir que uma conduta ilícita de outrem venha a causar-lhe danos. O empregador também poderá buscar esse tipo de tutela, por também lhe ser assegurado o direito de ação.

Advoga-se, contudo, e esta é uma das teses defendidas neste trabalho, a ideia de que cognição judicial deve ser sempre inclinada para a solução asseguradora do exercício do direito de greve. Cria-se, assim, uma maior propensão para o deferimento das ações postuladas pelos grevistas e por sua representação para garantir a manifestação e para o 
indeferimento das ações que visem tutelar direitos em rota de colisão com o direito de greve. Propõe-se aqui uma técnica de hexegese segundo a qual sempre que houver dúvida deve-se adotar a solução que melhor assegure o exercício do direito de greve.

Esse desequilíbrio se justifica pela própria natureza conflitiva do direito de greve que o coloca sempre e inevitavelmente em confronto com outros direitos fundamentais. Se não se admitir esse favorecimento hermenêutico ao exercício da greve, e se toda vez que se fizer uma ponderação de valores a opção for pela tutela do direito supostamente ameaçado de lesão, dificilmente sobreviverá um movimento paredista.

\subsection{INADMISSIBILIDADE DE TUTELA PREVENTIVA}

A redação do artigo $5^{\circ}, \mathrm{XXXV}$ da Constituição, ao estatuir que a lei não excluirá da apreciação do Poder Judiciário lesão ou ameaça a direito, evidencia, com clareza solar, a possibilidade de se postular preventivamente para evitar que seu direito venha a ser efetivamente violado. É forçoso reconhecer, contudo, que o princípio da inafastabilidade da jurisdição consagra a impossibilidade de o legislador infraconstitucional impedir determinada ameaça de lesão a direito de ser apreciada pelo Poder Judiciário. Isso não significa, evidentemente, que não existam situações em que a tutela preventiva em questão fique impossibilitada pela própria natureza do direito em confronto com ela.

Imagine-se, por exemplo, um pleito destinado a impedir alguém de exercer sua atividade intelectual, artística, científica e de comunicação, em razão de ela ameçar a honra a imagem de outrem, situação que coloca em flagrante confronto direitos fundamentais consagrados no artigo $5^{\circ}$, IX e $\mathrm{X}$, respectivamente. Se a tutela for deferida de forma preventiva, os direitos consagrados naquele inciso restarão completamente esvaziados. A tutela preventiva em questão acabaria funcionando na prática como uma medida de censura, como uma espécie de licença, ambas expressamente vedadas pelo preceito constitucional em que questão.

Isso não significa que a intimidade, a vida privada, a honra e a imagem das pessoas devam sucumbir sempre que estiver em confronto com a liberdade de expressão da atividade intelectual, artística, científica e de comunicação. Significa apenas que a tutela concedida pelo judiciário não poderá, neste caso, ser preventiva, precisará efetivamente ser repressiva. Essa, aliás, parece ser a solução desejada pelo próprio legislador constituinte 
derivado ao afirmar a liberdade de expressão da atividade intelectual, artística, científica e de comunicação, "independentemente de censura ou licença" e, no dispositivo seguinte, considerar inviolável a intimidade, a vida privada, a honra e a imagem das pessoas, "assegurado o direito a indenização pelo dano material ou moral decorrente de sua violação".

Em interessante estudo publicado na rede mundial de computadores, Douglas Admiral Louzada, enfrenta a discussão acerca do choque entre a liberdade de expressão e o direito a honra e a imagem de sujeitos de investigação criminal, fazendo alusão a uma criticada decisão do desembargador Jirair Meguerian, do Tribunal Regional Eleitoral do Distrito Federal, poibindo, em 23 de outubro de 2002, o jornal Correio Braziliense de veicular matérias que contivessem conteúdo de determinadas gravações telefônicas interceptadas por ordem judicial. Estas gravações referiam-se a conversas entre o então governador do Distrito Federal, Joaquim Roriz, e os irmãos Passos, acusados de grilagem de terras públicas, ou seja, apropriação de terras alheias mediante falsas escrituras públicas $^{514}$.

Acolhendo o pedido de Joaquim Roriz, candidato à reeleição naquele ano, referido magistrado determinou a "busca e apreensão, com arrombamento ou entrada compulsória, na sede, se houver necessidade, de todos os exemplares do jornal Correio Braziliense". Noticiou-se, à época, que um oficial de Justiça teria acompanhado a impressão do jornal para apreender todos os exemplares da edição caso algum trecho das fitas viesse a ser publicado $^{515}$.

Entre os que se manifestariam contrariamente a decisão cabe mencionar o jurista paulista Luís Flávio Gomes, que declarou, à época, que "A decisão que submeteu o jornal à censura prévia é inconstitucional e resultado do excesso de cautela do juiz. Não se pode amordaçar um jornal por simples suspeita de ocorrência de um delito". O Ministro Marco Aurélio Mello, então presidente do Supremo do Tribunal Federal, foi ainda mais longe e afirmou textualmente que "Em matéria de liberdade de expressão, é proibido proibir" ${ }^{516}$.

\footnotetext{
${ }^{514}$ LOUZADA, Douglas Admiral. Os contornos do direito de liberdade de expressão sob a ótica da teoria jurídica liberal de Dworkin. Jus Navigandi, Teresina, ano 14, n. 2244, 23 ago. 2009. Disponível em: <http://jus.com.br/revista/texto/13385>. Acesso em: 31 dez. 2011.

${ }^{515}$ Ibidem.

${ }^{516}$ Apud LOUZADA, Douglas Admiral. Op cit.
} 
Essa posição, em verdade, apenas corroborou o entendimento por ele adotado em diversos julgamentos anteriores sobre casos semelhantes, de que a liberdade de imprensa seria um dos pilares inabaláveis da Constituição, inatacável por mecanismos de censura (mecanismos, aliás, proibidos de forma expressa pela própria Constituição). Em sua opinião os meios de comunicação podem publicar o que quiserem, sujeitando-se, porém, a responder ações de natureza penal (no caso de calúnia, injúria e difamação, por exemplo) e civil (indenização por ofensas à imagem, por exemplo) ${ }^{517}$.

Sérgio Ricardo de Souza adota entendimento diverso. Em sua opinião, o choque de valores entre a dignidade da pessoa humana investigada e a liberdade de informação jornalística configura uma colisão de princípios que deve ser solucionada pela utilização da ponderação de valores, através da análise do valor mais relevante em cada situação, o que se alcança pela aplicação do princípio da proporcionalidade. Aduz ainda que dentro do critério de ponderação orientada axiologicamente pelo princípio da proporcionalidade, a análise do interesse público ou social no conhecimento do fato a ser noticiado se apresenta como fator preponderante na tarefa do intérprete, quando tenha que estabelecer qual o valor que deve ser preservado no caso concreto em que se verifica a colisão entre a dignidade da pessoa humana investigada e a liberdade de informação jornalística. Afirma, por fim, que o Judiciário estaria legitimado para, em decorrência da provocação da parte interessada, e por força do princípio da inafastabilidade da jurisdição, conhecer da colisão envolvendo referidos princípios, solucioná-lo, não só definitivamente, como cautelarmente $^{518}$.

Situação similar pode ser identificada em relação ao direito de greve previsto no artigo $9^{\circ}$ da Constituição Federal. Assim como a liberdade de expressão não pode ser objeto de censura ou de exigência de licença prévia, a tese aqui advogada é a de que o direito de greve, tal qual previsto na Constituição, não comporta, em regra, intervenção prévia do Poder Judiciário salvo para assegurar o atendimento das necessidades inadiáveis da comunidade. A Carta Magna admite apenas intervenção posterior para disciplinar os abusos cometidos no curso do movimento grevista, mediante aplicação das sanções previstas em lei. O direito de greve não poderia, outrossim, ter, em geral, o seu âmbito

\footnotetext{
${ }^{517}$ Apud LOUZADA, Douglas Admiral. Os contornos do direito de liberdade de expressão sob a ótica da teoria jurídica liberal de Dworkin. Jus Navigandi, Teresina, ano 14, n. 2244, 23 ago. 2009. Disponível em: <http://jus.com.br/revista/texto/13385>. Acesso em: 31 dez. 2011.

${ }^{518}$ SOUZA, Sérgio Ricardo de. Controle judicial dos limites constitucionais à liberdade de imprensa. Rio de Janeiro: Lumen Juris, 2008, p. 192.
} 
restringido por meio de tutela preventiva, salvo para assegurar o atendimento das necessidades inadiáveis da coletividade.

Não se afigura adequado afirmar que determinado direito, liberdade ou garantia constitucional é insuscetível de limitação por tutela preventiva à outro direito. O próprio Supremo Tribunal Federal admitiu restrição à liberdade de expressão no paradigmático caso em que se discutiu a proibição de publicação de livros com conteúdo antisemita. $\mathrm{O}$ excelso Pretório consignou, no julgamento em questão, que as liberdades públicas não são incondicionais, devendo por isso ser exercidas de maneira harmônica, observados limites definidos na própria Constituição Federal que assevera que o preceito fundamental da liberdade de expressão não consagra o direito à incitação ao racismo, dado que um direito individual não pode constituir-se em salvaguarda de condutas ilícitas, como sucede com os delitos contra a honra ${ }^{519}$.

519 HABEAS-CORPUS. PUBLICAÇ̃̃O DE LIVROS: ANTI-SEMITISMO. RACISMO. CRIME IMPRESCRITÍVEL. CONCEITUAÇÃ̃O. ABRANGÊNCIA CONSTITUCIONAL. LIBERDADE DE EXPRESSÃO. LIMITES. ORDEM DENEGADA. 1. Escrever, editar, divulgar e comerciar livros "fazendo apologia de idéias preconceituosas e discriminatórias" contra a comunidade judaica (Lei 7716/89, artigo 20, na redação dada pela Lei 8081/90) constitui crime de racismo sujeito às cláusulas de inafiançabilidade $\mathrm{e}$ imprescritibilidade (CF, artigo $5^{\circ}$, XLII). 2. Aplicação do princípio da prescritibilidade geral dos crimes: se os judeus não são uma raça, segue-se que contra eles não pode haver discriminação capaz de ensejar a exceção constitucional de imprescritibilidade. Inconsistência da premissa. 3. Raça humana. Subdivisão. Inexistência. Com a definição e o mapeamento do genoma humano, cientificamente não existem distinções entre os homens, seja pela segmentação da pele, formato dos olhos, altura, pêlos ou por quaisquer outras características físicas, visto que todos se qualificam como espécie humana. Não há diferenças biológicas entre os seres humanos. Na essência são todos iguais. 4. Raça e racismo. A divisão dos seres humanos em raças resulta de um processo de conteúdo meramente político-social. Desse pressuposto origina-se o racismo que, por sua vez, gera a discriminação e o preconceito segregacionista. 5. Fundamento do núcleo do pensamento do nacional-socialismo de que os judeus e os arianos formam raças distintas. Os primeiros seriam raça inferior, nefasta e infecta, características suficientes para justificar a segregação e o extermínio: inconciabilidade com os padrões éticos e morais definidos na Carta Política do Brasil e do mundo contemporâneo, sob os quais se ergue e se harmoniza o estado democrático. Estigmas que por si só evidenciam crime de racismo. Concepção atentatória dos princípios nos quais se erige e se organiza a sociedade humana, baseada na respeitabilidade e dignidade do ser humano e de sua pacífica convivência no meio social. Condutas e evocações aéticas e imorais que implicam repulsiva ação estatal por se revestirem de densa intolerabilidade, de sorte a afrontar o ordenamento infraconstitucional e constitucional do País. 6. Adesão do Brasil a tratados e acordos multilaterais, que energicamente repudiam quaisquer discriminações raciais, aí compreendidas as distinções entre os homens por restrições ou preferências oriundas de raça, cor, credo, descendência ou origem nacional ou étnica, inspiradas na pretensa superioridade de um povo sobre outro, de que são exemplos a xenofobia, "negrofobia", "islamafobia" e o anti-semitismo. 7. A Constituição Federal de 1988 impôs aos agentes de delitos dessa natureza, pela gravidade e repulsividade da ofensa, a cláusula de imprescritibilidade, para que fique, ad perpetuam rei memoriam, verberado o repúdio e a abjeção da sociedade nacional à sua prática. 8. Racismo. Abrangência. Compatibilização dos conceitos etimológicos, etnológicos, sociológicos, antropológicos ou biológicos, de modo a construir a definição jurídicoconstitucional do termo. Interpretação teleológica e sistêmica da Constituição Federal, conjugando fatores e circunstâncias históricas, políticas e sociais que regeram sua formação e aplicação, a fim de obter-se o real sentido e alcance da norma. 9. Direito comparado. A exemplo do Brasil as legislações de países organizados sob a égide do estado moderno de direito democrático igualmente adotam em seu ordenamento legal punições para delitos que estimulem e propaguem segregação racial. Manifestações da Suprema Corte NorteAmericana, da Câmara dos Lordes da Inglaterra e da Corte de Apelação da Califórnia nos Estados Unidos 
No caso referido concedeu-se uma tutela preventiva, inibitória, evitando a consumação do dano. Essa tutela preventiva só foi permitida porque os instrumentos capazes de produzir o dano, os livros, já estavam diagramados e pontos para ser comercializados. O mesmo não pode ser dito em relação a uma lesão que se supõe que será causada por um movimento grevista. Não se pode considerar que o simples fato de haver uma aglomeração de trabalhadores deva ser considerado "um instrumento" causador do dano futuro.

Não é prudente, entretanto, afirmar taxativamente que não se pode conceder tutela preventiva, sobretudo tutela inibitória, para restringir o direito de greve. Uma hipótese de pouca probabilidade de verificação na prática seria o descobrimento de documentos que comprovam um plano dos grevistas para danificar as principais máquinas da empresa por alguma razão qualquer. É extremamente plausível, em verdade é até mesmo necessário, que o empregador ingresse com uma ação inibitória, além de outras medidas legais cabíveis, para impedir esse dano. Essa situação, entretanto, é absolutamente extraordinária. Não pode jamais ser tida como regra. Não deve balizar o entendimento acerca da concessão de tutela preventiva quando em discussão o exercício do direito de greve.

que consagraram entendimento que aplicam sanções àqueles que transgridem as regras de boa convivência social com grupos humanos que simbolizem a prática de racismo. 10. A edição e publicação de obras escritas veiculando idéias anti-semitas, que buscam resgatar e dar credibilidade à concepção racial definida pelo regime nazista, negadoras e subversoras de fatos históricos incontroversos como o holocausto, consubstanciadas na pretensa inferioridade e desqualificação do povo judeu, equivalem à incitação ao discrímen com acentuado conteúdo racista, reforçadas pelas conseqüências históricas dos atos em que se baseiam. 11. Explícita conduta do agente responsável pelo agravo revelador de manifesto dolo, baseada na equivocada premissa de que os judeus não só são uma raça, mas, mais do que isso, um segmento racial atávica e geneticamente menor e pernicioso. 12. Discriminação que, no caso, se evidencia como deliberada e dirigida especificamente aos judeus, que configura ato ilícito de prática de racismo, com as conseqüências gravosas que o acompanham. 13. Liberdade de expressão. Garantia constitucional que não se tem como absoluta. Limites morais e jurídicos. $\mathrm{O}$ direito à livre expressão não pode abrigar, em sua abrangência, manifestações de conteúdo imoral que implicam ilicitude penal. 14. As liberdades públicas não são incondicionais, por isso devem ser exercidas de maneira harmônica, observados os limites definidos na própria Constituição Federal $\left(\mathrm{CF}\right.$, artigo $5^{\circ}, \S 2^{\circ}$, primeira parte). O preceito fundamental de liberdade de expressão não consagra o "direito à incitação ao racismo", dado que um direito individual não pode constituir-se em salvaguarda de condutas ilícitas, como sucede com os delitos contra a honra. Prevalência dos princípios da dignidade da pessoa humana e da igualdade jurídica. 15. "Existe um nexo estreito entre a imprescritibilidade, este tempo jurídico que se escoa sem encontrar termo, e a memória, apelo do passado à disposição dos vivos, triunfo da lembrança sobre o esquecimento". No estado de direito democrático devem ser intransigentemente respeitados os princípios que garantem a prevalência dos direitos humanos. Jamais podem se apagar da memória dos povos que se pretendam justos os atos repulsivos do passado que permitiram e incentivaram o ódio entre iguais por motivos raciais de torpeza inominável. 16. A ausência de prescrição nos crimes de racismo justifica-se como alerta grave para as gerações de hoje e de amanhã, para que se impeça a reinstauração de velhos e ultrapassados conceitos que a consciência jurídica e histórica não mais admitem. Ordem denegada.(HC 82424, Relator(a): Min. MOREIRA ALVES, Relator(a) p/ Acórdão: Min. MAURÍCIO CORRÊA, Tribunal Pleno, julgado em 17/09/2003, DJ 19-03-2004 PP-00017 EMENT VOL-02144-03 PP-00524) 
Embora entenda que a intervenção judicial prévia não pode ser enquadrada na definição tradicional de censura, Tatiana Stroppa entende dever ela ser encarada como uma medida excepcionalíssima e somente aceitável quando, depois de realizada a ponderação de bens assentada sob o princípio da proporcionalidade em sentido amplo, revelar-se como a única forma de impedir uma lesão desnecessária e injustificada, de forma que, em regra, os danos ou agravos sejam apurados e ressarcidos posteriormente à divulgação da notícia ou da opinião ${ }^{520}$.

Aplicando por analogia o mesmo entendimento, podemos concluir que a intervenção judicial prévia em manifestações grevístas deve ser encarada como medida excepcionalíssima, somente aceitável nas raríssimas hipóteses em que estiver presente efetivo risco de violação a outro direito fundamental, cuja sanção a posteriori seja absolutamente impossível. O direito de greve se apresenta, portanto, como fator preponderante na tarefa do intérprete de estabelecer qual o valor que deve ser preservado no caso concreto.

${ }^{520}$ STROPPA, Tatiana. As dimensões constitucionais do direito de informação e o exercício da liberdade de informação jornalística. Belo Horizonte: Editora fórum, 2010, p. 212. 


\section{AÇÕES RELACIONADAS COM O EXERCÍCIO DA GREVE}

Apesar de optar expressamente por não apresentar conclusão acerca da incompatibilidade histórica e jurídica entre a regulação jurisdicional de conflitos coletivos e direito de greve, Antonio Rodrigues de Freitas Júnior argumenta que no corporativismo de Estado brasileiro, a combinação entre regulação jurisdicional e supressão ou delimitação excessiva do direito de greve desloca o destinatário da argumentação (originariamente restrita aos próprios sujeitos da relação coletiva) para o Poder Judiciário, que passa a ser interlocutor privilegiado na tarefa persuasória. Em sua abalizada opinião, se de um lado pudessemos admitir que esta engenharia institucional tende a reduzir o aparecimento de medidas conflitivas, por outra, pelas mesmas razões, teríamos de reconhecer que ela compromete a autenticidade do discurso das partes e concorre para a sobreposição da ética de convicção à ética de responsabilidade, no desenvolvimento das relações negociais primárias $^{521}$.

Referido autor critica ainda o fato de, além de poder estabelecer normas e condições de trabalho e declarar a legalidade ou ilegalidade da greve, assistir à Justiça do Trabalho a função de tornar implicitamente ilegais todas as greves deflagradas na vigência das sentenças normativas que profere ${ }^{522}$.

O modelo de dissídio coletivo no Brasil inspira-se no modelo corporativista italiano. Segundo Wilson de Souza Campos Batalha, "Na Itália, sob o regime fascista, as greve e os lock-outs eram punidos, confiando-se à magistratura do trabalho a incumbência

521 FREITAS JÚNIOR, Antonio Rodrigues de. Sindicato: domesticação e ruptura: um estudo da representação sindical no direito brasileiro. São Paulo: Ordem dos Advogados do Brasil, Departamento Editorial, 1989, p. 161.

${ }^{522}$ Ibidem, p. 162. Embora aludidas afirmações tenha sido dirigidas ao texto constitucional de 1967 e à Lei 4.330/64, a sua validade é inegável haja vista não ter havido, quanto a este ponto alteração substancial no modelo brasileiro. 
de dirimir os dissídios coletivos, que surgiram como substitutivos das greves e dos lockouts ${ }^{\prime 523}$. Neste regime, o recurso à autotutela era vedado, facultando-se aos atores sociais recorrer ao judiciário quando não conseguisse chegar a uma solução consensual com a parte contrária.

O mesmo Wilson de Souza Campos Batalha destaca, em outra obra, que o efetivo reconhecimento do direito de greve somente ocorreu na Itália após a destruição do regime corporativo fascista, mais precisamente após o Decreto-Lei n. 721, de 9.9.43 haver suprimido o ordenamento corporativo e, por via de consequência, posto fim à competência da Justiça do Trabalho como órgão competente para dirimir dissídios coletivos. O coroamento, contudo, teria ocorrido com a consagração do diritto di sciopero no artigo 40 da Constituição de $1947^{524}$.

O Brasil incorporou bem a idéia adotada na Itália Corporativista de que a Justiça especializada seria suficiente para substituir o direito de greve. Uma boa evidência disso é o fato de Francisco Campos haver consignado, na exposição de motivos do Código Penal Brasileiro, que "Para dirimir as contendas entre o trabalho e o capital, foi instituída a Justiça do Trabalho, tornando-se incompatível com a nova ordem política o exercício arbitrário das próprias razões por parte de empregados e empregadores" ${ }^{\text {"525 }}$.

Paulo Garcia destaca, em sua obra, haver existido no Brasil uma corrente sustentando a incompatibilidade entre a greve e a Justiça do Trabalho. Segundo seus defensores, não se poderia falar em direito de greve enquanto existisse uma Justiça com finalidade exclusiva de dirimir as questões entre empregados e empregadores ${ }^{526}$.

Todavia, o mesmo autor discorda da corrente que vê incompatibilidade entre o direito de greve e a existência de uma Justiça do Trabalho. Em sua opinião, a greve pode perfeitamente coexistir com a Justiça do Trabalho. A esta poderia a lei afetar competência - em certos casos - para dirimir o conflito, depois dele manifestado, sem que isto implicasse em paradoxo ${ }^{527}$. Não se poderia dar prevalência ao Judiciário sobre a greve. A

\footnotetext{
${ }^{523}$ BATALHA, Wilson de Souza Campos. Tratado de direito judiciário do trabalho. São Paulo: LTr, 1985, p. 677.

${ }_{524}$ BATALHA, Wilson de Souza Campos. Sindicatos, sindicalismo. São Paulo: LTr, 1992, p.211.

${ }^{525}$ Apud BATALHA, Wilson de Souza Campos. Tratado de direito judiciário do trabalho. São Paulo: LTr, 1985 , p. 683.

${ }^{526}$ GARCIA, Paulo. Direito de greve. Rio de Janeiro: Edições trabalhistas s.a, 1961, p. 83.

${ }^{527}$ Ibidem, p. 85
} 
existência de uma justiça especializada não poderia anular um direito constitucionalmente $\operatorname{assegurado}^{528}$. A greve foi constitucionalmente reconhecida em favor do trabalhador e, portanto, a ele compete dizer se pretende se valer desse recurso ou se deseja submeter suas pretensões à apreciação do órgão julgador ${ }^{529}$.

No Brasil a primeira norma a tratar deste mecanismo de solução de conflitos coletivos de trabalho foi o Decreto 21.396, de 12 de maio de 1932, que instituiu Comissões Mistas de Conciliação, estabelecendo o sistema de arbitragem facultativa para os dissídios coletivos. Consoante dispunha o aludido decreto, verificada a impossibilidade de conciliação, o Presidente da Comissão proporia às partes submeter o litígio à juízo arbitral. Recusada por uma das partes, ou por ambas, as propostas de submissão ao juízo arbitral, os autos seriam remetidos ao Ministério do Trabalho, ou à autoridade que representasse o Ministro que, conhecendo dos motivos da recusa, poderia nomear uma comissão especial que, sobre o dissídio, proferisse laudo ${ }^{530}$.

O anteprojeto de organização da Justiça do Trabalho, apresentado à Câmara dos Deputados pelo Presidente da República, em 1937, durante, portanto, a vigência da Constituição de 1934, conferia à Justiça do Trabalho competência normativa. Nele Agamenon Magalhães salientava ser indispensável a arbitragem obrigatória, como o único meio eficaz para impedir as greves e os lock-outs ${ }^{531}$.

Em 1943, ou seja, pouco tempo depois, o Decreto-lei n. 5.821, de 16 de setembro de 1943, determinou que os dissídios coletivos durante o estado de guerra, só poderiam ser iniciados pelos sindicatos, mediante prévia audiência do Ministro do Trabalho, Indústria e Comércio, que apreciaria o problema de sua oportunidade ${ }^{532}$. Evidencia-se, com essa norma, a acentuada preocupação em evitar que as reivindicações de trabalhadores, mesmo quando judiciarizadas e não buscadas diretamente, criassem algum tipo de inconveniente para os poderes estatais.

Batalha, contudo, não identifica na interferência do Estado em movimentos paredistas apenas aspectos negativos. Após ressaltar que as greves que sucederam a

\footnotetext{
${ }^{528}$ GARCIA, Paulo. Direito de greve. Rio de Janeiro: Edições trabalhistas s.a, 1961, p. 86.

529 Ibidem, p. 87.

530 BATALHA, Wilson de Souza Campos. Tratado de direito judiciário do trabalho. São Paulo: LTr, 1985, p. 682 .

531 Ibidem, p. 683.

532 Ibidem, p. 684.
} 
Conferência de Chapultepec, que consagrou o direito de greve, criaram um ambiente de intranquilidade realmente nocivo, referido autor afirma que "a essa época foi decisiva a influência benéfica da Justiça do Trabalho, a harmonizar as classes e a debelar os movimentos paredistas, num esforço conciliatório deveras apreciável e que jamais será esquecido na história de nossas instituições judiciárias" ${ }^{533}$.

Os anos se passaram e a idéia de que a intervenção do judiciário no movimento grevista é positiva parece ainda presente no inconsciente coletivo da população brasileira. É essa, pelo menos, a conclusão que se pode extrair da intervenção jurisdicional na greve dos aeronautas no final de 2010 em que, para evitar os transtornos que seriam causados aos usuários dos serviços de transporte aéreo, o judiciário efetivamente impediu os integrantes da aludida categoria de pressionar, mediante organização de um movimento grevista, seu empregador a atender as suas reivindicações.

Enquanto na maioria dos países do mundo o reconhecimento da greve como um direito levou ao fim dos procedimentos judicionais eventualmente existentes para solucionar os conflitos coletivos, no Brasil adotou-se uma solução curiosa, para não dizer paradoxal. Percebendo que não poderia repudiar o direito de greve, em face do compromisso assumido com a comunidade internacional, mas disposto a não suprimir a competência normativa dos tribunais do trabalho, que nos dizeres de Batalha "tão profícuos resultados havia apresentado nos anos anteriores", o legislador brasileiro procurou conciliar os dois institutos, "tarefa árdua e inçada de dificuldades quase indisponíveis" ${ }^{534}$. Em uma de suas obras, Batalha chegou a afirmar textualmente que:

o reconhecimento do direito de greve ao lado da manutenção do poder normativo da Justiça do Trabalho, resquício da magistratura del lavoro do fascismo, embora em clima político assaz diverso, constituiu problema que aos legisladores se lhes antolhava como extremamente difícil em sua conciliação ${ }^{535}$.

A primeira tentativa, segundo Batalha desastradamente duradoura, de harmonizar o dissídio coletivo com o direito de greve foi o Decreto-lei n. 9.070, de 15/03/46. Esta norma estipulou que o direito de greve só deve ser reconhecido depois de esgotados todos os meios legais para a solução do dissídio e distinguiu as atividades fundamentais e as

\footnotetext{
533 BATALHA, Wilson de Souza Campos. Tratado de direito judiciário do trabalho. São Paulo: LTr, 1985, p. 684 .

534 Ibidem, p. 684/685.

${ }^{535}$ BATALHA, Wilson de Souza Campos. Sindicatos, sindicalismo. São Paulo: LTr, 1992, p.215.
} 
acessórias, estipulando que nas primeiras, a greve e o lock-out constituir-se-iam em falta grave, mas nas segundas seriam admitidos depois de ajuizado o dissídio, sujeitando-se, contudo, as partes às consequências de sua atitude, em particular a perda de seus salários ou seu pagamento. O direito de instauração do dissídio coletivo não ficou, contudo, reservado aos sindicatos.

Como o mencionado decreto lei foi promulgado pouco antes do advento da Constituição de 1946, a sua constitucionalidade foi naturalmente questionada após o início da vigência desta. Houve quem sustentasse que o direito de greve reconhecido na nova Constituição deveria ser tido por irrestrito enquanto não fosse elaborada a nova lei de greve. Essa tese, contudo, não foi acolhida. Como bem pontuou Wilson de Souza Campos Batalha, “ enquanto nova lei não se elaborasse, é evidente que continuariam em vigor os dispositivos legais anteriores sobre o assunto, desde que se não atritassem com o preceito constitucional”. E o Decreto-lei n. 9.070 havia consagrado o direito de greve, apenas limitando-o pelas exigências do interesse coletivo ${ }^{536}$.

A resistência do poder público brasileiro em acabar com o dissídio de greve persistiu. Batalha destaca que vários projetos de leis foram elaborados com o intuito de conciliar o direito de greve com a competência normativa dos tribunais do trabalho. Ao anteprojeto do Deputado Gurgel do Amaral destacava que a greve não seria permitida para obter modificação das convenções coletivas, sentenças coletivas ou acordos homologados pela Justiça do Trabalho, enquanto em vigor. Segundo os seus termos caberia aos trabalhadores, nos casos em que a greve fosse permitida, escolher, em plebiscito, entre a greve e o dissídio coletivo. O empregado que não se conformasse com a decisão coletiva poderia afastar-se recebendo a metade da indenização legal, salvo em período de guerra ${ }^{537}$.

Outro projeto, este elaborado pela Comissão Permanente de Legislação Social do Ministério do Trabalho, estipulou que a greve só seria permitida por motivos inerentes ao trabalho, desde que pacífica e depois de prévio aviso. Nas atividades fundamentais seria obrigatória a intervenção da Justiça do Trabalho - instaurando-se o dissídio coletivo, e a sentença transitada em julgado poria termo à greve ${ }^{538}$.

\footnotetext{
${ }^{536}$ BATALHA, Wilson de Souza Campos. Tratado de direito judiciário do trabalho. São Paulo: LTr, 1985, p. 685 .

${ }_{537}$ Ibidem, p. 686/687.

${ }^{538}$ Ibidem, p. 687.
} 
Igualmente digno de menção é o projeto elaborado pelo Deputado Segadas Vianna. Nele, o direito de greve era reconhecido, desde que a manifestação se limitasse à paralisação do trabalho. $\mathrm{O}$ abandono coletivo do trabalho só seria permitido se tivesse por objeto alteração de decisão proferida em processo de dissídio coletivo, bem como de contrato coletivo de trabalho, ou de acordo de caráter coletivo homologado pela Justiça do Trabalho, quando já não estivessem em vigor as normas estabelecidas pela decisão, contrato ou acordo e houvesse transcorrido o prazo para sua revisão. Assim que surgisse motivo para declaração de greve, antes de qualquer movimento reivindicatório, os empregados deveriam dar ciência ao sindicato de cada grupo profissional interessado. Em no máximo cinco dias, o sindicato promoveria a realização de plebiscito, mediante voto secreto, devendo a decisão sobre a greve ser tomada por maioria. Se a deliberação fosse pela greve, eleger-se-iam, por escrutínio secreto, os delegados grevistas. O projeto estipulava ainda um pré-aviso de cinco dias, salvo nas atividades básicas, como, por exemplo, as relacionadas diretamente com o funcionamento de casas de saúde, hospitais, centrais geradoras de energia elétrica e manufatura de material de guerra. Nestas hipóteses o pré-aviso seria de dez dias. Quando a greve fosse motivada pelo não pagamento de salário, ou não cumprimento de decisão coletiva transitada em julgado, convenção coletiva em vigor ou acordo coletivo homologado ou não pela Justiça do Trabalho, o prazo do aviso prévio era reduzido para setenta e duas horas. O projeto vedava a contratação de novos empregados enquanto durasse a greve legal e assegurava ainda aos trabalhadores interessados o direito de aliciamento e propaganda da greve, permitindo aos grevistas a coleta de donativos para garantir o seu êxito. Seria facultado às partes, a qualquer tempo, entrar em acordo a fim de solicitar à Justiça do Trabalho a instauração de processo de dissídio coletivo. Nas atividades básicas, o representante do Ministério Público deveria, ex officio, solicitar a instauração de dissídio coletivo até cinco dias após ter ciência do litígio. Em qualquer caso a instauração do processo de dissídio coletivo não anularia o aviso prévio, nem interromperia a greve, salvo acordo entre as partes. A decisão proferida no dissídio coletivo teria, entre seus efeitos, o de por fim à greve ${ }^{539}$. Comentando referido projeto, Batalha destaca que "a intervenção da Justiça do Trabalho seria obrigatória apenas nas atividades básicas; nas demais, seria facultativa" ${ }^{540}$.

\footnotetext{
${ }^{539}$ BATALHA, Wilson de Souza Campos. Tratado de direito judiciário do trabalho. São Paulo: LTr, 1985, p. 687.

${ }^{540}$ Ibidem, p. 687/688.
} 
Campos Batalha destaca ainda a contribuição do II Congresso Brasileiro de Direito Social. Nele ficou registrada a inoportunidade das greves e lock-outs em regime no qual os dissídios coletivos podem ser dirimidos por órgãos jurisdicionais. Contudo, diante do reconhecimento do Direito de Greve na Convenção de Chapultepec, ficou consignado que os movimentos paredistas deveriam ser regulamentados à luz dos ensinamentos da legislação comparada e norteada pelos princípios do Código Social de Malines ${ }^{541}$.

Após a regulamentação do Direito de greve pela Lei 4.330/64, diversas normas foram editadas regulamentando os dissídios coletivos ${ }^{542}$. Segundo Batalha, o objetivo destas normas, conhecidas como política salarial do Governo, foi equacionar os pronunciamentos da Justiça do Trabalho em termos de conveniência, oportunidade e possibilidade dentro da conjuntura sócio-econômica ${ }^{543}$.

O texto do Projeto que culminou na Emenda Constitucional número 45 previu, durante a maior parte de seu longo trâmite pelo Congresso Nacional, a completa extirpação da prerrogativa de edição de normas pelo Poder Judiciário. Apenas no derradeiro momento do trâmite legislativo é que se alterou o projeto para possibilitar o ajuizamento do dissídio coletivo de comum acordo ${ }^{544}$. A idéia era acabar, efetivamente, com o Poder Normativo da Justiça do Trabalho.

Diante da resistência da bancada operária a aceitar essa hipótese, a redação do projeto foi alterada no último momento e o Poder Normativo mantido, porém com uma singela alteração. Paulo Eduardo Vieira de Oliveira, bem observa que a alteração sofrida pelo $\S 2^{\circ}$ do artigo 114 da CF implicou em "restrição nas hipóteses de atuação do Poder Judiciário, com o intuito de incentivar a autocomposição entre as categorias econômica e profissional". A intenção do legislador ao exigir o "comum acordo" das partes para ajuizamento do dissídio coletivo de natureza econômica teria sido, segundo aludido autor,

${ }^{541}$ BATALHA, Wilson de Souza Campos. Tratado de direito judiciário do trabalho. São Paulo: LTr, 1985, p. 688

${ }_{542}$ A Lei n. 4.725, de 13 de julho de 1965, de 13.7.1965, modificada pela Lei n. 4.903, de 16.12.1965 e regulamentada pelo Decreto n. 57.627, de 13.1.1966. Seguiram-se a ela os Decretos-leis n. 15, de 19.7.1966 e n. 17, de 22.8.1966. Posteriormente, dispuseram a respeito a Lei n. 5.451, de 12.6. 1968, bem como a Lei $\mathrm{n}$. 6.147, de 29.11.74 e a Lei n. 6.205, de 29.4.75.

${ }_{543}$ BATALHA, Wilson de Souza Campos. Op cit, p. 692.

${ }^{544}$ BOUCINHAS FILHO, Jorge Cavalcanti. A atual dimensão do debate sobre o ajuizamento do dissídio coletivo de comum acordo. A tese da inconstitucionalidade da exigência do impulso bilateral. Jus Navigandi, Teresina, ano 13, n. 1792, 28 maio 2008. Disponível em: <http://jus.com.br/revista/texto/11315〉. Acesso em: 28 dez. 2011. 
estimular as partes a procurar por mais tempo e com mais intensidade uma autocomposição e diminuir a demanda de ações no Judiciário Trabalhista ${ }^{545}$.

Similar à discussão travada durante o trâmite do Projeto que culminou na edição da Emenda Constitucional n. 45, foram os debates feitos no Fórum Nacional do Trabalho, ocorrido concomitantemente aos trâmites finais do Projeto de Emenda Constitucional, no ano de 2004. Nele, patrões e trabalhadores defenderam, inicialmente, a idéia de que o Poder Normativo deveria ser extinto, justificando que a intervenção da Justiça do Trabalho nas negociações coletivas impedia o amadurecimento da relação capital e trabalho. Somente após a intervenção do Juiz do Trabalho Luiz Philippe Vieira de Mello Filho, representante do TST, optou-se pela extinção parcial do poder normativo, ficando condicionado o seu exercício à solicitação conjunta das partes em conflito ${ }^{546}$.

Ao alterar a redação do artigo 114 da Constituição Federal para incluir o inciso II em que se afirma expressamente "competir à Justiça do Trabalho julgar as ações que envolvam exercício do direito de greve", o novo texto constitucional parecia não haver deixado margem para grandes discussões acerca da competência da justiça especializada para enfrentamento dessas questões. Diversos textos doutrinários foram redigindo sustentando a ampliação da competência da Justiça do Trabalho também para contemplar o julgamento das aludidas ações ${ }^{547}$.

Acreditava-se que com isso se corrigiria um antigo equívoco do organograma do Judiciário Brasileiro que era a atribuição de competência para a Justiça Comum julgar questões possessórias que apresentavam, como matéria de fundo, questões relativas a direitos coletivos do trabalho, matéria extremamente específica que não faz parte da esfera de conhecimento de todos os juslaboralistas, e com muito mais razão não faz parte do interesse dogmático daqueles que oficiam nos órgãos da Justiça Comum.

\footnotetext{
${ }^{545}$ OLIVEIRA, Paulo Eduardo Vieira de. Negociação coletiva. In: MAIOR, Jorge Luiz Souto e CORREIA, Marcus Orione Gonçalves. Curso de direito do trabalho, volume 3: direito coletivo do trabalho. São Paulo: LTr, 2008, p. 126.

546 FERREIRA, Mônica Brandão. O dissídio coletivo na Justiça do Trabalho: da necessidade do comum acordo para o seu ajuizamento. Revista LTr, volume 71, n 01, Janeiro de 2007, p. 33.

547 Segundo Luiz Alberto de Vargas e Ricardo Carvalho Fraga, "A Justiça do Trabalho passa a ter competência para todas as ações que envolvam o exercício de greve. Assim, deslocam-se para a Justiça Especializada as ações que hoje envolvem, por exemplo, ações possessórias que visem a manutenção ou restituição de posse sobre imóveis ocupados por grevistas (arts. 932 e 933 do CPC) ou interditos proibitórios que visem inibir a ação de piquetes grevistas (art. $3^{\circ}$ da Lei n. 7.783/89) (VARGAS, Luiz Alberto de; FRAGA, Ricardo Carvalho. Relações Coletivas e Sindicais - Nova Competência após a EC. 45. In: COUTINHO, Grijalbo Fernandes; FAVA, Marcos Neves. Justiça do Trabalho: Competência ampliada. São Paulo: LTr, 2005, p. 335.
} 
Esperava-se decisões mais acertadas, em que não se verificasse tanta sobreposição do interesse patrimonial dos empregadores sobre o interesse coletivo dos trabalhadores na melhoria de sua condição social. Como salienta Ericson Crivelli, "as justiças estaduais, encarregadas das matérias cíveis, desconhecem, tecnicamente, as matérias típicas que estão envolvidas nos conflitos trabalhistas", o que teria feito com que decisões fossem tomadas quase sempre distantes da realidade das relações materiais em conflito ${ }^{548}$.

De forma até surpreendente, o Superior Tribunal de Justiça manteve, mesmo após a aludida alteração na Carta Magna, o entendimento de que a Justiça comum seria competente para o julgamento dos interditos proibitórios suscitados nas hipóteses de atos decorrentes do exercício do dirieto de Greve. De forma bastante acertada o Supremo Tribunal Federal, ao apreciar o Recurso Extraordinário n. 579648 reconheceu a competência da Justiça Especializada para apreciar a matéria ${ }^{549}$. Posteriormente editou a Súmula Vinculante n. $23^{550}$.

Apesar do acerto sob o ponto de vista da ténica jurídico-processual, o resultado, sob o ponto de vista da proteção do trabalhador foi, entretanto, decepcionante, como demonstra a seguinte passagem do texto de Ericson Crivelli:

A chegada na Justiça do Trabalho à matéria e sua posterior definição como órgão jurisdicional competente, em consequência destas decisões adotadas por parte expressiva dos seus juízes, tem agravado a crise na qual mergulhou o exercício do direito fundamental de greve no Brasil após o

\footnotetext{
${ }^{548}$ CRIVELLI, Ericson. Direito internacional do trabalho contemporâneo. São Paulo: LTr, 2010, p. 1425.

549 EMENTA: CONSTITUCIONAL. COMPETÊNCIA JURISDICIONAL. JUSTIÇA DO TRABALHO X JUSTIÇA COMUM. AÇÃO DE INTERDITO PROIBITÓRIO. MOVIMENTO GREVISTA. ACESSO DE FUNCIONÁRIOS E CLIENTES À AGÊNCIA BANCÁRIA: "PIQUETE". ART. 114, INCISO II, DA CONSTITUIÇÃO DA REPÚBLICA. JURISPRUDÊNCIA DO SUPREMO TRIBUNAL FEDERAL. COMPETÊNCIA DA JUSTIÇA DO TRABALHO. 1. "A determinação da competência da Justiça do Trabalho não importa que dependa a solução da lide de questões de direito civil" (Conflito de Jurisdição n. 6.959), bastando que a questão submetida à apreciação judicial decorra da relação de emprego. 2. Ação de interdito proibitório cuja causa de pedir decorre de movimento grevista, ainda que de forma preventiva. 3. $\mathrm{O}$ exercício do direito de greve respeita a relação de emprego, pelo que a Emenda Constitucional n. 45/2003 incluiu, expressamente, na competência da Justiça do Trabalho conhecer e julgar as ações dele decorrentes (art. 114, inciso II, da Constituição da República). 4. Recurso extraordinário conhecido e provido para fixar a competência da Justiça do Trabalho. (RE 579648, Relator(a): Min. MENEZES DIREITO, Relator(a) p/ Acórdão: Min. CÁRMEN LÚCIA, Tribunal Pleno, julgado em 10/09/2008, REPERCUSSÃO GERAL MÉRITO DJe-043 DIVULG 05-03-2009 PUBLIC 06-03-2009 EMENT VOL-02351-08 PP-01534 RTJ VOL-00208-03 PP-01271)

${ }^{550}$ STF Súmula Vinculante no 23. Competência - Processo e Julgamento - Ação Possessória - Exercício do Direito de Greve - Trabalhadores da Iniciativa Privada. A Justiça do Trabalho é competente para processar e julgar ação possessória ajuizada em decorrência do exercício do direito de greve pelos trabalhadores da iniciativa privada.
} 
início do uso dos instrumentos de direito real para dirimir estes conflitos coletivos de trabalho.

As decisões levarão ainda, em decorrência, caso não haja uma mudança no uso crescente deste mecanismo, à inviabilização econômica dos sindicatos brasileiros que persistirem em utilizar a paralisação como instrumento de defesa dos seus interesses. Ou ainda, como parece ser o objetivo dos empregadores brasileiros, ao abandono da greve como instrumento jurídico de solução de conflitos ${ }^{551}$.

A Justiça do Trabalho manteve sua tradicional tendência de ampla intervenção nos movimentos coletivos de trabalhadores, perceptível a partir do relato histórico feito até aqui. Essa resistência histórica em afastar o judiciário das discussões que envolvem o direito coletivo do trabalho, é fruto do que se poderia chamar de cultura da judiciarização dos conflitos, em particular dos conflitos de trabalho ${ }^{552}$.

No Brasil há uma grande resistência em se admitir outras formas de solução de conflitos trabalhistas, que não aquela ditada pelo Poder Judiciário. Fundamentando essa afirmação cabe lembrar a ampla discussão doutrinária e jurisprudencial acerca da inconstitucionalidade da exigência de tentativa de conciliação perante as Comissões de Conciliação Prévia, encerrada com a decisão do STF entendendo que essa medida efetivamente viola o princípio da inafastabilidade da jurisdição ${ }^{553}$. Cabe ainda ressaltar a resistência do Poder Judiciário em aceitar a arbitragem em questões que envolvam relações individuais de trabalho ${ }^{554}$ e a pequena procura do Ministério Público do Trabalho para

${ }^{551}$ CRIVELLI, Ericson. Direito internacional do trabalho contemporâneo. São Paulo: LTr, 2010, p. 1425.

${ }^{552}$ Como salienta Augusto César Leire de Carvalho "É da tradição da sociedade brasileira confiar ao poder judiciário a solução de seus conflitos" CARVALHO, Augusto Cesar Leire de. Direito fundamental de greve e interdito proibitório. In: ARRUDA, Kária Magalhães; COSTA, Walmir Oliveira da (coordenadores). Direitos coletivos do trabalho na visão do TST: homenagem ao Ministro Rider Nogueira de Brito. São Paulo: LTr, 2011, p. 29.

${ }^{553}$ PROCESSO OBJETIVO - PETIÇÃO INICIAL. A petição inicial do processo objetivo deve ser explícita no tocante à causa de pedir. JURISDIÇÃO TRABALHISTA - FASE ADMINISTRATIVA. A Constituição Federal em vigor, ao contrário da pretérita, é exaustiva quanto às situações jurídicas passíveis de ensejar, antes do ingresso em juízo, o esgotamento da fase administrativa, alcançando, na jurisdição cível-trabalhista, apenas o dissídio coletivo.(ADI 2139 MC, Relator(a): Min. OCTAVIO GALLOTTI, Relator(a) p/ Acórdão: Min. MARCO AURÉLIO, Tribunal Pleno, julgado em 13/05/2009, DJe-200 DIVULG 22-10-2009 PUBLIC 23-10-2009 EMENT VOL-02379-01 PP-00039 RTJ VOL-00213- PP-00184)

${ }^{554}$ DO RECURSO DA RECLAMANTE. DO DANO MORAL.Não provada a ocorrência dos fatos alegados pela recorrente que atingissem sua honra subjetiva ou objetiva, de forma a lhe causar constrangimento e dor íntima intensa, é conseqüência lógica o indeferimento do pedido de indenização por danos morais. DO RECURSO DA RECLAMADA. ARBITRÁGEM. DIREITO INDIVIDUAL DO TRABALHO. INCOMPATIBILIDADE. "O art. 114 da Constituição Federal delimita a competência da Justiça do Trabalho e apenas quanto às questões coletivas autorizou a arbitrágem. Não houve espaço constitucional para a arbitrágem nas demandas individuais trabalhistas. Longe das origens do Estado Liberal, hoje as relações trabalhistas, reconhecidamente desequilibradas na ótica individual empregado-empregador são relações que não autorizam o compromisso arbitral, afastando a jurisdição estatal. Apenas sob a ótica coletiva, juridicamente igualitária, ficou autorizada a solução extrajudicial dos conflitos através da arbitrágem" (Juíza 
arbitragens em relações coletivas de trabalho em relação ao número de dissídios coletivos ajuizados. A partir dos exemplos citados é possível constatar que tanto há uma resistência dos jurisdicionados em aceitar solução outra que não aquela fornecida pelo Poder Judiciário, quanto há certa resistência dos magistrados em reconhecer validade a outras formas de solução que não aquela outorgada por ele mesmo.

Não cabe aqui questionar os prós e contras desta flagrante primazia da solução jurisdicional em matéria de relações individuais de trabalho. Esta discussão foge ao objeto deste estudo. Cabe, entretanto, considerar os inconvenientes causados pela primazia da solução judicial em matéria de relação coletiva de trabalho. É preciso reconhecer que por melhor que sejam os magistrados trabalhistas eles raramente terão pleno e real conhecimento das peculiaridades próprias de cada categoria. Quem efetivamente conhece os interesses e as necessidades das partes envolvidas em cada atividade econômica são os integrantes das categorias profissionais e patronais. A intervenção judiciária nesta discussão acaba quase sempre inibindo a ação direta dos atores sociais. Propugna-se aqui, por essa razão, uma ampla atuação, inclusive com concessão de tutelas preventivas, para assegurar a realização dos movimentos grevistas e uma cautelosa atuação, predominantemente repressiva e excepcionalmente preventiva, quando se tratar de ações que visem tutelar direitos outros em face do direito de greve.

\subsection{EXEMPLOS DE EXCESSIVA INTERVENÇÃO DO JUDICIÁRIO NAS MANIFESTAÇÕES GREVISTAS}

Bernard Teyssié, em sua análise sobre os precedentes da jurisprudência francesa relacionada com o exercício do direito de greve, destaca que ao apreciar pedidos de intervenção em manifestações grevistas “ le juge risque porter atteinte à l'exercice du droit de grève" 555 . É inegável, portanto, o cuidado que devem ter os magistrados ao se deparar

ELKE DORIS JUST). Recursos conhecidos, improvido o da reclamante e parcialmente provido o da reclamada. TRT 10 Região, $2^{\mathrm{a}}$ Turma. RO 00470-2004-001-10-00-7. Relator(a):Desembargador MÁRIO MACEDO FERNANDES CARON. Julgamento proferido em 26/10/2005 e publicado em 27/01/2006)

${ }^{555}$ TEYSSIÉ, Bernard. Grève dans le secteur privé. Jurisclasseur Travail Traité, fasc. 70-10, 15 avril 2010. No referido trabalho, o jurista faz referência ao seguinte precedente que, de forma bastante expressiva, nega a possibilidade de interferência do judiciário nos movimentos grevistas: "le juge de l'ordre judiciaire, qui n'a reçu ni de la loi, ni des parties, mission d'arbitrer ou de trancher un conflit collectif du travail n'a pas qualité ni compétence pour apprécier le bien-fondé et, par suíte, la legitimité des revendications d'ordre professionnel présentées par l'une ou l'autre des parties au conflit; ... il ne lui appartient pas de substituer sa propre appréciation de la rationalité du mouvement collectif à celle normalement débattue entre employer et 
com demandas cujo provimento possa resultar em intervenção estatal no direito de greve. Sobretudo em um país como o Brasil, cuja Constituição veda a interferência e a intervenção do estado na organização sindical. E a prerrogativa de deliberar sobre a oportunidade de realizar movimentos grevistas e sobre os interesses que por meio destes movimentos deve defender integra, inegavelmente, o conceito mais amplo de organização sindical, expressão que não deve ser lida apenas como definição dos órgãos que integram os entes sindicais.

Oscar Ermida Uriarte destaca, em obra oficial da Organização Internacional do Trabalho, o paradoxo funcional verificado no tratamento trabalhista do conflito, em geral, e da greve, em particular. $\mathrm{O}$ autor uruguaio ressalta que enquanto no plano teórico geral dos princípios e das grandes abstrações, sustenta-se a normalidade e - mais do que isso - a essencialidade do conflito nas relações de trabalho e no direito do trabalho, na análise dos casos concretos tende-se a limitar as hipóteses do conflito e a ampliar suas formas consideradas anômalas ${ }^{556}$.

Ele critica ainda a flagrante contradição entre o discurso acerca da principiologia do direito do trabalho, alicerçado na triangularidade composta pela autonomia sindical, autonomia coletiva e autotutela e o estado de perturbação em que fica a maioria dos operadores jurídicos e políticos toda vez que enfrenta um conflito real ou deve tomar uma decisão a respeito, concebendo-o, consciente ou inconscientemente, como uma anomalia $^{557}$. Bastante interessante é a reflexão de Jean Emmanuel Ray:

Si pour le juge français, sinon pour le juriste, la grève apparaît surtout à travers ses dysfonctions, les sociologues nous montrent les fonctions éminemment positives qu'elle peut également remplir: affirmation de la cohésion interne de chaque groupe, évaluation objective du rapport de force permettant une négociation réelle, mais aussi et surtout moyen d'expression avant de constituer un moyen de préssion sur l'employer ${ }^{558}$.

syndicat professionnel, non plus que d'exercer un controle sur les problèmes d'ordre technologique, économique ou financier qui font l'objet du débat et d'imposer sa solution auxdits problèmes" (CA Paris, 27 janv. 1988, deux arrêts: JCP G 1988, II, 20978; JCP E 1988, II, 15140, note B. Teyssié; Dr. Soc. 1988, p. 246, obs. J-E. Ray; D. 1988, jurispr.. p. 351, note J.-C. Javillier; Gaz. Pal. 1988, 1, 131, concl. Lupi. -Adde, TGI Evry, réf., 26 juill. 1990: RJS 1990, n. 915).

556 ORGANIZAÇÃ̃O INTERNACIONAL DO TRABALHO. A greve: o direito e a flexibilidade. Brasília: Organização Internacional do Trabalho, 2002, p. 82.

557 Ibidem.

${ }^{558}$ RAY, Jean-Emmanuel. Le juge et les conflits collectifs de travail. Droit Social, n. 7-8 - Juillet-Août 1986, p. 623 . 
Analisando as decisões proferidas pelo judiciário brasileiro, quando provocado a proferir tutela preventiva em face do direito de greve, é possível perceber o temor de excessos no movimento grevista.

Ao julgar o interdito proibitório tombado com o número 000106458.2010.5.05.0025, a 25 ${ }^{\mathrm{a}}$ Vara do Trabalho de Salvador, determinou a expedição de mandado proibitório ordenando que o réu se abstivesse de praticar todo e qualquer ato que viesse a molestar a posse mansa e pacífica do autor sobre os imóveis de sua propriedade, onde estão instalados os seus estabelecimentos, e providenciasse a imediata retirada de pessoas que pudessem vir a se postar nas portas de acesso delas, bem como de veículos, de cavaletes, de correntes, de cadeados, de faixas e de objetos que possam impedir, também, a entrada de clientes, aplicadores e usuários em geral, e, ainda, de aparelhos de som e/ou de instrumentos que possam provocar ruídos, perturbando a ordem e a paz no local e nas imediações, fixando pena pecuniária de $\mathrm{R} \$ 1.000,00$ por dia, para a hipótese de descumprimento desta ordem judicial. Autorizou ainda a utilização de força policial para garantir o efetivo cumprimento da ordem então expedida.

A decisão foi fundamentada na existência nos autos de documentos, em especial fotografias, que demonstravam que o Sindicato réu estava adotando a prática de lacrar a entrada dos estabelecimentos do autor com faixas e cartazes, impedindo o acesso não só aos trabalhadores que não queriam aderia ao movimento grevista, mas também a qualquer pessoa que pretendesse adentrar neles, o que feriria outra garantia fundamental: o direito de ir e vir, também previsto em sede constitucional (art. $\left.5^{\circ}, \mathrm{XV}\right)$.

Sem adentrar novamente na discussão acerca da real violação ao direito de ir e vir dos não grevistas e dos consumidores, questão já enfrentada, é preciso refletir se a preocupação do órgão judicial não acaba impedindo o conflito, que como visto é normal e essencial às relações de trabalho, constituindo-se ainda em um dos ônus de um modelo verdadeiramente democrático, de se instalar. Ao se pronunciar favoravelmente ao empregador antes mesmo do início das manifestações, o judiciário acaba interferindo no estusiasmo dos manifestantes e arrefecendo seus ânimos. 
Mas não é só. Acaba interferindo na forma escolhida pelos grevistas para fazer a sua manifestação. Estratégia que consiste em tentar burlar o enfraquecimento de seu poder de pressão provocado pelo advento da tecnologia, como já salientado.

O ideal, em um regime democrático, em que se considera o conflito essencial para a regulamentação das categorias, seria esperar o conflito eclodir e sancionar eventuais abusos de forma exemplar, para que no futuro não se repitam.

Outra interessante decisão estudada no decorrer das pesquisas foi a prolatada pela $1^{\text {a }}$ Vara do Trabalho de Criciúma, Santa Catarina, nos autos do interdito proibitório tombado com o número 02988-2008-003-12-00-0. Reconsiderando decisão anterior, aludido órgão deferiu a medida requerida para determinar a abstenção pelos grevistas da prática de atos que impedissem o livre acesso dos empregados que desejassem trabalhar durante o movimento grevista, bem como dos clientes aos estabelecimentos, inclusive na parte destinada aos caixas eletrônicos, ou qualquer outro ato que configura piquete e coloque em risco a segurança e a integridade física das pessoas e estabelecimentos bancários. Arbitrou multa de $\mathrm{R} \$ 5.000,00$ (cinco mil reais) por dia para eventual hipótese de descumprimento.

Visando tutelar os direitos de não grevistas e de clientes, o órgão em questão determinou a não realização de piquetes, contrariando o disposto no artigo $6^{\circ}$ da Lei $7783 / 89$ que assegura aos grevistas o emprego de meios pacíficos tendentes a persuadir ou aliciar os trabalhadores a aderirem à greve, entre os quais sempre se incluiram os piquetes pacíficos. Como salienta Paulo Garcia, os piquetes jamais poderão ser proibidos, por estarem integrados no direito de greve. Em sua visão, o picketin estaria para a greve assim como a liberdade de palavra e reunião está para os partidos políticos nos períodos eleitorais $^{559}$. Não se pode presumir que um piquete será violento. É preciso esperar a sua ocorrência para analisá-lo e sancionar eventual excesso.

Melhor seria que ao invés de deferir liminar em interdito proibitório para arbitrar multa por descumprimento da obrigação de fazer piquetes pacíficos, o julgador houvesse aguardado a manifestação e, em caso de excesso, sancionado o responsável pelo exercício abusivo do direito de greve. A tutela preventiva, como já salientado, interfere no poder de organização dos trabalhadores e, por essa razão, afronta o direito de greve.

${ }^{559}$ GARCIA, Paulo. Direito de Greve. Rio de Janeiro, Edições Trabalhistas, 1961, p. 159. 
A $2^{\mathrm{a}}$ Vara do Trabalho de Lages, Santa Catarina, por sua vez, concedeu, nos autos do interdito proibitório tombado com o número 02546-2008-029-12-00-7, liminar garantindo o livre acesso às agências de determinada instituição financeira sediada na cidade pelos seus clientes, usuários e empregados que não aderiram ou não pretendem aderir ao movimento grevista, ou seja, que desejem trabalhar, garantido ainda a posse mansa e pacífica dos imóveis onde situam-se suas agências e estabelecimentos, devendo o sindicato se abster de efetuar manifestações no interor das agências de qualquer objeto ou pessoa que perturbe a ordem do interior das agências. Autorizou a utilização de força policial caso necessária, aplicando pena de multa diária de $\mathrm{R} \$ 15.000,00$ (quinze mil reais) até o limite de $\mathrm{R} \$ 150.000,00$ (cento e cinquenta mil reais).

O aspecto relevante acerca desta decisão não está tanto no comando judicial, mas na fundamentação. Aduziu-se que a greve dos bancários estava sendo divulgada pela mídia e que os documentos juntados comprovavam que também foi deflagrada contra o autor da ação.

Ora, como salienta Ronaldo Lima dos Santos, "a simples ameaça de greve nada mais constitui do que o prenúncio do exercício de um direito, constitucionalmente consagrado, pelos trabalhadores, não significando, ab initio, ameaça à posse" ${ }^{\Perp 560}$. Não poderia ter sido deferido interdito pelo simples fato de se estar na iminência da deflagração de uma greve.

A $38^{\text {a }}$ Vara do Trabalho do Rio de Janeiro deferiu em parte a liminar requerida nos autos do interdito proibitório tombado com o número 1227-2009-038-01-00-6 para declarar o direito dos empregados dos autores de exercerem livremente o direito de greve, nos termos do art. $9^{\circ}$ da CF/88 e Lei n. 7783/89, garantindo a atuação de diretores e delegados sindicais credenciados pelos sindicatos de classe no sentido de obterem a adesão dos trabalhadores à greve, através do convencimento pacífico, bem como permitir manifestações à frente dos prédios dos bancos-autores, observando, entretanto, a decisão do interdito proibitório que impossibilita bloqueio nas entradas das agências e unidades administrativas, assegurando, assim, o livre acesso de clientes, funcionários, fornecedores ou qualquer cidadão e veículos; declarar e determinar que estão impedidos quaisquer atos

\footnotetext{
${ }^{560}$ SANTOS, Ronaldo Lima dos. Interditos proibitórios e direito fundamental de greve. Revista Síntese trabalhista e previdenciária, n. 261, março de 2011, p. 73.
} 
de força física contra pessoas e bens no movimento paredista, ainda que seja com o objetivo de impedir acesso de clientes, trabalhadores ou veículos; determinar que estão proibidos atos que tenham como objetivo coagir moral ou fisicamente trabalhadores a aderirem ao movimento paredista, registrando que lícito é o livre convencimento através de convites aos empregados ou emprego de faixas, cartazes, panfletagem desde que não cause danos materiais aos réus; determinar que o sindicato réu abstenha-se de promover qualquer ato que impeça o livre acesso de pessoas, clientes, trabalhadores ou veículos nas dependências do réu, observando os parâmetros da fundamentação; em contrapartida, determinar que os bancos réus abstenham-se de impedir o livre exercício do direito à greve, coagindo empregados ou ameaçando rompimento de contratos de emprego ou aplicações de sanções a seus empregados que aderirem ao movimento paredista, observando todos os termos desta decisão; determinar que os bancos réus abstenham-se de impedir o livre acesso aos estabelecimentos dos dirigentes sindicais (diretores e delegados sindicais credenciados pelos réus) para realizar distribuição de jornais ou informativos para divulgação de assembleias e reuniões sindicais. Determinou ainda que o sindicato réu se abstivesse de praticar qualquer ação ou omissão que restrinja o acesso de qualquer pessoa aos estabelecimentos da autora, bem como veículos, com proibição da afixação de cartazes no interior de suas dependências, ou qualquer outro ato que caracterize moléstia ou turbação à livre posse das empresas autoras de seus imóveis, onde suas agências ou sedes administrativas se encontram localizadas, sob pena de multa diária de $\mathrm{R} \$ 10.000,00$ (dez mil reais).

Não obstante demonstre grande preocupação em não restringir o direito de greve, a decisão mencionada não pode quedar isenta de censura. Primeiramente há que se reconhecer a desnecessidade de um provimento judicial para afirmar apenas e tão somente que a greve deve ser exercida dentro de seus limites. A estipulação de astreintes para o exercício da greve fora dos parâmetros legais consiste em inaceitável bis in idem na medida em que, interpretada literalmente e de forma diversa da aqui proposta, a Lei 7.783/89 estatui que a sanção pela realização de greve fora das hipóteses legais é o reconhecimento do exercício do direito de greve de forma abusiva. Em segundo lugar, é preciso reconhecer que a determinação judicial de que apenas dirigentes sindicais tenham acesso aos estabelecimentos para realizar distribuição de jornais ou informativos para divulgação de assembleias e reuniões sindicais viola frontalmente o direito de greve. Sendo o exercício da greve um direito individual de exercício coletivo e não um direito do 
sindicato, não se pode tolher o direito de todos os trabalhadores participarem das manifestações.

A Juíza Diretora do Fórum de Barueri, em razão da urgência, concedeu, nos autos do interdito proibitório tombado com o número 002799.2010.201.02.00.0, liminar para que o sindicato dos empregados em estabelecimentos bancários de São Paulo, Osasco e Região, suspendesse eventual prática de atos que pudessem embaraçar o exercício de direitos fundamentais de terceiro e de molestar a posse mansa e pacífica do autor sobre os imóveis localizados em Barueri, nos endereços relacionados na dita decisão, inclusive mantendo referidos imóveis e o acesso a eles, livre e desembaraçado de pessoas e coisas, garantindose o pleno exercício do direito de greve, desde que as manifestações, pessoas e coisas estejam a uma distância mínima de 50 (cinquenta metros). Pelo descumprimento total ou parcial da medida em questão, arbitrou a d. julgadora multa de $\mathrm{R} \$$ 5.000,00 (cinco mil reais) por dia até a efetiva observância do ora determinado.

A decisão registra manifesta violação ao direito de greve. Não obstante fale em garantia do pleno exercício do direito de greve, o comando flagrantemente o viola ao estabelecer a distância em que deverão ocorrer as manifestações do movimento paredista $^{561}$. Em um regime jurídico em que a constituição assegura aos trabalhadores o direito de decidir sobre a oportunidade para a realização da greve e os direitos que serão tutelados através do movimento, não lhes permitir definir a distância em que serão realizadas as manifestações consiste em um grande despropósito.

Não fosse isto o bastante o comando sentencial usa expressões imprecisas e vagas como "embaraçar o exercício de direitos fundamentais de terceiro" e "molestar a posse mansa e pacífica do autor" sobre determinados imóveis. A imprecisão dessas expressões gera insegurança capaz de desestabilizar o movimento paredista.

\footnotetext{
${ }^{561}$ Similar foi a decisão proferida no interdito proibitório tombado com o número 01485.2010.221.02.005. Destacando que a greve não é um direito absoluto, a julgadora concedeu liminar determinando expedição de mandado proibitório para que o requerido se abstivesse de I - praticar atos que pudessem embaraçar o exercício do direito de propriedade do requerente; II - impedir o trabalho; III - o ir e vir do público na agência; IV - molestar os bens que a guarnecem; V - impedir aos funcionários a livre entrada no estabelecimento; VI - bloquear os portões da agência; VII - formar piquete, desobedecendo a distância mínima de 5 metros do portal da agência; impedir ao público a entrada no estabelecimento. Fixou multa diária de $\mathrm{R}$ \$ 5.000,00 (cinco mil reais) por cada violação. Fundamentou sua decisão no fato de haver restado comprovado nos autos que o movimento em questão já havia sido deflagrado, com alguns incidentes em outros locais. Ainda que 5 metros não seja uma grande distância, não poderia o judiciário intervir determinando a distância em que deverão ser realizadas as manifestações grevistas. Deveria aguardar a manifestação acontecer para penalizar as inadequações.
} 
O Juízo da $1^{\text {a }}$ Vara do Trabalho de Rondonópolis, por sua vez, determinou a expedição de mandado proibitório a fim de que o Sindicato dos Empregados em Estabelecimentos Bancários de Rondonópolis e Região se abstivesse de impedir ou dificultar o acesso ao interior das agências da instituição financeira autora daqueles que pretendessem laborar ou dos clientes e usuários dos estabelecimentos bancários mencionados, bem como evitasse a realização de manifestações no interior das agências indicadas. Fixou multa de $\mathrm{R} \$ 10.000,00$ (dez mil reais) para eventuais descumprimentos e autorizou a requisição de força policial.

Primeiramente há uma questão formal a considerar. A decisão fala em evitar a realização de manifestações no interior das agências indicadas. Não se trata de um comando imperativo. Havendo manifestação estar-se-ia diante de um caso de descumprimento? Sujeitar-se-ia o réu a pena de multa? Trata-se de questão difícil de responder.

Em segundo lugar há que se considerar o próprio conteúdo da decisão. Estando a agência aberta ao público em geral, qualquer um pode entrar em suas dependências. Impedir apenas os grevistas de ingressar consiste em prática discriminatória e em conduta antissindical. Uma coisa é não permitir balbúrdia e excessos dentro da dependência da empresa. Outra é impedir os manifestantes de ingressar em espaço aberto ao público. Exercendo adequadamente o seu direito de greve eles poderiam perfeitamente ingressar nas dependências da agência e fazer manifestações empregando meios pacíficos tendentes a persuadir ou aliciar os trabalhadores a aderirem à greve e mesmo objetivando conquistar a simpatia dos usuários e clientes da agência. Esta proibição dá azo a discussões desnecessárias na hipótese, por exemplo, de um dos trabalhadores que fazia manifestações no espaço exterior da agência decidir lá ingressar para, por exemplo, ir ao banheiro. Se no caminho ele conversar com um colega tentando convencê-lo a aderir à paralisação poderia essa conduta ser considerada violação à decisão prolatada? A resposta é negativa, mas é preciso convir que essa situação hipotética poderia perfeitamente ser utilizada para tentar sancionar indevidamente o movimento dos trabalhadores.

A $2^{\text {a }}$ Vara do Trabalho de Vitória deferiu, nos autos do interdito proibitório tombado com o número 105200-45.2010.5.17.0002, a liminar requerida determinando que o sindicato réu se abstivesse de impedir o livre acesso de empregados, clientes e usuários 
às agências do banco autor, determinando ainda a retirada de pessoas, cavaletes, correntes, cadeados, faixas e objetos que impedissem a entrada nessas agências e a retirada de som e/ou outros instrumentos que pudessem provocar ruídos. Arbitrou multa de R \$ 10.000,00 (dez mil reais) para as hipóteses de descumprimento.

Também esta decisão retrata situação de excessiva intervenção do judiciário nos movimentos grevistas. A questão acerca da retirada de pessoas e objetos que impeçam o ingresso na agência é controversa. Não obstante se defenda neste trabalho que o bloqueio do ingresso em determinadas agências bancárias constitui exercício lícito do direito de greve, é forçoso reconhecer que, quanto a este ponto, o movimento grevista seria abusivo por violar o disposto no artigo $6^{\circ}, \S 3^{\circ}$ da Lei 7.783/89. Não se afigura razoável a determinação de retirada de som e outros documentos que pudessem provocar ruídos. Os discursos inflamados, as conclamações feitas para que os não grevistas adiram ao movimento também integram o exercício do direito de greve, não podendo, por conseguinte, ser coibidas.

Em uma situação extremada, em que o som esteja sendo utilizado em um volume tão elevado que impeça o trabalho, poder-se-á considerar uma determinação deste gênero. Mas, ela será repressiva, buscará sancionar um excesso já verificado. Nunca preventiva, para impedir que se utilize o som acima dos limites permitidos na legislação própria.

A Vara do Trabalho de Tubarão, por sua vez, concedeu liminar no interdito proibitório tombado com o número 01735-2008-041-12-00-6 para que o sindicato dos bancários da localidade se abstivesse de promover piquete de grevista na porta de duas agências bancárias, de promover o aliciamento com uso de força física ou violência psicológica em detrimento dos empregados que não aderiram ao movimento, de invadir as agências, de deslocar-se para o interior das agências para promover qualquer espécie de manifestação conexa ao movimento grevista; de impedir, por qualquer forma que fosse, o acesso de clientes ou não clientes às agências, fosse por constrangimento corporal, fosse por meio de objetos e empecilhos. Arbitrou multa de R \$1.500,00 (mil e quinhencos reais).

Além das já postas reflexões acerca da impossibilidade de se proibir piquete em frente às agências e de se impedir o deslocamento para o interior de agências abertas, de livre acesso ao público, para promover manifestações conexas ao movimento grevista a decisão em questão suscita uma terceira reflexão. O uso de força física ou violência 
psicológica em detrimento dos não grevistas é proibido por lei, o que torna desnecessário um provimento judicial com essa cominação. A decisão liminar acaba desta feita servindo apenas e tão somente para que o empregador a utilize como panfleto de propaganda contra o movimento grevista, divulgando-o entre os que não aderiram à greve e fazendo chegar aos manifestantes mais exaltados a informação de que a Justiça do Trabalho está contra eles.

A $2^{\mathrm{a}}$ Vara do Trabalho de Lages concedeu, ao julgar o interdito proibitório tombado com o número 02546-2008-029-12-00-7, liminar garantindo o livre acesso às agências de determinada instituição financeira na cidade catarinense pelos seus clientes, usuários e empregados que não aderiram ou não pretendessem aderir ao movimento grevista, garantindo ainda a posse mansa e pacífica dos imóveis das agências e estabelecimentos. Determinou ainda que o sindicato se abstivesse de efetuar manifestações no interior das agências de qualquer objeto. Autorizou a utilização de força policial e arbitrou multa diária variável de $\mathrm{R} \$ 15.000,00$ à $\mathrm{R} \$ 150.000,00$ (cento e cinquenta mil reais).

Além das críticas já dirigidas às decisões anteriormente transcritas no tocante à abstenção de manifestações no interior da agência, a decisão em comento merece censura por autorizar a utilização da força policial, que inibe, de forma indiscutível, o movimento paredista. Ainda que as autoridades se limitem a permanecer nas proximidades dos estabelecimentos da empresa, a simples presença de um contigente de policiais superior ao habitual intimida os manifestantes mais tímidos e enfraquece a ação coletiva.

Não fosse isto o bastante, a simples presença de policiais acaba por aumentar a rejeição do movimento pelos não envolvidos no conflito por atribuir ao movimento certo status de ilegalidade. Para a maior parte da população a presença da polícia é associada à prática de algum delito. E se já havia uma natural antipatia pelo movimento, fruto do efeito que a paralisação das atividades sempre causa na regular prestação de serviços à comunidade e/ou no preço do produto, essa tende a aumentar quando se passa a impressão de que há algo irregular na manifestação. 
É preciso ter em mente que a greve, como bem observa Jorge Luiz Souto Maior, "não pode ser tratada como um caso de polícia" ${ }^{562}$.

O Comitê de Liberdade Sindical da Organização Internacional do Trabalho entende que o recurso à polícia para romper uma greve constitui uma violação dos direitos sindicais ${ }^{563}$. Ele a admite, em caráter excepcional, e não a considera ofensiva ao direito de greve e, por conseguinte, à liberdade sindical, quando a situação produzida pelo movimento paredista apresenta gravidade e ameaça a ordem pública ${ }^{564}$ e tem, com este fundamento, denegado denúncias relacionadas com a intervenção de forças de segurança quando os fatos demonstram que a intervenção havia se limitado à manutenção da ordem pública, não significando uma limitação ao legítimo exercício do direito de greve ${ }^{565}$.

Uma leitura sistemática de todos os seus precedentes deixa claro que a intervenção policial deverá sempre ser o último dos recursos possíveis, somente admissível quando a situação apresentar gravidade ou se achar realmente ameaçada a ordem pública ${ }^{566}$, e sempre limitada a garantir a segurança ${ }^{567}$. A ameaça à ordem pública não pode,

${ }^{562}$ MAIOR, Jorge Luiz Souto. O direito de exercer o direito de greve. In: THOMÉ, Candy Florêncio e SCHWARZ, Rodrigo Garcia. Direito coletivo do trabalho: curso de revisão e atualização. Rio de Janeiro: Elsevier, 2010, p. 257.

${ }_{563}$ Precedente 643 da 5 a edição da Recopilación de decisiones y princípios del Comité de Libertad Sindical del Consejo de Administración de la OIT que assim dispõe: "El recurso a la policía para romper una huelga constituye una violación de los derechos sindicales". (Véase 304. ${ }^{\circ}$ informe, caso núm. 1863, párrafo 361.)

${ }^{564}$ Precedente 564 da $5^{\mathrm{a}}$ edição da Recopilación de decisiones y princípios del Comité de Libertad Sindical del Consejo de Administración de la OIT que assim dispõe: "Las autoridades sólo deberían recurrir a la fuerza pública cuando se produce un movimiento de huelga, si la situación entraña cierta gravedad o si se halla realmente amenazado el orden público".

${ }^{565}$ Precedente 642 da $5^{a}$ edição da Recopilación de decisiones y princípios del Comité de Libertad Sindical del Consejo de Administración de la OIT que assim dispõe: "El Comité resolvió desestimar denuncias relativas a la intervención de fuerzas de seguridad cuando los hechos demostraban que la intervención se había limitado al mantenimiento del orden público, no significando una limitación al legítimo ejercicio del derecho de huelga". (Véase Recopilación de 1996, párrafo 579.)

${ }^{566}$ Precedente 644 da $5^{a}$ edição da Recopilación de decisiones y princípios del Comité de Libertad Sindical del Consejo de Administración de la OIT que assim dispõe: "Las autoridades sólo deberían recurrir a la fuerza pública cuando se produce un movimiento de huelga, si la situación entraña cierta gravedad o si se halla realmente amenazado el orden público. (Véase Recopilación de 1996, párrafo 580 y, por ejemplo 299. ${ }^{\circ}$ informe, caso núm. 1687, párrafo 456; 302..$^{\circ}$ informe, caso núm. 1825 , párrafo 492; 304. ${ }^{\circ}$ informe, caso núm. 1863 , párrafo $361 ; 306 .^{\circ}$ informe, caso núm. 1884 , párrafo $695 ; 308 .{ }^{\circ}$ informe, caso núm. 1773, párrafo 446, caso núm. 1914, párrafo $669 ; 311$.er informe, caso núm. 1954, párrafo $407 ; 324 .^{\circ}$ informe, caso núm. 1865, párrafo $412 ; 332{ }^{\circ}$ informe, caso núm. 2252, párrafo 888 y 333.er informe, caso núm. 2153, párrafo 211.)

${ }_{567}$ Precedente 645 da 5 a edição da Recopilación de decisiones y princípios del Comité de Libertad Sindical del Consejo de Administración de la OIT que assim dispõe: "Si bien los trabajadores y sus organizaciones tienen la obligación de respetar la ley del país, la intervención de las fuerzas de seguridad en situaciones de huelga debe limitarse estrictamente al mantenimiento del orden público. (Véanse Recopilación de 1996, párrafo $581 ; 302 .^{\circ}$ informe, caso núm. 1849 , párrafo 211 y $324 .^{\circ}$ informe, caso núm. 2093, párrafo 437.). Assim também é o precedente 647, que dispõe que: "Cuando se produce un movimiento de huelga, las autoridades sólo deberían recurrir a la fuerza pública si se halla realmente amenazado el orden público. La intervención de la fuerza pública debe guardar relación con la amenaza al orden público que se trata de controlar, y los gobiernos deberían tomar disposiciones para que las autoridades competentes reciban 
naturalmente, ser confundida com a paralisação dos serviços ou com manifestações pacíficas, ainda que com ânimos exaltados, feitas pelos grevistas nas imediações dos estabelecimentos da empresa. Mesmo pequenos excessos praticados por alguns participantes do movimento, não podem justificar a intervenção da força policial.

Demais disso, a autorização para utilização de força policial não pode ser concedida de forma preventiva pelo judiciário para que os agentes públicos sejam deslocados para o local das manifestações, substituindo assim os agentes de segurança do empregador eventualmente disponíveis, mas com uma presença muito mais intimidadora. Eles devem ser convocados pelo empregador, diretamente e sem necessidade de ordem judicial, nas mesmas condições em que usualmente se convocaria quando a ameaça proviesse de outro tipo de manifestação. A presença policial nas imediações de manifestações grevistas deve, portanto, se limitar a situações extremadas em que a medida se mostre absolutamente indispensável.

Ericson Crivelli faz menção à decisões ainda mais surpreendentes proferidas pela Justiça do Trabalho. Menciona a concessão de liminares em interditos proibitórios para impedir realização de piquetes, manifestações, uso de cartazes, carros de som, com proibições de manifestações dos sindicatos a até distâncias mínimas de 100 e 200 metros. Fala ainda em cominação de multas pecuniárias que chegam a $\mathrm{R} \$ 90.000,00$ (noventa mil reais) por dia, por local de trabalho no qual se realizem piquetes e outras manifestações ${ }^{568}$.

Diante de decisões como a dos precedentes analisados e dos julgamentos referidos pelos autores mencionados, justifica-se a preocupação de Jorge Luiz Souto Maior de que sob o manto de defenderem sua propriedade e seu direito de liberdade e até o direito de ir e vir de seus clientes, os empregadores estejam se servindo de instrumentos processuais como o interdito proibitório para evitar que a greve seja efetivamente exercida e que não seja impedida a continuidade de sua atividade econômica ${ }^{569}$. Corroborando esta afirmação,

instrucciones adecuadas con el fin de eliminar el peligro que implican los excesos de violencia cuando se trata de controlar manifestaciones que pudieran entrañar alteración al orden público". (Véase Recopilación de 1996, párrafo $582 ; 320 .^{\circ}$ informe, caso núm. 1865 , párrafo $524 ; 324 .^{\circ}$ informe, caso núm. 2093, párrafo 437; $325^{\circ}$ informe, caso núm. 2068, párrafo $314 ; 33 .^{\circ}$ informe, caso núm. 2228 , párrafo $901 ; 336 .^{\circ}$ informe, caso núm. 2153, párrafo 175 y 338. informe, caso núm. 2364, párrafo 976.)

${ }^{568}$ CRIVELLI, Ericson. Interditos proibitórios versus liberdade sindical - uma visão panorâmica do direito brasileiro e uma abordagem do direito internacional do trabalho. Revista LTr. 73-12/1425.

${ }_{569}$ MAIOR, Jorge Luiz Souto. O direito de exercer o direito de greve. In: THOMÉ, Candy Florêncio e SCHWARZ, Rodrigo Garcia. Direito coletivo do trabalho: curso de revisão e atualização. Rio de Janeiro: Elsevier, 2010, p. 257. 
Ronaldo Lima dos Santos assevera, com toda razão, que constitui flagrante prática antissindical determinações judiciais destinadas a obstar a realização de assembleias na frente das empresas, panfletagem, utilização de carro de som, etc., atos tipicamente sindicais, que encontram pleno respaldo em nosso ordenamento constitucional ${ }^{570}$.

Como bem salientou Aloysio Corrêa da Veiga, “o interdito proibitório não é capaz de solucionar o conflito. Apenas garante a posse. Frustra muitas vezes todo o movimento com a concessão da medida liminar" ${ }^{571}$. A atuação preventiva do judiciário enfraquecendo o movimento grevista deve ser evitada, sob pena de a Justiça do Trabalho, que teria por papel institucional primar pela correta aplicação do Direito Laboral, acabar contribuindo para o esvaziamento de um dos seus institutos mais relevantes e fundamentais.

\subsection{INTERDITOS PROIBITÓRIOS}

O fato de as decisões analisadas no item anterior terem todas sido proferidas em sede de interdito proibitório ajuizado por empregadores apenas reflete a inadequada utilização que vem sendo dada a esse relevante instrumento de tutela possessória.

O interdito proibitório é disciplinado pela legislação brasileira em apenas dois artigos do Código de Processo Civil, o de número 932, que estabelece sua hipótese de cabimento, e o de número 933 que esclarece que em termos procedimentais ele seguirá o rito estabelecido para as ações de manutenção e reintegração de posse. O primeiro dos dispositivos mencionados estatui que o "O possuidor direto ou indireto, que tenha justo receio de ser molestado na posse, poderá impetrar ao juiz que o segure da turbação ou esbulho iminente, mediante mandado proibitório, em que se comine ao réu determinada pena pecuniária, caso transgrida o preceito".

Segundo Ericson Crivelli, acentuou-se, recentemente, a tendência de queda da eficácia na utilização dos dissídios coletivos como instrumento de enfrentamento das greves por parte dos empregadores brasileiros, o que teria, em alguma medida, contribuído

\footnotetext{
${ }^{570}$ SANTOS, Ronaldo Lima dos. Interditos proibitórios e direito fundamental de greve. Revista Síntese trabalhista e previdenciária, n. 261, março de 2011, p. 74.

${ }^{571}$ VEIGA, Aluysio Corrêa da Veiga. O Direito de greve e o interdito proibitório. In: BOUCINHAS FILHO, Jorge Cavalcanti; PEREIRA, José Luciano de Castilho; FAVA, Marcos Neves. $O$ direito material $e$ processual do trabalho dos Novos Tempos: estudos em homenagem ao Professor Estêvão Mallet. LTr, 2009, p. 36.
} 
para essa utilização em larga escala dos interditos proibitórios como política institucional de confronto com as greves ${ }^{572}$.

Analisando alguns dos interditos proibitórios que obtiveram o êxito total ou parcial para quem os ajuizou, é possível ressaltar ainda que além de proteção à posse mansa e pacífica do autor sobre os imóveis de sua propriedade, onde estão instalados os estabelecimentos, eles se fundamentam ainda na necessidade de se assegurar aos clientes o seu direito de ir e vir e aos trabalhadores não grevistas o seu direito ao trabalho.

Há que se refletir sobre a compatibilidade entre uma ação instituída para proteger a posse e uma justiça especializada destinada exclusivamente a cuidar de ações relacionadas com um direito obrigacional, o direito do trabalho. E mais especificamente, questionar a validade deste instituto para limitar um direito constitucionalmente garantido como é o caso do direito de greve.

\subsubsection{Competência material e hierárquica}

A discussão acerca da competência material da Justiça do Trabalho para julgar os interditos proibitórios encerrou-se com a edição da Súmula Vinculante n. 23 que dispõe que: “A Justiça do Trabalho é competente para processar e julgar ação possessória ajuizada em decorrência do exercício do direito de greve pelos trabalhadores da iniciativa privada”.

O verbete em questão, não conseguiu, contudo, por fim as infindáveis discussões processuais acerca da competência para julgamento das ações relacionadas com o direito de greve. O artigo 114, II da Constituição Federal, que atribui à Justiça do Trabalho competência para julgar as ações que envolvam o exercício do direito de greve, ainda não vem sendo adequadamente interpretado. Bom exemplo disso é a já referida discussão travada em torno da greve dos aeronautas e aeroviários em 2010. Para impedir que a paralisação em questão provocasse novo "caos aéreo" foram ajuizadas três ações coletivas, em três esferas judiciárias distintas. O Ministério Público do Trabalho pleiteou junto ao Tribunal Superior do Trabalho (TST) provimento liminar em ação cautelar preparatória de dissídio de greve que obrigasse $80 \%$ dos aeroviários e aeronautas a trabalharem normalmente do dia 22 de dezembro até o dia 3 de janeiro. A multa diária em caso de

\footnotetext{
572 CRIVELLI, Ericson. Interditos proibitórios versus liberdade sindical - uma visão panorâmica do direito brasileiro e uma abordagem do direito internacional do trabalho. Revista LTr. 73-12/1420.
} 
descumprimento seria de R $\$ 100$ mil. A Advocacia Geral da União, por sua vez, pediu ao Tribunal Regional do Trabalho que assegurasse, mediante decisão judicial, a continuidade das atividades de pelo menos $90 \%$ dos funcionários até o dia 7 de janeiro, sob pena de multa diária de R\$ 500 mil. Por fim, o Ministério Público Federal pleiteou a manutenção integral das atividades da categoria dos aeronautas e aeroviários sob pena de multa diária de R \$ 3 milhões de reais.

O juiz da $4^{\mathrm{a}}$ Vara Federal do Distrito Federal acolheu o pleito do Ministério Público Federal determinando que os sindicatos dos aeronautas (pilotos e comissários) e dos aeroviários (funcionários que trabalham em terra) garantissem que $100 \%$ dos trabalhadores mantivessem suas atividades, sob pena de multa diária de R $\$ 3$ milhões. Ao apreciar a ação cautelar preparatória de dissídio de greve ajuizada pelo Ministério Público do Trabalho, o Presidente do Tribunal Superior do Trabalho, ministro Milton de Moura França, concedeu liminar determinando que fossem mantidos em atividade $80 \%$ (oitenta por cento) do efetivo dos aeronautas e aeroviários, de forma a viabilizar o transporte aéreo em todo o território nacional, no período compreendido entre 23 de dezembro de 2010 e 2 de janeiro de 2011. E fixou multa diária de R $\$ 100$ mil, em caso de descumprimento da ordem.

Não é preciso muito para demonstrar os inconvenientes gerados por essa diversidade de soluções. As decisões diferem no valor da multa e no percentual de trabalhadores que deverão permanecer em atividade, o que provoca o surgimento de questionamentos como os seguintes: 1) há litispendência entre as decisões proferidas pela Justiça Federal e pela Justiça do Trabalho? 2) em caso afirmativo, qual das decisões deve ser cumprida, a que determina o cumprimento de todas as atividades das categorias ou a que determina o cumprimento de $80 \%$ das atividades? 3) é possível cumular as duas multas em caso de descumprimento das duas decisões? 4) é possível aplicar somente a maior multa caso a categoria assegure o cumprimento de mais de 80 e menos de $100 \%$ de suas atividades?

Sugere-se neste estudo uma interpretação do artigo 114, II da Constituição Federal que atribua à Justiça Especializada competência ampla para julgar as mais diversas ações em que se discuta o exercício do direito de greve. Caberia, desta feita, à Justiça do Trabalho, o julgamento de ações apresentadas por terceiro prejudicado por movimento paredista, exigindo reparação pelos prejuízos sofridos, ações propostas por empresas reclamando da conduta abusiva dos piqueteiros, litígios entre colegas trabalhadores 
denunciando agressões físicas ou morais mútas e ações de patrões exigindo indenizações por instalações, máquinas e equipamentos quebrados durante a greve. Razão assiste à Carla Romar quando afirma, portanto, que a competência da Justiça do Trabalho se estende para "qualquer lide envolvendo empresa e sindicato, empresas e grevistas, empresa e sindicalistas responsáveis pela greve, usuário que tenha sido prejudicado pela paralisação do serviço e o sindicato e/ou grevistas e/ou empresa"573. Atribuindo-se à Justiça do Trabalho competência para apreciar e julgar a demanda principal, há que se lhe reconhecer também competência para julgar as medidas cautelares e as tutelas inibitórias, como as que indevidamente foram ajuizadas na Justiça Federal para defesa dos usuários dos serviços aéreos.

Admitida essa hipótese elimina-se a possibilidade de simultaneidade entre as ações verificadas na Justiça do Trabalho e em outras esferas do judiciário. Permaneceria, contudo, o inconveniente de se verificar litispendência entre ações ajuizadas dentro da própria Justiça do Trabalho. Não são poucos os relatos de situações em que, após não obter êxito em pedido liminar em interdito proibitório postulado em primeira instância, o empregador ajuizou cautelar em dissídio coletivo e obteve no Tribunal, ou vice-versa.

Os inconvenientes provocados nesta última situação merecem especial destaque. Havendo o juízo monocrático vislumbrado ameaça à posse do empregador e concedido liminar restringindo a ação dos manifestantes, o movimento se enfraqueceu e terminou sem o resultado pretendido. Quando o Tribunal, em decisão cronologicamente posterior, enfrentou a questão considerando legítima a greve, já não havia nada a ser feito.

Esta dualidade de decisões sobre o mesmo fato só vem ocorrendo em razão do uso indevido do inerdito proibitório na Justiça do Trabalho. Como salienta Ronaldo Lima dos Santos, havendo procedimento específico para a solução das lides coletivas entre trabalhadores e empregadores, o dissídio coletivo, deverá ele ser utilizado, não havendo justificativa para se importar um instituto do processo civil. A singularidade de o Dissídio Coletivo, particularmente o de greve, que interessa ao presente estudo, ser julgado sempre por órgãos colegiado de segunda ou terceira instância, torna, a um só tempo, os juízos

573 ROMAR, Carla Teresa Martins. Nova competência da Justiça do Trabalho fixada pela Emenda Constitucional n. 45, de 2004 - análise dos incisos II, III e IV do art. 114 da Constituição Federal. In: MANUS, Pedro Paulo Teixeira; ROMAR, Carla Teresa Martins; GITELMAN, Suely Ester. Competência da justiça do trabalho e EC n. 45/2004. São Paulo: Atlas, 2006, p. 37/38. 
monocráticos incompetentes para apreciar demandas em que se discute o direito de greve e o interdito proibitório inadequado enquanto instrumento processual ${ }^{574}$.

\subsubsection{Legitimidade do sindicato para figurar no pólo passivo dos interditos proibitórios}

Outro argumento utilizado para afastar a aplicabilidade do interdito proibitório para a tutela da posse do empregador é o de que ele não poderia ser ajuizado em face do sindicato, por ser uma pessoa jurídica e pessoas jurídicas não poderiam praticar ato que caracterize moléstia a posse. Ronald Amorim e Souza destaca, a este respeito, que o sindicato não guarda para com os integrantes da categoria que representa se não uma relação meramente associativa e por deliberação do trabalhador, o que torna impossível a imposição, a qualquer integrante da categoria, que se ausente ou se apresente para o trabalho, em qualquer circunstância. Outrossim, em sendo os empregados grevistas os potenciais agentes da turbação ou ameaça de violência contra a posse, deveriam estes figurar no polo passivo das aludidas ações, inclusive para efeito de responsabilização cível $^{575}$.

A controvérsia acerca da possibilidade de o sindicato responder, em nome próprio, as ações relacionadas com o exercício da greve, particularmente com as questões possessórias que elas envolvem, vêm sendo enfrentada pela jurisprudência e doutrina francesas há algumas décadas. No caso conhecido como Ferodo, a Corte de Amiens determinou a expulsão dos delegados sindicais intimados, mas não dos outros ocupantes não notificados. Esta solução teria como fundamento o princípio do contraditório, elemento essencial dos direitos de defesa. Entendeu-se que o juiz não pode expulsar todos os ocupantes, mas apenas nominalmente referidos, por não ter como condenar uma pessoa que não foi chamada a se defender, não se deferiu o procedimento de référé, inoperante para fazer cessar a ocupação. Entendeu-se aplicável o artigo 5 do Código Civil Francês, que proíbe os juízes de pronunciar disposição geral e regulamentar nos casos que lhes são submetidos $^{576}$.

\footnotetext{
${ }^{574}$ SANTOS, Ronaldo Lima dos. Interditos proibitórios e direito fundamental de greve. Revista Síntese trabalhista e previdenciária, n. 261, março de 2011, p. 76.

${ }^{575}$ SOUZA, Ronald Amorim e. Greve e locaute. São Paulo: LTr, 2007, p. 182.

${ }^{576}$ Dans l'affaire Ferodo, la Cour d'Amiens avait ainsi ordonné l'expulsion des délégués syndicaux intimé, mais non des autres occupants non appelé en cause. Cette solution se fonde sur le principe du contradictoire,
} 
Referida decisão foi criticada em razão da dificuldade em indicar nominalmente todos os que ocupam o estabelecimento, que usualmente se recusam a relevar seu nome. Considerou-se que essa exigência teria tornado praticamente inócua a decisão prolatada. Uma ordem de expulsão pronunciada contra apenas alguns dos ocupantes pode servir de declaração acerca da ilicitude da ocupação, mas não fornece um título jurídico que englobe todos os autores do ato ilícito para com isso por um fim nele ${ }^{577}$.

Ora, sendo certo que os ocupantes do local de trabalho formam uma coletividade cuja composição pode ser incerta e flutuante, mas que é, em geral, relativamente organizada, obedecendo a palavras de ordem e aceitando uma disciplina, é a essa coletividade que deve ser dirigida a ação judicial e a ordem que nela vier a ser proferida. Trata-se de saber se ela deve ser expulsa, e não de fazer distinção entre seus membros conforme eles sejam ou não nominalmente $\operatorname{citados}^{578}$.

É por essa razão que uma parte da doutrina francesa sempre rejeitou os artifícios procedimentais invocados para limitar o alcance subjetivo da ordem de expulsão. Para essa parcela de juristas a solução passaria então pelo conceito de representação. Indicando os representantes de direito ou de fato dos grevistas, o empregador poderá obter uma decisão judicial oponível a toda a coletividade de grevistas ${ }^{579}$.

Ainda assim o empregador teria interesse em citar nominalmente o maior número de trabalhadores, assegurando-lhes o direito ao procedimento contraditório. De um lado porque se a via de fato que ele imputa aos grevistas não estiver caracterizada, ele corre o risco de fracassar caso os juges des référés adotem a tese de que a expulsão não pode ser ordenada sem ser precedida de um debate contraditório. Os presidentes de tribunais de

element essential des droits de la défénse: le juge ne peut condamner une personne qui n’a pas été appellee à se défendre. L'interdiction faite aux juge, par l'article $5 \mathrm{du}$ Code civil, $<<$ de prononcer par voi de disposition générale et réglementaire sur les causes qui leur sont soumises $>>$ n'avait au contraire rien à faire dans le debat, bien qu'elle ait été invoquée assez souvent, et en particulier dans l'affaire Ferodo. En ordonnant l'expulsion de grévistes même non appelés dans la cause, le juge des réferés ne posa pas en effet une règle suceptible de s'appliquer à d'autres litiges, et ayant une valeur générale. (SAVATIER, Jean. Expulsion et licenciement des grévistes occupant des locaux du travail. Droit social,n. 3, mars 1978, p. 122).

${ }^{577}$ La jurisprudence qui refuse ainsi d'ordonner l'expulsion de tous les occupants, mais seulement de ceux nommément assignes, aboutit à rendre la procédure de référé inoperante pour faire cesser l'occupation. Pratiquement, en effet, il est difficile à un huissier d'assigner nommément tous ceux qui occupent l'usine, alors qu'il ne refusent parfois de révéler leur nom. Une ordonnance d'expulsion prononcée contre certains seulement des occupants peu bien constater que l'occupation est illciti, mais non fournir un titre juridique enjoignant à tous les auteurs de l'acte illicite d'y metre fin. (Ibidem, p. 122).

${ }^{578}$ Ibidem, p. 122.

${ }^{579}$ Ibidem, p. 122/123. 
grande instância se mostrariam ainda mais inclinados a fazer jus a uma simples requisição do empregador. Por outro lado, obtendo a condenação de trabalhadores indicados nominalmente a evacuar os locais de trabalho, o empregador fica em condições de punir com pena de dispensa por falta grave (faute lourde) os trabalhadores que não executarem a ordem da justiça. Para Jean Savatier, a melhor solução para contornar a dificuldade procedimental criada pela exigência de indicação do nome dos grevistas que participam de um movimento de ocupação seria admitir que a citação dos representantes dos trabalhadores, no processo de référé, promovesse a expulsão de todos os trabalhadores que estivessem ocupando os estabelecimentos da empresa, mantendo-se a via da expulsão individual por requerimento aberta para os casos onde o procedimento de référé apresentasse dificuldades práticas sérias. A grande contribuição do caso Feredo seria justamente reconhecer que essas dificuldades podem entrar no caso em que o requerente esteja inclinado a obter a ordem de expulsão sem proceder a citação da parte contrária ${ }^{580}$.

No Brasil, como bem destaca Eduardo de Oliveira Cerdeira, tanto o TST quanto o STF reconhecem a possibilidade de tutela jurisdicional dos interesses individuais homogêneos pelos sindicatos como substitutos processuais. Naquele prevalece o entendimento de que, embora a substituição processual não seja ampla, é admissível a atuação dos sindicatos, como substitutos processuais, para a tutela jurisdicional dos interesses individuais homogêneos. Neste prevalece o entendimento de que a substituição processual é ampla, cabível não só para a tutela de interesses individuais homogêneos, mas também para a tutela de interesses individuais, inclusive na fase de execução ${ }^{581}$.

Sendo certo que o sindicato é legitimado para figurar no pólo ativo da ação coletiva, não há como não se lhe reconhecer legitimidade para figurar no pólo passivo da demanda. Diogo Campos Medina Maia, em obra bastante inovadora, chamou esta ação em que a coletividade figura no pólo passivo da relação jurídica processual, substituída por um legitimado extraordinário, na defesa de direitos individuais ou coletivos, homogeneamente lesionados, de ação coletiva passiva. O traço distintivo entre esta e a chamada ação coletiva ativa não estaria, em sua opinião, na natureza dos direitos que se pretende defender, mas na forma como os direitos são ameaçados ou lesionados ${ }^{582}$.

\footnotetext{
${ }^{580}$ SAVATIER, Jean. Expulsion et licenciement des grévistes occupant des locaux du travail. Droit Social, n. 3, mars 1978, p. 124.

${ }^{581}$ CERDEIRA, Eduardo de Oliveira. Ações coletivas e a substituição processual pelos sindicatos. São Paulo: LTr, 2010, p. 173.

${ }_{582}$ MAIA, Diogo Campos Medina. Ação coletiva passiva.Rio de Janeiro: Editora Lumen Juris, 2009, p. 159.
} 
Referido doutrinador sustenta que no que concerne ao posicionamento dos sindicatos, quando inseridos no processo coletivo, o regime de coisa julgada deve obedecer ao exigível para tal sorte de ações, isto é, a inversão do regime do artigo 103 do Código de Defesa do Consumidor, contando, no entanto, com uma pequena exceção: a formação da coisa julgada referente aos direitos individuais que são considerados disponíveis coletivamente na seara trabalhista deve se formar pro et contra. Quando, entretanto, o sindicato estiver inserido no processo coletivo especial, como nos casos de dissídios coletivos e ações de cumprimento, por disposição legal, a coisa julgada se forma erga omnes, independente da qualidade da prova produzida ou do resultado do processo, vinculando todos os trabalhadores substituídos, podendo, inclusive, serem elastecidos os efeitos da decisão também aos membros da categoria profissional compreendida na jurisdição do Tribunal (arts. 868 a 872 da CLT) ${ }^{583}$.

Há que se reconher, portanto, que assim como tem legitimidade para figurar no pólo passivo do dissídio coletivo de greve, defendendo a legitimidade do movimento paredista organizado por uma coletividade de trabalhadores, o sindicato apresenta legitimidade para figurar no pólo passivo dos interditos proibitórios defendendo a inexistência de ofensa à posse mansa e tranquila do empregador. Com razão Ronaldo Lima dos Santos ao afirmar "reconheceram-se como legitimados o empregador, de um lado, autor da ação de interdito, e o sindicato profissional do outro, tido como responsável direto pelos atos e condutas praticados pelos membros da categoria em determinado movimento paredista" $\quad{ }^{584}$.

\subsubsection{Movimentos paredistas e violação e ameaça à posse do empregador}

A reflexão passa ainda pelo reconhecimento de que os movimentos paredistas não causam moléstia à posse dos empregadores na acepção que levou à edição da referida norma. O objetivo da greve não é obter para si a posse direta ou indireta de determinado imóvel, mas tão somente pressionar o seu proprietário a atender determinadas reivindicações de certa categoria profissional. Neste sentido mostram-se dignas de transcrição as reflexões de Jorge Luiz Souto Maior:

\footnotetext{
${ }^{583}$ Idem, p. 165;

${ }^{584}$ SANTOS, Ronaldo Lima dos. Interditos proibitórios e direito fundamental de greve. Revista Síntese trabalhista e previdenciária, n. 261, março/2011, p.63.
} 
O "interdito proibitório", no entanto, é plenamente impróprio para a defesa dos interesses em questão, vez que vinculado às ações possessórias, onde esbulhos ou turbações obstruem o direito de propriedade. Os conflitos trabalhistas não se inserem no contexto de conflitos de terra, de invasões ou coisas do gênero. Os trabalhadores possuem relações jurídicas com as empresas e sua presença no ambiente de trabalho, para a execução de serviços ou para reivindicar direitos, faz parte da própria existência da empresa. Não há empresa sem trabalhadores.

Não se pode considerar, portanto, os trabalhadores como invasores. Sua manifestação em movimento paredista é ato democrático, para fins de estabelecer o necessário diálogo entre o capital e o trabalho. Faz parte do contexto da relação produtiva. Não se insere, pois, na esfera do esbulho ou turbação da propriedade alheia ${ }^{585}$.

Analisando os interditos proibitórios ajuizados, por exemplo, pelas instituições financeiras durante as greves organizadas pelos bancários, percebe-se claramente que a preocupação dos autores não é com a perda da posse direta ou indireta para o sindicato manifestante, mas com eventuais danos que venham a ser causados pelos grevistas ao seu patrimônio, assim como com atos que impeçam os trabalhadores não grevistas e os clientes de ter acesso aos estabelecimentos das empresas. Será que estas situações caracterizam-se, efetivamente, como moléstia à posse?

Ora, o interdito proibitório consiste, como bem observa Ronaldo Lima dos Santos, em típica ação possessória, de caráter mandamental, cujo objeto é a consecução da posse direta ou indireta do autor. O seu escopo seria obter a consecução de uma ordem judicial (liminar) instando alguém a se abster de praticar atos atentatórios da posse de outrem, sob pena de multa diária ${ }^{586}$.

Duas conclusões transparecem com muita clareza deste preceito legal: 1) o procedimento especial nele disciplinado destina-se a tutelar a posse, porquanto o legitimado para propor a referida ação é apenas o possuidor direito ou indireto; 2) trata-se de uma medida preventiva que não implica em imposição imediata de pena ao réu, mas em cominação de astreintes para inibi-lo de praticar ato considerado ilícito.

${ }^{585}$ MAIOR, Jorge Luiz Souto. O direito de exercer o direito de greve. In: THOMÉ, Candy Florêncio e SCHWARZ, Rodrigo Garcia. Direito coletivo do trabalho: curso de revisão e atualização. Rio de Janeiro: Elsevier, 2010, p. 257.

${ }_{586}$ SANTOS, Ronaldo Lima dos. Interditos proibitórios e direito fundamental de greve. Revista Síntese trabalhista e previdenciária, n. 261, março/2011, p.63. 
O objeto do interdito proibito é proteger a posse (direta ou indireta), injustamente ameaçada por ato de turbação ou esbulho. Como observa Ronaldo Lima dos Santos, “Tanto a turbação quanto o esbulho pressupõem para a sua caracterização que o ato praticado se mostre injusto, ilícito, ilegal ou abusivo, sem qualquer apoio em lei" ${ }^{587}$. A ilicitude do ato é, portanto, condição para a concessão do interdito. E as manifestações paredistas não constistuem ilícito.

A outra condição para a concessão do interdito seria o animus possidendi da parte contrária, exteriorizado na intenção do agente de praticar atos visando à obtenção da posse do autor. Também este requisito não pode ser identificado nos movimentos grevistas. Os manifestantes não desejam, isto é certo, despojar o empregador da posse da empresa. Muito pelo contrário, o seu desejo é retornar o mais rapidamente possível à situação verificada antes da eclosão do movimento, desde que, naturalmente, suas reivindicações sejam atendidas.

Santos destaca que a ação de interdito constitui um instrumento processual para a tutela da posse (direta ou indireta) enquanto elemento de exteriorização do domínio, de forma que essa tutela possessória desvela-se, em última análise, na proteção do próprio direito de propriedade ${ }^{588}$. E esse direito, como se pode concluir a partir da reflexão feita acima, não se encontra ameaçado, vez que o interdito não tem a finalidade de expropriar o bem do empregador ${ }^{589}$.

Após ponderar que o objetivo da greve é embaraçar a atividade empresarial com vistas a forçar uma negociação coletiva entre as partes, Ronaldo Lima dos Santos verifica, com razão, uma determinada atecnia na concessão de interditos proibitórios em hipóteses de exercício do direito de greve pela Justiça do Trabalho, na medida em que são indevidamente requeridos e concedidos interditos para a tutela da atividade empresarial e não de determinada posse em si. Conclui censurando o abuso de concessão de liminares

\footnotetext{
587 SANTOS, Ronaldo Lima dos. Interditos proibitórios e direito fundamental de greve. Revista Síntese trabalhista e previdenciária, n. 261, março/2011, p.63.

${ }^{588}$ Ibidem, p. 66.

589 VEIGA, Aluysio Corrêa da Veiga. O Direito de greve e o interdito proibitório. In: BOUCINHAS FILHO, Jorge Cavalcanti; PEREIRA, José Luciano de Castilho; FAVA, Marcos Neves. $O$ direito material e processual do trabalho dos Novos Tempos: estudos em homenagem ao Professor Estêvão Mallet. LTr, 2009, p. 35 .
} 
em decorrência da equivocada equiparação entre direito à continuidade da atividade empresarial e direito de posse seus desdobramentos ${ }^{590}$.

Eriscon Crivelli, por sua vez, critica a utilização de instrumento de tutela possessória e, portanto, real, para disciplinar questões nascidas em uma relação obrigacional afirmando que ao acolher o pedido da concessão da garantia judicial da posse, no caso das greves, o juiz está considerando em síntese, o trabalho humano como extensão da coisa cuja posse se pretende proteger.

\subsubsection{Dificuldades na caracterização do justo receio de dano à posse e na verificação de provas aptas à concessão do interdito}

Em se admitindo a validade do interdito proibitório para o fim a que se propõe, o que se admite para aprofundar a reflexão, há que se questionar o que deve ser considerado justo receio de ser molestado na posse. Novamente a natureza conflitiva da greve torna difícil chegar a uma conclusão.

Certamente não remanescem dúvidas de que um fazendeiro que percebe um agrupamento de dezenas de integrantes do Movimento dos Sem Terra (MST) em frente à sua fazenda entonando gritos de guerra armados com foices tem justo receio de ser molestado na sua posse. Mas, será o que o simples fato de haver aglomeração de grevistas em frente ao estabelecimento em que ordinariamente prestam serviços, protestando com fisionomia de pouco amistosa permite a mesma conclusão? A resposta precisa ser negativa. Se a aglomeração dos sem terra em frente à fazenda pode ser considerada um fato extraordinário que caracteriza o justo receio e justifica a concessão da tutela possessória, o mesmo não pode ser dito em relação à aglomeração de trabalhadores, comportamento ordinário em se tratando de exercício do direito de greve.

É um grande equívoco, portanto, concluir que o simples preaviso da greve justifica a tutela possessória. Nem mesmo a aglomeração de trabalhadores protestando justifica a medida em questão. O que poderia, então ser utilizado como prova em um interdito proibitório? $\mathrm{Na}$ maioria dos interditos proibitórios de que se tem notícia, as provas documentais juntadas consistem normalmente de recortes de jornais impressos, notícias

590 SANTOS, Ronaldo Lima dos. Interditos proibitórios e direito fundamental de greve. Revista Síntese trabalhista e previdenciária, n. 261, março/2011, p. 67/68. 
extraídas da rede mundial de computadores e fotos. Filmagens e diligência feita por serventuários de tabelionatos para constatar in loco as irregularidades aludidas ${ }^{591} \mathrm{e}$ depoimentos registrados em cartório também são usados para este fim.

Poucos são os escritos sobre o tema. Veruska Rodrigues Cardoso, Juliana Marrafon Linário Leal e Gilmara Pesquero Fernandes Mohr Funes asseveram que o "justo receio de moléstia da posse deve ser fundado em fatos concretos e não em simples temor de ordem subjetiva", devendo esta regra ser analisada casuisticamente, conforme os acontecimentos do caso concreto ${ }^{592}$. Referidas autoras questionam a coerência de manter a aplicação do interdito proibitório como instrumento de defesa da posse diante da exigência de preaviso porquanto os empresários devem, segundo exigência legal, ser avisados com no mínimo 48 horas de antecedência sobre possível paralisação. Em sua opinião, esta providência de legalização do movimento grevista, possibilita ao empresário/empregador utilizar o referido instrumento possessório e acaba cerceando o exercício do direito à greve porquanto este tempo é suficiente para impetrar o interdito proibitório e, sendo este concedido, o direito de realizar a greve ficará frustrado, e por fim, não surtirá o efeito almejado pela mesma ${ }^{593}$.

No mesmo sentido se posiciona Ronald Amorim e Souza, segundo quem o papel do sindicato, por imperativo legal, é aquele estabelecido no art. $4^{\circ}, \S 1^{\circ}$, da Lei de Greve. Logo, pela exação no seu cumprimento não cabe responder a demanda em juízo. Não constitui coação ou representa risco para o titular de direito a ameaça, por outrem, de exercício regular dos seus, ou cumprimento do dever legal ${ }^{594}$.

\footnotetext{
${ }^{591}$ O Ministro João Oreste Dalazen, enquanto Corregedor Geral da Justiça do Trabalho, deferiu liminar requerida nos autos da reclamação correicional formulada pelo Banco Bradesco em face de decisões proferidas pela MM. Juíza Fátima Ledra Machado, do TRT da $9^{a}$ Região, em sede de Mandado de Segurança (processo tombado com o número TST 200643/2008-000-00-00.2), baseando-se em atas de serverntuários de Tabelionato de notas que se dirigiram a determinada agência bancária e constataram, in loco, as irregularidades aludidas em certo interdito proibitório, como denota a transcrição a seguir: "No caso vertente, exsurge nítido o justificado receio de dano de difícil reparação ao ora requerente e, em particular, aos usuários dos serviços bancários, conforme transparece cristalinamente da documentação carreada aos autos da presente reclamação correicional. É o que se depreende do teor das Atas Notariais de fls. 71/74, em que se demonstra a existência de piquetes obstativos a impedir o livre acesso de empregados e clientes do ora Requerente às dependências de agências bancárias em Curitiba (PR). Trata-se de fatos devidamente constatados por serventuários de Tabelionato de Notas que, para tanto, pessoalmente dirigiram-se a agências bancárias do Banco Bradesco S.A., na capital paranaense".

${ }_{592}$ CARDOSO, Veruska Rodrigues. O interdito proibitório como meio de cerceamento do direito à greve. Disponível em <http://intertemas.unitoledo.br/revista/index.php/ETIC/article/viewFile/2588/2277>, acesso em 03 de janeiro de 2011.

${ }^{593}$ Ibidem, p. 8.

${ }^{594}$ SOUZA, Ronald Amorim e. Greve e locaute. São Paulo: LTr, 2007, p. 182.
} 
Ora, só pode ser considerado justo o receio que não se reduz em simples suspeita, em simples temor subjetivo. É preciso alguma fundamentação dele. O simples preaviso da greve não pode ser interpretado como moléstia ao direito de posse. Afinal se a greve, quando efetivamente iniciada, não representa violação ao direito de posse ou de propriedade do empregador, não há como se considerar o seu aviso uma ameaça. Não é concebível que a observância de uma formalidade estipulada em lei para o exercício de um direito possa ser interpretada como ameaça apta a justificar um mecanismo de tutela preventiva. É possível, contudo, que durante o prazo exigido pela legislação, cuja validade e compatibilidade com os princípios de liberdade sindical foi reconhecida pelo Comitê de Peritos da OIT, os trabalhadores manifestem-se de forma a justificar o justo receio de moléstia na posse. Em suma, a exigência de preaviso não basta, por si só, para caracterizar o justo receio de moléstia que a justifica.

Não obstante Sérgio Cruz Arenhart afirme que "Em se tratando de ação que visa impedir o prossegimento ou a repetição da ofensa, esta prova não guarda qualquer entrave. A ameaça no mais das vezes, apresentar-se-á como óbvia, pela simples ocorrência pretérita ou atual da violação do direito" ${ }^{, 595}$. Este entendimento parte da temerosa premissa de que alguém que agiu mal no passado sempre repetirá o erro no futuro, incompatível, por exemplo, com as idéias de ressocialização que permeiam o direito punitivo moderno. Em segundo lugar há que se reconhecer que ele criaria uma espécie de sanção perpétua para os ilícitos cometidos no passado na medida em que elas sempre justificariam ações preventivas fundadas em erros pretéritos.

Esta lógica pode servir para determinado tipo de tutela preventiva, relacionado com prevenção de um dano a honra em face de um personagem humorístico ou coisa do gênero. Alguém que se sentiu ofendido com determinada imitação caricaturada feita em uma apresentação tem o direito de, além de pleitear a reparação pelo dano moral, tentar impedir que ela se repita na apresentação seguinte. Não se adequa, entretanto, para comprovar justo receio de ameaça à posse do empregador em face de um movimento grevista.

Ao contrário do que se verifica no mencionado caso de lesão à honra, em que diversas circunstâncias podem fazer presumir que o espetáculo repetirá as brincadeiras ou realizará outras similares, a greve é sempre desencadeada após frustrações em negociações

${ }^{595}$ ARENHART, Sérgio Cruz. A tutela inibitória da vida privada. RT: 2000, p. 142. 
absolutamente independentes e desvinculadas das anteriores. As reivindicações são outras e, por vezes, há alteração até mesmo no nome dos integrantes do comando sindical.

Após reconhecer que "ninguém jamais conceberia a condenação de um réu tendo tão somente por base sua conduta pretérita, por ser ele um contumaz devedor", Sérgio Cruz Arenhart propõe entendimento diverso para ações que não sejam condenatórias, mas sim inibitórias de dano futuro. Em sua opinião, argumentos baseados em conduta pretérita seriam cabíveis na avaliação de pedidos de tutela urgente, "até mesmo para encontrar-se a ameaça concreta e objetiva (rectius, a plausibilidade de sua ocorrência) necessária à tutela preventiva de urgência" 596 .

E vai além. Em sua opinião, esta "redução do módulo da prova poderia ter aplicação mesmo em relação ao provimento final da ação inibitória, dado que a demonstração segura da ameaça de lesão ao direito é, em muitos casos - e mesmo frente à possibilidade de amplo espaço probatório no processo - impossível". Afinal, neste tipo de ação "O que se pode é demonstrar ao juiz que possivelmente havia a ameaça (prova possível) de lesão ao direito; pode-se trazer dados objetivos que demonstrem essa possibilidade, mas jamais será possível ter-se que estes dados objetivos realmente indicam a ameaça concreta" ${ }^{597}$. Conclui ponderando ser possível que, mesmo diante desses dados objetivos ou do recurso ao Judiciário, o réu desista de impor a lesão ao direito do requerente, hipótese em que a ameaça de lesão jamais se consumaria e asseverando que os elementos indiciários apresentados seriam bastante para a cognição exauriente do juiz. Para ele, "exigir mais do que isto significaria obrigar a limites que transpassem a possibilidade humana, o que corresponderia a determinar o sacrifício do direito que se busca tutelar" ${ }^{598}$.

O douto processualista conclui ponderando que "entre a negação de justiça e a redução da exigência de prova (por impossibilidade de capacidade de provar), evidente que o Direito e a Justiça se põem ao lado desta última, já que, concretamente, é a única solução factível" 599 .

Esta conclusão tampouco se coaduna com o direito de greve. Como salientado no tópico em que se tratou do balizamento para solucionar colisões entre o direito de greve e

\footnotetext{
${ }^{596}$ ARENHART, Sérgio Cruz. A tutela inibitória da vida privada. RT: 2000, p. 150.

${ }^{597}$ Ibidem.

${ }^{598}$ Ibidem.

${ }^{599}$ ARENHART, Sérgio Cruz. A tutela inibitória da vida privada. RT: 2000, p. 150.
} 
outros direitos fundamentais, só é admissível modelo ilustrativo para análise acerca de eventual conflito entre outro direito fundamental e o direito de greve se ele partir da presunção de legitimidade e legalidade do movimento paredista.

Esta mesma explicação acaba com outra possível justificativa para admissão dos interditos proibitório que seria a de que o provimento judicial neste caso não passa de uma predeterminação do valor da sanção pecuniária a ser aplicada em caso de descumprimento do comando. Logo, se nenhuma irregularidade houver, sanção alguma será aplicada.

O grande impasse, em se tratando de discussão acerca do direito de greve, é o efeito devastador que a notícia da liminar tem na coalização de trabalhadores, ainda que a sanção pecuniária nunca seja aplicada. É natural que o valor da multa, quando muito elevado, acabe assustando alguns manifestantes menos corajosos, fazendo-os desistir da manifestação. O que é relevante ressaltar é que, independentemente desse valor, ou ainda que nenhum valor fosse arbitrado, a divulgação da notícia de que um juiz deu razão ao empregador tem um efeito devastador no movimento de trabalhadores. Essa informação, se bem explorada convencerá os indecisos a não aderir ao movimento e, eventualmente, convencerá alguns mais exaltados a abandoná-lo.

Questão bastante interessante, e digna de especial registro, é a referente à validade das fotos como prova da tese que fundamenta o interdito ajuizado pelo empregador e a defesa apresentada pelo réu. Por se tratar de imputação de um fato danoso, poder-se-ia pensar que uma única foto demonstrando prática de ato abusivo, ainda que isolado e não compactuado pelo "comando" do movimento seria suficiente para justificar a tutela inibitória buscada e nem mesmo um álbum de fotos registrando momentos em que a greve foi exercida de forma pacífica seria capaz de ilidir esta conclusão.

Alegar-se-ia neste caso que o fato de se juntar fotos de determinado movimento paredista no momento em que as manifestações eram pacíficas não pode implicar na conclusão de que nunca ocorreram excessos. É muito fácil concentrar os registros fotográficos no momento em que a greve transcorreu em sua normalidade para somente depois iniciar os abusos. Igualmente fácil é selecionar apenas as fotos que sugerem a licitude no movimento, deixando de lado as mais comprometedoras. 
É compreensível porque em processos judiciais uma foto retirada no momento em que o ilícito é praticado mostra-se suficiente para comprovar a irregularidade enquanto centenas ou até mesmo milhares de fotos em momentos lícitos não afastam essa conclusão. Uma foto retratando um ilícito afasta a conclusão de que não houve irregularidade, mas nem mesmo mil fotos de comportamentos adequados são capazes de comprovar que nunca houve abuso.

Esta solução, contudo, não se afigura a mais adequada em se tratando de discussão acerca do direito de greve. Isto porque, como já salientado, o direito de greve é um direito individual de exercício coletivo. Sob esta perspectiva, advoga-se aqui a tese de que o abuso de um único manifestante ou de alguns poucos manifestantes mais exaltados, desde que não estivesse ou estivessem agindo em conformidade com as determinações do comando de greve ou do que fora acordado pela coalização de trabalhadores, sujeitar-lhe-á às sanções penais e cíveis cabíveis, mas não deverá levar à conclusão acerca da abusividade do movimento grevista. Esta é a conclusão que se extrai do seguinte julgado:

Sanções disciplinares aplicadas ao grevista. Limites. O movimento grevista visa primordialmente à manutenção da relação de emprego, lutando para o aprimoramento das condições de trabalho. Portanto, é preciso cautela no exame dessa matéria para não se invalidar o exercício constitucional do direito à greve, por entender que, participando de um movimento legítimo para a maioria, pratica o obreiro um ato capaz de lhe gerar sanções disciplinares. Logo não podemos visualizar na greve o aspecto individual, a não ser pelo comportamento distinto de cada empregado, pois ela é um fato coletivo. Além disso, há de serem observados os limites traçados pelo ordenamento jurídico (art. $9^{\circ}$, $\S \S 1^{\circ}$ e $2^{\circ}$, da CF/88 e Lei n. 7.783/89) (TRT $3^{\text {a }}$ Região, $7^{\mathrm{a}}$ Turma, RO 00066-2008-096-03-00-2 - Rela. Juíza Convocada Ana Maria Amorim Rebouças - DJMG 14.8.08)

E muito mais difícil do que definir o valor probandi de determinadas provas para justificar certas medidas de tutela preventiva é determinar qual o grau de prova exigível para justificar uma inibitória quando o ilícito ainda não ocorreu, havendo, no máximo, atos preparatórios. Ora é indiscutivelmente mais difícil provar o perigo de cometimento de um ilícito do que provar uma irregularidade que já ocorreu. Estabelecer critérios para valorar antecipadamente a idoneidade dos meios empregados nos atos de preparação de determinada infração é, seguramente, um dos maiores desafios dos estudos atinentes às tutelas preventivas. 
Após ponderar que o perigo de lesão que se exige não se confunde com o mero perigo genérico de que algum dia possa ocorrer a violação do direito, o que torna necessária a existência de uma situação específica que ameace a integridade do direito, Sérgio Cruz Arenhart apresenta reflexão acerca das duas alternativas existentes acerca da prova do dano que justifica a tutela preventiva. Em suas palavras, "ou se mantém indene a exigência da prova da ameaça, correndo o risco de inviabilizar a proteção preventiva do direito examinado, ou, ao revés, se dispensa esta prova, tornando a presente ação praticamente isenta de necessidade probatória”, o que autorizaria a solução imediata da controvérsia. Encarrega-se ainda de evidenciar a inadequação das duas soluções. A primeira porque gera o perigo de inefetividade de toda tutela preventiva. A segunda, embora apresente a vantagem de permitir a criação de procedimento incomparavelmente rápido, finda por dispensar o contraditório e franquer acesso ao judiciário daquele que nenhuma razão tem para bater as suas portas ${ }^{600}$. O autor finda por sugerir a utilização da técnica de "redução do módulo de prova", próprio das tutelas de urgência, segundo a qual "as provas não buscam a demonstração da existência de fatos (ou, ao menos, não buscam a criação de certeza na mente do julgador", mas apenas a indicação da possibilidade de sua efetiva ocorrência. Esta redução deverá, em sua opinião, incidir tanto na tutela inibitória final, quanto na tutela inibitória provisória ${ }^{601}$.

A sua conclusão é adequada ao conceito de tutela preventiva em geral. Encontra-se, inclusive, em bastante harmonia com a norma própria do artigo 933 do Código de Processo Civil que adotou para o interdito proibitório o rito especial previsto para as ações de manutenção e reintegração de posse.

Esta conclusão, entretanto, não pode se aplicar aos interdito proibitório relacionado com o exercício de greve. Ela é manifestamente incompatível com a conclusão já apresentada, da qual não se abre mão, de que em se tratando de ação relacionada com o exercício do direito de greve, cuja fundamentalidade é discutível e cuja eficácia e efetividade vem sendo reduzida pelo advento de novas técnicas empresariais, do advento de novas tecnologias, do aumento de importância da preocupação com os consumidores. Partindo da premissa de que em se tratando de ação preventiva em que se discute temas relacionados com o exercício do direito de greve, a interpretação deve ser sempre

\footnotetext{
${ }^{600}$ ARENHART, Sérgio Cruz. A tutela inibitória da vida privada. RT: 2000, p. 143.

${ }^{601}$ Ibidem, p. 145.
} 
direcionada para a garantia da realização da manifestação paredista, não há como admitir a sugerida técnica de redução do módulo da prova. Como bem salientou Jean-Emmanuel Ray, "utilisant délibérement la force et non le droit, de plus sur le plan collectif, le gréviste demande au juge un remarquable effort de comprehension, bien qu'il exerce um droit constitucionnel" ${ }^{\prime 602}$.

É possível, outrossim, concluir pela inadequação do interdito proibitório ao fim que se propõe, também por inadaptabilidade dos seus requisitos às peculiaridades próprias do exercício da greve. Corroborando esta conclusão, há que se reconhecer o fato de pouquíssimos interditos proibitórios relacionados com movimentos grevistas terem o seu mérito julgado. Na esmagadora maioria dos casos o resultado desejado é obtido com a liminar vez que o entusiasmo do movimento de trabalhadores arrefece e, quando finalmente o processo é chamado à conclusão para julgamento, a greve já não existe mais. Quando se chega a prolatar sentença, o único objetivo remanescente dela é a aplicação de multa por descumprimento de alguma medida liminar.

\subsubsection{Movimentos grevistas e violação ao direito de ir e vir}

Como já evidenciado, muitos interditos proibitórios são fundamentados em ameaças de violação ao direito de ir e vir dos não grevistas e dos clientes do estabelecimento. Como já se teve oportunidade de evidenciar, mas não é demais repetir, o que se busca tutelar na verdade não é o direito de ir e ver dos não grevistas e dos clientes, mas o direito dos consumidores de ter acesso ao serviço como se o movimento grevista inexistisse. Quando trabalhadores grevistas bloqueiam o acesso de clientes aos estabelecimentos de seu empregador, não os impede de ir à um concorrente, ou procurar uma solução alternativa para o seu problema. Os grevistas não praticam ato que lhes impeça de circular livremente pelo território nacional, apenas lhes impede de ter acesso a um serviço determinado.

No tocante aos não grevistas é possível sim que se esteja diante de uma violação ao seu direito ao trabalho. Quando ele efetivamente deseja ter acesso à agência para trabalhar e é impedido pelos grevistas, caracterizada está a violação. Não há dúvidas quanto a isso.

\footnotetext{
${ }^{602}$ RAY, Jean-Emmanuel. Le juge et les conflits collectifs de travail. Droit Social, n. 7-8 - Juillet-Août 1986, p. 619 .
} 
Cumpre questionar, entretanto, em quais situações efetivamente se está diante de uma violação ao direito do não grevista ao trabalho. A reestrução da engenharia organizacional das empresas tem gerado planos de cargos e salários em que o número de ocupantes de cargo de confiança muitas vezes supera o de trabalhadores que não apresentam esse grau de fidúcia. Há muitos chefes para poucos chefiados.

Quando eclode um movimento grevista, é essa maioria de ocupantes de cargo de confiança, que depende do valor extra correspondente à comissão pelo exercício da função, que deixa de participar da paralisação por recear reverter ao cargo anterior e perder aquela quantia fundamental para o pagamento de suas contas. Alguns por estarem efetivamente alinhados com o discurso do empregador. Outros, contudo, conquanto considerem o movimento justo, torçam pelo seu êxito e no fundo tentem desfarçar o seu desejo de estar ali participando com os colegas, continuam suas atividades laborais por um imperativo econômico, por precisar permanecer no cargo de confiança. Em um cenário como esse há que se questionar se houve efetiva violação ao direito ao trabalho do não grevista ou se o que se verificou foi uma reação natural à conduta antissindical travestida na imposição, por meios econômicos, de abstenção de participação no movimento sindical.

A solução proposta alhures, qual seja evitar a concessão de tutelas preventivas, deixando para analisar a abusividade da greve a partir da verificação dos danos efetivamente causados, da boa-fé das partes envolvidas nos dois lados do movimento, possibilita que em uma situação como essa se identifique a conduta antissindical do empregador e, a despeito, de ter havido efetivo óbice ao acesso de alguns trabalhadores ao posto de trabalho, reconheça-se a legitimidade do movimento.

O grande problema é que o judiciário, em expressivo número de casos, tem intervido, em juízo de cognição sumária e tutela preventiva, sem que exista prova da efetiva violação do direito ao trabalho. Como as aludidas ações são instruídas com prova documental e a liminar, quando efetivamente tem êxito, é prolatada antes da oitiva da outra parte, o órgão julgador decide a partir de relatos e fotos.

A tutela concedida para proteger a posse e a propriedade do empregador tampouco se justifica. O direito de greve, como já salientado, consiste justamente no direito de causar a outrem um prejuízo como forma de pressioná-lo a atender suas reivindicações. É evidente que o prejuízo a que se faz referência neste momento é o correspondente à 
paralisação das atividades, normalmente associado à ideia de lucros cessantes, não compreendendo a destruição de seu patrimônio. Para Mario Rusciano, no confronto entre direito de greve e direito de propriedade do empregador o movimento será legítimo quando se limitar a causar dano à produção, vista como resultado dia a adia da atividade empresarial. Não o será, entretanto, quando afetar a produtividade da empresa como um todo, vale dizer a sua potencial capacidade de competir no mercado ${ }^{603}$. Mas para saber se houve prejuízo à produtividade e não apenas à produção é necessário que o movimento tenha sido deflagrado. Não é possível, através de uma tutela inibitória como a dos interditos proibitórios, concluir que a produtividade da empresa será afetada. Antes da deflagração do movimento qualquer conclusão a este respeito não passará de mera suposição.

\subsection{DISSÍDIO DE GREVE}

Segundo Ronaldo Lima dos Santos, o dissídio coletivo de greve consiste na instauração da instância durante a deflagração de um movimento paredista para apreciação de controvérsias sobre a regularidade da greve e o julgamento das reivindicações que deram origem ao conflito. Em sua abalizada opinião, o dissídio coletivo também seria o palco para a apreciação de outras matérias correlacionadas com o movimento grevista, como a manutenção dos serviços cuja paralisação acarrete prejuízos irreversíveis ao empregador, o ressarcimento de danos morais e materiais difusos e coletivos ocasionados à coletividade ${ }^{604}$.

A partir desta definição é possível perceber que o dissídio coletivo afigura-se muito mais adequado para a solução de questões relacionadas com turbação à posse provocada por manifestações grevistas do que o interdito proibitório. Até porque, como salienta Aloysio Corrêa da Veiga, no interdito proibitório a cognição é sumária, não se questionando a greve, mas tão somente os atos praticados pelo grevista, não havendo, por conseguinte, espaço para se perquirir a abusividade da manifestação. Não há espaço para

\footnotetext{
${ }^{603}$ Lo sciopero sarebbe legittimo, quando <<si limita > - diciamo così - ad arrecare danno alla produzione, vista come risultato giorno per giorno dell'attività dell'azienda; non lo sarebbe, invece, quando dovesse compromettere la produttività dell'azienda stessa, vale a dire la sua potenziale capacità a stare utilmente sul mercato. In tale distinzione, mi pare di poter senz'altro individuare l'idea del contemperamento tra interesse dei lavoratori e interesse dell'impresa. (RUSCIANO, Mario. Diritto di sciopero e assetto costituzionale. Rivista italiana di diritto del lavoro, anno XXVIII, 2009, I, p. 63).

${ }^{604}$ SANTOS, Ronaldo Lima dos. Sindicatos e ações coletivas: acesso à justiça coletiva e tutela dos interesses difusos, coletivos e individuais homogêneos. $2^{\mathrm{a}}$ ed. São Paulo: LTr, 2008, p. 284/285.
} 
analisar se os atos de convencimento, permitidos em lei, estão sendo praticados de forma contrária ao bem comum ${ }^{605}$.

Veiga sugere que em situações emergenciais seja feito uso de uma ação cautelar, incidental ou preparatória do dissídio coletivo, com pedido de liminar e cominação de astreintes para coibir o excesso da manifestação. Ressalta que a cognição seria mais ampla e preparatória do dissídio coletivo de greve, pondendo na aludida cautelar conhecer todo o exercício do direito de greve, inclusive quanto à sua abusividade ${ }^{606}$.

A polêmica acerca da competência do juízo de primeiro grau restaria solucionada na medida em que a competência para conhecer da ação cautelar seria dos Tribunais Regionais do Trabalho, porque preparatória do dissídio de greve. Isso terminaria por retirar a grande quantidade de ações de interdito proibitório, não se encerraria apenas na concessão da liminar do mandado e não traria, em sua opinião, a desconfiança de se impedir o movimento grevista ${ }^{607}$. Também pugnando pela substituição dos interditos proibitórios por medidas cautelares atencipatórias ou incidentais de dissídio coletivo, ajuizadas perantes os Tribunais e não perante os juízos monocráticos, posicionou-se Ronaldo Lima dos Santos ${ }^{608}$. Embora sem enfrentar diretamente a questão ora posta em discussão, Everaldo Gaspar Lopes de Andrade reconhece a possibilidade de o empregador ajuizar ação cautelar em dissídio coletivo para tutela de seus interesses, asseverando que "mesmo sendo o pedido solicitado pelo órgão patronal, deve ele interessar aos empregados, evitando que haja futuras alegações de descumprimento de norma de ordem pública, especialmente, quando está em jogo a vida e a saúde das pessoas ${ }^{609}$.

Esta solução afigura-se, por todas as razões acima listadas, bem mais adequada do que o ajuizamento de interditos proibitórios. Ela não supera, contudo, o inconveniente gerado pela dificuldade de se harmonizar tutela preventiva com direito de greve, sem que haja o esvaziamento deste.

\footnotetext{
${ }^{605}$ VEIGA, Aluysio Corrêa da Veiga. O Direito de greve e o interdito proibitório. In: BOUCINHAS FILHO, Jorge Cavalcanti; PEREIRA, José Luciano de Castilho; FAVA, Marcos Neves. $O$ direito material $e$ processual do trabalho dos Novos Tempos: estudos em homenagem ao Professor Estêvão Mallet. LTr, 2009, pp $25 / 49$.

606 Ibidem, p. 36.

607 Ibidem, p 25/49.

${ }^{608}$ SANTOS, Ronaldo Lima dos. Op cit. p. 82.

${ }^{609}$ ANDRADE, Everaldo Gaspar Lopes de. Dissídio coletivo. São Paulo: LTr, 1993, p. 200.
} 
Ora, se a ação cautelar for preparatória do dissídio coletivo, ajuizada, portanto, antes da efetiva deflagração da greve, o provimento concedido poderá efetivamente implicar em violação ao direito dos manifestantes. Basta, para tanto, que, em se presumindo a abusividade da greve, um Tribunal, e não mais um juízo de primeiro grau, conceda um provimento que interfira no direito de greve. Para não repetir muitos dos erros cometidos nos julgamentos dos interditos proibitórios, é salutar que as liminares em cautelares preparatórias, ajuizadas antes da deflagração do movimento, sejam evitadas.

Independentemente de ser concedido em sede de interdito proibitório ou de cautelar preparatória de dissídio coletivo de greve, independentemente de ser concedido por um juízo singular ou por órgão colegiado, qualquer "ordem", "comando" ou "injunção" que interfira no direito dos manifestantes de definir como será feita sua manifestação, como, por exemplo, obstando realização de assembleia na frente das empresas, panfletagem, impedindo a utilização de carros de som, autorizando a utilização de força policial, apenas para citar alguns exemplos, acaba enfraquecendo o movimento e violando o direito constitucionalmente garantido.

Ora, o artigo $9^{\circ}$ da Constituição Federal assegura em seu caput o direito de greve, "competindo aos trabalhadores decidir sobre a oportunidade de exercê-lo e sobre os interesses que devam por meio dele defender", e em seus parágrafos estatui que "a lei definirá os serviços ou atividades essenciais e disporá sobre o atendimento das necessidades inadiáveis da comunidade" e que "os abusos cometidos sujeitam os responsáveis às penas da lei”. A partir deste preceito só é possível admitir tutela preventiva em matéria de direito de greve para assegurar o atendimento das necessidades inadiáveis da comunidade. Excepcionalemente, quando houver uma grande ameaça de dano a outro direito fundamental poder-se-á pensar em tutela preventiva a requerimento, por exemplo, do empregador. Essa, contudo, não deve ser a regra geral. Como já salientado, deve-se primar para que a intervenção do judiciário nos movimentos grevistas seja preferencialmente repressiva, posterior, portanto, à deflagração do movimento.

Augusto César Leire de Carvalho entende improváveis as hipóteses de cabimento do interdito proibitório em meio à greve e considera que o empregador pode assegurar o seu ingresso no estabelecimento empresarial ou a utilização de equipamentos usualmente 
operados por não grevistas por meio de petições incidentes no dissídio coletivo porventura já instaurado ${ }^{610}$.

Esta solução parece mais adequada à reflexão posta. O único adendo a ser feito a esta observação é o de que a medida em questão será um requerimento de antecipação de tutela. Como salienta Estêvão Mallet, “o dissídio coletivo é processo, como outro qualquer, sendo antecipável a tutela que nele se busca realizar" ${ }^{\text {"611 }}$. Ora, sendo o pedido principal de reconhecimento da irregularidade da greve, nada mais adequado do que, havendo dano à produtividade da empresa, e não a sua produção, efetivo cerceamento do direito de ir e vir dos não grevistas e excessivos danos a terceiros, nada mais adequado do que antecipar este provimento final, reconhecendo a abusividade da greve e determinando a cessação das manifestações sob pena de multa.

A opção pela cautelar incidental, em verdade, não destoa do que fora afirmado. Ele se prestaria ao mesmo papel do requerimento de antecipação de tutela. É forçoso, contudo, reconhecer que até mesmo pela praticidade e simplicidade, esta solução afigura-se mais adequada do que aquela. O que não se afigura razoável é a concessão de cautelar preparatória do dissídio de greve, pois nesta hipótese estaríamos novamente na seara da tutela preventiva e da presunção de abusividade do movimento grevista.

No tocante ao provimento para assegurar a manutenção e o atendimento das necessidades inadiáveis da comunidade, entendemos dever ele ser postulado com exclusividade pelo Ministério Público do Trabalho, em tutela antecipada, no próprio dissídio coletivo de greve, consoante dispõe o artigo $114, \S 3^{\circ}$ da Constituição ${ }^{612}$. A explicação é simples. O dissídio de greve em atividades essenciais ajuizado pelo Ministério Público do Trabalho após o advento da Emenda Constitucional 45 tem por finalidade justamente assegurar o atendimento das necessidades inadiáveis da comunidade. Eventual dissídio coletivo ajuizado pelo empregador deverá limitar a discussão acerca da abusividade ou não do movimento paredista. Como falta ao empregador legitimidade para ajuizar uma ação em defesa de um interesse da coletividade, a ação ajuizada por ele deverá

${ }^{610}$ CARVALHO, Augusto Cesar Leire de. Direito fundamental de greve e interdito proibitório. In: ARRUDA, Kária Magalhães; COSTA, Walmir Oliveira da (coordenadores). Direitos coletivos do trabalho na visão do TST: homenagem ao Ministro Rider Nogueira de Brito. São Paulo: LTr, 2011, p. 14.

${ }^{611}$ MALLET, Estêvão. A atencipação da tutela no processo do trabalho. $2^{\mathrm{a}}$ ed. São Paulo: LTR, 1999, p. 33.

${ }^{612} \S 3^{\mathrm{o}} \mathrm{Em}$ caso de greve em atividade essencial, com possibilidade de lesão do interesse público, o Ministério Público do Trabalho poderá ajuizar dissídio coletivo, competindo à Justiça do Trabalho decidir o conflito. 
se limitar aos aspectos econômicos decorrentes da greve, caso venha ela a ser declarada abusiva.

Em qualquer das duas hipóteses não se deve exigir o comum acordo como condição para ajuizamento da ação. A uma porque nem a Emenda Constitucional n. 45/2004 nem qualquer outro dispositivo normativo exigem tal pressuposto. A duas porque a natureza jurídica da sentença normativa proferida na ação coletiva ora tratada é predominantemente declaratória da regularidade ou não do exercício do direito de greve, independentemente de o dissídio haver sido instaurado pelas partes da relação capital-trabalho ou pelo Ministério Público e muito menos que a atividade atingida pela paralisação do trabalho seja essencial ou não ${ }^{613}$. Eventual cominação condenatória não passará de uma decorrência da tutela declaratória.

Muito ainda se discute na doutrina e na jurisprudência acerca da cognição dos Tribunais do Trabalho no julgamento do dissídio coletivo de greve. Poderiam eles, em julgando o movimento não abusivo, decidir sobre a procedência total ou parcial ou improcedência das reivindicações? Há decisões admitindo esta possibilidade ${ }^{614}$.

Em termos doutrinários, Raimundo Simão de Melo, acompanhando o entendimento de Ronaldo Lima dos Santos, que transparece da definição feita alhures, afirma textualmente a possibilidade de definição das cláusulas econômicas em dissídio de greve, temperando que a sentença proferida num Dissídio Coletivo, de qualquer natureza, tem importante função social, qual seja, resolver a pendência e restabelecer a harmonia entre as partes envolvidas. E indaga:

\footnotetext{
${ }^{613}$ Referido autor respalda suas conclusões no seguinte precedente do Tribunal Regional do Trabalho da $2^{\mathrm{a}}$ Região: A questão referente ao comum acordo somente vem a ser exposta no $\S 2^{\circ}$, como complemento direto ao caput, e não como restrição retroativa ao precedente inciso II. Se o legislador pretendesse - argumentando com o absurdo - condicionar a instauração do dissídio coletivo de greve ao entendimento prévio dos litigantes, teria inserido a ressalva no próprio inciso II. O texto do $\S 2^{\circ}$ não deixa margem a dúvidas quanto à evidência de que a locução de comum acordo diz respeito a uma faculdade outorgada as partes para o ajuizamento de dissídio coletivo de natureza econômica, quando resultarem frustradas suas tentativas de negociação coletiva ou de arbitragem extrajudicial. De qualquer forma, não se pode forjar uma antinomia entre o art. 114 e a cláusula pétrea da indeclinabilidade da jurisdição, contemplada no inciso XXXV do art. $5^{\circ}$ da Carta Magna, resumida no princípio segundo o qual a lei não excluirá da apreciação do Poder Judiciário lesão ou ameaça a direito (TRT/SP - DCG 20086. 2005.000.02.00-9, Rela. Juíza Wilma Nogueira de Araújo Vaz da Silva apud MELO, Raimundo Simão de. A greve no direito brasileiro. São Paulo: LTr, 2006, p. 148).

${ }^{614}$ Pedidos econômicos e sociais em dissídio coletivo de greve: ação com natureza de dissídio coletivo de greve obviamente possui um objeto que, no caso, é traduzido por condições econômicas e sociais. (TRTSPDCG 2008.2005.000.02.00-9, Relatora Juíza Wilma Nogueira de Araújo Vaz da Silva)
} 
Para que serve uma decisão da Justiça do Trabalho dizendo apenas que a greve é abusiva ou ilegal? A resposta é simples: haverá maior agravamento do conflito, porque o que querem as partes, especialmente os trabalhadores, é a solução do conflito. Se não for para isso, não precisará mesmo existir solução heterônoma de conflitos coletivos de trabalho pelos Tribunais ${ }^{615}$.

A solução proposta apresenta um inconveniente de ordem formal. Sendo diferentes os requisitos para o ajuizamento de dissídio coletivo de greve e de dissídio coletivo de natureza econômica, o julgamento daquele como se fosse este possibilitaria que empregadores suscitassem dissídios de greve apenas para conseguir uma sentença normativa apesar da não outorga do comum acordo pela parte contrária ${ }^{616}$, a representação dos trabalhadores. Este impasse, contudo, é facilmente superável. Basta que no curso do dissídio de greve as partes sejam notificadas para se manifestar, ou o façam expressamente em audiência, acerca da concordância com o julgamento imediato da questão. Em havendo concordância das partes com o julgamento imediato das questões econômicas, fazê-lo é seguramente a medida mais consentânea com os princípios da economia processual e instrumentalidade do processo.

\subsection{AÇõES PREVENTIVAS VISANDO SAVALgUARDAR O DIREITO DE GREVE}

Segundo Giovanni Orlandinni a natureza social do direito de greve não deixa espaço para o exercício discricionário do poder legislativo para garantir a eficácia das normas constitucionais sobre direito social. Em suas expressas palavras "La sua natura di diritto 'autosufficente' garantisce ai titolari di agire in giudizio contro atti o comportamenti che ne limitino l'esercizio, in forza del solo disposto costituzionale" ${ }^{\prime 617}$.

Aparentemente compartilhando das ideias do autor italiano, diversos sindicatos brasileiros, ao verem suas ações minadas pela enxurrada de interditos proibitórios,

\footnotetext{
${ }^{615}$ MELO, Raimundo Simão de. A greve no direito brasileiro. São Paulo: LTr, 2006, p. 149.

${ }^{616}$ Sobre a exigência de comum acordo na Justiça do Trabalho ver BOUCINHAS FILHO, Jorge Cavalcanti. A atual dimensão do debate sobre o ajuizamento do dissídio coletivo de comum acordo. A tese da inconstitucionalidade da exigência do impulso bilateral. Jus Navigandi, Teresina, ano 13, n. 1792, 28 maio 2008. Disponível em: 〈http://jus.com.br/revista/texto/11315>. Acesso em: 2 jan. 2012.

${ }^{617}$ ORLANDINI, Giovanni. Sciopero e servizi pubblici essenciali nel processo d'integrazione europea: uno Studio di diritto comparato e comunitário. Torino: Giappichelli editore: 2003, p. 23.
} 
passaram a eles próprios ajuizar diversos tipos de procedimentos judiciais buscando obter alguma garantia para o exercício do seu direito de greve.

Uma confederação brasileira de trabalhadores pleiteou ao STF, através de uma ação de descumprimento de preceito fundamental, uma interpretação conforme o texto constitucional para que se considerem lesiva a utilização do artigo 932 do Código de Processo Civil para proteger a posse em casos que se refiram às paralisações de trabalhadores. Outras entidades sindicais prelitearam ingresso nesta ação na condição de amicus curae 618 .

Também há registros de diversas ações civis públicas ajuizadas para garantir o exercício do direito de greve, por meio de garantia judicial da formação de linhas de piquete e, ainda, na tentativa de obstar práticas antissindicais utilizadas pelas grandes instituições financeiras para impedir a adesão dos empregados à paralisação. Pedem ainda a garantia de ingresso no interior de cada estabelecimento para que pratiquem o exercício do convencimento dos trabalhadores não aderentes. Os resultados não têm sido favoráveis aos sindicatos dos trabalhadores ${ }^{619}$.

Cabe registrar ainda o ajuizamento de mandados de segurança como sucedâneo recursal para impugnar a decisão liminar proferida em sede de interdito proibitório.

Determinado sindicato de São Paulo, Osasco e Região ajuizou reclamação trabalhista com pedido de antecipação de tutela contra instituição financeira, tombada com o número 02163.2010.004.02.00.1, visando provimento jurisdicional que lhe assegurasse o livre exercício do direito de greve. Alegou, na ocasião, que o seu direito de greve encontrava-se ameaçado na medida em que todos os anos o réu ingressa com interdito proibitório na Justiça Comum com o único objetivo de impedir as manifestações, impor a presença de empregados no trabalho e enfraquecer o movimento e obém liminares assecuratórias do livre funcionamento e acesso de trabalhadores, clientes e usuários, com a proibição de manifestação nas proximidades das agências. Esperava, ao final que fosse declarado seu direito a utilização de meios pacíficos para o livre convencimento dos seus colegas e da população, inclusive através da utilização de megafones e carros de som, assim como o ingresso nos locais de trabalho para a distribuição de material e informes,

${ }^{622}$ CRIVELLI, Ericson. Interditos proibitórios versus liberdade sindical - uma visão panorâmica do direito brasileiro e uma abordagem do direito internacional do trabalho. Revista LTr. 73-12/1426.

${ }^{619}$ Ibidem, p. 1427. 
bem como postarem-se em frente às agências e lá permanecerem, garantindo-se o exercício integral dos direitos arrolados no artigo $6^{\circ}$ da Lei de Greve.

A ação foi extinta sem resolução do mérito por falta de interesse de agir. A julgadora fundamentou sua decisão no fato de a lei já assegurar a utilização de meios pacíficos tendentes a persuadir ou aliciar os trabalhadores a aderirem à greve e vedar a adoção de meios para constranger o empregado ao comparecimento ao trabalho, o que torna desnecessário pronunciamento jurisdicional para garantir o cumprimento da lei, sem que haja prova de violação a essas garantias.

A utilização dos referidos recursos é mais uma demonstração de criatividade na contraofensiva dos trabalhadores à ofensiva dos empregadores verificada através da utilização dos interditos proibitórios. Há que se reconhecer que essas ações consistem em reação natural da representação de trabalhadores que, de uma hora para outra, se viu sem meios de utilizar plenamente o seu mais relevante e importante instrumento de pressão.

Isso não significa, contudo, que aludidas ações devam ser julgadas procedentes. A greve surge como um fato natural. Modernamente diz-se que é um ato jurídico, fruto de declaração de vontade da maioria obreira ${ }^{620}$. Não é preciso, portanto, ação para se obter autorização para realização de greve. A jurisprudência brasileira já pacificou, inclusive, o entendimento acerca da ilegitimidade do sindicato profissional para requerer judicialmente a qualificação legal de movimento paredista que ele próprio fomentou ${ }^{621}$.

A aceitação desse tipo de ação, que seguramente não impediria a concessão de liminares em interditos proibitórios quando, por distribuição, as ações chegassem a julgadores distintos, apenas serviria para alimentar a guerra de propagandas travada entre trabalhadores e empregador. Aqueles utilizando a decisão proferida em uma das ações mencionadas para convencer as pessoas de que o movimento havia sido declarado legítimo e que eles estavam judicialmente autorizados a realizar suas manifestações. Estes utilizando as liminares em interditos proibitórios com fins semelhantes, mas objetivando, naturalmente, a atender seus interesses.

\footnotetext{
${ }^{620}$ GARCIA, Paulo. Direito de greve. Rio de Janeiro: Edições trabalhistas s.a, 1961, p. 112.

${ }^{621}$ Nesse sentido é a Orientação Jurisprudencial n. 12 da SDC-TST, que assim dispõe : “Greve. Qualificação jurídica. Ilegitimidade ativa ad causam do sindicato profissional que deflagra o movimento. Não se legitima o sindicato profissional a requerer judicialmente a qualificação legal de movimento paredista que ele próprio fomentou"
} 


\subsection{COGNIÇÃO JUDICIAL NAS AÇÕES DE DIREITO DE GREVE}

Márcio André Medeiros Moraes assevera que o julgador que se depara com ações relacionadas ao exercício do direito de greve deve agir com cautela, de modo a evitar o cometimento de injustiças, agindo com sensibilidade suficiente para saber discernir as ações que visam apenas e tão somente obstruir o direito de greve. Deve evitar que os empregadores usem o instituto da responsabilidade civil para punir determinados trabalhadores grevistas e sindicatos de forma indiscriminada ${ }^{622}$. Finaliza destacando o papel da jurisprudência na fixação de limites à prática do exercício do direito de greve, evitando ônus excessivo a todos que, porventura, possam ser atingidos pelo movimento grevista $^{623}$.

A conclusão que decorre dos estudos feitos ao longo do desenvolvimento desta tese é, contudo, diversa. Diante da relevância do direito de greve, não apenas para as conquistas dos trabalhadores, mas como efetivo instrumento de exercício democrático, a ideia que se apregoa aqui é a de que a intervenção do judiciário nos movimentos grevistas deve ser mínima. Quando ocorrer deverá ser sempre direcionada a garantir o exercício das manifestações, como, por exemplo, quando determina a reintegração de delegado sindical $^{624}$ indevidamente dispensado, impede a transferência de trabalhadores em represália às manifestações realizadas em determinado estabelecimento e inibe a

\footnotetext{
${ }^{622}$ MORAES, Márcio André Medeiros. A responsabilidade civil do sindicato perante o consumidor. 2001. 377 f. Tese (doutorado em Direito das Relações Sociais - Direito Civil). Pontíficia Universidade Católica de São Paulo, São Paulo, 2001, p. 5/6.

${ }^{623}$ Ibidem, p. 137.

${ }^{624}$ Sobre a missão do delegado sindical ver: SALVAGE, Philippe. Les attributions du délégué syndical en cas de grève. Droit Social, n. 7/8, Juillet-Août 1986, p. 624-634. Neste texto enaltece-se o importante papel do delegado sindical e afirma-se, a título de conclusão: "Si le droit de grève, en France, n'appartient pas juridiquement au mouvement syndical, la grève n'obéissant pas à une conception organique, l'examen des fait démontre à peu près toujours le rôle essentiel joué par les syndicats et leurs délégués à l'occasion d'un conflit collectif. De telle sorte que le droit, à travers la loi et plus encore la jurisprudence et la doctrine, a été progressivement conduit au cours de ces dernières années à reconnaître voire à officializer ce rôle. L'evolution suivie apparaît à cet égard inéluctable et non susceptible de revirement. Aujourd'hui, la jurisprudence en vient à reconnaître que dans la mesure où la grève a été <<inspirée, commencée et exécutée〉> par une organisation syndicale, elle deviant elle-même une <<activité syndicale〉>, ce qui est de nature à permettre d'en protéger pénalement l'exercice contre les atteintes dont elle peut faire l'objet, notamment de la part de l'employer. Cette jurisprudence, loin de se limiter à la reconnaissance d'un état de fait, ouvre au délégué syndical des possibilites supplémentaires d'ailleurs encore mal explorées. L'évolution en matière ne parait, en effet, pas définitivement achevée. Une foi encore, c'est essentiellement au délégué syndical, pivot de l'action collective, qu'il appartiendra de la mener positivement à son terme car sa prééminence par rapport aux autres représentants du personnel s'affirme avec netteté. On l'avait démontré hors conflit, on peut désormais affirmer qu'il en va de même en cas de grève". Sobre o mesmo assunto há também o seguinte texto: BÉRAUD, Jean-Marc. Le rôle des délégués en cours de grève. Droit social, n. 910, Septembre-Octobre 1988, p. 666-671.
} 
substituição dos trabalhadores por outros ou por máquinas. Ele poderá intervir em favor da comunidade para assegurar o atendimento de suas necessidades inadiáveis, sendo esta a hipótese por excelência de intervenção judicial preventiva no movimento grevista. Outras hipóteses, sempre excepcionais e devidamente bem fundamentadas, poderão surgir na análise de determinados casos concretos. Não deverão, contudo, ser tratadas como regra.

A orientação geral deve ser, portanto, de tutela do movimento grevista, intervindo, a requerimento da representação dos trabalhadores, para impedir e depois sancionar condutas antissindicais que impeçam a eclosão e a manutenção do movimento. Uma vez deflagrado, poderá o judiciário intervir para o reconhecimento da abusividade da greve, a partir de critérios já propostos e aplicando as sanções que serão analisadas em item seguinte e para sancionar eventuais abusos ao exercício do direito de greve. A intervenção em favor da comunidade, ai englobando-se consumidores e usuários esporádicos dos serviços prestados pelos grevistas, deve ser a mínima possível. Deve-se limitar às hipóteses de atividades essenciais que, como visto, devem ser interpretadas restritivamente, e apenas para assegurar o atendimento de necessidades inadiáveis.

Poder-se-á questionar se a solução proposta não acaba criando algum favorecimento aos trabalhadores. A resposta a ser dada é a de que a solução proposta prima para que um direito assegurado constitucionalmente aos trabalhadores possa ser exercido livremente. O objetivo é criar meios para possibilitar que o conflito ecloda, assegurando aos trabalhadores poder de pressão sobre o empregador na expectativa de que, a partir dos resultados obtidos com esse movimento, as paralisações se tornem desnecessárias nos anos seguintes por terem as partes conseguido alcançar uma solução autocompositiva sem que o recurso a greve fosse acionado. Como afirma Mario Rasciano, não se trata "di preferire il conflito alla pace sociale; si trata, se mai, di preferire l'emersione del conflito, così com'è dandone per scontate, senza infigimenti, la inevitabilità e la insopprimibilità - piuttosto che una finta pace sociale, magari ottenuta com le cariche della polizia"625.

A responsabilidade depositada nos magistrados trabalhistas em cada julgamento, independentemente da matéria envolvida, é absolutamente imensurável. Em suas mãos está depositada a confiança de toda a sociedade, e de forma particularmente especial, a dos jurisdicionados envolvidos no caso em tela. A vida e a subsistência de famílias inteiras

${ }^{625}$ RUSCIANO, Mario. Diritto di sciopero e assetto costituzionale. Rivista italiana di diritto del lavoro, 2009, I. G, p. 52. 
depende de seu preparo técnico e emocional ${ }^{626}$. Essa importância se acentua quando se está diante de uma ação coletiva de qualquer natureza. A relevância dos direitos envolvidos e a repercussão social da decisão proferida potencializam a responsabilidade do julgador.

Esta situação adquire particular relevo no tocante às ações em que se discute o direito de greve, haja vista a importância dos direitos em jogo e dos inevitáveis conflitos entre direitos fundamentais de diversos gêneros que se verificam neste tipo de movimento, como demonstrado nos capítulos precedentes. Afinal, invertendo-se completamente a lógica aqui defendida como adequada, a maioria das ações que tratam do tema discutem limitações ao direito de greve e não meios de assegurar o seu exercício. Como salienta Jorge Luiz Souto Maior, "no caso da greve os limites impostos muitas vezes geram a consequiência paradoxal de impedir-lhes o efetivo exercício. O direito de greve, sem uma reflexão atenta dos aplicadores da norma, pode ser a própria negação da greve como direito" 627 .

A solução proposta não se distancia do que fora apregoado pela Declaração Sociolaboral do Mercosul que estatui que "Os mecanismos de prevenção ou solução de conflitos ou a regulação deste direito não poderão impedir seu exercício ou desvirtuar sua finalidade".

Tampouco destoa do modelo adotado em outros países com maior tradição na organização de movimentos grevistas. Na França, mesmo em casos de efetiva ocupação dos locais de trabalho, ou seja, em que já não se trata mais de tutela preventiva, mas efetivamente reparatória, a jurisprudência apresenta grande preocupação em conseguir conciliar a liberdade de trabalho dos não grevistas com o direito de greve daqueles que desejam trabalhar e o direito de propriedade do empregador afetado por esta modalidade de greve $^{628}$.

\footnotetext{
${ }^{626}$ Sob este aspecto cabe fazer uma reflexão acerca dos programas de metas instituídos pelo Conselho Nacional de Justiça. Não obstante eles apresentem a inegável virtude de acelerar a prestação jurisdicional, há que se recear a redução das importantes questões colocadas em pautas nos processos judiciais em trâmite no Brasil à estatísticas numéricas. Eles estimulam uma desmesurada preponderância da celeridade e uma excessiva valorização da estatística. Não se pode, contudo, olvidar que por trás destes números há questões de extrema importância para a sociedade e para os envolvidos. Tratá-las como mais um número numa planilha pode ter conseqüências sociais absolutamente indesejáveis.

${ }^{627}$ MAIOR, Jorge Luiz Souto. O direito de exercer o direito de greve. In: THOMÉ, Candy Florêncio e SCHWARZ, Rodrigo Garcia. Direito coletivo do trabalho: curso de revisão e atualização. Rio de Janeiro: Elsevier, 2010, p. 255.

${ }^{628}$ SAVATIER, Jean. Expulsion et licenciement des grévistes occupant des locaux du travail. Droit social,n. 3, mars 1978, p. 126.
} 
É interessante observar que na França a preocupação que se tem ao se falar em expulsão dos grevistas é com a liberdade do trabalho dos não grevistas. Conquanto o empregador, à primeira vista, não tenha legitimidade para se beneficar de entraves a esta liberdade, admite-se que ele proponha a ação de référé por se reconhecer sua obrigação de fornecer trabalho ao seu pessoal, decorrente do contrato de trabalho. Como a ocupação dos locais de trabalho pode impedi-lo de executar sua obrigação, resta-lhe comprovar que fez o possível para cessar a ocupação, inclusive apresentando uma demanda perante o judiciário, mas não obteve êxito por motivo de força maior ${ }^{629}$.

O direito de propriedade sobre os imóveis e sobre as máquinas da empresa só é posto em discussão em situações excepcionais, quando a ocupação impede o empregador de exercer o poder de direção de chefe da empresa. Nestes casos pontuais, entende-se que o direito de greve não deve permitir a substituição do poder patronal pelo poder de fato dos dirigentes do movimento grevista, quer eles se confundam ou não com o dos representantes sindicais dentro da empresa. Entende-se forçoso admitir que os grevistas, sobretudo se não representarem mais que pequena fração do pessoal da empresa, pratiquem uma ocupação com longa duração e geral na empresa, paralisando o exercício de todo poder de direção pelo empregador. Mas, inversamente, os grevistas não se encontram excluídos da empresa pelo simples fato de fazerem pressão ao empregador. Sendo eles membros da empresa e lá possuindo, por intermédio de seus representantes eleitos e de seus representantes sindicais, os direitos que possibilitam limitar o poder do chefe da empresa, não se pode tratá-los como estrangeiros penetrando indevidamente em uma propriedade contra a vontade do proprietário. O problema é organizar, durante a greve, as ligações entre a direção, de uma parte, os grevistas e o pessoal não grevista de outra parte e não eliminar sistematicamente os grevistas da empresa ${ }^{630}$.

É interessante observar que enquanto no Brasil manifesta-se preocupação com a concessão de medidas preventivas para impedir a ocupação de estabelecimentos de trabalho ou mesmo impedir que os grevistas criem embaraços para que os não grevistas não cheguem às agências, na França busca-se formas de legitimar a ocupação harmonizando-a com a continuidade da prestação de serviços.

\footnotetext{
${ }^{629}$ Ibidem, p. 125.

${ }^{630}$ SAVATIER, Jean. Expulsion et licenciement des grévistes occupant des locaux du travail. Droit social,n. 3, mars 1978, p. 125.
} 
Jean Savatier fundamenta a sua preocupação com a expulsão de grevistas dos locais de trabalho no fato de ela não por fim ao conflito coletivo, podendo, eventualmente agraválo. Por mais respeitáveis que sejam os direitos de propriedade do empregador, o realismo impõe a constatação de que a melhor maneira de lhe permitir fazer uso dele é criar condições de perseguir na exploração da empresa. Esta solução se mostra mais interessante do que esvaziar a empresa dos trabalhadores sem os quais ela não poderá funcionar. $\mathrm{O}$ autor observa ainda não haver urgência em cessar a ocupação se essa não criar empecilhos para a continuidade da atividade da empresa ${ }^{631}$.

Savatier entende que não se pode tratar toda ocupação de locais de trabalho, independentemente da duração e das modalidades, como uma via de fato que justifique a expulsão imediata e total dos grevistas. Conforme a gravidade do atentado às prerrogativas do chefe da empresa, à liberdade do trabalho dos não grevistas, à segurança das pessoas e dos bens, conforme também as perspectivas de evolução do conflito, o órgão julgador competente poderá determiná-la ou não. Poderá, conforme o caso, adotar outras medidas que lhes pareça corresponder melhor às necessidades do caso. Uma possibilidade seria determinar que os grevistas se abstivessem de criar obstáculos ao trabalho dos não grevistas e as atividades da direção, ou que ficassem obrigados a manter as coisas no estado em que se encontravam antes da ocupação ${ }^{632}$.

Na França a discussão tem, já há alguns anos, girado em torno da definição das sanções que podem ser aplicadas aos autores da ocupação. Um antigo precedente da jurisprudência francesa, de 23 de maio de $1953^{633}$ declara que se a ocupação não estiver suficientemente caracterizada, o trabalhador que dela participar não comete irregularidade, o que permite concluir pela ocorrência de falta grave quando o trabalhador participar de uma greve caracterizada como tal. Em outro precedente, desta feita datado de 20 de maio de $1955^{634}$, considerou que a simples participação em uma greve que comporta a ocupação dos locais de trabalho não estabelece punição por falta que justifique a ruptura do contrato de trabalho.

\footnotetext{
${ }^{631}$ Ibidem, p. 125.

632 SAVATIER, Jean. Expulsion et licenciement des grévistes occupant des locaux du travail. Droit Social,n. 3, mars 1978, p. 125.

${ }^{633}$ Dr. Soc. 1953, 410 apud SAVATIER, Jean. Expulsion et licenciement des grévistes occupant des locaux du travail. Droit Social, n. 3, mars 1978, p. 125/126.

${ }^{634}$ Gaz. Pal. 1955, 2, 49 Ibidem.
} 
De igual maneira se considerou que os trabalhadores de um canteiro naval, que se mantiveram ao redor de um cais de lançamento de um navio, que era qualificado pelo empregador como ocupação dos locais de trabalho por força, não foi considerado como abuso do direito de greve ${ }^{635}$. Também não foi qualificada de falta grave a ocupação momentânea e limitada do trajeto entre o atelier central e os corredores de acesso ao escritório do diretor, durante uma manifestação coletiva de reinvindicações ${ }^{636}$.

Essas diversas espécies não correspondem a movimentos de ocupação caracterizados como tal e duráveis da empresa. Savatier destaca que, em razão da dificuldade em estabelecer uma discriminação entre todos que participem de um movimento coletivo, são poucos os julgados que reconhecem a validade das dispensas aplicadas pelos empregadores aos participantes de um movimento de ocupação ${ }^{637}$.

As decisões proferidas no caso Paris-Rhône pela Corte de Lion e pelo Tribunal Administrativo daquela vila são muito interessantes. Eles validaram dispensas por justas causas aplicadas a trabalhadores que participaram da ocupação de uma usina durante uma greve $^{638}$. Os fundamentos da decisão merecem análise. Não se tratou de sancionar um atentado ao direito de propriedade do empregador. O que a Corte de Lion reprovou foi o fato de os trabalhadores terem mantido a ocupação da usina ignorando decisão judicial que determinou sua expulsão. O fato de os trabalhadores manifestantes terem impedido a entrada de não grevistas mediante uso de força também foi levado em consideração para o reconhecimento da ilicitude da ocupação e a caracterização da falta grave. Adotando entendimento semelhante o Tribunal administrativo de Lion concedeu uma autorização de dispensa a quatro representantes do pessoal que participaram de uma ocupação. $O$ fundamento para a concessão foi o fato desses trabalhadores terem violado à liberdade de trabalho ao impedir que fração considerável de trabalhadores não grevistas chegassem ao seu local de trabalho ${ }^{639}$.

É possível afirmar que a falta grave cometida pelos grevistas foi a violação à liberdade de trabalho pela imposição de obstáculo dos que não participaram do

\footnotetext{
${ }^{635}$ Soc. 20 janv. 1956, Dr. Soc. 1956, 287. Ibidem.

${ }^{636}$ Soc. 11 fév. 1960, D. 1960, p. 603. Ibidem.

${ }^{637}$ SAVATIER, Jean. Expulsion et licenciement des grévistes occupant des locaux du travail. Droit Social,n. 3, mars 1978, p. 126.

${ }^{638}$ SAVATIER, Jean. Expulsion et licenciement des grévistes occupant des locaux du travail. Droit Social,n. 3, mars 1978, p. 126.

${ }^{639}$ Ibidem.
} 
movimento. A Corte de Cassação qualificou de falta grave a participação em piquetes de greve que impediram a entrada de empregados que desejavam trabalhar ${ }^{640}$. No caso ParisRhône também os obstáculos colocados à entrada dos não grevistas, com o risco de resultarem em violência, foi considerado uma falta grave. A ocupação não foi mencionada pelo Tribunal Administrativo a não ser pelo fato de impedir a entrada dos não grevistas nos locais de trabalho. Não se fundamentou em atentado ao direito de propriedade do empregador. Estas considerações levam Savatier a concluir que "le grand probleme posé par la pratique de l'occupation des lieux du travail est advantage celui de la conciliation de la liberté de travail des non-grévistes avec le droit de greve que celui des atteintes portées au droit de propriété de l'employer" ${ }^{641}$.

A solução aqui proposta, qual seja, não admitir a intervenção prévia do judiciário para tutelar os direitos e interesses do empregador e alargar o conceito de abusividade para somente considerar ilegítimas, a posteriori, as paralisações que efetivamente causem prejuízo à produção, possibilita a utilização da ocupação da empresa como meio de pressão dos trabalhadores sobre o empregador. Em caso de eventual abuso durante a ocupação, como, por exemplo, situações em que se danificou patrimônio da empresa ou se impediu determinados empregados não grevistas de permanecerem alheios à manifestação, é possível ajuizar o dissídio coletivo pedindo seja reconhecida a ilegitimidade da greve, em tutela antecipada, e, como corolário natural dela, determinada a saída imediata dos trabalhadores. Neste caso, não se estaria diante de uma tutela preventiva na medida em que o movimento já eclodiu e de forma irregular.

Neste particular a solução não distoará tanto daquela adotada na França, em que o empregador tradicionalmente recorre ao procedimento conhecido como référé para obter uma ordem de expulsão dos grevistas que ocupam os locais de trabalho.

Analisando decisões proferidas em procedimentos deste gênero, Bernard Teyssié ressalta a diferença nas soluções adotadas pelos magistrados franceses. Alguns, relativamente pouco numerosos, se recusam a acolher o pedido assinalando que as condições apresentadas pelos artigos 808 e seguintes do nouveau Code de procédure civile

\footnotetext{
${ }^{640}$ Soc. 6 mai 1971, Dr. Soc. 1971, 544 Apud SAVATIER, Jean. Expulsion et licenciement des grévistes occupant des locaux du travail. Droit Social,n. 3, mars 1978, p. 126.

${ }^{641}$ SAVATIER, Jean. Expulsion et licenciement des grévistes occupant des locaux du travail. Droit social,n. 3, mars 1978, p. 126.
} 
não foram preenchidas. Uns apegam-se na falta de urgência ${ }^{642}$, outros acrescentam ao argumento precedente a presença de uma contestação séria ${ }^{643}$.

Outros magistrados após considerar a ocupação dos locais de trabalho ilícita, decidem, conforme a circunstância, esperar, determinar diligências para tentar solucionar pacificamente a questão ${ }^{644}$ e para obter informações seguras sobre a amplitude e origem da greve antes de tomar uma decisão. Eles determinam que um oficial de justiça assegure a colocação e o desenvolvimento de medidas provisórias que ele eventualmente tenha ordenado e a prodecer, demais disso, a pesquisas, visita aos locais de trabalho, consulta a todos os documentos, oitiva de todas as pessoas capazes de esclarecer e relatar a origem e o teor das informações apresentadas, para que ele possa compreender todas as circunstâncias do conflito $^{645}$. O funcionário nomeado para estas providências apresenta a função de trazer informações sobre o fato. Ele fica encarregado de uma missão de conciliação, ao senso comum do termo ${ }^{646}$. Somente se os esforços para uma solução pacífica não lograrem êxito o juge des référés ordenará a expulsão dos ocupantes do local de trabalho ${ }^{647}$.

Para obter a evacuação efetiva dos locais de trabalho e a plena efetividade da medida tomada, a jurisprudência francesa vem entendendo necessária a observância do princípio do contraditório e da ampla defesa. Em algumas circunstâncias já se admitiu que os delegados sindicais ${ }^{648}$ ou representantes eleitos pelos empregados, notadamente chefes de pessoal $^{649}$, representassem na justiça a coletividade dos grevistas. A autoridade

\footnotetext{
${ }^{642}$ TGI Beauvais, réf., 24 oct. 1972: Dr. ouvrier 1973, p. 162, apud TEYSSIÉ, Bernard. Grève dans le secteur privé. Jurisclasseur Travail Traité, fasc. 70-10, 15 avril 2010.

${ }^{643}$ Neste sentido é o precedente TGI Arras, réf., 28 déc. 1965: Dr. ouvrier 1966, p. 125. - TGI Fontainebleau, réf., 20 nov. 1972: Gaz. Pal. 1973, I, 133. - TGI Lille, 30 août 1977: RPDS 1978, p. 59 i apud TEYSSIÉ, Bernard. Grève dans le secteur privé. Jurisclasseur Travail Traité, fasc. 70-10, 15 avril 2010 .

${ }^{644}$ Entendimento adotado nos seguintes precedentes: TGI Bobigny, réf., 12 févr. 1974: D. 1974, jurispr. p. 783, note J.-C. Javillier. - TGI Paris, réf., 22 févr. Et 12 mars 1974: D. 1974, jurispr.. p. 784, note J. -C. Javillier. - TGI Bordeaux, réf., 14 juin 1974, confirme par CA Bordeaux, 10 juill. 1974: Dr. soc. 1975, p. 128, obs. J. Savatier. - TGI Bordeaux, 19 déc. 1977: D. 1978, jurispr.. p. 637, note H. Sinay et G. Wiederkehr. - TGI Privas, réf., 22 juill. 1982: JCP CI 1983, I, 11643, p. 217, n. 8, obs. B. Teyssié. Ibidem.

${ }^{645}$ Neste sentido a decisão TGI Bordeaux, réf., 14 juin 1974, préc. apud TEYSSIÉ, Bernard. Grève dans le secteur privé. Jurisclasseur Travail Traité, fasc. 70-10, 15 avril 2010.

${ }^{646}$ V. TGI Pontoise, réf., 10 févr. 1975: Dr. ouvrier 1975, p. 435. Ibidem.

${ }^{647}$ TGI Bobigny, réf., 8 mars 1974: Dr ouvrier 1975, p. 94. Ibidem.

${ }^{648}$ CA Rennes, 5 juin 1972: JCP G 1973, II, 17327, note H. Goutel; RTD civ. 1973, p. 381, obs. P. Hébraud et P. Raynaud. Ibidem.

${ }^{649}$ Neste sentido foi a decisão proferida no precedente TGI Nevers, réf., 21 mars 1975: D. 1976, jurispr.. p. 266, note J. -P Karaquillo. Ibidem.
} 
exercida, pelos representantes diretos ou indiretos do pessoal sobre a totalidade dos trabalhadores pode ser invocada para apoiar a solução precedente ${ }^{650}$.

Pela proposta de solução apresentada a expulsão poderia sim preceder o contraditório e a ampla defesa por poder ser deferida em sede de tutela antecipada.

\subsection{RESPONSABILIDADE CIVIL DOS SINDICATOS PELO EXERCÍCIO ABUSIVO OU ILEGÍTIMO DO DIREITO DE GREVE}

Jean Pélissier, Alain Supiot e Antoine Jeammaud destacam a delicadeza da situação do magistrado ao se deparar com ação relacionada com o exercício do direito de greve por ser ele, ao mesmo tempo, o garantidor deste direito e o responsável pela limitação de seu exercício e conciliação com o respeito a outros direitos de igual valor. A jurisprudência francesa, segundo os aludidos autores, utiliza dois métodos para solucionar este impasse. Primeiramente analisa a definição jurídica de greve para identificar, entre as manifestações coletivas, quais devem ser juridicamente consideradas greve e quais não merecem este título. Certos movimentos que, por não se enquadrarem como greve, são analisados como falta, são desqualificados já neste momento. O segundo método consiste em debruçar-se não mais sobre a definição, mas sobre o exercício do direito de greve. Em outras palavras, uma vez reconhecido que o movimento coletivo merece a qualificação de greve, o juiz deverá se questionar se houve exercício normal ou anormal deste direito ${ }^{651}$.

É evidente que os prejuízos decorrentes do exercício regular do direito de greve, tanto os sofridos pelo empregador, quanto os sofridos pela coletividade, não são passíveis de ação de indenização posterior. Admitir, por exemplo, a reparação do empregador pelos lucros cessantes correspondentes ao período de paralisação lícita de seus empregados, resultaria inegavelmente no fim do direito de greve.

É forçoso reconhecer, contudo, que as ações nocivas do sindicato, praticadas durante movimento grevista considerado abusivo, ou durante movimento que sequer merece receber a denominação de greve, podem sim ser objeto de reparação civil. Esta

\footnotetext{
${ }^{650}$ No precedente CA Pau, 30 juin 1970. Ibidem.

${ }^{651}$ PÉLISSIER, Jean; SUPIOT, Alain; JEAMMAUD, Antoine. Droit du travail. 21 ed. Paris: Dalloz, 2002, p. 1228/1229.
} 
possibilidade encontra-se expressa no artigo 15 da lei 7883/89 que assevera que a "responsabilidade pelos atos praticados, ilícitos ou crimes cometidos, no curso da greve, será apurada, conforme o caso, segundo a legislação trabalhista, civil ou penal".

Sendo certo que a greve pressupõe sempre algum tipo de prejuízo ao empregador, a responsabilidade civil em caso de declaração da abusividade do movimento paredista deve, naturalmente, se limitar ao excesso, ao que não extrapolar a perda de ganho que seria reputada natural. Neste caso, estar-se-á diante de hipótese enquadrável no artigo 187 do Código Civil vigente, segundo o qual "Também comete ato ilícito o titular de um direito que, ao exercê-lo, excede manifestamente os limites impostos pelo seu fim econômico ou social, pela boa-fé ou pelos bons costumes". A reparação no caso de abuso de direito de greve não deve compreender o ressarcimento dos lucros que o empregador deixou de obter durante a paralisação, mas apenas e tão somente os danos efetivamente comprovados. Um bom exemplo seria o do movimento grevista em que não houve manutenção das atividades necessárias para evitar a deterioração de máquinas e equipamentos do empregador. A greve será naturalmente considerada abusiva. Eventual ação destinada a reparação dos danos causados deverá ter como resultado o ressarcimento do prejuízo que o empregador terá com a compra de novas máquinas ou com a reparação das já existentes, mas não deverá compreender o prejuízo decorrente da falta de vendas ou de produção durante a paralisação, sem prejuízo, naturalmente, de eventual multa pecuniária aplicada em dissídio de greve.

Em texto já publicado, sustentou-se, a partir do conceito de greve previsto no artigo e uma leitura do artigo $2^{\circ}$ da Lei de Greve, que as manifestações deliberadamente violentas, cujas agressões foram decididas coletivamente em assembleia, não deveriam ser reputadas greve abusiva. Elas em verdade não merecem sequer o título de greve. $\mathrm{O}$ fato de neste trabalho se ter proposto uma ampliação no conceito de greve não modifica esta conclusão $^{652}$. Por maior amplitude que se pretenda dar ao conceito de greve ele nunca, jamais poderá dar guarida a atos de violência deliberada. Mantém-se aqui a ideia de que manifestações intencionalmente violentas, em que os trabalhadores, após decisão da assembleia, se dirigem às imediações da empresa armados, com intenções beligerantes, não merecem esse título.

\footnotetext{
${ }^{652}$ Responsabilidade civil dos sindicatos em situações de exercício abusivo do direito de greve e de violência durante a paralisação coletiva. Revista síntese trabalhista e previdenciária, $n$. 269, novembro 2011, p. 54.
} 
Razão assite a Paulo Garcia, ao afirmar que se deve punir toda e qualquer violência contra pessoas e coisas, sendo a lei penal comum bastante para regulamentar a hipótese ${ }^{653}$. O mesmo autor destaca, em outra passagem, que mesmo nas legislações que puniam drasticamente a greve, o picketing pacífico nunca chegou a ser reprimido. Puniam-se, apenas, a violência, mas os organismos sindicais se isentavam de qualquer ação em virtude do fato ${ }^{654}$.

É preciso, contudo, esclarecer o que se entende por manifestação violenta. Excessos cometidos por um ou alguns dos manifestantes geram responsabilidade individual, mas não desvirtuam a natureza do instituto. Resposta violenta à intervenção policial, quando a iniciativa não partiu dos trabalhadores também não.

Como bem salientou Jeanne Goineau, "la faute du gréviste exprime les heurts et malheurs de l'exercice du droit de grève tandis que la faute des syndicats se ressente plus spécifiquement de la configuration de l'exercice du droit syndical"655.

Sempre que a manifestação for violenta, por deliberação coletiva, e, portanto, de greve não se tratar, a parte que se sentir lesada poderá pleitear reparação por todos os danos que lhes foram causados. Neste caso o ente sindical deverá ser responsabilizado pelos danos emergentes e pelos lucros cessantes. Os participantes do movimento deverão ainda responder disciplinarmente perante o seu empregador e criminalmente, conforme seus atos.

Esta é a grande diferença existente entre a hipótese de greve abusiva e a de manifestações violentas, cuja modalidade de ação e os meios empregados foram decididos em assembleia e que, portanto, sequer merecem ser chamadas de greve. Nesta última hipótese, como a ação coletiva não se encontra tutelada pelo direito consagrado constitucionalmente e internacionalmente reconhecido, o empregador deverá também, em ação própria que não o dissídio de greve, ser ressarcido pelos prejuízos decorrentes da inatividade $^{656}$.

\footnotetext{
${ }^{653}$ GARCIA, Paulo. Direito de Greve. Rio de Janeiro: Edições Trabalhistas, 1961, p. 162.

654 Ibidem , p. 160.

655 GOINEAU, Jeanne. La responsabilité civile des grévistes et des syndicats. Droit Social, n. 9-10Septembre-Octobre 1988, p.704-708;

${ }^{656}$ Ideia defendida no seguinte texto: BOUCINHAS FILHO, Jorge Cavalcanti. Responsabilidade civil dos sindicatos em situações de exercício abusivo do direito de greve e de violência durante a paralisação coletiva. Revista síntese trabalhista e previdenciária, n. 269, novembro 2011, p. 60/61.
} 


\section{CONSIDERAÇÕES FINAIS}

Por meio do exercício do direito de greve entrega-se a resolução do conflito coletivo à própria coletividade, conjugando liberdade e participação, dois elementos inerentes ao conceito de cidadania. Embora a greve não seja reconhecida como um direito em todos os países do mundo, naqueles em que ela o é acaba adquirindo singular importância enquanto instrumento de reivindicação de melhoria das condições sociais.

A greve cumpre uma função equilibradora de forças, absolutamente indispensável para que a negociação coletiva seja entabulada em condições próximas ao que se possa imaginar como paridade de armas, possibilitando assim a sempre desejada solução autocompositiva.

Dentro desta concepção funcional, o conflito inerente aos movimentos paredistas não constituem uma patologia, mas um fenômeno natural e, sobretudo, muito necessário. O fato de os movimentos paredistas provocarem inegáveis transtornos para toda a coletividade não pode fazer com que a ideia de autodefesa dos trabalhadores se enfraqueça. Ela precisa, em verdade, ser fortalecida porque a valorização dos movimentos grevistas incrementam o poder de pressão dos trabalhadores, o que, naturalmente, acaba privilegiando as soluções autocompositivas.

Por mais paradoxal que possa parecer, quanto maior o poder de pressão dos trabalhadores, maior será a chance de não haver greve. Em categorias com grande poder de mobilização social, os empregadores tendem a ser mais maleáveis nas negociações por saber dos transtornos que eventual recurso à paralisação coletiva das atividades causar-lheá. Em sentido contrário, a fraqueza da categoria, demonstrada pela dificuldade em estabelecer uma verdadeira concertação e persuadir trabalhadores a paralisarem suas atividades, acaba induzindo o empregador a optar por deixar eclodir o movimento e depois 
endurecer suas propostas para que os grevistas, incapacitados de edificar um instrumento capaz de fazer valer suas necessidades, cedam nas negociações.

As greves não devem, portanto, ser combatidas como uma chaga social. Devem ser juridicamente valorizadas e tuteladas para que se tornem desnecessárias na prática. Toda e qualquer intervenção no conflito resulta no enfraquecimento da ideia de greve enquanto instrumento de pressão eficaz à disposição dos trabalhadores.

Na luta pelo fortalecimento do direito de greve, papel de destaque é atribuído aos órgãos do Poder Judiciário. Sendo certo que a greve surge como fato social, desprovido de maiores regras e que as legislações editadas sobre o tema servem para restringir o seu exercício, há que se enaltecer o papel do intérprete judicial na análise dos movimentos grevistas.

Essa importância se acentua na atual conjuntura político-econômica em que estatísticas apontam para uma tendência de decréscimo no número de greves e locautes, bem como no número de trabalhadores envolvidos e no número de dias não trabalhados por consequência das mesmas. As possíveis razões para essa diminuição são as mais diversas. Menciona-se desde possibilidades positivas, dentre as quais a mitigação do conflito aberto nas relações de trabalho com menor influência da rigidez ideológica na abordagem e resolução dos conflitos, gerando um contexto de maior propensão a negociações coletivas - até outras extremamente nocivas - tais como a redução dos níveis gerais de sindicalização, o menor poder aparente dos sindicatos de trabalhadores, ou mesmo uma provável menor tolerância de consumidores a efeitos de reinvindicações trabalhistas na oferta ou preços de serviços e bens de consumo.

Fato, entretanto é que as mudanças tecnológicas, a globalização, a flexibilização da produção e a reestruturação dos meios de produção inerente a elas impactaram o modo tradicional de fazer greve, provocando o aparecimento de novas modalidades de conflito coletivo e a revitalização de antigas formas atípicas de greve. Como as alterações na legislação trabalhista são sempre demoradas em razão do natural embate entre as bancadas dos trabalhadores e as bancadas dos empregadores, as normas sobre greve não acompanharam as mudanças já verificadas e certamente não acompanharão as que ainda se verificarão. 
A Lei 7.783/89 data de 28 de junho de 1989 e desde então não sofreu uma alteração sequer. O mundo naquela ocasião era completamente diferente. Não havia internet nem comunicação via e-mail, os telefônicos fixos eram comprados com ágil e a forma de fazer uma chamada estando fora de uma residência e de um local de trabalho era utilizando um telefone público. Dificilmente uma lei de greve elaborada para um mundo tão diferente adequar-se-ia com perfeição ao mundo atual.

Cabe aos órgãos do Poder Judiciário se manter atentos a essas mudanças, optando por tentar, a partir de uma interpretação vertical, que tenha como principal premissa o direito de greve consagrado no artigo $9^{\circ}$ da Constituição Federal, não se permitir aplicar a restritiva e antiquada Lei 7.783/89 em sua literalidade. Não se advoga aqui a ideia de desconsiderar a lei por reputá-la inadequada, mas de relê-la de forma a não permitir que ela se torne um óbice ao exercício do direito de greve.

A tese aqui defendida encontra-se alicerçada primeiramente na possibilidade de leitura do artigo $9^{\circ}$ da Constituição de forma a incluir no rol de legitimados para os movimentos grevistas todos os trabalhadores. Enquanto não tiverem a sua situação tutelada por uma legislação própria, os parassubordinados, autônomos, eventuais, estagiários e demais trabalhadores sem vínculo empregatício sujeitar-se-ão aos preceitos da Legislação 7.783/89. Esta solução parte da premissa de que aludidos trabalhadores não podem ser privados de seu direito de greve em razão de uma inércia legislativa ou mesmo de uma opção do legislador infraconstitucional por adotar uma definição de greve mais restritiva do que a que fora consagrada na Carta Magna. Ela se afigura demasiadamente relevante em razão do elevado número de trabalhadores brasileiros que prestam serviços sem vínculo de subordinação.

A leitura proposta para o artigo $9^{\circ}$ da Constituição Federal também restringe a intervenção judicial nos movimentos grevistas a duas hipóteses: para atender as necessidades inadiáveis da comunidade, conforme atividades essenciais definidas em lei que deve ser interpretada restritivamente e para punir abusos cometidos no exercício do direito de greve. $\mathrm{O}$ artigo $9^{\circ}$, segundo essa exegese, assegura de forma ampla o direito de greve, atribuindo à norma infraconstitucional apenas duas tarefas, a de definir os serviços ou atividades essenciais e dispor sobre o atendimento das necessidades inadiáveis da comunidade e a de definir as sanções aplicáveis em caso de exercício abusivo do direito de 
greve. A definição do conceito de abusividade e de suas hipóteses não teria, portanto, sido delegada pelo legislador constituinte para o ordinário, razão pela qual o artigo 14 da Lei 7.783/89 não seria, em uma interpretação literal, compatível com o artigo $9^{\circ}$ da Constituição Federal. A abusividade de determinado movimento grevista, segundo tese que ora se propõe, deverá, quando posta em discussão, ser analisada casuisticamente pelo órgão julgador. A este caberá averiguar a boa-fé objetiva das partes na negociação, observar se a paralisação atingiu a produção da empresa - como é desejável -, e não a sua produtividade, prejudicando a continuidade da atividade econômica após a cessação do movimento, e analisar eventuais excessos do movimento grevista já deflagrado que tenham causado prejuízo desproporcional ao empregador.

A interpretação proposta não despreza o cumprimento das formalidades dispostas na lei 7.783/89, particularmente o pré-aviso, a deliberação por assembleia, o esgotamento das vias negociais e a disposição em ajustar a continuidade das atividades que não podem ser paralisadas. Eles sempre devem ser levados em consideração na análise do órgão judiciário, como demonstração da boa-fé objetiva dos manifestantes. Não devem, contudo, ser analisados como condição sine qua non para que se reconheça a legitimidade do movimento.

A partir deste ponto de vista é possível reconhecer legitimidade a um movimento, ainda que nem todas as formalidades para a deflagração da greve tenham sido observadas, assim como reconhecer validade a manifestações que a princípio não se enquadrariam dentro do conceito mais restrito de greve.

Também se defende a ideia de que a abusividade da greve somente poderá ser identificada após a deflagração do movimento. Não há como pressupor ou presumir que o movimento será abusivo.

Não se pode descartar, por exemplo, a possibilidade de uma greve ser reconhecida abusiva por atingir um bem juridicamente mais relevante do que aqueles por ela tutelados. A solução para este impasse deverá ser casuística e feita a posteriori, ou seja, após a deflagração do movimento. Conquanto não se possa reputar válido modelo que estabeleça, antecipadamente, quais direitos fundamentais deverão se sobrepor aos demais, admite-se, como modelo ilustrativo válido, um que parta de presunção de legitimidade e de validade do movimento grevista, admitindo, em contrapartida, que no caso concreto, após 
deflagrada a greve, em se constatando lesão a outro direito fundamental em decorrência do movimento paredista, seja tomada providência para repará-la.

A partir desta presunção de legitimidade e validade do movimento grevista, é forçoso reconhecer que o movimento grevista só deverá ser considerado abusivo sob a perspectiva da lesão a um direito do consumidor, por exemplo, criando-se óbices para que ele tenha acesso a um serviço determinado por lhe obstar, de alguma forma, o acesso ao estabelecimento empresarial, quando a ação coletiva lhe retirar toda e qualquer possibilidade de ter acesso ao serviço oferecido. Sempre que remanescer alguma possibilidade de obtenção dele, ainda que de forma menos prática e mais desgastante, o movimento deverá ser considerado legítimo.

O legislador definiu greve como a suspensão coletiva, temporária e pacífica, total ou parcial, de prestação pessoal de serviços a empregador. Abriu espaço, portanto, para que se considere ilícita a paralisação da prestação de serviços a quem tecnicamente não é o empregador dos grevistas, mas o cliente de seu empregador formal. Esta interpretação demasiadamente restritiva não pode prosperar. A uma porque em se tratando de trabalhador terceirizado a única forma possível de não atender as determinações do seu empregador é deixando de prestar serviços ao tomador de serviços. A duas porque o entendimento em questão deixaria os empregados de empresa terceirizada sem condições de realizar movimentos grevistas, o que não se coaduna com o que preceitua o artigo $9^{\circ}$ da Constituição da República.

Eventual interferência da paralisação das atividades dos trabalhadores terceirizados na prestação de serviços dos empregados da empresa tomadora de serviços não pode ser reputada violação do direito destes ao trabalho. Se há uma relação de autodependência entre os serviços prestados diretamente pelos seus empregados diretos e aqueles que lhe são prestados por empresas terceirizadas, esta circunstância é fruto da complexa estrutura empresarial escolhida anteriormente. Ao optar por ela, o empresário assumiu um grande risco. Deve, portanto, arcar com o pagamento dos dias em que seus empregados estiveram a sua disposição, mas não puderem trabalhar em razão da paralisação na prestação de serviços por outra empresa.

O empresário poderá, neste caso, romper o contrato que tem com a empresa prestadora de serviços, que, por ser de natureza predominantemente civil, não queda 
suspenso em razão da greve, contratando outra empresa para substituí-la. Ao invés de prejudicar os trabalhadores terceirizados, esta circunstância pode beneficiá-los na medida em que aumenta o seu poder de pressão contra o empregador. Pode ser um sólido argumento para persuadir a empresa prestadora de serviços que os contratou a negociar habitualmente e com bastante transparência e boa-fé.

Assim como a terceirização pode auxiliar os trabalhadores em seu exercício de persuasão do empregador, também a automação e a informatização da produção e da gestão podem, se bem utilizadas, servir ao movimento grevista, na medida em que abrem um novo espaço para a ação conflitiva. Caberá ao judiciário a tarefa de identificar essas situações e, ao invés de declarar a abusividade do movimento por considerá-las atípicas, reconhecer-lhes validade como legítimo instrumento de pressão.

Em situações excepcionais, entretanto, é forçoso reconhecer que, a depender dos bens em jogo e da situação prática, a intervenção se torna indispensável. Essa é a razão pela qual o texto constitucional impõe o atendimento às necessidades inadiáveis da comunidade como principal restrição ao direito de greve.

Analisando a questão sob a perspectiva do direito de ação, há que se reconhecer o ajuizamento de ações que visem coibir excessos ou buscar reparação por danos cometidos durante movimentos paredistas não viola, por si só, o direito de greve. O conteúdo da decisão proferida nestas ações pode, este sim, implicar em injustificável óbice ao direito de greve. Também é forçoso reconhecer que o direito de ação, assim como todos os demais direitos, pode ser exercido de forma abusiva, cabendo aplicação de sanção por litigância de má-fé, quando verificada uma das hipóteses legais.

Há que se reconhecer, também, que o exercício da greve pode sim ser assegurado por provimentos judiciais preventivos. Dentre os muitos exemplos possíveis, cabe mencionar a concessão de liminar para obstar transferência de dirigente sindical que visava enfraquecer movimento grevista, para evitar a substituição de trabalhadores grevistas por outros trabalhadores ou por máquinas, ou para inibir a rescisão contratual dos trabalhadores grevistas. Como não é apenas o empregado que pode valer-se do judiciário para tentar impedir que uma conduta ilícita de outrem venha a causar-lhe danos, há que se reconhecer também ao empregador a prerrogativa de buscar esse tipo de tutela. Também a ele é assegurado o direito de ação. 
Advoga-se a ideia de que cognição judicial deve ser sempre inclinada para a solução asseguradora do exercício do direito de greve. Cria-se, assim uma maior propensão para o deferimento das ações postuladas pelos grevistas e por sua representação para garantir a manifestação e para o indeferimento das ações que visem tutelar direitos em rota de colisão com o direito de greve. Propõe-se aqui uma técnica de exegese segundo a qual sempre que houver dúvida deve-se adotar a solução que melhor assegure o exercício do direito de greve.

Esse desequilíbrio se justifica pela própria natureza conflitiva do direito de greve que o coloca sempre e inevitavelmente em confronto com outros direitos fundamentais. Se não se admitir esse favorecimento hermenêutico ao exercício da greve, e se toda vez que se fizer uma ponderação de valores a opção for pela tutela do direito supostamente ameaçado de lesão, dificilmente sobreviverá um movimento paredista.

A dificuldade para a concessão de tutela preventiva em matéria de greve também decorre da própria natureza do direito em questão. Conquanto a redação do artigo $5^{\circ}$, XXXV da Constituição estatua que a lei não excluirá da apreciação do Poder Judiciário lesão ou ameaça a direito, evidenciando, com clareza solar, a possibilidade de se postular preventivamente para evitar que seu direito venha a ser efetivamente violado, há situações em que a tutela preventiva resta impossibilitada pela própria natureza do direito em confronto com ela. A tese aqui defendida é a de que o direito de greve, tal qual previsto na Constituição, não comporta, em regra, intervenção prévia do Poder Judiciário, a não ser para assegurar o atendimento das necessidades inadiáveis da comunidade, admitindo intervenção posterior para disciplinar os abusos cometidos no curso do movimento grevista. Sob esta perspectiva, o direito de greve não poderia ter o seu âmbito restringido por meio de tutela preventiva, salvo para assegurar o atendimento das necessidades inadiáveis da coletividade e em outras situações de extrema gravidade e rara verificação prática.

A intervenção judiciária nesta discussão acaba quase sempre inibindo a ação direta dos atores sociais. Propugna-se aqui, por essa razão, uma ampla atuação, inclusive com concessão de tutelas preventivas, para assegurar a realização dos movimentos grevistas e uma cautelosa atuação, predominantemente repressiva e excepcionalmente preventiva, quando se tratar de ações que visem tutelar direitos outros em face do direito de greve. A 
ideia é priorizar a ação coletiva uma vez que, como bem observou Philippe Bernoux, “C'est à travers les relations concrètes des acteurs sociaux les uns avec les autres que peut légitimement s'observer et s'analyser le conflit social"657.

Não é isso, contudo, que vem ocorrendo. Analisando-se decisões proferidas em interditos proibitórios, constata-se que, sob o manto de defenderem sua propriedade e seu direito de liberdade e até o direito de ir e vir de seus clientes, os empregadores servem-se do aludido remédio processual para evitar que a greve seja efetivamente exercida, assegurando a continuidade de sua atividade econômica. Algumas determinações feitas nestes procedimentos, obstando a realização de assembleias na frente das empresas, panfletagem, utilização de carro de som etc., atos tipicamente sindicais, constituem manifesto ato antissindical.

Além de servir a um fim impróprio, os interditos proibitórios não deveriam ser admitidos em situações versando direito de greve por diversas razões. Primeiramente por existir um procedimento específico para a solução das lides coletivas entre trabalhadores e empregadores, o dissídio coletivo, de competência funcional do $2^{\circ}$ grau de jurisdição, o que torna, a um só tempo, os juízos monocráticos incompetentes para apreciar demandas em que se discute o direito de greve e o interdito proibitório inadequado enquanto instrumento processual. Em segundo lugar não há justo receio de moléstia à posse vez que a greve não pode ser considerada um ato ilícito e os grevistas não desejam, isto é certo, despojar o empregador da posse da empresa. Em terceiro lugar há que se reconhecer a inadequação do interdito proibitório ao objetivo a que se propõe, também por inadaptabilidade dos seus requisitos às peculiaridades próprias do exercício da greve. Não há, por fim, na maioria dos casos, as alegadas violações ao direito de ir e vir dos clientes, a ameaça de dano à propriedade do empregador e a aludida violação ao direito ao trabalho dos não grevistas.

O que se chama de violação ao direito de ir e vir do consumidor não passa, na verdade de uma tentativa de assegurar que este continue tendo acesso ao serviço como se greve não existisse. Na maioria das greves não há o alegado direito ao trabalho dos não grevistas, apenas uma reação natural e imediata às estratégias empresariais de coagir economicamente os ocupantes de cargo de confiança a não aderir aos movimentos

\footnotetext{
${ }^{657}$ BERNOUX, Philippe. Le modele français de déclenchement des greves. Droit social, n. 9-10, SeptembreOctobre 1988, p. 629.
} 
paredistas. A tutela ao direito do empregador de manter a posse sobre seus estabelecimentos não passa, na verdade, de uma tutela da atividade empresarial.

Não fosse isso o bastante, as alegações são feitas antes que o movimento efetivamente ecloda, não passando, portanto, de meras suposições.

A solução, portanto, para os empregadores é ajuizar, tão logo deflagrado o movimento paredista, o dissídio coletivo de greve. Se houver efetiva colisão entre o direito de greve e algum outro direito fundamental poderão eles, a qualquer tempo, requerer a antecipação da tutela para que a greve seja declarada abusiva desde logo, e determinada a cessação do movimento sob pena de multa.

Os órgãos que integram o judiciário também exercem importante papel na afirmação das garantias ao exercício do direito de greve, cabendo-lhes determinar a reintegração dos grevistas dispensados enquanto o seu contrato se encontrava suspenso em razão da adesão ao movimento grevista, determinar tutela inibitória para impedir a substituição dos trabalhadores grevistas por outros ou por máquinas, conceder liminar destinada a impedir a transferência determinada pelo empregador, além de qualquer outra medida que vise assegurar o exercício do direito de greve pelo trabalhador, e sancionar condutas antissindicais praticadas pelo empregador.

As propostas apresentadas ao longo deste trabalho primam pelo livre exercício do direito de greve. Objetiva-se, com elas, encontrar caminhos para sempre possibilitar que o movimento se consolide, assegurando aos trabalhadores poder de pressão sobre o empregador na expectativa de que, a partir dos resultados obtidos, as paralisações se tornem desnecessárias nos anos seguintes por terem as partes conseguido alcançar uma solução autocompositiva sem precisar de novo recurso ao mecanismo de autotutela. 


\section{REFERENCIAS}

ANDRADE, Everaldo Gaspar Lopes de. Dissídio coletivo. São Paulo: LTr, 1993;

ARENHART, Sérgio Cruz. A tutela inibitória da vida privada. São Paulo: RT, 2000, p. 143 ;

AROUCA, José Carlos. O sindicato em um mundo globalizado. São Paulo: LTr, 2003;

ARTEAGA, William Thayer e FUENZALIDA, Patricio Novoa. Manual de derecho del trabalho, tomo I, Generalidades, Derecho Colectivo del trabajo. $5^{\text {a }}$ edición. Santiago: 2007;

BARTOLOMEI DE LA CRUZ, Héctor; POTOBSKY, Geraldo von; SWEPSTON, Lee. The Internacional Labor Organization: The Internacional Standards. WestviewPress: Oxford, 1996;

BASURKO, Olga Fotinopoulou. El asunto Viking Line: um litigio que va más allá de la encrucijada entre las libertades económicas comunitárias y el derecho a la huelga. Tribuna Social Revista de Seguridad Social y laboral, n. 217, 2009, págs. 40-58;

BASURKO, Olga Fotinopoulou. Las Responsabilidade del sindicato em huelgas transnacionales (segunda y última parte). Tribuna Social: Revista de SEguridad Social y laboral, n. 239, 2010, p. 39-47;

BATALHA, Wilson de Souza Campos. Sindicatos, sindicalismo. São Paulo: LTr, 1992; Tratado de direito judiciário do trabalho. São Paulo: LTr, 1985;

BAYLOS GRAU, Antonio. Estado democrático de derecho y amplio reconocimiento del derecho de huelga. Derecho laboral - tomo LIV, n. 242, abril-junio 2011, p. 285-292;

BELTRAN, Ari Possidônio. A autotutela nas relações do trabalho. São Paulo: LTr, 1996; 
BÉRAUD, Jean-Marc. Le rôle des délégués em cours de grève. Droit social, n. 9-10, Septembre-Octobre 1988, p. 666-671;

BERNOUX, Philippe. Le modele français de déclenchement des greves. Droit social, n. 910, Septembre-Octobre 1988, p. 624-629;

BOUCINHAS FILHO, Jorge Cavalcanti. A atual dimensão do debate sobre o ajuizamento do dissídio coletivo de comum acordo. A tese da inconstitucionalidade da exigência do impulso bilateral. Jus Navigandi, Teresina, ano 13, n. 1792, 28 maio 2008. Disponível em: <http://jus.com.br/revista/texto/11315>. Acesso em: 28 dez. 2011;

Discriminação por sobrequalificação. São

Paulo: LTr, 2009;

- Responsabilidade civil dos sindicatos em situações de exercício abusivo do direito de greve e de violência durante a paralisação coletiva. Revista Síntese Trabalhista e Previdenciária, n. 269, novembro 2011, p. 51-61.

BOURGOIGNIE, Thierry. Élements pour une theórie du droit de la consummation. Bruxelles: Story scientie, 1988.

CARVALHO, Augusto Cesar Leire de. Direito fundamental de greve e interdito proibitório. In: ARRUDA, Kária Magalhães; COSTA, Walmir Oliveira da (coordenadores). Direitos coletivos do trabalho na visão do TST: homenagem ao Ministro Rider Nogueira de Brito. São Paulo: LTr, 2011, p. 13-36.

CASTAN, Vitor Manoel. Abuso de direito sindical. São Paulo: LTr, 2009;

CASTRO, Antonio Escosteguy. Trabalho, tecnologia e globalização: a necessidade de uma reforma sindical no Brasil. São Paulo: LTr, 2006;

CERDEIRA, Eduardo de Oliveira. Ações coletivas e a substituição processual pelos sindicatos. São Paulo: LTr, 2010; 
CORREIA, Marcus Orione Gonçalves. Teoria e prática do poder de ação na defesa dos direitos sociais. São Paulo: LTr, 2002;

CORSO, Fulvio. Il diritto sindacale. Torino: Giappichelli Editore, 2008;

CORTEZ, Julpiano Chaves. A lei de greve. São Paulo: LTr, 2010;

COUTINHO, Grijalbo Fernandes. Problemas atuais e perspectivas para o mundo do trabalho. In: PAIXÃO, Cristiano; RODRIGUES, Douglas Alencar; CALDAS, Roberto de Figueiredo (coords.). Os novos horizontes do direito do trabalho: homenagem ao ministro José Luciano de Castilho Pereira. São Paulo: LTr, 2005, p. 303-335;

Terceirização bancária no Brasil: direitos humanos violados pelo Banco Central. São Paulo: LTr, 2011;

CRIVELLI, Ericson. Direito internacional do trabalho contemporâneo. São Paulo: LTr, 2010;

CRIVELLI, Ericson. Interditos proibitórios versus liberdade sindical - uma visão panorâmica do direito brasileiro e uma abordagem do direito internacional do trabalho. Revista LTr. 73-12/1427.

DINAMARCO, Candido Rangel. Execução civil. $5^{\text {a }}$ Ed. São Paulo: Malheiros, 1997;

DUARTE, Ronnie Preuss. Garantia de acesso à Justiça: os direitos processuais fundamentais. Coimbra: Coimbra Editora, 2007;

DUARTE NETO, Bento Herculano. Direito de greve: aspectos genéricos e legislação brasileira. São Paulo: LTr, 1992;

ERMIDA URIARTE, Oscar. A flexibilidade. São Paulo: LTr, 2002;

Apuntes sobre la huelga. $2^{\mathrm{a}}$ ed. Fundación de cultura universitária. Montevideo: 1996, p. 9/10; 
. Critica de la libertad sindical. Derecho Laboral - Tomo IV, n. 242, abril-junio 2011, p. 225-253;

FERREIRA, Mônica Brandão. O dissídio coletivo na Justiça do Trabalho: da necessidade do comum acordo para o seu ajuizamento. Revista LTr, volume 71, n 01, Janeiro de 2007;

FIGUEIREDO, Dias. O direito de greve dos bombeiros do Rio de Janeiro e a liberdade nossa de cada dia. Brasil de fato: uma visão popular do Brasil e do Mundo. Disponível em: <http://www.brasildefato.com.br/node/6525>, Acesso em 28/12/11

FONTANELLA, Denise et ali. O lado (des) humano da terceirização: o impacto da terceirização nas empresas, nas pessoas e como administra-lo. Salvador-BA: Casa a qualidade, 1995;

FREITAS JÚNIOR, Antonio Rodrigues de. Conflitos de justiça e direito do trabalho: alcance e possibilidades para o emprego da mediação. In: BOUCINHAS FILHO, Jorge Cavalcanti; PEREIRA, Luciano de Castilho e FAVA, Marcos Neves (org). O direito material e processual do trabalho dos novos tempos: estudos em homenagem ao Professor Estêvão Mallet. São Paulo: LTr, 2009, p. 50-63;

. Conteúdo dos pactos sociais. São Paulo:

LTr, 1993;

- Direito do trabalho na era do desemprego: instrumentos jurídicos em políticas públicas de fomento à ocupação. São Paulo: LTr, 1999;

- Novas perspectivas para o Direito

Coletivo do Trabalho no Brasil (ou sobre a premência da disciplina legal da conduta antissindical). Revista do Advogado, ano XXX, n. 110, Dezembro de 2010, p. 17-23. 
Sindicato: domesticação e ruptura: um estudo da representação sindical no direito brasileiro. São Paulo: Ordem dos Advogados do Brasil, Departamento Editorial, 1989;

FREITAS JÚNIOR. Antonio Rodrigues de; MERINO, Lucyla Tellez. Horizontes para o direito numa sociedade em mudança: dilemas da Alca, Impasses do Mercosul e Crise do Estado-Nação como Círculo Retroalimentador. São Paulo: LTr, 2004;

FROSSARD, Joseph. Les obstacles juridiques au déclenchement des greves. Droit Social, n. 9-10, septembre-octobre 1988, p. 630-638;

GALANTINO, Luisa. Diritto sindacale. Torino: Giappichelli Editori, 2009;

GALLO, Ettore. Sciopero e repressione penale. Bologna: Societè editrice Mulino Bologna, 1981;

GARCIA, Paulo. Direito de greve. Rio de janeiro: Edições Trabalhistas, 1961;

GARCIA NINET, José Ignacio e SALIDO BANÚS, José Luis. La huelga.In: GARCIA NINET, J. Ignacio(dir) e VICENTE PALACIO, Arántzazu. Derecho del Trabajo. $5^{\text {a }}$ Edición.Pamplona: Thomson Reuters, 2009, p.789-816;

GRAU, Antonio Baylos. Estado Democrático de Derecho y amplio reconocimiento del derecho de huelga. Derecho laboral - Tomo LIV, n. 242, abril-junio 2011, p. 285-292;

GEHRKE, Luís Carlos. Função social da posse e da tutela possessória em regiões fronteiriças do MERCOSUL. 116 fl. Dissertação (mestrado em Integração LatinoAmericana).Universidade Federal de Santa Maria. 2008;

GIUGNI, Gino. Diritto sindacale. Aggiornato da Lauralba Bellardi, Pietro Cursio e Mario Giovanni Garofalo. Bari: Cacucci Editore, 2010;

GOINEAU, Jeanne. La responsabilité civile des grévistes et des syndicats. Droit Social, n. 9-10-Septembre-Octobre 1988, p.702-708; 
LYON-CAEN, Gerard. Réglementer le droit de grève. Droit Social, n.9-10, septembreoctobre 1988, p. 709-712.

MAGANO, Octávio Bueno; MALLET, Estêvão. O direito do trabalho na constituição. Rio de Janeiro: Forense, 1993;

MAIA, Diogo Campos Medina. Ação coletiva passiva. Rio de Janeiro: Editora Lumen Juris, 2009;

MAIOR, Jorge Luiz Souto. Curso de direito do trabalho: a relação de emprego, volume II. São Paulo: LTr, 2008;

Fundamentos para a solução dos conflitos coletivos de greve. In: MAIOR, Jorge Luiz Souto e CORREIA, Marcus Orione Gonçalves. Curso de Direito do Trabalho, vol. III, Direito coletivo do trabalho. São Paulo: LTr, 2008;

. O direito de exercer o direito de greve. In: THOMÉ, Candy Florêncio e SCHWARZ, Rodrigo Garcia. Direito coletivo do trabalho: curso de revisão e atualização. Rio de Janeiro: Elsevier, 2010, p. 255-258;

MAISTRO JUNIOR, Gilberto Carlos. O Código de Defesa do Consumidor como principal fonte subsidiária diante das lacunas na legislação trabalhista. Revista Bonijuris, abril 2011, ano XXIII, n. 569, v. 23, n.4.

MALLET, Estêvão. A atencipação da tutela no processo do trabalho. $2^{\mathrm{a}}$ ed. São Paulo: LTR, 1999;

MARTINEZ, Luciano. Curso de direito do trabalho: relações individuais, sindicais $e$ coletivas do trabalho. São Paulo: Saraiva, 2010, p. 603.

MARTINON, Arnaud; LECONTE, Fabienne; TARAUD, Isabelle. Réquisitionner?Revue de droit du travail, Editions Dalloz 2011, p. 9; 
MELO, Raimundo Simão de. A greve no direito brasileiro. São Paulo: LTr, 2006;

MENDONÇA, Gentil. A interpretação no direito do trabalho. São Paulo: LTr, 1978;

MORAES, Márcio André Medeiros. A responsabilidade civil do sindicato perante o consumidor. 2001. 377 f. Tese (doutorado em Direito das Relações Sociais - Direito Civil). Pontíficia Universidade Católica de São Paulo, São Paulo, 2001;

MORAES FILHO, Evaristo de. Do delito ao direito de greve - um quarto de século na vida italiana. Rio de Janeiro: Serviço de documentação do M. T. I. C., 1956;

NASCIMENTO, Amauri Mascaro. Compêndio de direito sindical. $4^{\mathrm{a}}$ ed. São Paulo: LTr, 2005 ;

NASCIMENTO, Amauri Mascaro. Direito do trabalho na Constituição de 1988. $2^{a}$ edição. São Paulo: Saraiva, 1991;

NOGUER, Héctor Humenes. Derecho del trabajo y de la seguridad social, tomo II: derecho colectivo del trabajo. $17^{\mathrm{a}} \mathrm{ed}$. Santiago: 2005 ;

OLIVEIRA, Paulo Eduardo Vieira de. Negociação coletiva. In: MAIOR, Jorge Luiz Souto e CORREIA, Marcus Orione Gonçalves. Curso de direito do trabalho, volume 3: direito coletivo do trabalho. São Paulo: LTr, 2008, p. 108-127;

ORGANIZAÇÃO INTERNACIONAL DO TRABALHO. A greve: $o$ direito $e a$ flexibilidade. Brasília: Organização Internacional do Trabalho, 2002;

ORGANIZAÇÃO INTERNACIONAL DO TRABALHO. El comité de libertad syndical: impacto desde su creación. Genebra: Oficina Internacional del Trabajo, 2001;

ORLANDINI, Giovanni. Sciopero e servizi pubblici essenciali nel processo d'integrazione europea: uno Studio di diritto comparato e comunitário. Torino: Giappichelli editore: 2003; 
PÉLISSIER, Jean; SUPIOT, Alain; JEAMMAUD, Antointe. Droit du Travail. 21 ed. Paris: DAlloz, 2002;

PÉREZ DEL CASTILLO, Santiago. O direito de greve. São Paulo: LTr, 1994;

RAY, Jean-Emmanuel. Le juge et les conflits collectifs de travail. Droit Social, n. 7-8 Juillet-Août 1986, p. 617-623;

ROCHA, Cláudio Jannotti da. Dissídio Coletivo: uma forma efetiva de acesso à Justiça. In: KOURY, Luiz Ronan Neves; FERNANDES, Nadia Soraggi e CARVALHO, Ricardo Wagner Rodrigues de (coord). Tendências do processo do trabalho. São Paulo: LTR, 2010 ;

RODIÈRE, Pierre. Les arrêts Viking et Laval, le droit de grève et le droit de négociation collective. Revue trimestrielle de droit européen, 2008, n. 1, p. 47;

ROMAR, Carla Teresa Martins. Nova competência da Justiça do Trabalho fixada pela Emenda Constitucional n. 45, de 2004 - análise dos incisos II, III e IV do art. 114 da Constituição Federal. In: MANUS, Pedro Paulo Teixeira; ROMAR, Carla Teresa Martins; GITELMAN, Suely Ester. Competência da justiça do trabalho e EC n. 45/2004. São Paulo: Atlas, 2006, p. 37-38;

RUSCIANO, Mario. Diritto di sciopero e assetto costituzionale. Rivista italiana di diritto del lavoro, 2009, I. G, p. 49-69;

SALVAGE, Philippe. Les attributions du délégué syndical em cas de grève. Droit Social, n. 7/8, Juillet-Août 1986, p. 624-634

SANTORO-PASSARELLI, Giuseppe. Diritto sindacale. Bari: Editori Laterza, 2009;

SANTOS, Ronaldo Lima dos. Interditos proibitórios e direito fundamental de greve. Revista Síntese trabalhista e previdenciária, n. 261, março de 2011, p. 73; 
- Sindicatos e ações coletivas: acesso à justiça coletiva e tutela dos interesses difusos, coletivos e individuais homogêneos. $2^{\mathrm{a}}$ ed. São Paulo: LTr, 2008, p. 284/285;

SAVATIER, Jean. Expulsion et licenciement des grévistes occupant des locaux du travail. Droit social, n. 3, mars 1978, pp. 217-225;

SEGUEL, Alejandro Romero. Curso de derecho procesal civil, tomo I: La acción y La protección de los derechos. Santiago: Editorial Jurídica de Chile;

SILVA, Homero Mateus Batista da. Curso de direito do trabalho aplicado, vol. 7: direito coletivo do trabalho. Rio de Janeiro: Elsevier, 2010;

SILVA, Otávio Pinto e. A contratação coletiva como fonte do direito do trabalho. São Paulo: LTr, 1998;

SOUZA, Ronald Amorim e. Greve \& Locaute. São Paulo: LTr, 2007;

STROPPA, Tatiana. As dimensões constitucionais do direito de informação e o exercício da liberdade de informação jornalística. Belo Horizonte: Editora Fórum, 2010;

TEYSSIÉ, Bernard. Grève dans le secteur privé. Jurisclasseur Travail Traité, fasc. 70-10, 15 avril 2010;

VACCA, Michele. Il diritto di sciopero e le sue limitazioni nelle organizzaioni e Nei paesi europei. Milano: Giuffrè Editore: 1983;

VALTICOS, Nicolas. Droit international du travail. In: CAMERLYNCK, G. H. Traité de droit du travail.Paris: Dalloz, 1970;

VARGAS, Luiz Alberto de; FRAGA, Ricardo Carvalho. Relações Coletivas e Sindicais Nova Competência após a EC. 45. In: COUTINHO, Grijalbo Fernandes; FAVA, Marcos Neves. Justiça do Trabalho: Competência ampliada. São Paulo: LTr, 2005, p. 331-344; 
VEIGA, Aluysio Corrêa da Veiga. O Direito de greve e o interdito proibitório. In: BOUCINHAS FILHO, Jorge Cavalcanti; PEREIRA, José Luciano de Castilho; FAVA, Marcos Neves. O direito material e processual do trabalho dos Novos Tempos: estudos em homenagem ao Professor Estêvão Mallet. LTr, 2009, p. 25-49;

VIANA, Márcio Túlio. Direito de resistência: possibilidades de autodefesa do empregado em face do empregador. São Paulo: LTr, 1996;

VILLEGAS, Aldo Zela. La tutela preventiva de los derechos: como manifestación de la tutela diferenciada. Lima: Palestra Editores, 2008;

ZOLA, Émile. Germinal. Ebook. Maio, 2004; 


\section{BIBLIOGRAFIA CONSULTADA}

ALEMÃO, Ivan. $O A B$ e sindicatos: importância da filiação corporativa no mercado. São Paulo: LTr, 2009;

ANNONI, Danielle. O direito humano de acesso à justiça no Brasil. Porto Alegre: Sergio Antonio Fabris Editor, 2008;

ARRUDA, Hélio Mário de. Oliveira Vianna e a legislação do trabalho no Brasil. São Paulo: LTr, 2007;

BRANCO, Ana Paula Tauceda. A colisão de princípios constitucionais no Direito do Trabalho. São Paulo: LTr, 2007;

BRISSY, Stéphane. Le droit et la violence au travail. Revue de Droit du Travail, septembre 2010, p. 499-506;

CAPALDI, Nicholas. Da liberdade de expressão. Rio de Janeiro: Fundação Getúlio Vargas, 1974;

CERNOV, Zênia. Greve de servidores públicos. São Paulo: LTr, 2011;

CONTRERAS, Guido Macchiavello. Derecho colectivo del trabajo: teoria y análisis de sus normas. Santiago: Editorial Jurídica de Chile, 1989;

DÉPREZ, Jean. L'évolution de la jurisprudence sur l'existence de revendications préalables non satisfaites. Droit Social, n.9-10, Septembre-Octobre 1988, p. 646-650;

L'existence de revendications professionnelles préalables, condition de licéité de la grève. Droit Social, n. 7-8, Juillet-Août 1986, p. 610-616;

DUPEYROUX, J.J. Les juridictions sociales dans la reforme judiciaire. Droit Social, n. 3, mars 1960, p. 153-161; 
DUQUESNE, François. Les emplois-jeunes et la grève. Droit Social, n. 7/8, Juillet-Août 2001, p. 711-714;

FISCHER, Desmond. O direito de comunicar: expressão, informação e liberdade. Brasília: Editora Brasiliense, 1982;

GARCIA, Maria. Desobediência civil: direito fundamental. $2^{\mathrm{a}}$ edição. São Paulo: RT, 2004;

GOMES, Orlando. A convenção coletiva de trabalho. São Paulo: LTr, 1995;

GOMES JÚNIOR, Luiz Manoel; CHUEIRI, Miriam Fecchio. Direito de imprensa $e$ liberdade de expressão: soluções teóricas e práticas após a revogação da Lei 5.250, de 09.02.1967. São Paulo: RT, 2011;

GONÇALVES, Lilian. Ultratividade das cláusulas normativas. São Paulo: LTr, 2008;

HINZ, Henrique Macedo. Cláusulas normativas de adaptação. São Paulo: Saraiva, 2007;

LAURIA, Francesco; STEFANOVICHJ, Silvia. A tu per tu con il sindicato: dialoghi di relazioni sindacali e di lavoro. Roma: Giuffrè Editore, 2010;

LE CHATELIER, Gilles. Règlement intérieur et droit de grève. Droit social, n. 2, février, 1993, p. 162-164;

LOKIEC, Pascal. Le droit de grève au Royaume-Uni après les arrêts Demir et Enerji Yapi Yol Sen. Revue de droit du travail 2011, p. 665.

MAGANO, Octávio Bueno. Manual de direito do trabalho, v. 3, direito coletivo do trabalho. $2^{\mathrm{a}}$ edição. São Paulo: LTr, 1990:

MELLO, Lais Corrêa de. Liberdade sindical na constituição brasileira. São Paulo: Saraiva, 2005; 
NOJIRI, Sérgio. O dever de fundamentar as decisões judiciais. São Paulo: Editora Revista dos Tribunais, 1999;

OLIVEIRA, Fernando Alves de. S.O.S Sindical PT: o que os contribuintes dos sindicatos e a sociedade precisam saber sobre o sindicalismo brasileiro e suas graves contradições. São Paulo: LTr, 2009;

OFICINA INTERNACIONAL DEL TRABAJO. La libertad de asociación y la libertad sindical en la práctica: lecciones extraídas: informe global com arreglo al seguimento de la Declaración de la OIT relativa a los princípios y derechos fundamentales en el trabajo 2008. Ginebra: Oficina Internacional del Trabajo, 2008.

RADÉ, Christophe. La solitude du gréviste. Droit social, n.4 avril 1997, p. 368-375;

. Le juge des référés et la réquisition des grévistes. Droit social, $n$. 6 , juin 2003, p. 621-624;

RAY, Jean-Emmanuel. Dualisme juridictionnel et licenciement d'um représentant du personnel gréviste (À propos de l'arrêt Moreau, Conseil d'Etat 1er avril 1992). Droit social, n.1, janvier 1993, p.51.

RIVERO, Jean. Les greves d'août 1953 et l'evolution du droit de grève des agents publics. Droit social, 1951, p. 517-526

ROMITA, Arion Sayão(coord). Sindicalismo. São Paulo: LTr, 1986;

ROMITA, Arion Sayão. Sindicalismos, economia, estado democrático: estudos. São Paulo: LTr, 1993;

RUPRECHT, Alfredo. Conflitos coletivos de trabalho. São Paulo: LTr, 1979;

SANTOS, Enoque Ribeiro dos. Direitos Humanos na Negociação Coletiva: Teoria e Prática Jurisprudencial. São Paulo: LTr, 2004. 
SANTOS, Ronaldo Lima dos. Teoria das normas coletivas. São Paulo: LTr, 2007;

SARATT, Newton Dorneles; SOUTO, Carlos Fernando e LEIRIA, Jerônimo Souto. $O$ contrato coletivo de trabalho. Porto Alegre: L\&PM, 1993;

SAVATIER, Jean. L'occupation des lieux du travail. Droit social, n.9-10, SeptembreOctobre 1988, p. 655;

SILVA, Antônio Álvares da. Greve no serviço público depois da Decisão do STF. São Paulo: LTr, 2008;

Pequeno Tratado da nova competência trabalhista. São

Paulo: LTr, 2005;

SPADONI, Joaquim Felipe. Ação inibitória: a ação preventiva prevista no art. 461 do CPC. $2^{a}$ ed. São Paulo: Editora Revista dos Tribunais, 2007;

TEODORO, Maria Cecília Máximo. O princípio da adequação setorial negociada no direito do Trabalho. São Paulo: LTr, 2007;

VASCONCELOS FILHO, Oton de Albuquerque. Liberdades sindicais e atos antisindicais: a dogmática jurídica e a doutrina da OIT no contexto das lutas emancipatórias contemporâneas. São Paulo: LTr, 2008;

VERKINDT, Pierre-Yves. Vivre dignement de son travail: entre salaire et revenu garanti. Droit social, n.1, janvier 2011, p. 18-23;

VILHENA, Paulo Emílio Ribeiro de. Da sentença normativa à luz da Emenda Constitucional 45/04. São Paulo: LTr, 2006. 